University of Louisville

ThinkIR: The University of Louisville's Institutional Repository

Electronic Theses and Dissertations

$5-1946$

\title{
The problem of the chronically ill in Louisville, Kentucky, 1946.
}

Dinard S. Carr

University of Louisville

Follow this and additional works at: https://ir.library.louisville.edu/etd

Part of the Social Work Commons

\section{Recommended Citation}

Carr, Dinard S., "The problem of the chronically ill in Louisville, Kentucky, 1946." (1946). Electronic Theses and Dissertations. Paper 1874.

https://doi.org/10.18297/etd/1874

This Master's Thesis is brought to you for free and open access by ThinkIR: The University of Louisville's Institutional Repository. It has been accepted for inclusion in Electronic Theses and Dissertations by an authorized administrator of ThinkIR: The University of Louisville's Institutional Repository. This title appears here courtesy of the author, who has retained all other copyrights. For more information, please contact thinkir@louisville.edu. 


\title{
UNIVERSTPY OF LOUISVILLE
}

THE PROBLDM OF ITE CERONICALIY ILL IN

$$
\text { LOUISVILLE, KIINTUCKY, } 1946
$$

\author{
A DISSERTAT ION \\ SUBMIITED TO THE FACULTY \\ OF THE RAMOND A KENT SCHOOL OF SOCIAL WORK \\ In Partial Fulfillment of the \\ Requirements for the Degree \\ Of Master of science in Social Work
}

By

Dinard S. Carr

1946 


\section{NAME OF STUDENT: DInard s. Carr}

TITLE OF TThSIS: The Problem of the Chronically III in Louisville, Kentucky, 1946

APPROVAD BY READINT CONRITTES CORPOSED OF THE

FOLLOWING MEIBERS:

NAME OF DIRECTOR: TOhn J. Cronin

DATE: May 29, 1946 
THE PROBLEM OF THE CHRONICALLY III IN IOTISVILIE, KENTUCKY, 1946 
TABLE OF CONTENTS

Page

IIST OF TABLTS ....................

INTRODUCTION . . . . . . . . . . . . ... 2

CEAPTER I. CTRONIC DISEASE: A COMTTNITY PROEL :. . . . . II

CHAPTER II. THE SIUDY OF LOUISVIIIE GENERAI IOSPITAI

PATIHNTS .................. 37

1927 study .................. 38

1837 study .................. 42

1945 study . . . . . . . . . . . . . 47

Method of present study . . . . . . . .. . 49

The number of chronically 111 . . . . . . . 56

Sex and race................ 57

Age ..................... 59

Martit status................. 60

Dilagnoses................... 67

Condition ................ . . 77

Prognosis .................. 78

Duration of 1llness ............. 81

Hospital admissions............ 83

Cost of care................. . 86

Patients contribution towards the cost of care.. 87

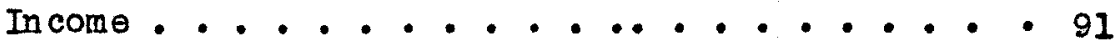

Occupation ................ 93

Housing . . . . . . . . . . . . . . 99

Medical care in the hospital . . . . . . 103

Clinics................. . 105

Medical care recommended . . . . . . . 107

Patients plans for medical care....... . 108

Patients known to social service........ 115

CHAPTER III. CONMUNITY RESOURCES FOR MEETING TTE NEEDS OF

TLE CTRONICALLY ILI. . . . . . . . . . . 125

Home care:

1. medical . . . . . . . . . 125

alinics............... . 125

city physiclans............ . 126

nursing . . . . . . . . . . . 127

2. other .............. 131

housekeep ing aides . . . . . . . . 131

soc lal agencies... . . . . . . . 133

insurance . . . . . . . . .. 136

vocational rehabilitation . . . . . 139

sheltered work. . . . . . . . ... 140

3. chronically ill children in their own hames;

schools .............. 145

4. foster homes............. 147 
Nurs ing Homes . . . . . . . . . 147

Institutions:

1. municipal ......... 157

Home $f \alpha$ the Aged and Infirm . . . 159

Jefferson County Home for the Aged. . . 173

2. Benerolent institutions ....... 175

Ho spitals :

1. Kings Daughters Home for Incurables . 180

2. Crippled children . . . . . . . 182

3. Ch1laren W1 th rheumatic ferer . . . 184

4. Louisville General Hospital . . . . 185

5. Chronic Ho spitals . . . . . . 190 standards of chronic hospital care. 196 nursing . . . . . . . . . 204 occupational therapy ...... 205 physical therapy ........ 206 medical social service...... 207

Prevention ............. 212

Federal participation ... . . . . . 215

CONCLUSIONS AND RECOMHNDATIONS . . . . . . . . 221

BIBLIOGRAPLY . . . . . . . . . . . . . . 228

APPENDIX

1. Copy of schedule used in the present stuay ..... 235

2. Description of Hontefiore Hospitel and the Chronic

Disease Hospital on Welfare Island, New York . . . 238

3. Copy of letter used in the present study ...... 244

4. Copy of application for permit to operate a

nursing home .................. 247 
Table 1. Ghronic Cases Reported as Living in Om Homes, Teaporarily in General Hospital, and Institutions for Long THme Care, Louisville, Kent ucky, 1837 ...........44

Table 2. Chronically Ill Patients Admitted to Lou isville Ceneral Hospital February 5th Through February 14th, 1946, by dagnosis and Percent......................... 54

Table 3. Chlef Disease Croups of Chronically nll Patients Admitted to Louisville Ceneral Howital February 5th Through February 14th, 1946, by Race............. 58

Table 4. Ocoupation of Chronically $I 1$ Pationts Admitted to Louistile General Hospitel February 5th Through February 14 th, 1946, by Bace...................

Table 5. Age of Chronically Ill Patients Admitted to Louisv1lle General Hos pital February 5th Through February 14th, 1946, by Sex, Race, and Wartial status........

Table 6. Martial status of Chronically Ill Pat lents Admitted to Louis ville Coneral Hospital February 5th Through Fobruary 14th, 1946, by Sex.....................

Table 7. Hove ing of Chronically IIl Patients Admitted to Ioulsville General Hospitel February 5th Through February 14th, 1946, by Number in Hous ohold and number of children.

Table 8. Housing of Chronically Ill Patient Admitted to Louis ville General Has pital February 5th Through 14th, 1946, by Number of Rooms, whether Room to Self, sleeping alone.........................

Table 9. Diagnos is of Patients in The Psych latric Wards Admitted to Louis ville General Hospital February 5th Through February 14th, 1946, by Conditicn, Prognos is, and Dispositi on .................................

Table 10. Chief Disease Groups of Chronically Ill Patients Admitted to Louisville Generel Hospital Fobruary 5th Through February 14th, 1946, by Number of Previous Admiss lons.................................... 1

Table 11. Chlef Disease Graups of Chronically Ill Patients damitted to Louls vilis Ceneral Hospital Februery 4th Through February 14th, 1946, by Durati on of IIIness....72

Table 12. Chlef Disease Groups of Chronicelly Ill Patients Admitted to Loulsville Ceneral Eospital Pobruary 5th Through February 14th, 1946, by condition.............76 
Table 13. Chief Disease Groups of Chronically Ill Patients Admitted to Loularille General Hospital February 5 th Through February 14th, 1846, by Prognosis of Patiente on Ward at Time of Study..............80

Teble 14. Previous Admissions to other Hospitals, Nurs ing Homes, am Instituticns of Chronically III Patients Admitted to Louisville Ceneral Hosp1tal February 5th Through February 14th, 1946,.... 84

Table 15. Number of Previcus Admiasions of Chronically Ill Patient s Admitted to Io uf 8ville General Hospital February 5th Through February 14th, 1946, by Total Hosp Ital Days Per Patient................ 85

Table 16. Monthly Income of Chronically Ill Patients Admitted to Loulsville Ceneral Hogp 1 tel February 5 th Through February 14th, 1946, by Ward and Hospital Cleselfieation, $A, B$, or C....................... 88

Table 17. Source of Income of Chronically Ill Patients Admitted to Louf orille Ceneral Bospitel Fobruary 5th Through February 14th, 1946, by Amount. (monthly) ...90

Table 18. Primery Source of Income of Chronically IIl Pation to Adnitted to Louisville General Hoepital February 5th Through Fobruary 14th, 1946, by Additional Source of Income.......................94

Tabl 19. Lest Known Ocoupation of Chronically 171 Patients Admitted to Loulsv ille General Hos $p 1$ tal Fobruary 5 th Thro ugh February 14th, 1946, by t1me of last employment. ...............................96

Table 20. Monthly Incom of Chronically Ill Patients Admitted to Louisville General Hospital February $5 \mathrm{th}$ Through February 14th, 1946, by Monthly Rent, Own Home, or Living in Instituti on................... 100

Table 2l. Treatment Recelved by Chronically III Patients Admitted to Louistille Ceneral Hospital February 5th through Pebruary 14th, 1846....................103

Table 22. Iouisville General Hospital Cin108 Attended, regularly or 0ccasionally, Chronically nil Patients Admit ted to Louisville General Fospital, February 5th 105 Through Pebruary 14th, 1946, (prior to Ho spitalization)

Tabise 23. Type of Care Rocommended for Chronically IIl Patients Admitted to Loulstille Ceneral Hoepltal Fobruery 5th Through February 14, 1946, by Thether Chronlc Fosp1tal is Indicated for the ir care....................109 
Table 24. Type of Care Rocommend ed for Patients on the Paychiatric Wards idmitted February 5 th Through Fobruary 14th, 1946, Iou1s rille General Howital, by Place where This Care Should be Secured.........110

Table 25. Probable Discharge Plans, desired Discharge Plans, Whe the $x$ Someone at Home to Help out, Chronically IIl Patients Admitted to Louisville General Hospital February 5th Through February 14th, 1946, on Hard at Time of study.......................11]

Table 26. Plans to continue Medical Care of Chronically III Patients damitted to Louisville General Hospital Fobruary 5th Through February 14th, 1946, Disoharged From Ho spital at Time of Study.................13

Table 27. Facllities for Medical Care Preferred to Present Arrangement (if arailable) by Chronically IIl Patients Admitted to Louistille General Hospital February 5th Through February 14th, 1946...........174

Table 28. Bxtent of Liedical Social Service to Chronically III Patients Admitted to Louisville General Hospital February 5th Tmough February 14th, 1946, as Indele ated by Form of Recording....................?

Table 29. Chronic Patients Cared for by V1siting Furse Assoc1ation, by Cases and Visits, Louisville, Kentucky,1943. 129

Table 30. Disabilities of Persons mployed at Goodwill Industries, February, $1946 \ldots \ldots \ldots \ldots \ldots \ldots \ldots \ldots \ldots \ldots \ldots . . \ldots 43$

Table 31. Work Glassifleation of Persons mployed at coodw111

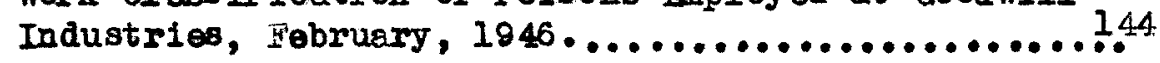

Table 32. Diagnosis of Population of Nursing Homes in Louis and Jeffers on County, June, 1945................254

Table 33. Duration of Stay of Population of Nursing Fomes in Loulsville and Jefferson County June, 1945...........

Table 34. Source of income, own or public assistance of Population of Nursing Homes in Louisville and Jefferson

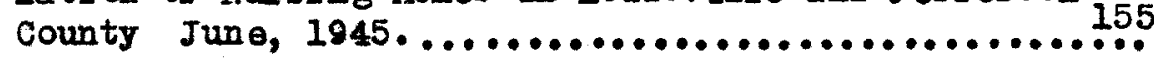

Table 35. Conditi on of Population of Nursing Homes in Louistille

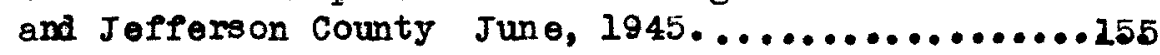

Pable 36. Type of care Received, Population of Nursing Homes in Loulsville and Jeffers on County November, 1945, by whether Temporary or Pemenent Resident.................256 
Table 37. Population of Public and Endowed Institutions in Louisville and Jofferson County hay-September, 1945,

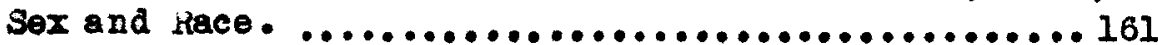

Table 38. Populati on of Public and dowed Institutions in Louisv ille and J efferson County liay-September,

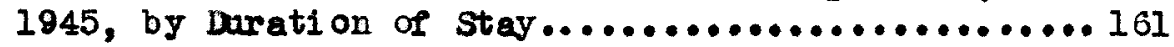

'Pable 39. Populati on of Public and fondowed Institutions in Louisville and Jeffers on County May-Beptember, 1945, by Diagnos is ............................

Table 40. Population of public and indowed Institutions in Louls ville and Jefferson County May- September,

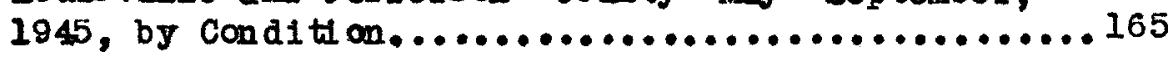

Table al. Populati on of Public and Fndowed Institutions in Louisville and Jefferson County November, 1945, by Type of Care Hếceired and Resident Status. ......166

Table 48. Population of Public and mdowd Institutions in Loulsville and Jefferson County November, 1945, by support...............................167

Table 43. Distribution of Cost of Institutional Care, Public Assistance, and Heal th and Felfare Services by Loeal, State, and Federal Governments.................

Table 44. Chronically Inl Patients in Endowod and Public Institutions, Private Nureing Homes, and In Own Homes, Louisville, Kentuc ky, Norember, 1945............. 1777

Total 45. Support of Chronically III Patients In Endowed and Public Institutions, Private Nursing Homes and In Own Homes, Louisvilie, Kentucky, November, 1945.....278

Total 46. Type of Care Required by Chronte elly IIl Patients in Fndored and Public Institutions, Pritrate Nursing Homes, and in Om Homes, Louis ville, Kentudky, Notem ber, $1945 \ldots \ldots \ldots \ldots \ldots \ldots \ldots \ldots \ldots \ldots \ldots \ldots \ldots \ldots \ldots \ldots . . \ldots 178$

Table 47. Hospitals in Loulsville, Kentucky, by Bed Capacity...2Re 
INTRODUCTIOS 
INTRODUCTICA

Although the problem and implications of chronic 11 lness will bo disoussed in thoir broader outlines, the purpose of this study 1s to seo more specifically how chronic illness affects a partieular group of patients. The questions, what are the probleme and the needs of the chronically 11l, what is the community doing to meot those neods, wat are the faclitiles and wat should they be, W11 be related to a representatire sample of Loalsville General Boap 1 tel patients.

Mang eirie groups in Iouistille have beon articulate in expressing the noed for planning for better convalescent and chron 10 eare, among them the Hospital Committee of the Loulstille Area Derelopment Association and the Health Councll of the Community Chest. Heelth and Felfare reports have stressed the need for improring and enlarging facilities. The latest contribution is contained in the report of Dr. A, C. Bacherer, who, by careful aneljais of the patients in Louis ille General Hoapital on June 5, 1945 found that 47 or $15 \%$ were in need of prolonged institutional care because of chronic disease. 1

Loulsville's first serious attenpt to learn the size of the problem was made in 1927 by a hospital advisory committee of aix members appointed by Mayor A. G. Will. The subjects to be studied

I Bachmejer, 4. C., Confidential Beport - preliminary draft, to Dr. Join Phair, Comissicoer of Bealth, January 5, 1946. 
by the abecomitteo rere divided into:

1. Chronically 111 in hospitals for acute eases.

8. Inctituticas for chron1es and so called inourables and homes for the eged.

5. Varlous homes for the aged under the auspices of churches, ote.

4. Care of ohronically 111 in the ir orn homes.

5. Ooevpational therapy end zchabilitation.

6. Lodical and nursing progrems for institutions caring for the chronieally 111 .

In onumaration of ehrcales in 1937 brought up-to-date the study of 1987, but did not Inelude patients of Ioulsoille Generel Hospital clinies, and the Publie Hoalth Marsing Asnoelation within its soope. In both studies ohronic disease pation to from 101 Income groups only ware enwmerated. The estimatod number needing emonic hospital care was detormined, but plans for auch a hospital were made in pretty general tarms and nothing came of it.

Dr. F. R. Bradey made a preliminary sarvey of hospital facilitios in Norember 1945 at the invitation of the Health Council and Louisville Area Development Association to determine the needfor expansion arter the war and consider the question of construeting a chronie hospital in the Louiarille area. 1

It 1s the plan of this study to determine from pationts

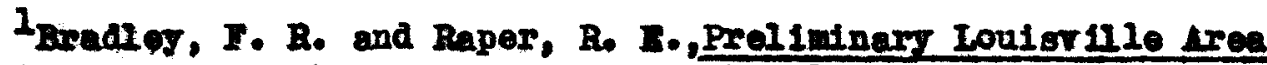
Hospital survor. St. Iouls, Mo., November 1845. 
adnitted to the wards of Loulsville General Hospital during the woak of Fobruary 5, 1946 through Fobruary 14, 1946, how many aro chronically inespacitated or prevented from leading produetire aelf-euffielent lives because of prolonged iliness or physical debility; wat proportion of totel edisisions they represent; what specific diseases and conditicns are responsible for their Ineapaolty; what type of care these patien to neod and what they recelve; whether these patiente desire a different type of oare from that which they receire; what pereentage are lnown to aocial agencies and tho hoapital social service department; what are tho acial and oconomie complications resulting from their illneas; That institutional and community rosourees are arailable to noet their noeds.

The tan-day persod Dobruary 5th through Fobruary 14th is chosen arbitrarily and beeause the brief intervening period separating the time of admisalon from the time that the investigation was conducted, when the chronic experience did not 110 domant but was uppermost in the life of exh patient studied makes it possible to secure a true pieture of the chronie situation.

This choice of tine was made with the knowledge that some of the patients rould still be in the hospital and rould be thinking of the adjustment they would have to make when they left, and that the remainder hering been discharged, would hare alre ady experienced sowe of the problems of adjustment and would hare delinite opinions on the plans they had had to make (how they fitted into tho exiating cosmunity framowork) and wat they really 
dea ired in the way of care.

To secure all the necessary information, it was declded to dirlde the patients into tro main groups; those in the hoapital at the time of the atudy, and those at home. 1 more desirable method of procedure would have been to follow the same group through the hoepital experience and after discharge to thelr homes but this was not possible due to linitations of t1mo. Instead, two groups were studied, and it is folt that a continuou pleture may be aeen by the Integration of these tro groups. Patien to Interrlered in the hospital were asked their plans upon diseharge; probable, what patient would desire, if to return home was there anjone to help out? Patients Interviewed at home were asked whether ther attended clinio, received nursing service, had a private physicion, took medicaments, whether they had ever applied for or considered Institutical care, and wat arrengements they would profer if $v$ arailable; Hone for the Aged and Infirm, private nursing home, old age benerol ent (ohurah) hones, better nursing at home, chronlo hoap 1tal, other.

For all patients studied the medical history was secured from the medical chart at the hospital. Nnother reason for seleoting recent admissions, many of whor were still in the wards, was because the modical recommendations could be diacussed directly with the doetors who were familiar with the cese, and wuch ralnable Interpretation which is lacking in the recoris, could be secured. Broad queations of polloy and generel medical interpretation ware scmet1mes referred to the staff mon and the residents, but in the 
main it was found that the most satisfactory opinions for Individual patients could be secured erom the doctor working airectly with the patient, usually on intern.

It is true that many patients adultted during a giren reak may reflect the Influence of the reather ar a disease or conditicn that may happen to be prevalent in the community at the timo, e.g., pneumonia. Fowrer, these would for the most part be acute Illnesses and would be discarded in the selection of cases for the purpose of this study, except where the patient is adnitted for on acute manifestation of a chronic illness or an intermittent acuto 111 eese and it can be derinitely dotormined from the modicel histary that the patient is a chronic.

lamissions were studied in preference to discharges for the reasons enumerated abore, but there is one major disadren tage to this mothod. Meny persons were admitted on observation or with provisical diagnoses, end a final diagnosis not reeceded unt1l the patient was discharged, therafore, in cases where the pationt was stll In the ward there mas hare been ho darinite diagnosis. Howerer, ehronicity as explained abore, is not defined entirely by diagnosis. In selecting the chron 10 ceses from among all admi asicns for the wook of February 5 through Fobruary 14 it was necessary to dofine ahrenic illneas in order that there be basie uniformity ond differentiati on from acute 1llness. Geses not conforming to the definition doaided upon were elininated as sabjects of the study. Dafinitions used in rartcous studies and 
artieles were considered, emong them:

Dr. F. R. Bradiey - der inition of ahronic beds;

"These given to the care of patients who are in either the residual or terminal stage of a disabling or incurable disease who do not require active modical eare and whose duration of atay ranges upward of six mon th $8^{\text {II }}$

Inis definition was discariod on sereral counts, primarily because of the philcsophy of defeatism and hopelessness (as oridenced by the use of the roris residual, terminal, incurable) which is entirely contrery to our thinking. Wo will show in the body of this paper, that most of these pati ents do require, and can benefit from modical care. Wo would agree only with the time faetor-of alx months.

Br. Innet P. Boas:

"IIness lasting a period of three manths a more which prevents the patient from following his accustomed dally routine end wich nocessitates modical or nums ing care In an institationn2

Mary C. Jarrett:

"Persons who have been or are likely to be incepacitated by d1sease for a peri od of at least three montha, that is, unable to follow the dally routine of the arerage normal person, whose incapacity will probably continue for an inderinite periodns

The definition of choice is that used in a study prepared for the

General issembly in Hartford, Connectiout in 1944 to determine

the need for a state Infirmary. This definition reads:

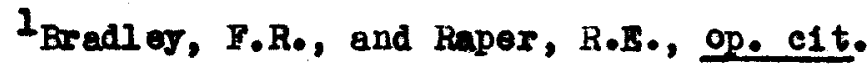

${ }^{2}$ Boes, Irnst P., "Chronic Di weses", Soclel Work Yoar Boak, ed. F.S. Hall, Russell Sage Foundation, NeT York, 1929. pp. 79-81.

Jarrett, Mary C., Chronie Illness in Nol York C1ty. 2 rols., (Columbia Univeraity Press, 1933) vol. 1., pp. v111-1x. 
- Alsese or condition of the body or personality whioh has been present at least six monthe or wich may be expected to continue at least six months, and wich interferes in th one's occupati on and normal physical and social liferl

It was Torbally approved by De. John Falker Moore, Chief of medical staf, Louisville General Hospital on Fobruary 7, 1946.

It is not the sole intention of this survey to discorer every chronioaly ill persco in Louistille General Hospital aring the per10d Fobruary 5 through Pebruary 14 in acder to def ine quant1tatively the extent of chronic illnoss. It is interesting to see what percentage of the population they form on a givenday or during a given week, but no permenent significance can be attachod to these figarea. The figures are purposerul however, in that they are indicative of the trende and serve to point up the necds in protiaion for the chronically 111 .

General Hospital patients are for the most part indigent pationts and can afford to pay little or nothing toward their medical care. They are, therefore, representative of the entire chronic group in the clty for whom planning must be done. Chron1e IIIness oceurs emong the higher income families as vell, but these peopbe are not directly the concern of society as they cen take care of themelves. One of the most striking fects revealed by the National Ebalth survey was that one in overy trenty femily heads in the reller population was unable to work because of chronle diaability, as contrated with only one in 250 heads of

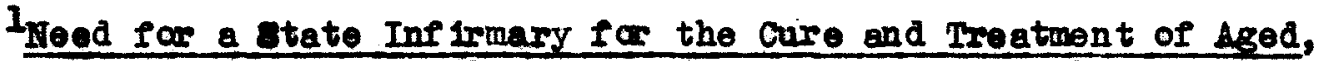
Infirm, and Chronlcally Ill Persons. 4 report to 1945 ceneral Assembly by the Pablic Felfare Council. Hartford, Conn., 144, p. 4. 
fanilles with incomes of $\$ 3,000$ and over, or phresing this anothar war, the frequency of chronic disabling disease is $87 \%$ higher among rellet el ients then amome fenilies of th enmual incomes orer $\$ 3,000$; in daya of chronic disability a ratio of $3: 1 .^{1}$

Prevalence of chronic disese may be studied in relation to the entire populati on by house to house canvess, but it is more common to study the chronically 111 whose ineapacity constituted a major problen for a velfare egency. For exemple, the census for Ner York city in the spring of 1988 incluied chronically ill perscns under the care of medical and social agenetes of the eity, Wi th the exelusion of tuberculosis and mental diseases.

ITe Hations Heel th. Interdepertmental Committeo to Coordinato Hoel th and Felfare Letivities. Washington, D. C., 1939. D. 43. 
CHAPIHAR I

CHRONIC ItUNESS: A COMONITY PROBLA 


\section{CHIPTAR I}

\section{CERCNIC IIINESS: 1 COMMONITY PROBLWA}

Aside from certain paychological atisfaction derived fran 11lness, in general 1 they be said that no one likes to be siok. Loute Iliness is an expensive comodity; the purchase of modical oare is high, end in terms or incapacity, dependency upon others, loss of earnings, disruption of family life, discomfort, pain, and the possibility of death, it 18 an unpleasant and undesirable experience. But when it is over, the patient, if he has survired, breathes a ighi of selief and after a period of convalescence resumes the normal pattern of living. Nther he gets well or he dic: it is as simple and final as that. This is not so with the chronically ill. The patient is uprooted for a longer period of time, perheps until the end of his life, which may be years after the onset of his 111ness.

Medical science has also made remarkable advances in the combetting of the acute, Infectious diseases. Infent mortality and death fran communicable diseases have been reduced, due to the organized efforts of public health of $101 \mathrm{lals}$, adding many years to the everage life expectancy. Soclety has opened 1 to purse wide for this work, remembering with terror the wholesale slaughter Inflicted by the plagues and scourges that have sometimes destroyed whole populations.

The chronic diseases have not been so drematic in their manifestations; the, chronically 111 individual has not had to wear a bell warning others of his approach, like the lepers of the 
midale ages. Ho aufers quietly, unobtrusirely in his home, in the so-ealled homes for the incurables, private nursing and convalescent homes, public almhouses, hoses for the aged, or in hoopitals intonded for the acutely 11l. Chronic diseases do not occur in cycles, or at any specific age. Its beginning may be insidicus, its crigin often unknown, its presence often unsuspected, its derelopment prolanged, its prognosis usually poor. Damege once done to body calls is never repaired, but the process may be arrested. It is the irrerocabllity of the damage inflicted that has given $r$ ise to the belier that the ohronic diseases are incurable. This is true in a limited senee, for the colls cannot be restored to normal, but the patient himself can always be benefited by medical relief, and can often be rehabllitated and retumed to some form of usenl activity. "The ahiof aim of treatment of the chronic disabilities in wich complete restitution to normal can no longer be expected, is to arrest the prom gress of the disesse end to enable the patient to maintain or rosume his accustomed place in society and in his family.wl The burden of chronie illnesa is not confined to the patient alone. It soon hes rerg serious repercussions within the family setting and spreads to include the entire community. It might almost be said that chronic illness is more of a social and economic problem then it is a pedical problen, for not only must the individual become edjusted to his illness, but so wust his family. Prolonged 1llness is apt to cause irritability, foelIngs of depression, sacrifice on the part of other family members,

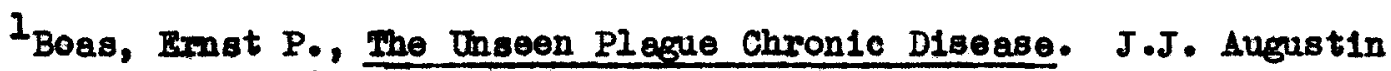
New York, 1940. pp. 22. 
Iriction and emotional strain. The meeting of cost for modical superviaion, medicaments, diets, and sick room supplies in case of unexpected acute 111 ness may call for a little 1ngenuity on the part of the homemaker in keeping the budget on an eren keel, but no homomaker, no matter hor akilled, can stretch I inf tod income or saringe for an indefinite period without serious deprivation and sufforing. Bren when the sick person is not the wage eamer, the never ending expenditures for doctors, medicine, etc., strains the femily purse. Ere is where the community takes over the role of prorider. Femily dependenoy and chronic alsease go hand in hand. It is also an unfortunate corollary that tho lowest Income families are the ones ouffering from the most chronis disease. The National Baalth Surrey fornd that two persons on rel lef wore disabled for co week or longer by chronie disesse for erery person in the middle and highest income groups.l The chronically 111 come to the attention of the community too often not as medieal but rather as welfare problems. They have been provided with whaterer eare tho coummity happens to have arallable; have been fitted into the exiating Iramework of outdoor relief end rarious assortments of institutionel care. The almahouse opene 1 ts arms wde to receire this dependent group in to Ita fanily of unfortunates.

Chronic Invalidity is increasing. Between 1820-1930 in Nor York City the death rate from chronic diseases incressed $32.5 \%$ while the population increased $23 \%$. There are several thinge accounting for this; the larger population of older people, improvewent in 
recording diegoses on death certificates, and some actuel increase of these diseases.

There is considerable rariation in the definition of a chronie disese. What differentiates chronic from acute? Can wo sey that all heart diseese is chronic, every illnoss of three or six months curation is ohronte, every diseses whose outlook is bleak is chronier BON Bimple if chrenielty could be absolutely el assified by diagnosis, duration, prognosis; but chronicity is a relativo concept. sone acute infectious disesses give rise to chronie disabllity (e.g. taberculosis, eyphilis) or they nay occur Intermittently with chronic illnesses, or there war be acute manifestatices of a latent chronie condition. Oae cannot judge by diagnosia alone whether a diseose is chronle or not.

Duration depende upon the nature of the disease, how early the di agnosis is made and treatment begun, and the acouracy of the dagmosis. Brights disease, for example, may $k 111$ in a for days or mes cause invaliaiam for yeara.

It has been brought out that chronic patients are commonly regarded as incurable patients but this is not al waps true because modicine often has a great deal to offor the chronicelly 111.

In the face of all this rariation it would be untise to venture on absolute definition, yet it seems to be generally agreed that co of the main differences betreen acute and chronic 11Iness 1s the self-linited course of the former, the alowly progressive morbid process of the latter. Mary C. Jarret feels that there is IIttie homogenelty among the chronically 11l, exept for the fairly 
uniform neglect of society to study their problems and proride for their care. 1

socording to the findings of the Naticnel Foalth Surrey. a giten chronic disease mar hare Tarying signifleance in terms of provalence, disability, and mortality. No one disease ranks first when considered Irom these ori toria. Eourt disease ranks first as a cause of death but sheumatism is wost provalent and the nerrous and mental disesses cause the greatcet disability.2 Mortallty If gares, while 1lluminating, do not tell the wole stcry for they show nothing of the years of sufrering the patient may hare undorgone. In this reapeet chronle diseases listed as cause of disability are more retealing. Rhermatism, second in disability, exipples and causes far mare invalidity then cancer which renks seecnd as a canse of death. Pheunatiom is also the most prevalent chronic disegse but fourteenth as a cause of death. 3

Chronic disease is all about us. There are for families in the entire nation that are not affected by chronic disease at one tiwe or another.

The first ser lous attempt to eatimate the prevalence of chronic diseese was made by the Nelfare ccunoil of Ner Tork city in 1988. 4 consus wea made for co woek in 1988 of all the chronically 111 under the care of $218 \mathrm{mdical}$ and soolal agonc108. Twenty-thousend and seren-hundred eases wero recorded, represent ing a ratio to the population of 00 in 310. It was estimated that

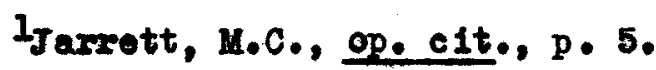

${ }^{8}$ Boas, ..P., op. elt., p. 11 .

3Ib1e., g. 11 .
} 
thie figure representod only the dependent chronically 111 or one-third of the chronically 111 in the entire city. Therefore, one percent of the population was disabled by chronic disease. Tubereulosis and montal diseases are exeluded.1

The state of Massachusetts made chronic disease surveys in 1989, 1930, and 1931. By actual house to house canvass of large population groups it ras found that ten to twelve percent of the popolation wore sufforing from some form of chronic disease, includIng tubereulosis and mental disese. 2

The Net1onel Ealth Survey undertaken by the United States Public Balth Service in 1935 gare more complete informaticn about the prevalence of chronic 1 llness than was ever done before. Three-quarters of a million femilies comprising almost three million Individuals were studied by careful sampling methods.3 Nlmost $10 \%$ of persons with chrcule lliness were ohildren wdar the age of fifteen, 35.18 were goung adults from twenty-five to forty-four years of age, 33\% were between forty-fire and sixty-f aur years of age, and $15.6 \%$ wore sixty-f ive years of age and oldor. With $70 \%$ of cases occurring in persons under fifty-five years of life, it can be seen that the problem is one of the produetite years of 1118.

It was found that 177 persos per thousand wore auffering Irom a chronic disease or impeirnent, or almost cae in overy fite persons.

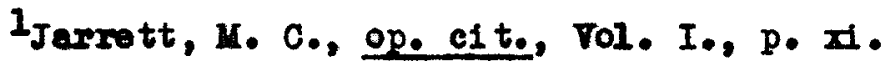

2Bos, B. P., The Inseen Pleque Chronic Diseses

Ferrott, Goorge St. J. and others, The Hational Foalth surrey. Poprint No. 2098 from the Public Helth Report, pp. I-3. 
Disesses, the suptoms of which vere stated to have been present for three wonths or longer, whether or not disabling, were classified as chronic. It was found that anong the diseases of childhood, the ratio of acuto to chronic was twelve to one, but among persons aged sixty-fire and orer, the majority of tho serious 1llnesses were chronic, the ratio of acute to chronic IIIneas being 0.6 to cne.

Among pereons aged aixty-five and over who wore chrcaleally 111, about one-third were alasifled as inval 1ds, but there were also many chronic invalids in the jounger age groups. Falf of the intal ids in the tudy were below the age of fifty-five.l Sbout two percent of the population enumerated rere reported to have a permanent orthopedic impalrment or such a serious nature that the were considered to be partially or completely crippled, deformed or paraljzed. About twenty percent of thls group were Incapacitated throughout practically the whole year.2

Two of the most significant facts that stand out among the Iindings of the survey are first, that 17.7 pereent of persons were reported to hate a chronic disease or impairment, and second, that 11.7 parcent were chronic intalids.

Hore recent studies have been done in various communities, among them a survey of whit fenilies in the Bastern Hoalth District of Baltimore in 1940.

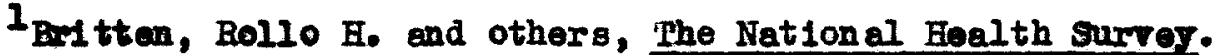
Reprint Ho. 2143 from The Public Fell Reports, p. 8-16. 2. Ibld., p. 17 . 
In 1943 the Connect1eut cener al Assembly directed the state Public Welfare Cancil to make an investigation to study the need for infirmary care for dependent persons with chronic and incurable disease for whom no proper proviation was arailable in the almahouses or general hospitals.

The surreys conducted in Iouisvilie to determine how many chronically 111 there are, and wat the facilities are for their eare, will be disersaed at a later point.l

The Haticnal Bealth survey and other studiea done locally have show the magnitude of the problem, and yet is is entirely taken for grented end aceepted as is spring following the winter. Unfortunately, this complaceney does not seen to be conIned to the lay public alone, but is connonplace emong the medical profession, whose task it should be to combat the monseen plagne"-chronle disease..$^{2}$ In the hospitals, and in private practice alike, many of the 1llnesses with which the phroiclans come in contact, are the chronic IIInesses.

There are sereal courves open for the patient with a chronle disease. He may tro at himbelf, he my aroid seeking modieal treatment belleving that it will not help him, he may not think his condition serious enough to require modical care, he may not have the mo ans to pay for the care and, therefore, not parme 1t, ho may not have faith in doctors and neglect his condition

\footnotetext{
1 chapter II.

Zoss, B.P., The Unseen Plegue Chronic Disesse
} 
for that reason, or convinced that somone w11l be able to help him, mog go froctor to doctor in search of health. The indifference of the medical profession may be explained by several factors. Che of the most Impartant of those is the bellef in the incurability of chronle disease, and the idea that chronic disease is peculier to the aged and, therefore, beyond the acope of medical acience. In answer to the former, it need only be pointed out that meny diseases wich only a fow hort yeers ago were looked upon with dread, and ich meant almost certain death, now have treatments adequately described in the modical texts and routinely carried out with high percentage of success. Tuberouloais, cancer, heart disease, if diagnosed and carod for early are highly amonable to avcesaful treatment. Whe lack of a speoific remedy has been to o much lamented while there has been all too little utilization of the effective measures we possess. dotually there are but fow specisic remedies within the ontire realn of therapeuticsn. 1 Many diseases, although not lending themselves to precise logical theraf, such as insulin for diabotes, I1ver extract for pernicias anemia, pentelli in for pneumonia, can nevertheleas be treated. The cause of a disease may be known, but not the means to treat it, or ve may successfully treat a disease without knowing its etiology. Boes points out that in the great majority of 11 nesses treatment is not strietly ouratire, but is directed along three main lines: semoral of the causetire

Hargolis, H. M., Diagnosis and Treatment of Arthritis and ulled Dieorders. Paul B. Eoober, Inc. Now YoIk, 1941. p. V11. 
agent, restoration of functional capacity, and dealing with the otructural abnormalities resulting from disesse.2 We know that patients with cancer of the stomach can often be helped tremendoualy through proper dietary regimen; that various forms of physiotherapy rellere the arthritie's pains and help to restore function; that. diuretic therapy is often of aid in cardiac fallure. The very minimam of acoomplishment is relief of pain through medicaments ar surgical meacures, and often a great deal more can be done in the treatment of the rafious chronic diseases. "Treatment can be auccesaful even when it is not strietly etiological, by attempting to reatore normal paychosomatic functioning". 2

Age is another reason offered $f$ or condoning the defeatist attitude. Disabilities cased by chronic disease are ascribed to old ago when in fact the two are not synonymous. True aging is a phenomenon occurring after the age of serenty and most of the disabilities occurring at an earlier age are due to chronic disease and not to old age. "Age is a matter of adjustment, not years". 3 Dr. Lewellym Berker speaks of two kinds of old age; physiologieal, which is a vory gradual process of atrophy or decline in functicnal capacity; and pathological, which is a condition caused by isese.4 Too often pathological old age is confused for physiological, and the rubber stamp diagnosis naenile"

1 Boas, F.P., The Unseen Plague Chronic Disease. p. 20.

2m1d., p. 21

3 Statement by Dr. John D. Trawlek, Assistant Director of Health, Loulsville and Jefferson County; personal intervier February 12, 1946

4axirer, Iowellyn F. "On the Care of the Aged". The Canadian Hos pital. Hay 1941. pp. 31-38. 
attached to the allment. A clear distinotion shaid be mado between senescence, which refere to normel old age, end senillty, the aynonym for abnormal old age. Ceriatries is that depart ment of molcine which treats of the elinical problems of senescence and senility. 1

It is pretty generally agreed that if the diagnosis of aenility was broken dom into its more specifie components, better medicel study and treatment would result. The misconception that nothing can be done increases with patients wo are lobellod Incurable or sentle.

nother reason for the indifference of the medical profession Is the fact that the chron 1c disesses lack the gl amor and exc1tement of the acute. The chronic services attract fower physiclans to their celling than do the eoute. This is a serious problen in rearuiting the staff for a chronic diseage hospltal. Young doctors in selecting internships are not willing to derote their entire course of study to the chronic disesses. Chronic patients on the wards of an acute disease hospital are likely to be the most neglected. As their condition may show little change from day to dey, the doctors give then less and less attention, while answering the challenge of the acute diseses. Orten foel ing helpl eas before the aufferings of those they cannot help, they trum eagerlJ to those for whon there ts specific therapj.

A third fector aceounting for the indifference of the medieal profossion is their leeling that they are working piece-mel with

$I_{\text {Dorland, M.A. Newen. The American Hlustrated Yodical }}$ Dieticnary. W. B. Saunders Co., Philadelphia, 1944. 
the chronic patient; that his modical treatment is coly part of 1t, but that somothing alse is lacking wht ah prevente then fron getting the patient wall. Ulthough this thinking 1s apparently not entirely cryatallized in the minds of many physiclans, they do experience some misgiving in plenning treatment for this pationt beceuse they know that the kind of life he lives will hare es much effect upon his physical condition as will specific modicel therapy. Chronic disease creates more social and econcmic problens than acute 1liness does. The social factors In treatment mat be given greater consideration than is boing done. The patient must be seen as a hole person, not as an ache or pain in a locallasd area. Somotimes this integration of medical and sociel treatwont is done with the assistance of a modical social worker, but again there is danger of the doctor pertitioning off the wedical erca the social, and with a great sigh of relief, assigning the latter to the social worker. A medical-gocial plan cannot begin to operate effectively unless there is perfeot coordination between physician and social worker Wh the patient and his problems as the focus, not as an object to be divided up as so much modical and so much social material.

Fealth and illness are relative terms. While it is acoepted w theut questica that an individual who experlences certain somatic or peychle disorders is ill, the prefix "chronte" is usvalif not attached to his malady unless it is of long duration (in the Messachusetts surreys the median period of disabilits was found to be and one-half years but twenty-two percent of the 
8roup were di sebled over a fire-year period; ${ }^{1}$ in the Ner York aty stady the period of disability wes 5.8 yeara $^{2}$ ), bows an insidious onset, is progressive in its course, is destructive of the body cells, and will leare treces of perwenent infury. Some diseses almost always follow this pattern and are, therefore, clasiIled se chronic without regari to indivimal deviations (0.g. heart disesse, cencer, tuberoulosis), but other disesses may be conaidered acute in co case, chronte in enother, depending upon the duration, the progxeas of the disease, and other developmental faotors (0.8. Intestinal disoriers, diseases of the skin, gsnecological disorders). morontc Invalidism is of ten the result of discontinuance of modical care when the acute symptoms have bean rel leved". 3

Eren after the petient's condition has been described as chronic, there is considerable rarlation in the enount or incapacity that is involved to the indiridual patient. cone way to measure incapacity is by the objective standard, days 10st from rork. The Naticnal Health survey shored that 6.3 deys per person were lost anmally from wonk or other usual pursuit by reson of chronle disease wich disabled for one week or more.4 Two patients IJing side by side on the ward, both having diabetes,

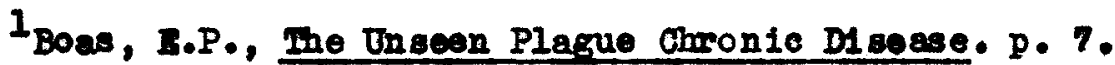

Jarrett, M.C., Op. C1t,, rol. 1, p. 117

Ibla., rol. 1, pp. 2-3.

${ }^{4}$ mertten, R. H., op. cit., p. 15 . 
mey be experiencing difforent levels of incapacity; the one having frequent admissions for disbetic cone beeave he negloets to take his insul in, the other getting along suffloiently well on a dietary regiwen and not neoding insulin. A thind person an the rard, also a diabotic, may have had a too amputated as a result of gangrene following infeotion.

II chronics are not invalids. "There are many degrees of chronic Iliness lying between a disease so well controlled that 1t causes no practical ineonven lence and one that results in complete hel ples aness". I

To ochform to the vary ing degress of chronic illness are varf ous levels of treatmont renging from simple custcilal care to medical services of a skilled speciellst. Dr. Irnst Boas has conventently classified the different types of care accarding to their medical needs.2

$$
\begin{aligned}
& \text { Mlass } \triangle \text { - Patients requiring modical care for diagnosis } \\
& \text { and treatmont } \\
& \text { Alass B - Patients requiring chierly skilled nursing care } \\
& \text { class C - Patients requiring only custodial care }
\end{aligned}
$$

Qlass 1 wa be lllustrated by a patient with a heart disease who has had an attack of hoart failure and noeds constant medical survelllence with a trained nurse to look after him and carefulls follow the physicion's orders. Another patient in this class is one suffering from hemiplegia (paral yais of one stde of the boly) as a result of a stroke. If neglected he may never regain the

\footnotetext{
IJarrett, M.C., op. elt., rol. 1, p. 2

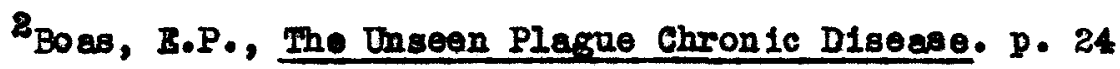


use of the side of his body but with good care and some physiatherapeut1c neasures properly epplied, may be teught to walk whin sereral mon ths.

A class $B$ patient is one tho has passed the active stage of therapy but the disesse is still progressing or is stationary Wth little chance for recorery, or the patient is on the way to recorery end still needs active nursing care. 1s examples of this alass there is inoperable carcinoma, ostecnyelitis, neuro logieal conditions. The encephalits victim, for example, mas be completely halpless. His mind may be alert, but ho is unable to turn in his bed and needs expert care to rellere his ouffering, to provent bed sores, and to help him to carry on necessary bodily functions. These patients maj noed bakinge, massage, sodative baths, enemes, and Irrigations, at various Himes. There may be need for a special diet whose contents need to be changed as tho patient's condition changes. This group is usually the smallest of the three.

Class ocotains that group of patients who have passed beyond the B stage. The ir disease is no longer ative. The aisease procesa has been arrested but it has left the patient with permenent aisability which makes it necessary for him to have some attendent care. patient on on 15 require aseistance in bathing, iressing, end eating. El may need an occastonal aspirin or APC tablet, but no other medication.

- It should be emphasized that these alassifications are not 
Intended as guides to indicate vhere types A, B, and neede may best be net. It flrat glance 1t might seem that hospital care is Inparative for croups $A$ and $B$, and a custodial institution for group 6 , but such is not the case. Care for all three types may be given in a hospital, other institution, clinic, ar at home. A clasa A pationt may be, and usually is, eared for in a hospital but he may receive intengive care in a clinic or by a private physicien as wall. Glas B care may be given in a hospital and also by a trained nurse under a doctor's supervision, at houie. Class c caro is usually given in an institution for econculc mose than for modical reapons, but when the hone is suitable, cus tolial care may be provided there, by a canpetent member of the fanily. In the How Tork city study It was found that three-fifths needed medical care, but of these only comthind required hospital care. For the rast, clinic service was sufficient. Tworfiths of all these pecple needed custodial or attendant care. I

These classifications, while not stating where each type of patient should be cared for, are helpful in that they show the various categories of modical need. In plenning for the chronically 111 patient, there should be flexibllity in considering the noeds of the patient at any particular point in his illness. There is nothing stationary about 1llness. Erenwhon it is said that the disesse process has stopped in class C patients, woh a statoment 18 relative and is not cognizant of the fact that nothing in Iife ever comes to a standstill while there is life. A patient mas require

IJarratt, M.C., op. c1t., p. 117. 
olass 1 care for everal deys, and having had active modical treatment, gone on to alass B under the care of a skilled competent nurse. He then reaches the point where the disesse is arrested but the disability has become permanent and he will require assistanco in performing necessary physical duties. On the other hand, a class C patient may suddenly have an acute exacerbation of his illness or an acute intermediary alsease which may bring him back to the 1 stage, and the process is repeated. In plenning for the chronic patient these things mat be kept in mind, lest tho patient find himself pidgeonholed in are group and not recelving the care he needs at a partioular point in his illness.

There is also the danger that raluable facilities may be wasted when a patient is receiring a more complex type of care then his condition requires. It is an eccomic loss to the communit when a custodial patient is occupying valuable space in a general hospital. He is depriving other patients of the class A care that they noed, as well as depriving himself of the recreatical and occupational facilities good custodial institution should offer. Some of the chronically 111 receive unnecessarily expensive care, and others do not receive adequate care suited to their conditions. In the New Tork city study of 20,700 pecple one-fifth were found to be receiving Inadoquate care, and one-tenth more arilled form of care than they requised.1

Than wo spoak of a chronic hospital we maan a modern hospital which posaesses all the facilitios used in earing for the acutely

IIb1d., p. xi11. 
111, if not more, but has the additional adrantage of of fering care for long periods of time. A chronlc hospital offers a broad plan of treatment that considers all the aspects of the Illness and can be carried on for as long a period as is necessary. In some cases, early hospitalization for a fer months may lint the further progress of the disease. On the admission alips in hospitals for the acutely 111 wo 11 nd notations reading Whom diabetio for many years", "Old arthritic case-several previous adissions", These patients should proper iy be adnitted to a chronic hospital. Other logical candidates for the chronic hoppitel are the people whose poor home conditions prohibit eny measure of recovery, and those who are seemingly not benefited by elinie visits for one reason or another.

There can be little continuity in clinic troatuent when the patient is soen by a different physician each time, and wen treatment is directed without consideration for the home to in ioh the petient will be returning. The patient mar spend nearly 168 hours in his home, and only a few minutes each weok in the clinic. The dootor in heart olinic is sincere in his efforts to help the man with early hypertensive eardio rascular disease, but there is littlo he can do about the throe flights of stalms leading up to a dingy, windorless room on the top floor of a rocming house to wich the man must retarn after gotting a refill of digitalis and leaving the elinic. sdded to that, the man may be holding dom a job as a labocer. Ho soon becomes a fit candidate far a chronic hospital. 
There are fer institutions in the United states deroted aolely to the care of the clronically 11l. One of the moat outstanding of these is the Monteflore Hospital, a roluntary hosp Itel in New York C1ty with bod sapacity of about 714. New York City is also fortunate in having the firwt municipally owned and operated institution for chronic patients in merica, the Hospital for Ohronic D1seases on Falfare Island. Appendix II contalns a deseription of Monterfore Hospital and the Hospital for Chronic Diseses on Welfare Island.

sone adinistrators are of the opinion, howerer, that there should not be separate accomodations for chronic patienta, and that they should cotinue to be cared for in hospitals for the acutely 111, with the concession that there be separate wards for chronie patients. Whe best way to plan for the chronic disease patient is to Integrate his care with the care of the acutely sick patient in the general hospital schemen.1 several arguments are adrenced in favor of rotaining the chronically ill in the general hospital:

1 - A chronic diseses section is less expensive to maintain than an Independent chronic disease hospital.

2 - Chronic patients require the came diagnostic and therapoutic racilitios as do acutely 111 patients.

3 - A disese process consists of sereral phases, acute, chronic, and incurable, and, therefore a single phase cennot be 1801 ated for study.

4- Although it is true that chronic patients in a general hoapital are noglected by the ataf, "independence, is,

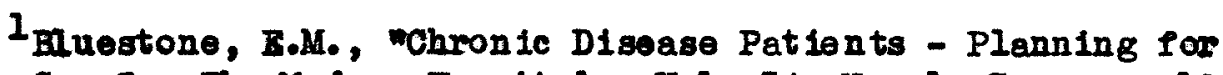
Their Caren. The Moderm Hospital. Vol. 54. No. 1. J muary, 1940, p. 66. 
howerer, an expensive and unecessary lurury", I

5 - In the general hospital facllities are arailable for prompt treatment of emergencies.

6 - Doctors ar more likaly to be elert to acute symptome then is the case in on institution solely for chronic diseases.

7 - Fom doetar and nurses like to wark in a hospital deroted salely to the care of the chronically 111.

In the Springfield General Hospital, Springfi el d, Massachasetts, a wand in the hospital is reserved for chronic diseane patienta ware they are given the same examinations, modicel work up, and treatment as acute pat1ents. It wes found that the mean arerage stay per patient was 243 days. The medien per admission was 65 days.2

In a city the size of Loufsville, coe chronic disease ward could hardy begin to meet the existing need. About twice the alze of Springfield, Massachusetts, Iouisville could fill a thousend bed hospital two weeks after completicn. 3

Hospitel care is not the only answer to the problen of the chronically 111. In the Now York ofty survey three-tif the of all the chronically 111 needed medic al care, but of these only one-third required hospital care; for the romainder elinic service was sufflclent. Tromifths of the entire group needed custodial or attendant care.4 Hot all of the ehronically ill need institutical

I IbIt.: P. 66.

BWalker, Bugene and Dixcm, Jennie, "Chronie Diaease Ward Ten Years ifter". The Modern Fospitel. vol. 64. No. 6. June, 1945, p. 55.

3gtatement by Dr. John D. Trawick, Lsst. Director of Health, Iouisville Jefferson County, Personal Intertiew, Feb., 12, 1946.

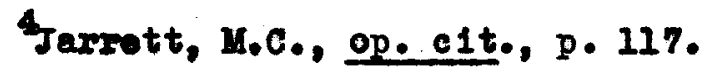


care, medicel or eustodiel, and a relatively mall percentage need to be hospital 1zed. Wconomic and social expediency, not modical need is by far the major reason for institutional care of the chrontcelly 111, particularly emong the aged". I "It wald be posalble for atate insti tations to be ballt to house and care for all dependent chronically ill, but a more acceptable social philosophy would hold that such institutions are really signs of fallure to prevent the disorders that necessitated inetitutionalization. Tharefore, consideration should be given to the questions of proriding adequate modical care in the home or home commanity. with the institution es the lest resort or facility for ach care as cannot be provided otharwisen, 2

same pationts can be treated at home after a relatively short atay at a chronle hosp1tal, some do not noed hospitalization at all, others could continue eaming a living while having private physiclan care or attending clinic, and others can be in foster homes or nuraing homes or benerolent institutions. All of these are deatrablo "as long as they are not intended as means of circumrenting necessary hospltalizati an, 3

The danger $11 e$ in the failure to proride chronic hospital care when it is needed, and in not oraluating the needs of each

Iuason, Clifford V., "Lots Keep the Old Cray Kare in Harnees". The Modem Hospitel. Vol. 62. No. 2. February, 1944, p. 82

Geed Ior a state Ine irmary, p. 36.

Bosenfield, Isadore, "Care of the Chronic Sick". Hogpitals, November, 1944, p. 50 . 
Individual in the light of that his illness means to him and how ho can best be helped. Facilities ahould be chosen with consideration for the age of the patient, the degree and nature of the disability, his mental capacity and temperament. It is obvious that children should never be housed with senile patients, that adolescents and young adul ta row easily reatless and must be kopt occupied, that elderly but montally alert adults are unhappy whon kept with montally deteriorated, senile, noiby, or offensive patients their om age. Pationts on their wey to recorery do not like to share cre ward wi th terminal cases as such a situation 1a extremely depressing; ambulent cases and bedridden patient do not make good company as the former is active and mas spend time outdoors if the hospital has well kept Erounds with adequate aupervisian for this purpose, and the other grows tired and complatning of having to spend long boresome hours in one place. Moat patients who have had active IIves and many Interests, and if they are not too sick, want to be in compang that is stimulating to them, in an environment which offers oppar tunity to continue with their old intereste or develop new ones. They object to radical changes in their living pattern, to being in the company of other patiente who are quarrelsome, noloy, demending. Obriously, the best place to satisfy the temperaments of the different patients $18 \mathrm{Fight}$ in their ove homes. And unless these homes have never been a sow ce or satisfaction or cannot now rulI11l the minimal qualifications as a place for medical troatment, It should be the aim of every one who plans the facilitiea for the chronically 111 to list the patients on home as the number one 
resource. In the home, dicel treatment is either brought to the patient in the form of a private physician or city physicien, or he goes outside to the appropriate al in 1c to receive his treatment there. A nursing gexvice is considered an ather means for securing care in the home. Another important resource, and often orerlooked, is the houselreep ing alie. These will be discussed more fully at a rur ther point.

The obstacles to hone care are the physical make-up of the home, uncooperative family (whether intentionally or not), poor nursing, and insufficlent public ass 1stance. The New York City surrey revealed that probably one-fourthof those living at home should have bee $n$ in ingtitutions, and that the mejorty or persons not properly cared $f$ or at home would not need institutional care if their home condition could be adjusted, but about one-third could recelre suitable care only in an institution.l Three sets of factors were considered in judging wother the home was suitable for the patients care: the physieal condition of the home, family attitudes (towards the patient, and the patient's attitude towards the family), the make-up of the femily (ability of the members of the femily to attend to the needs of the sick person).

Poster homes, nursing or boarding homes, benevolent ins ti tutions, are also parts of a program for the care of the chronically 111; the nuesing or boarding howe being of a sem-institutional nature. They are a desirable substitute for the patient's orn hame in that ther offer the foeilities which the patient's hame has failed to proride.

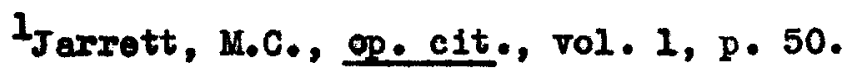


4 well regulated aystem of foster home and nursing and boarding home care is lass expensive than institutional care. The tendeney has been to think in terms of foster homes for children, wall or otherwse, but such a plan has often times proved successful when atterpted with aged people who are not peychotic or mentally defectire or senile. The Monteflore Home in Glereland, Ohio, which is devoted to the care of Jewish aged and infirm, has as a regular part of its progrem the placing of well aged in $f$ oster homes.l Wth facilities for chronie earo so limited, it has been quito conmon prectice to ut1lizo for the chronically 111 patient, those facilities reserved for the caralescent recovering frem acute 11lness. Conval eseent care 1s, as a rule, in greater denend for patients from the surgical wards than from the wodical wards and we find that a moch larger proportion of chronic patiente como from the medicel wards. It would seem, therefore, that the use of faclities intended for the convalescent patient, usuelly surgicel, by the chronic patient, is not a very wise plen while corralescent resources are also quite limited. The New York C1ty survey found that one-fourth of the people in convalescent homes were chronically 111.2 In the Louisville Home for the sged and Infirw twenty beds are reserved for convalescent eare, but with the steady increase through the jears in the number of chronically ill admitted to the home, there hes been no strict distinction bade between the chronic and the convalescent patient, and chronic patients are occupying

1 Weil, Julius, "The Aged Ill Need a special ized Stafe. Eospitals, March, 1945.

ZJarrett, M.C., op. c1t., vol. 1, p. 53. 
some of these beds intended for another parpose. Soctal workers are guilty of promoting this practice and ahall in all liklihood continue to make such referrals until the tiwe when there shall be separate and adequate resources for caring for the chronically 111.

whus we find a rery confused picture; patients at home tho should be in hospitals, phitients in hospitals who should be in less complex Institutions, patients in homes for the aged that are not prepared to minister to their noeds, patients in conralescent homes oceupying beds needed for another purpose. A mad confusion of patients and institutions-the patients scrambling to find refuge wherever thes may, the institutions adnitting them gradgingly, and haring admitted then not giving then the eare best adapted to their needs". 1 
CHLPTER II

THE STUDY OF LOUISVIIIE GRNERAL HOSPITAL PATIENTS 


\section{CHAPTER II}

THE STUDY OF LOUISVIILE GENERAL HOSPITAL PATIENTS

The problem of chronic 1llness is widespread but makes no lasting 1mpression when described from the viewpoint of the nation as a whole. The tuberculosis rate is high for the entire nation, but Kentucky residents were much more impressed by the Incidence of the disease when they nere informed by the committee for Kentuaky that their state had the third highest incident rate in the nation. It 18, therefore, the purpose of this peper to bring the problem of chronic disease down to the locel level by surreying a representative group of patients in Louisvillo Coneral Hosp1tal, the city's only general tax-supported hospital.

The problem of chronic illness has long been of ecocern to the people of Louisville but as yet no formal progrem of planning for the chronically 111 has been inltiated. Planning must, of course, be preceded by careful study, and such atuig has been attempted at various times by hoalth and social groups. This study attempts to Integrate some of their findings and to relate them to a group representing the larger communt for whom chronic facilities must be planned; the chronically ill patients of Louisville General Eo spital. By means of case study on an illustrative basis it is Intended to point up the needs in this area. Sone masure of the prevalence of chronic 1liness is obtained in the present study, but more revealing for this purpose are the 1927 and 1937 studiea sponsored by the Health Council of the Community Chest. 
The 1927 stady was done in answer to requesta fran tro different groups of the Communlty Chest; the Advisory Coumoil and the Budget Cocmitteo. The Advisory Covncil was interested in seeing the whole question of inadequate chronic facilities taisen up by a joint Cheat committee; the Budeet Committee on the ot her hand asked that the Health council study the provision for chronic and incurable patients, since an expansicn of the Kings Daughters Homs for the Incurables hed been contemplated. A Hoapital Advisory Comittee of six members was appointed by Mayor 1. 1. Will, composed of the following subcomittees: on chronic lliness in hsopitals for acute oases; on Institutions for chronically 111 and somcalled Incurables and homes for the aged; on rarious hones for the aged und or the augp iees of churches and other groups; on care of the chronically 111 in their orn homes; on occupational therapy and rebabilitation; and one on the medieal and nursing program for institutions caring for the chronieally ill.

By definition a chrcaically ill person was accepted as being disabled and requiring three months or more of institutional care, elther at a hospital or special institution, in which case one mas hope for funeticnal restoration and physical abilit on the part of the patient to take hy place in the comminity, as distinguishod Iran the incurable patient wo will not be improred by institutional or modical care.

The study was done in two parts, the firat part consisting of the atudy of chronic patients knom to social agencies, free ingtitutions, and in the modical and surgieal wards and clinics of the Louisrille 
hospitals for a three week period, February 7 through February 28, 1927; the second part of the atudy conducted by Dx. Joln Walker Yoore being a ono-iay survey of chronic and incurable pationts at Iouisville Ceneral Hospital Mey 2, 1927. No distinction was made between chronic and incurable patients in the three weoks study. while in the one-day surrey particular attention was paid to Incurables as distinguishod from chronic patients, and to the num ber of both types of patients haring no homes.

Nuch wore complete information was gathered from Louisville General Hospital where the study was done by the social service department in conjunction with the medical staf, than from the other participating haspitals. The total number of adult patients In the modicel and surgical wards and clinics of Loulsville General Hospital was 1980. Of these 323 or $17 \%$ were chronically 111. or the 323,140 or $45 \%$ were not in need of the type of oare which a hoopital equipped to eare for the acutely 111 is in a position to Give, including both the ward and the clinic patients. The clinic pat lents were in need of moxe care then the clinic could provide but not the type of care which required adnission to the hospital proper. Tiventy-ifie of the 140 patients could have been cared for in a wall-construeted home for the aged, bat the remainder needed the special care which a chronic inatitution could of fer. Twenty of the 25 patients needing home for the care care occupying beds in the rards, 17 in the modical and three in the surgical. The remaining five patienta wore attending the medical clinic. It was found that the modical wards were getting the largest percentage of the chronic patients. 
Inalys is of the 115 patients requiring chronic hospital care showed that 26 were twenty-five years of age and under, 23 were twentysix and under forty years of age, and 25 wore sixty years of ago and orer. Therefore, less than $25 \%$ of these patients were s1xty Jears of age and under while almost $50 \%$ vere under $f$ orty years of ege. Orer $75 \%$ were men, $25 \%$ w cmen.

The other hospital repcrted only 27 chronic cases who should be proplded for in a special chronic hospital or institution. Other reporting agencles were Faverly Hills Sanitorium, Olght par sons; KIngs Daughters Bome for Incurable, 17 persons; Home for the Aged and Infirm, 41 peraons; Jeffers on Cotnty Home for the 4 ged, two persons; and Public Health Nursing Association, Fently Service Orgenization, Jewish Welfare Foderation, combined, 41 persons. The total number of chronieally ill in Louisville as reported by social agencies, Iree instituticns, Louisville General and other hospitels dur ing the three weeks survey in 1927 was 276.

In the one-day survey of Louistille Coneral Hoapital patients, 102 patients or $26.2 \%$ of the totel populati on of 388 were found to be chronic ar incurable. The proportion of chronically 111 in the one-das survey was, therefore, higher than in the throo wooks atudy. Inclusion of clinic patients in this study nould probably not have el tered the picture very much. Fighty were incurable patients, 22 chronies. The three-reek survey made no such distinetion. In order to deterwine the number of chronic and incurable patients in Loulaville Goneral Hospital for whom chronic hospitalization or inatitutional care was necessary an attempt was made in the on o-day surrey to indicate those patients wi th no hom. A home was defined 
as "That residence of ther malntained by an individual, wife, or husband, or own child". Nine of the 22 ehronies, and 47 of the 80 Ineurables had no home. Iffty-six patients with no home conet Itated slightiy orer 50\% of the chronieally 11 l and incurable in the hospital.

Haring show that at lesst 276 persons (The ono-day surrey based on persons having no homes showed that at least 56 chronic and incurable patients needed special facllities but these cannot be considered as aditional to the patients in the three weeks group) need chronic hospitel or other institutional care, the Hospital sdrisory committee went on to atudy the existing facllities In Loulaville for chronic care, and concluded ite report by making several important recomendations. In sumberizad form, 1 ts findings rere: That the eity and county homes for the aged as well as the 16 homes conduoted by ahurches and affiliated groups and private corporations are caring for chronic and incurable imates without medical and nursing service; that there is noed in the cammuity of facilities for the care of pay, part pay, and free patienta ouffering Irom chronic and incurable diseases; that there is no proriation for the calored chronio and incurable patients; that there is lack of adequete rehabilitation service as a result of which the commanity is bullding up an umending b1ll in relle for chronie and incurable patients and their famil1es. With adequato rohabilltation serrice it is possible for many of the petients to beccue self-aupporting. Practically 50\% of the chronic patients in Iouistile Ceneral Hospital at the time of the study were under 40 years of age and $75 \%$ of then were males. 
The comittee recommended that a chronic hospitel be built as an extension of Iouisrille Ceneral Hospital where expert medieal and nursing supervision could be secured; that protisions be mede for pay, part pay, and free patients; that adequate soe1al aerrice, occupational therapy, and rehabilitation be developed; that the homes for the aged and other institutions develop moro adequate facilities; and that home care be continued where it is adequate to care for the neede of the patient.l

\section{Studr}

In July, 1937 Dr. Hugh Learall, C1ty Health Director, asked the Heal th Council to bying up-to-date the flgures of the chronic disease survey made in Loularille in 1927 to help to determine how large a hospital for chronic patients would be needed. Dr. Loavell stated at this time, at the present time no funds are avallable or in view for this purpose. Horever, Mayor Miller has asked that tentative plans for a chronic hosp 1tal bo made so that ho might pass the project on to his sucessaor. It is his idea that such study and plans should be made ready in case money might becane avallable Irom any souree. $n^{2}$

Lgein, onls ohronic disease patients fron low income groups Were enumerated, but exeluded from the study ware haves for the aged (beeause they elaim they do not accept people with a knom chronic condition), Loularille General Hospital clinics, Waterly Hills Clintc, and persons knom to the Public Health Nursing $15 s 0 c$ ia-

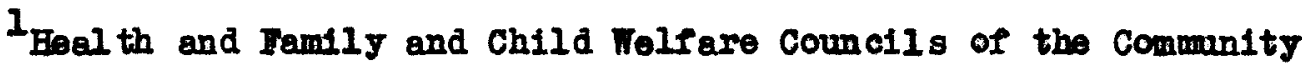
Chest. "study of the Provision far Chronte and Incurable Patients" Loutsoille, $\mathrm{Ky} \cdot 1927$.

\&Bulletin, Council of Social Agencies of the Louiarille community Chest. "Chronic IIIness in Lou1sville", No. 14, Oct 23, 1937 
tion. 4 chronic patient was defined as 4 person with any disease or ebnormal condition wich had necessitated $108 \mathrm{~s}$ of mosk, absance Irom school, or material change in normal activitios for a period of three months or more". This time the social agencies reported many more chronic patienta than in 1927 , probably due to more caraful study and case finding rather then an actual increase in the number of the chronically 111 .

$\triangle$ total of 1405 cases vere reported, 1000 by the varlous social agencies, 112 by the hospltals including General, and 293 by Home for the Aged and InfIrm, KIngs Daughters, Kosair, Ormsby Village, and Faverly Hills. The distribution of patients is shom in Table I.

of the 1405 chronia cases reported, 555 or $40 \%$ were recomminded for ehronic hospital care, and of this group 158 patients would require constent nureing care since many of then vere completely helpless. The rewaining 850 or $60 \%$ of patients could continue in their orm home. In 1927, 876 or $60 \%$ of total chronles were recommended for instituticnal care, therefore, there was a completo revercal in the 1937 findings. This might possibly hare been due to atrictor atandards used in 1937 in determining which chronto patienta need long time hospital care. Onder the supervision of clinics, c1ty physieians, and public health nurses many chronie pationts could rocelve adequate care at hone. The mumber of cases recomended for hospital caro varied considerably with the diagnoais. Mental abncrmality accomted for almost one-fourth of the cases. This corresponds alosely with the findings of the present study In which 21 of 76 chronic patients admitted to the Coneral Hospital 
BABLE I

CHRONIC CASES RRPORTED AS LIVING II

OWN EOMES, THPORARIIY IN GENERAL

HOSP ITALS, AND INSTITUTIONS FOR

LONG TIME CARE, LOUISVIII.F, KY. 1937

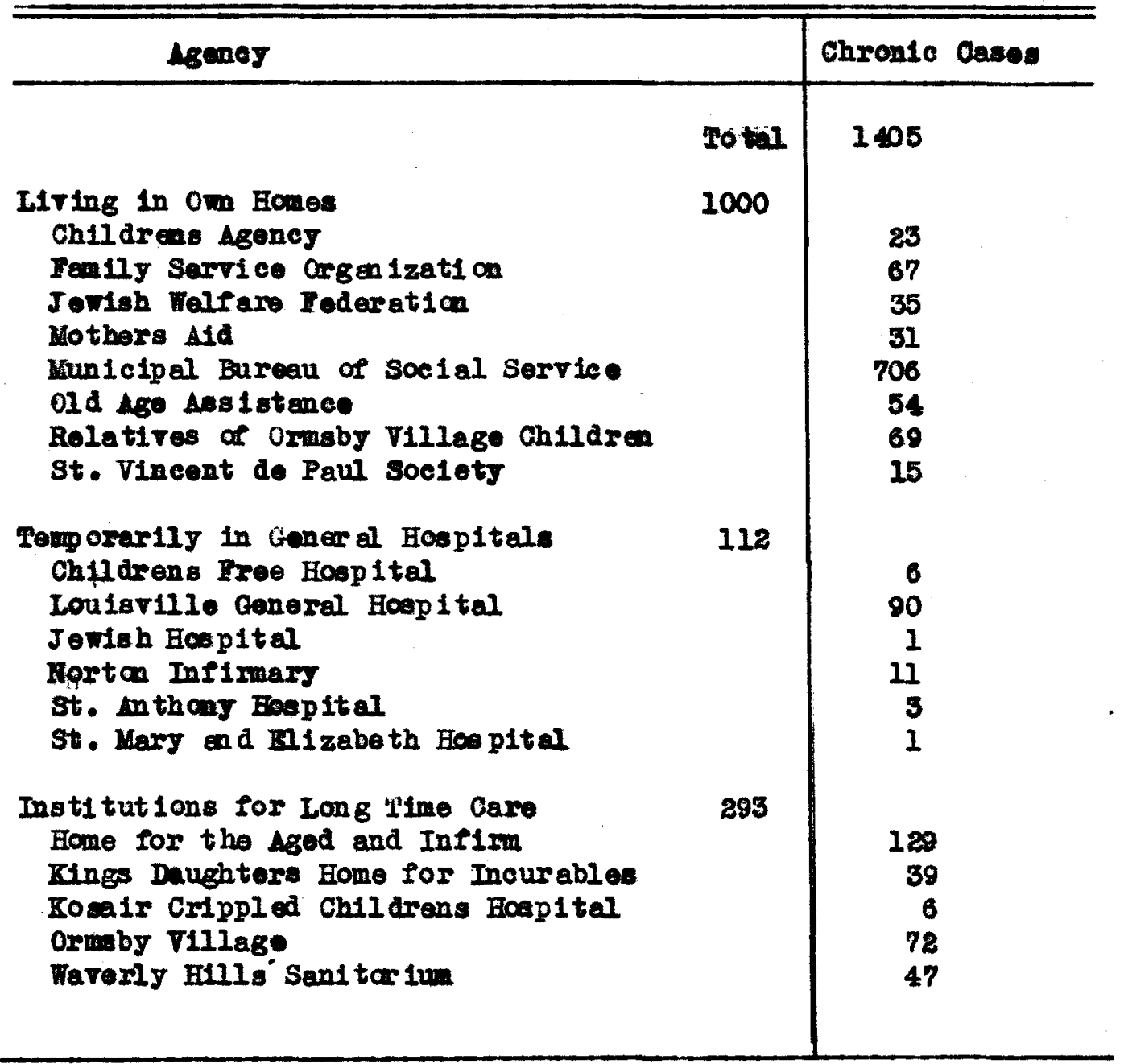

during a ten-day period were suffering from mentel disease. The phyaioelly orippled (arthritis, amputati ons, paralysis) in 1937 accounted for almost enother $25 \%$ of the chronic IIlnessess. Cardiac conilthns were enother b6\% of the total. (In the present study this Ilgare is much higher with $33 \%$ having cardiac conditions, but this Includes anemis and other diseses of the circulatory aysten 
which were counted separately in the 1937 census). Tuberculosis was enother $6 \%$, syphil1s $6 \%$, bliminess $6 \%$, and conditions making up the remaining $16 \%$ woro cencer, diabetes, nophritis, and othors.

It wa felt that half the mentel patients would be proper subjects for institutional care. W1 th the state ranotioning as oustodian for mental patiente requiring institut lonal care, the responsibility for the care of modical, orthopedic, and tuberculosis chronies is left to the elty. Based up on the findings of the 1937 surrey this wald loare 379 patients who should be accomodated in a city chronic hospital. of these $7 \%$ ware finito and $29 \%$ Negro; 197 were wales and 182 females. Of the total 1,405 chronie patients $51 \%$ were male, $49 \%$ fenale, $68 \%$ White and $32 \%$ Negro. Serenteen percent were under twenty-one years of age, and about 25\% were or sixty-five years of age. The New Yorik City survey and the Naticnal Heal th survey shomed a higher proporti on of chrcically ill in the younger age groups and forer in the older age grougs. In the present study of February, 1946, exoluding wental patients, coly seren percent are under the age of twentyOne and almost one-fourth are over the age a sixty-five. The number of White chronic patients and Negro ohronic patients is alnost the same, with only one White patient more than Negro. Fifty-four and one-half percent are males, $45.5 \%$ pemales. Louisville's study of 1937 showed caly three pereent cardiacs under the age trenty-one while in New York City 27\% of cardiacs were under sixteen years of age. About one-third of the cardiacs in each oity were crer sixty-five years of ag. Nen Yoxk City reported $40 \%$ of 1 its cardace in the normally active poriod of early adul thood end widdle age, whereas $67 \%$ of Loul orille's cardiac 
cases ware in this period.

New York City found that Negroes were five percent of its chronics, almost the same proportion as in its general population. Loulsville reported $37 \%$ of its chronics as Negroes, although they made up only $16 \%$ of the general population.

New York City's proportion of 10 income chronics to the population in 1933 was one in each 310 persons, excluding mental diseeses and tuberculosis. On a similar basis, Louisvilie's proportion in 1937 was one in each 371 persons. It is estimated that this group would comprise about one-third of the total number of chronics in the comnunity; the other two-thirds being unreported or financially able to take care of themselves. The ferer number of chronically 11 in Loulaville might be explained by better living conditions and warmer climate, but on the other hand it is more likely that there were scme unreported cases in Loufsille. Louisville reported a higher percentage of bedridden cases than New York. Forty-one percent of Louisville's hospital cases were bedridden. In the present study one-fourth of haspital patients, excluding the mentally ill, are bedridden. If the mentally 111 are included, the percentage is oven lower, $17 \%$ as none of these pationts are bedridden.

The recommendations of the 1937 study were:

1 - I tax supported chronic diseses hospitel to provide adequate medical oare for many patients suffering in their own homes. Such a hoapital would:

a. Relleve general hospitals of the care of low income chronic patients now occupying beds intended for acute cases and permit admission of more acute cases.

b. Reduce the per diem cost of care of chronic disease 
patients needing modicen care in a chronic institution. c. Provide better care for certain chronics than they can receive in their ow homes.

2 - A program of rehabilitation. While the city may be satisfied in prov lding merels modical, nursing, and custodial care for older chronics, there should be more constructive, educational prorision made for younger chronics who have a long lifo ahead of them.

3 - Conversion of the Home for Incurables into a voseti onal guidance institution for handicapped young people, and trensfer of the aging population of the hane to tex supported chronic hospital.

4 - A program of prevention. All social agencies, and particularly those admin ister ing reller, should encourage the groater use of facilities for health oxaminations in order that chronic disease mar be discorered in 1 ts earlier remedial stages.1

\section{Studies}

At the invitation of the Health Council and the Louistille Area Development Assoc lation, Dr. F. R. Bradley and R. B. Raper mede a preliminary survey of Loularille's hospital facilities to determine the need for expansion after the war, and reported their findings in Notember, 1945. Chron10 beds were derined as "Those given to the care of patients who are in elther the residual or terminal stage of a disabling or incurable disease who do not require active medical care and whose duration of stay ranges upward of six month". The question of ecostructing a

${ }^{1}$ Faines, inne, Chronic numeration. Louleville Health Council, 1937 
chronle or convalescent hospital in the Loularille area, as well as arranging for convelescent care with in the ins titutions alroady in existence was taken up. It was estimated that to moet the needs in the Louiaville area, at least 400 chronic beds nould be required. 1

Dr. 1. C. Bechmejer in June, 1945 survejed the facilities for the care of chronic diseeses and in January, 1946 a preliminary draft of his roport to the Compissioner of Health stated that 15\% of Louisville General Hospitel patients were in need of prolonged institutional care because of chronic disease. This finding was based on careful analys is made of the pationts in the hospitel on June 5, 1945. Forty-8even or 15\% were in need of prolonged institutional care. of these 19 were children (all but four vietims of poliomyelitis). The remaining 28 were classiIled into two groups; group $A$, those who with proper care can be restored to comparatively good health, or in other words, who can be rehabilitated sufficiently to permit their returen to their hanes and normal positions in the community; and group B, those whose disabilities are of permenent nature and who will require continued donielliary or custodial care. It was thought that 100 or more beds could readily be used for group 1 patients, and that the number of beds for group, B would rary according to the number of patients with a permanent disability but who also require medical and nursing care. Several hundred aditional beds would be needed for these patients. The two groups roughly

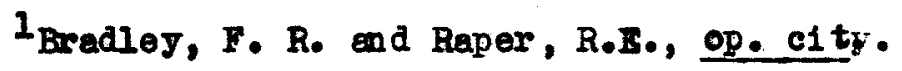


approrimate Boas' three classes, but they seen to be clesified according to degree of disability while Boas' clessification 18 based upon categories of modical noed.

The survey also makes reference to the data on nursing and convelescent homes collected by the Loulsville and Jeffersan County Health Department in the latter half of 1945. This material will be discussed in the chapter on resources for the chronically 111.1

\section{METHOD OF PRESENT SIUDY}

With this material as a background we shall now tum to the survey of 76 chronic patients adnitted to Louisville general Ho spital during the ten-day period, February 5 through February 14 in an endearor to learn what their problems are. The succeeding chapter will consider how the commity is equipped to help then.

The 76 patients studied were selected from the complete list kept by the record room of the hospital of patients admitted to the hospital during February 5 through February 14. The patients' neme and ward to which admitted were listed and it was, therefore, possible to eliminate some of the cases at a glance, by ward. Patients in obstetrical and Isolation Fards were imediately discarded as were those who had died, al though scme of the latter might have been chronle patients. The diagnosis ves not know at th is point. The fire patients who died during the couras of the study were included in the total caser.

$I_{\text {Bachmeyer, A.C., op. eit. }}$ 
Also axiluded rere patiento treated in the new federally casstructed and financed Iffy-bed rapld treatment center located in the hosp 1 tal.

The el imination of obstetrical, isolation, and repid treatmont wards and decesed patients left the medical, surgical, baby, and psychiatric wards to be surveyed for chronic patients. At the beginning, the medical rocords of all these patients were carefully studied but due to the large volume of records this proved to be a costly procedure in terms of the examinem's time and the ti we of the record room staff who pulled the records, and this mothod had to be abandoned.

A card for each patient adnitted to the hospital, containing the provisional diagnosis in adition to other factual data was avallable in the social service department and by use of these cards the obvious acute cases could be el ininated, leaving those with a definite ar possible chronic condition. Further definitia as to chronleity, considering other factors such as duration and Incapacity, besides diagnosis was then obtained by careful study of the medical record, in the first method, for those patiente suspected of being chronic. Fad it been feasible to comple te the case finding by means of the first mothod, in other vords, to have studied each medical record, possibly more chronic cases rould have been found than the 76 included in the study. The diaposis on the cand may, in some instances, have indicated only the acute manifestation of the chronic condition, but not the contributing chronic cause. Gengrene of a limb, for example, may 
have been disearded as acute condition, when a stady of the : modical chart might have revealed a patient with a diabetic history of sereral years duration. In other instances, hoverer, the notation on the chart read "Gengrene of right foot--diabetic".

In the orfinal sereening process undiagnced cases were also discarded although upon further investigation these might also have proved chrcale. Only the medical records of the patients alreaty disoharged at the time of the study were on Iile in the record room, having been sent there from the ward after the patients discharge. Medical records are always kept in the rard when the patient 10 in the hospital and theoe reords, for the patients still in the hospital at the time of study were arallable there. To determine chronicity, an interview with the doctor or nurse was more revealing than were the records, and this was done whenever possible. Conditions whleh could be eured by surgery or which were not vexy incapacitating, such as hemorrholds, hernia, chronic tonsillitis, keratitis (Inflammation of the comea of the eye), chronle appendicitis, sheunat lc fever inactive for a long period of time, and certain of the grnecologicel conditions, were discarded.

It was perticularly difficult to distinguish between the acute and chronic among the egnecological conditions, and individual cir cunstances had to be carefully considered in each case. The most common gynecologieal conditions are chronic salpingitis, endometrial hyperplasia, fibrold uterus, cancer of the cervix, chronic ondonetritis, and chronie cervie1tis. Chronie selpingitis is most common in young Negro wonen in the 10w income groups and is caused by an early gonorrheal infecticn. Its course alrays seems to follow the same 
dorelopment: en acute attack of pelvic inflammatory disease which often goes untreated because it is not so serero as to keep the victin away from her job, followed by ether attack with fever that causes the patient to seek medical advice, at which time the doctor may preseribe aulathiazole and discharge the patient because examinatia fails to show any abnormality. Anytine fran six month to three years later a thiokening of the internal genitalia takes place followed by repeated attacks with evere pains in the side. Finally the pain becomes so arem that the patient cannot work and at this time the physician may recommend surgery when the condition is not in the acute tage. The condition is chronic in that it is not self-limiting but follows a slowly progressive course leading to frequent incapacitation. The inflametory adhesions alfays remein in the pelvis and may be revived by chlldbirth, gonorrheal reinfection, and other things. On the other hand, this patient may be able to work between attacks and may tell you that she is feeling $P$ ine.

Fibrold uterus or liongoma is nother condition occurring Irequently among Negro women which often goes untreated for years. It is an excessive growth of the wall of the uterus. Fndometrial hyperplasia, a glandular condition, is an overgrowth of endometrium which may be treated by ovarian extracts and thyroid to secure endocrine balance, and also by surgieal means; dilation and curettage to scrape out the wall of the uterus. Such a condition may cause great social enbarrassment, aue to the excessive loss of blood, it witen precipitates an anemic condition. Cancer of the cervix is a serious condition with poor prognosis for recovery if radicel surgery involving 
remoral of the entire internal gonitalia and lymph glands is not done early, after the diagnosis has been confirmed by biopsy. Without such treatmont the patient may die within three to fire years artar the condition derelops. Radium and Iray therapy are also used in treatment. Treatment is often neglected berause the pationt frem quently ignores the early min or symptoms of burning; constipation, etc. and is often unaware of the condition. At a later stage nothing can be offered the patient besides sedation. Constent nursing care, or class B care, is extrenely important for the comfort of the patient and should be continued until death. Chronie endometritis is a 10w grade chronic Infection which may be treated wh penieillin. and like chronic cervicitis, an erosion ar chronis infection of the glands of the cervix, causes 11 tt le trouble.

It can be seen from the brier foregoing deseription that grnecological conditions range from those that cause some discomfort but little incapacity, to those which almost ineritably result in death. In the present study three grnecology cases are Included; chronic salpingitis, endowetrial hyperplasia, and pelvic inflammetcry disease (a form of salpingitia). A case of carcincma of the cerris with metastasis is included under the disease groupIng "canoer and other tumors" as shove in Tablo 2. This patient had had throe previous adn issions to General Hospital since JulJ of 1945, this being her fourth. Far prognos is wes "very poor". A cerviceotcon had been done, and radium treatment given.

Patients admittod to the psychiatric wards had varied diagnoses, all of which are considered chronic. These patients present a different planning problem from those on the medical and surgical 
CERONICATLY III PATIENT' ${ }^{2}$ ADITHSD TO

LOUISVIILF GEHERAI HOSPITAI, FIBRCLRY 5th

HEROTGH FEBRUARY 14th, 1946 by

DIAGNOSIS AND PERCEVT

\begin{tabular}{|c|c|c|c|}
\hline & $\begin{array}{l}\text { Dies } \\
\text { Primayy }\end{array}$ & $\begin{array}{l}\text { nosis } \\
\text { secondary }\end{array}$ & $\begin{array}{l}\text { Percent } \\
\text { (prlmary } \\
\text { diagenosis }\end{array}$ \\
\hline $\begin{array}{l}\text { Total } \\
\text { Dpldemic and Communicable } \\
\text { Poliomyelitis } \\
\text { Pulmonary Tuber culosis } \\
\text { Non-Pulmonary Tuberculosia } \\
\text { Venereal Dasease }\end{array}$ & $\begin{array}{ll}55 & \\
4 & 1 \\
1 \\
1 \\
1\end{array}$ & $\begin{array}{l}13 \\
2\end{array}$ & $\begin{array}{r}100 \\
7\end{array}$ \\
\hline 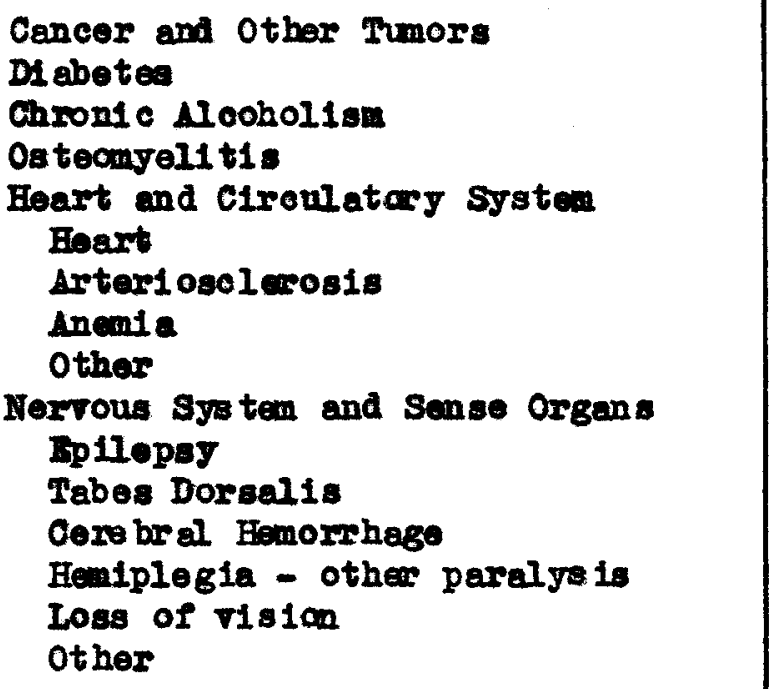 & $\begin{array}{rr}5 & \\
4 & \\
1 & \\
4 & \\
18 & \\
& 14 \\
& 1 \\
& 2 \\
& 1 \\
& \\
6 & \\
& 1 \\
& 1 \\
& \\
& 0 \\
& 2 \\
& 1 \\
& \\
& \end{array}$ & 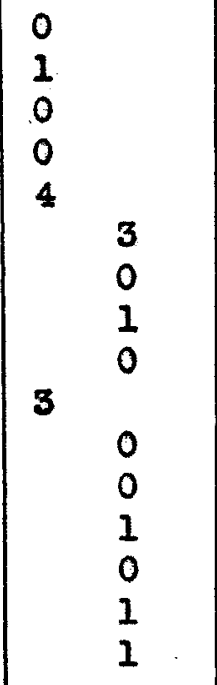 & $\begin{array}{l}9 \\
7 \\
1.5 \\
7 \\
33\end{array}$ \\
\hline 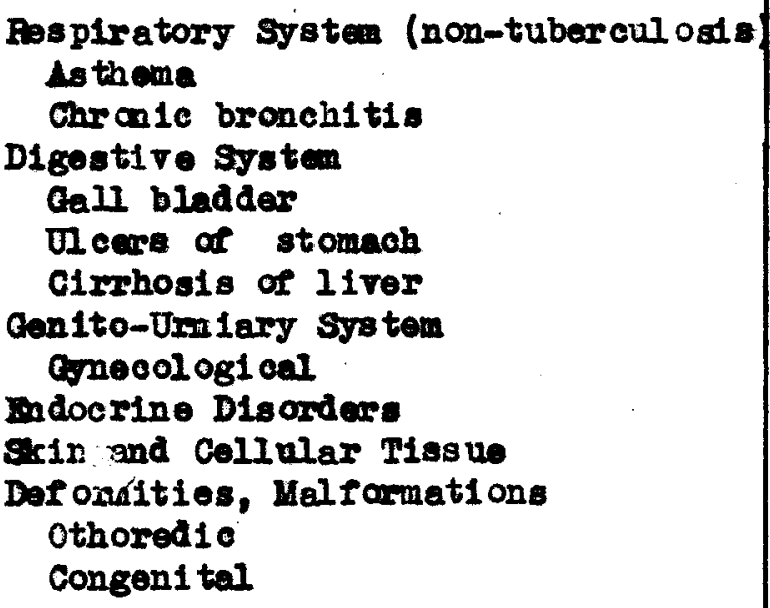 & $\begin{array}{ll}2 & \\
& 1 \\
3 & 1 \\
& 1 \\
& 1 \\
& 1 \\
3 & \\
& 3 \\
0 & \\
1 & \\
4 & \\
& 2 \\
& 2\end{array}$ & $\begin{array}{ll}0 & \\
& 0 \\
0 & 0 \\
& 0 \\
& 0 \\
& 0 \\
2 & \\
1 & 2 \\
0 & \\
0 & \\
& 0 \\
& 0\end{array}$ & $\begin{array}{l}6 \\
0 \\
1.5 \\
7\end{array}$ \\
\hline
\end{tabular}

axaluding Patients on Peychiatric Faxds 
waris, since a mental institution and not a chronic hospital is indicated for their care, but they were included in order that a statistically correct picture of all chronle patients admitted to the hospital during tius ten-day period might bo prosented. $\triangle$ schedule (se0 Appendix 1) for these patients wes not filled out, and they were not interviewed in the wards or at home as were the others, but inste ad information concerning their diagnosis, prognosis, condition, end disposition was secured from one of the resident physicians in psychiatry. Financlal data was secured, as for the other patients, from the admissions office. Iplleptlc pationts are included in this group with the exception of one epileptic who was acmitted to the medical ward. The difference is that the former have epilepsy with psychosio.

The social service files, and interviews with the social workers in the medical, surgical, orthopedic and pediatric services supplied information on the number of patients know $n$ to the soeial service department and hat the contact had been.

After the cases had been selected, they were divided into two groups; those atill in the wards, and those discharged to their home or place of residence. The medical record of each pationt was gleaned for necessary information, a doctor was intervi ewed for each patient atill in the ward for conflrmation of diagnosia, pationts condition and prognosis, end recomendations concerning the kind of medical care the patient requires and where such care should be secured. An attempt was made to interviow each pationt in the warts. In a few instances it was not possible to talk with the 
patient because he was either too sick or was incoherent, or had lost the power of speech following paralysis. Thenever practicable a relative was seen instead. Home visits were made to the remaining patients and to the relatives of children patients, except those living in institutions or outside the eity limits, and relatives were interviewed when the patient was not at home. Telephone calls were made to secure information on the two institutional cases who had been diecherged, one at the Home for the Aged and Infirm, the other at the Kings Deaghters Hane for Incurables. (Two inmates of the Home for Incurables were still in the wards). A letter contained in Appendix 3, incorporating a coe of the questions corered in the schedule was sent to the fire patients living outside the city limits. One reply was received. THE NOMBER OF CHRON ICALLY IIL

There were 440 patients einitted to Louisville Gener al Hospital Iram Pebruary 5 through February 14, 1946. Of the total, 76 or more than one-sixth were chronically 111. In the 1927 study $17 \%$ of ward and clinic patients over a three-week period were found to be chronically 111 and $26.2 \%$ of rard patients studied on a single day. In 1937 the hospital reported a proportion of about one in erery I1ve patients, or 20\%. Dr. Bacheyer's study in 1945 revealed 15\% of patients in need of institutional care because of chronic 111ness. As not all the chronically 111 need institut ical care, we can assume that the actual number of chronically 111 was eren higher then 15\%. The one-day surrey in 1927 found that $50 \%$ of all chronically 111 need institutional care. Figured on a similar basis, the actual proporti on of chronically 111 in General Hosp 1 tal during June 1945 was $30 \%$ of total patients. The present sigure of more then one- 
sixth or about $17 \%$ is lower then that of previous studies. There are fever chronic patients in Louisville General Hosp 1 tal than there Wore chronic patients occupjing ward beds in the hospitals in Ner York City in 1928. In Lou1grille the Ifgure is one out of every six patients; in New York City the proportion was one out of erery Ifre pationts.

SEX AND RACE

of the total patients excluding the psychiatric thirty or $54.5 \%$ were males, twenty-five or $45.5 \%$ were females. Of the tot al 1,405 chronic patients in the 1937 study $51 \%$ were male, $49 \%$ femel $\theta$. The number of White and Negro patients aro almost the same, 28 and 27 respectivelJ, with only cue White patient in excess of Negro. New York C1ty reported a small number of Negroes anong its chronic cases, only five percent of all ceses, but this wes in proportion to 1 to population. In 1937 Louisville reported $37 \%$ of 1 ts chronics as Hegroes, or twice as many as the proportion of its Negro population. This figure is even higher in the present study with $50 \%$ of all cases being Negro. Approximately $15 \%$ of the entire Louist1lle population in July 1944 wore Negroes. Poor housing, poor food and poor Ilving conditions in generalmight easily account for the excessive rate of chronic illness among the Negro population. As s bow in Table 3 It is significant that 11 of the eight heart and cireulatory conditions occurred among the Negro patients and all of the gynecological ceses including carcinoma of the cervix were anong Negroes. Three out of four ep 1demic and communicable disesses were anong negroes. This disesse group includes poliomyelitis, tuberculosis, and venereal disease. The rate for diabetes, ostecmyelitis, and disesses of the 


\section{TABIS 3}

CHIEH DISEASE GROUPS OF CHPONICALLY ILC PATIENTS ${ }^{a}$ ADMITTED TO LOUISVIIIE GENERAL HOSPITAL FFBRUARY 5th THROUGH FEBROARY 14th, 1946 BY RACE

\begin{tabular}{|c|c|c|c|}
\hline \multirow[b]{2}{*}{ Disease Groups } & \multirow[b]{2}{*}{ Totel } & \multicolumn{2}{|c|}{ Race } \\
\hline & & Finite & Negro \\
\hline Total & 55 & 28 & 27 \\
\hline 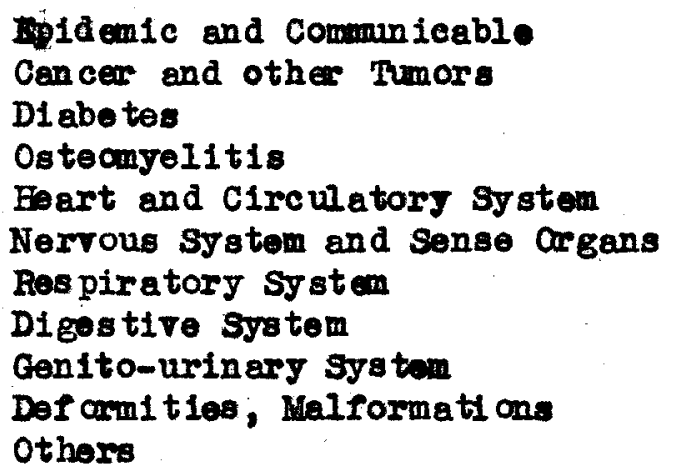 & $\begin{array}{r}4 \\
5 \\
4 \\
4 \\
18 \\
6 \\
2 \\
3 \\
3 \\
4 \\
8\end{array}$ & $\begin{array}{l}1 \\
4 \\
8 \\
7 \\
4 \\
1 \\
2 \\
0 \\
4 \\
1\end{array}$ & $\begin{array}{r}3 \\
1 \\
8 \\
2 \\
11 \\
2 \\
1 \\
1 \\
3 \\
0 \\
1\end{array}$ \\
\hline
\end{tabular}

\section{TABLE 4}

OCCUPATION OF CBRONICAJLY IIL PATIENRS ${ }^{\circ}$

ADITTISD TO LOUISVIILE GENERAL HOSPITAI FEBRUARY 5th THROUGH FRBRUARY 14th, 1946 BY RACL

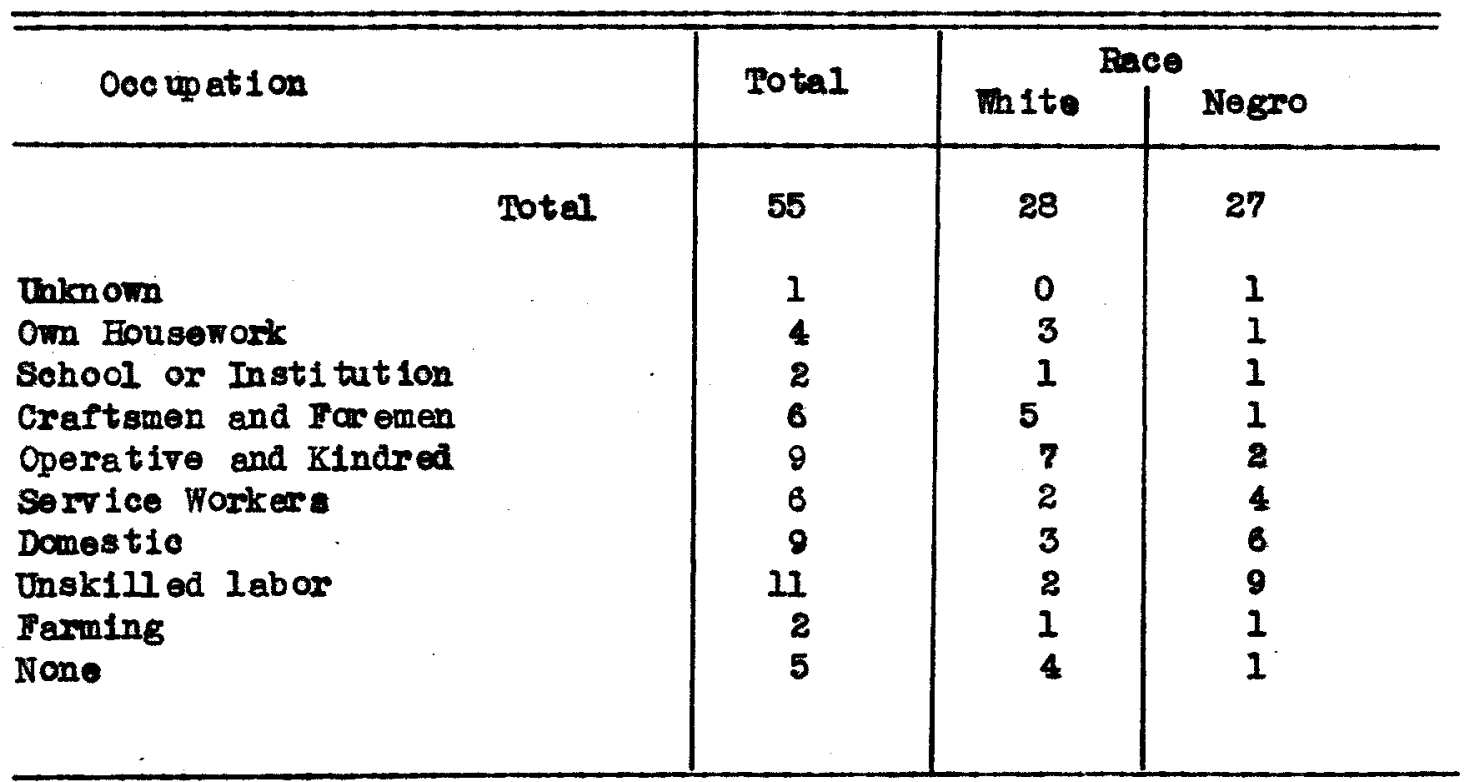


respiratary aysten was the same for both Negro and White. White patients had more cancer, conditicns of the nerrous system and sense organs, diseases of the digestive system, and deformitien and malformations than did the Negroes as shown in table 4. Onethird of the Negroev were last employed as unskilled laborers, and the next largest number were domestic workers. Only two of the White patients were unskilled laborers as against nine Negroes doing this type of work. Thare were twice as many Negro domestics as there were White domestics.

The median agel of the 55 patients exclualve of the paychiatric patients was 43.5 years. The youngest patient was five years old, the oldest ofghty-seren years of age. Both suffered a heart disease,

\section{TABTLS 5}

AGS OF CHRONICALLY IIL PATIENTS ${ }^{\circ}$ ADMITIED TO LOUISVIIJTH GENERAL HOSPITAL FEBRUARY 5 th THROUGH FEBRUARY 14th, 1946 BY SIEX, RACF, AND MARITAL STATUS

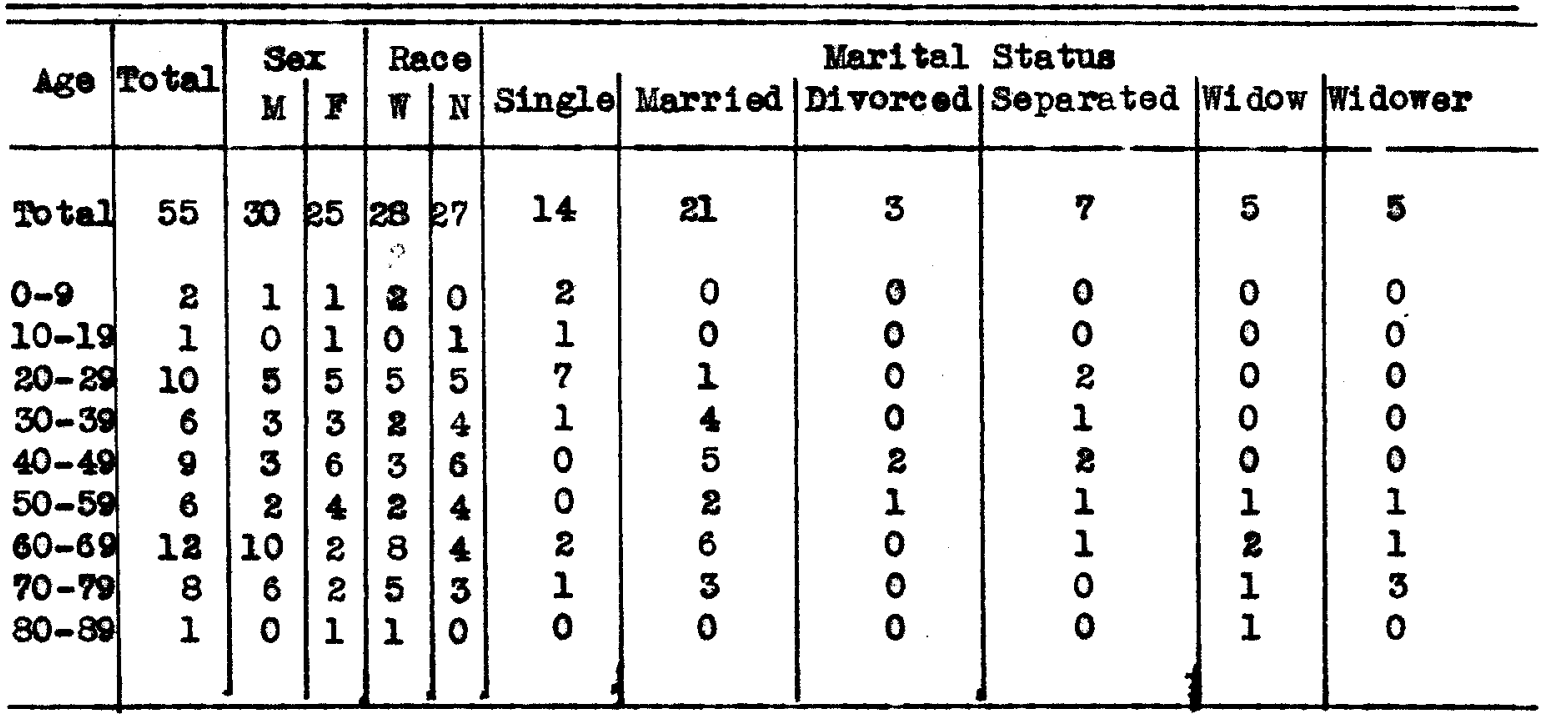

Arcluing patients on Psychiatric mards

${ }^{1}$ The median average is used throughout this study except otherwise indicated. 
the fire-year-old rhounatic heart disease and the eighty-seren jear-old hypertensire cardio rascular disese. As ghown in Table 5, more than one-fifth of the ohronic patients were between the ages of 8 ixty to sixty-nine jears, and about $18.5 \%$ were between the ges of twenty to trenty-nine. Seven percent of the patients wero under twenty-one years of ege and almost cne-fourth were orer the age of sixty-five. In other studies, including the National Health Survey, the New York C1ty study of 1928, and the Louisville study of 1937, the proportion was higher for the lower age groups and lower for the higher gge groups. The Louisville 1937 study showed $17 \%$ under the age of twenty-one and about $25 \%$ orer age sixty-five. Dr. Baokmeyer's study of General Hospital patients on June 5, 1845 reveal ed 19 cases of ahronic disesse among children but 15 of these vere poliomyelltis vietims. Loulsville had had an epldemic of polio myelitis between Mey a December of the previcus year and this would probably account for the excessive number of pollomyel itis cases in the wards at this time.

MARITAI STATUS

The greatest number of the chronically 111 patients, about $38 \%$ excluatre of the psychlatric, were merried. About one-fourth were single, and half of this number, $12.5 \%$ were separated as shom in Table 5. Almost $6 \%$ were divarced. The same number ware widows as wre widorars, nine percent. A knowledge of the marital status of the chronioally 111 is meaningful when examined in terms of howe reaponsibility and effect upon health. It is safo to assume that the married pationts had not on $1 y$ themselves to look af ter but also a martal partner and sometimes children. Of the il married patients, 
16 ware men and fire were women shom in Table 6 . All of the males hed same gainful occupation and at least five had worked outside the home up until the present hospital adnission. Others TABLA 6

MARITAL STATUS OF CHRONICAILY IIL PATIANTS ${ }^{a}$ ADMITIED TO LOUISVIIIUS GEVERAL HOSPITAL FEBRUARY 5th THROUGH FEBRUARY 14th, 1846 BY SET

\begin{tabular}{|c|c|c|c|}
\hline \multirow{2}{*}{ Marital status } & \multirow[b]{2}{*}{ Total } & \multicolumn{2}{|c|}{ Sex } \\
\hline & & Malo & Female \\
\hline Total & & 30 & 25 \\
\hline $\begin{array}{l}\text { Singlo } \\
\text { Married } \\
\text { Diroread } \\
\text { Separatod } \\
\text { Fid on } \\
\text { Wid ower }\end{array}$ & $\begin{array}{r}14 \\
21 \\
3 \\
7 \\
5 \\
5\end{array}$ & $\begin{array}{r}8 \\
16 \\
0 \\
1 \\
0 \\
5\end{array}$ & $\begin{array}{l}6 \\
5 \\
3 \\
6 \\
5 \\
0\end{array}$ \\
\hline
\end{tabular}

arcluding patients on psychiatric wards.

were living on public assistance. Several had applied for public assistence since leaving the hospital. The responsibility for support of the family rested with the man who was the head of the femily except in a for instences where the wife was in remunerative omployment. In fourfifths of the total of 55 cases, the income was derivod from the patient himself, whether in the form of earnings, savings, Insureace, public assistance, etc. and the proportico wald be eren highor for married males. These wore comparatively few children to be taken care of. Only those patients with children in the hane or 
rery much in the picture (1.e. contributing to the patients' support or helping in other ways) were recorded. It was found as show in Table 7 that 34 of the 55 patients had no children at

\section{TABTE 7}

\section{HOUSING OF CHFNICAILY IIL PATIRNTS ${ }^{A}$ ADMITHTED \\ TO LOUISVILIE G GNERAI HOSP ITAL FEBRUARY \\ 5 th THROUG FEBRUARY 14th, 1946, BY \\ NOMBER II HOUSEROLD AND NUMBER OF CHITDRRYY}

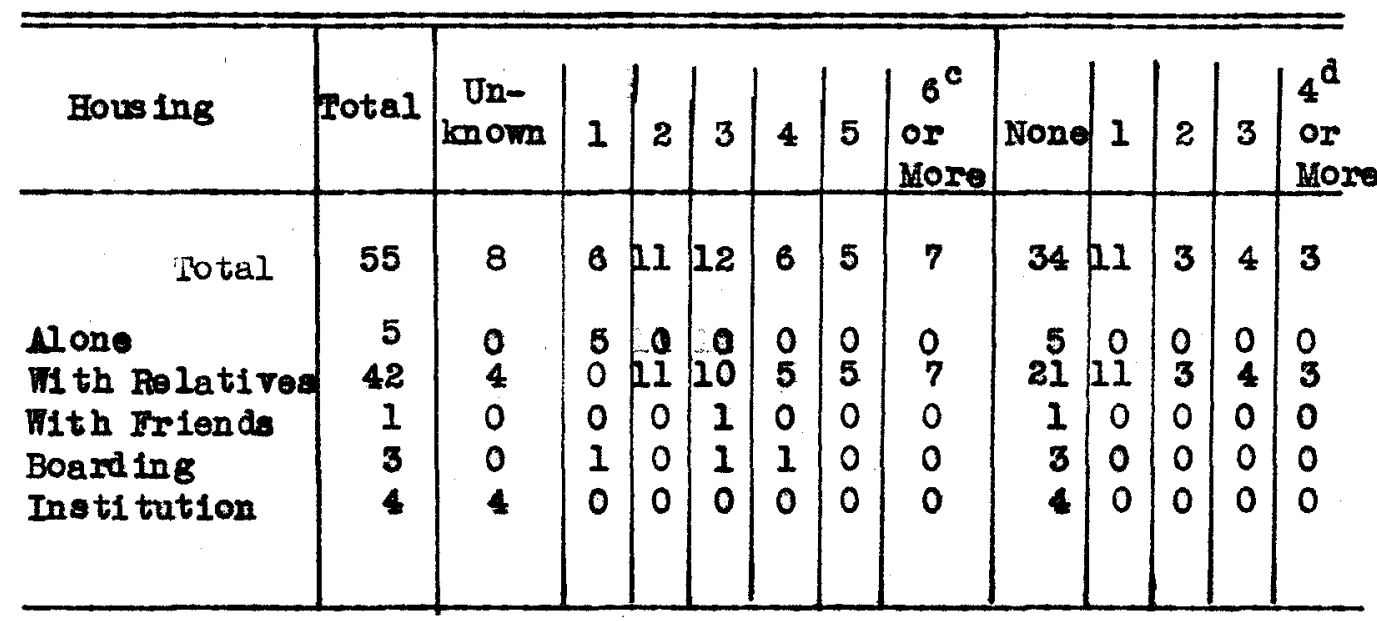

Excluding patients on psyehiatric warda.

biving at home or very much in the picture

'Ono patient lived in a hous ehold of twelve people

done patient had ten children

home or in the picture, Il patients had cos child, and one patient had as many as ten children. The age of the children was tabulated but there is nothing olgnificent in the findings. A great wany patients had grown chlldren who were married and out of the hane and who were, therefore, not tabulated. The picture, then, is of a great many more married men than women pati ents who here wives 
but not ch1ldren to support and to whom in all $11 \mathrm{kl}$ ihood the support of the femily comes before their own physical needs.

of the five married nomen patients, two were employed outside the home just prior to the present hospitalization for the pertial support of the family, and the balance rere supported entirely through their husbands' eamings. It is significent as shom in Table 4 that the number of women (of all rital status) who did their om housework were few, only four out of 85 or about one-sixth. of the remainder, some had not been employed for rarying periods of time due to 1llness, others had been Invallds for many years and had never been enployed ei ther inside or outside thelr hanes, but the belance were working outside the hane as donestics, in laundries, etc. At least seven females were employed outisde the home up until the time of the present admissico. The two married women wo were employed outside the hame were domestice. One of these romen had ten children. It is not surprising that hor medical diagnosis was hypertensive cardio vasoular disease, for the triple job of caring for some else's household as well as her orm, and seeing to her ten children would be a strain upon anyone's heart. Excessive family responsibility in itself is serlous where there is chronic 1liness, but nnfarorable oconomic circumstance added to it makes for an impossible aftuation. Unfarorable econonic circumstances mar precipitate the chronic condtion, but 1 is is more 11 kely that porerty 1. brought on as a reault of chronic incapacitation. When the man is the chronic disease sufferer the wife may be tom between the need to remain at hane to care for him, and the equally urgent need 
to seek employment outside the home to of fset the costs of the 11lness. The situation is serious when chronic illness affects the chief rage earner but equally se rious when the wife is stricken, in terms of disorgenization of the household, neglect of chlldren and various other products of illness.

Bowerer, difficult as it may be for two people to combat the hatiships of chronic lliness, it is even more of a problem for the Indidual who has no marital pertner; the single, dirorced, separated, the widow, and the wdower. Other relatives, such as parents, y be helping but there is a limit to what they can do. The widors and widowers often live with a grown child who has a family of $h$ is own and it is not uncommon to find the parent making his hone with several different children during the course of a year. Femily relationships are atrained as a result of the varicus personal services demended, the additional financial burden, and the crowding, (as shown in Table 8, the ararage number of occupants per household was 2.8 whlle the arerage number of rooms was 2.4, ) arising from haring a chronic invalid in the home. The situation is equally unpleasant for the patient and for the relatives. The petient may not be getting the kind of care his illness cells for but on the other hand, the children ma not be equipped to give better care.

Of the ten widored petients, seren were living in the household or their children, cone was on institutional case, and two maintained their own homes. One of the seren living of th a child had lived alone prior to this haspitalization, but she planned to convalesce at her daughter's home upon discharge. Another patient had IIred alternetely with a sister and with his daughtor's family, and plenned 


\section{PABLE 8}

HOUSING OF CHRONICAILY IIL PATIRNTS ADMITTED

TO IOUISVIITLE GENERAL HOSP ITAL FEBRUARY

5th THROUGH FEBRUARY 14th, 1946, BY

NUMBECR OF ROCAS, WHETHER ROOM TO SETT, SLEASPING ALONE

\begin{tabular}{|c|c|c|c|c|c|c|c|c|c|c|c|c|c|c|}
\hline \multirow[t]{2}{*}{ Fousing } & \multirow[t]{2}{*}{ Potal } & \multirow{2}{*}{$\begin{array}{l}\text { Un- } \\
\text { knomm }\end{array}$} & \multicolumn{5}{|c|}{$\begin{array}{c}\text { Number of } \\
\text { Rocms }\end{array}$} & \multirow{2}{*}{$\begin{array}{c}6 \\
\text { or } \\
\text { tore }\end{array}$} & \multicolumn{2}{|c|}{$\begin{array}{l}\text { Room to } \\
\text { Self }\end{array}$} & \multirow{2}{*}{ No } & \multicolumn{3}{|c|}{$\begin{array}{c}\text { sleeping } \\
\text { Alone }\end{array}$} \\
\hline & & & 1 & 2 & 3 & 4 & 5 & & $\begin{array}{c}\text { Un- } \\
\text { known }\end{array}$ & Yos & & $\begin{array}{c}\text { Th- } \\
\text { known }\end{array}$ & Yes & No \\
\hline Total & 55 & 18 & 7 & .7 & 12 & 8 & 3 & 5 & 13 & 26 & $16 \mid$ & 9 & 33 & 13 \\
\hline $\begin{array}{l}\text { Alone } \\
\text { ith Relatived } \\
\text { Fith Priend: } \\
\text { Boarding } \\
\text { Institut } 1 \text { on }\end{array}$ & $\begin{array}{r}5 \\
42 \\
1 \\
3 \\
4\end{array}$ & $\begin{array}{l}0 \\
8 \\
0 \\
0 \\
4\end{array}$ & \begin{tabular}{l|}
3 \\
1 \\
1 \\
2 \\
0
\end{tabular} & $\begin{array}{l}1 \\
6 \\
0 \\
0 \\
0\end{array}$ & $\begin{array}{r}0 \\
12 \\
0 \\
0 \\
0\end{array}$ & $\begin{array}{l}0 \\
0 \\
0 \\
0 \\
0\end{array}$ & $\begin{array}{l}1 \\
1 \\
0 \\
1 \\
0\end{array}$ & $\begin{array}{l}0 \\
5 \\
0 \\
0 \\
0\end{array}$ & $\begin{array}{l}0 \\
9 \\
0 \\
0 \\
4\end{array}$ & $\begin{array}{r}5 \\
17 \\
1 \\
3 \\
0\end{array}$ & $\begin{array}{r}0 \\
16 \\
0 \\
0 \\
0\end{array}$ & $\begin{array}{l}0 \\
9 \\
0 \\
0 \\
0\end{array}$ & $\begin{array}{r}5 \\
20 \\
1 \\
3 \\
4\end{array}$ & 0 \\
\hline
\end{tabular}

arreluding patiento on porchiatric varda

to return to the home of his sieter because the daughter's home was so crowied; nine people living in three rocms. This very amiable old man, age 75, with cancer of the rectum stated that his daughter's howe was crowded and nolsy os she had six young children. Living with the infirm sister, ninety-one, did not seem to be a meh better solution as the patient was of ten in the position of having to help his sister while his own needs went unattended. Another petient, a widor suffering two chronic conditions, eholecyotitis ond diabetes mellitus, I1red with a danghter wo had six children of hor own. The oldest patient, a midor aged eighty-seren, I1red with a daughter and three children but the daughter was employed outside the home and the patient, feoble and suffering from heart disease, cared for the three ch1ldren.

The problew of getting the children to support their parents was 
not an important factor with these patients athough it of ten arises anong relief agency clients. Four of the ten widow pationt were receiving ald age grants and one hed applied for Municipal Burean of Social service assistance upon leaving the hospital. These patiente were, therefore, not entirely economically dependent up on their children but with grants being between 10 and 19 a month it can be seen that a pood deal of supplementati on by the children was necessary. Ilaces all of the separated and diroreed patients were women. All three of the dirorced patients were women, and six of the seven who had separated from their spouse were women. This leads us to wonder whether the chronic condition had been instrumental in causing ruture of the family ties, and if there is anj correlation between marital happ iness and the health of the marital partners.

The Ananoial problems of the separated and dirorced patients especially beoause they were nearly all women, were more serious then they vare anong the married and single patients. Two of these patients were employed prior to the present hospitalization, one as a cook, the other as a switchboard operator. One wanan patient wes an Institutional case, and mother recelved putlic assistence. One patient was being supported by a friend, and the remainder by relatires. Wone of the diroreees hed been granted support by the terms of the dirorce, and the husband of on waman contributed occalcally to the support of $h$ is wfe from whom he was separated. There ware eight single male patients as against six female pationts. Most of these patients were unmarried by virtue of age, the median age being twenty-f1re. More then one-fourth were under the age of twenty-one. Three patients aged sixty-five end over had never married, and were not employed, all receiving public assistence. of the younger age 
group only three were enployed outside the home just before hospitalization. One had been in service and was receiving a disability pension, two were children (one living with grandparents, the other With parents who received public assistence). Two wero institutical caser. The remaining three were being supported by relatires. Chronic 11lness occurring curing the early productive years is a particularly sorious problem. Adjusting to a prolonged, incapacitating disease is difficult at any age but especielly when the individual is in young adul thood and the 11 lness 111 be of moch longer duration than are the 11lnessess of the present aged populaticn. Too, they aro potentially of greater expense to the community. The young unmarried patients in this study were suffering from ankylosis of the wrists, knees, and ankles, a congenital deformity, chronic hepatitis, diabetes, polianyelitis with atrophy of almost all of the muscles of the body, chronte pelvie inflamatory disease, chronic alpingltis, ond cmetrial hyperplasia, chronic alcoholism $\frac{1}{3}$ rheumatic heart disease, a ecngenital orthopedic condition, and ostecmyelitis. One of these pationts had been inatitutionalized for 17 years, other for three years. The posibility of courtship, marrioge, and having a family of their orm seans very remote for most of these patients. Rheumatoid arthritis, not represented in this study, is enother disese which occurs most Irequently anong young adults with erippling effects. Deformity which can often be ererted by early adequate treatment of ten becomes progressively woree 11 untreated, causing a good deal of fear, anxiety and unheppiness.

DIAGNOSIES

By far the largest number of chronically 11l, almost half, were

IThis patient was in the Medical Ward, With secondary diagnosis of bronchopneumonia. 
found in the medical rards. The psychiatric were the next largest group, making up orer one-fourth of the total 76 patients. There were 17 patients ar loss than one-fourth in the surgical wards and only two patients cre about three percent in the baby wards as shown in Table 2.

Nmost cue-fourth of the mental cases were suffering from a farm of paychoneurosis and the next largest group in numerical importanee were the achizophrenies. Nanie depressive peychosis, arterisclerosis, (generalized and cerebral), and senilo psychosis each claimed two persons, and the remaining c cnditions, involutional melancholla, Korsakorf's psychosis, epil epsy, alcoholism, Irontal lobe remoral, conduct disturbance, end mentel deficiency were each experienced by one patient. The primary diagnosis, therefore, ren the mole gamut of mental disease, from psychoses to mental defictency as shom in Table 9.

Psychopathic personality was not a primary diegnosis in any of these cases, but in two individuals accompanied enother condition.

The diagnoses of the medical, surgioal, and baby ward patients is dirided into jor disesse groupings; epidemic and commuicable, cancer and othor tumors, arthritis and rheumatism, diabetes, chronic alcoholism, osteangelitis, heart and circulatory systen, nerrous system end sense organs, respiratory system, digestive systen, genito-urinary system, endocrine disorders, skin and cellular tissue, and defarmities and malformations. In table 2 they are further broken dom into the speific disesses that comprise the chlef disease groups. Fifty of the total diagnoses were confirmed; five ware pror is ional or 
TABLE 9

DIAGNOSIS OF PATIZNTS IN THE PSYCHIATRIC WARDS

AIMITIED TO LOUISVIILS GENERAL HOSPITAL

IFBRUA RY 5th THROUGH FEBRUARY 14th, 1946,

BY CONDITION, PROGNOSIS, AND DISPOSITION

\begin{tabular}{|c|c|c|c|}
\hline Di egnosis & Total & Monol atory & $\begin{array}{l}\text { ition } \\
\text { Partially } \\
\text { Ambulatory }\end{array}$ \\
\hline 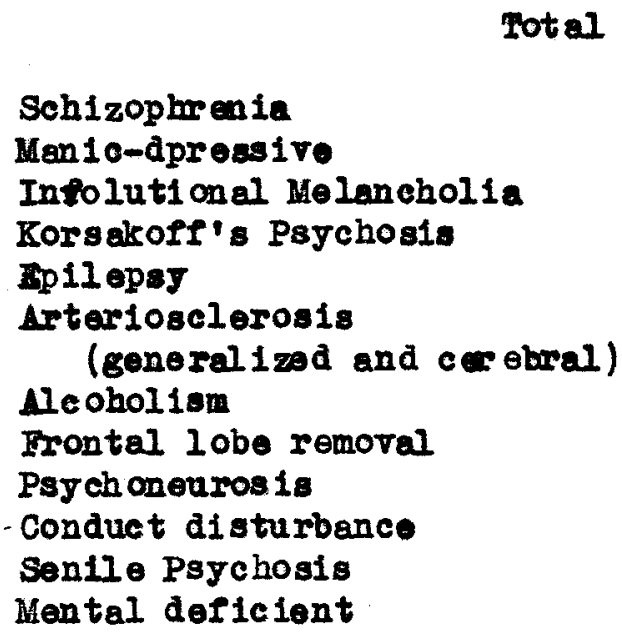 & $\begin{array}{l}21 \\
3 \\
2 \\
1 \\
1 \\
1 \\
2 \\
1 \\
1 \\
5 \\
1 \\
2 \\
1\end{array}$ & $\begin{array}{l}18 \\
3 \\
1 \\
1 \\
1 \\
1 \\
0 \\
1 \\
1 \\
5 \\
1 \\
2 \\
1\end{array}$ & $\begin{array}{l}3 \\
0 \\
1 \\
0 \\
0 \\
0 \\
2 \\
0 \\
0 \\
0 \\
0 \\
0 \\
0\end{array}$ \\
\hline
\end{tabular}


TABIF 9--Continued

\begin{tabular}{|c|c|c|c|c|c|}
\hline \multicolumn{3}{|c|}{ Prognosis } & \multicolumn{2}{|c|}{ Disposition } & \multirow[b]{2}{*}{ Other } \\
\hline Poor & Paif & Other & $\begin{array}{l}\text { Retumed } \\
\text { Home }\end{array}$ & $\begin{array}{l}\text { DI soh arged to } \\
\text {. Lake l and }\end{array}$ & \\
\hline 11 & 6 & 4 & 13 & 4 & 4 \\
\hline 8 & 1 & 0 & 3 & 0 & 0 \\
\hline 1 & 1 & 0 & 0 & 1 & 1 \\
\hline 0 & 0 & 1 & 1 & 0 & 0 \\
\hline 1 & 0 & 0 & 0 & 1 & 0 \\
\hline$\overline{1}$ & 0 & 0 & 0 & 1 & 0 \\
\hline 2 & 0 & 0 & 1 & 0 & 1 \\
\hline 0 & 0 & 1 & 1 & 0 & 0 \\
\hline 1 & 0 & 0 & 1 & 0 & 0 \\
\hline 1 & 3 & 1 & 3 & 0 & 8 \\
\hline 0 & 1 & 0 & 1 & 0 & 0 \\
\hline 2 & $\overline{0}$ & 0 & 1 & 1 & 0 \\
\hline 0 & 0 & 1 & $\bar{I}$ & $\overline{0}$ & 0 \\
\hline
\end{tabular}

in the proceas of study. Fifty-five patients had as their primary diagnosis one of the 26 diseases. Diseases of the ho art and circulatory aystem were first in numerical importance, affecting 18 out of 55 patients, or one-third. Heart disesse accounted for the largest number of hospital adnissions, throe times as many as any other disease as show in table 10. The duration of 1llness among card lac patients was longer then anong other conditicns with orer one-third of cerdiacs having had this condition between five and ten years. Two cardiac patients as shown in table 11 reported between ten and fifteon years duration of illness, one patient between fifteen and twenty jears, and one botween twenty and thirty the paychiatric. 
TABLE 10

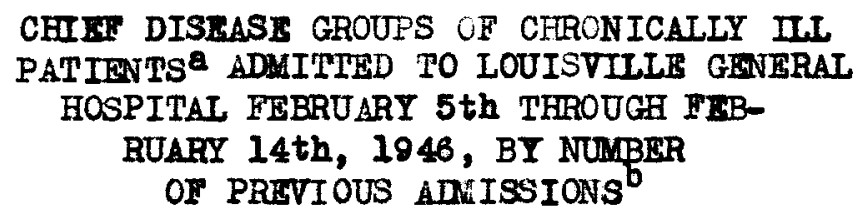

\begin{tabular}{|c|c|c|c|c|c|c|}
\hline Disease groups & Total & $\begin{array}{c}\text { Potal Adnission } \\
\text { Each disease }\end{array}$ & $\begin{array}{r}\mathrm{Nw} \\
\mathrm{r}\end{array}$ & $\begin{array}{l}\text { mbe } \\
\text { lou }\end{array}$ & 2 & $\begin{array}{l}\text { Pre- } \\
\text { dimias 1ons } \\
3 \text { or } \\
\text { over }\end{array}$ \\
\hline 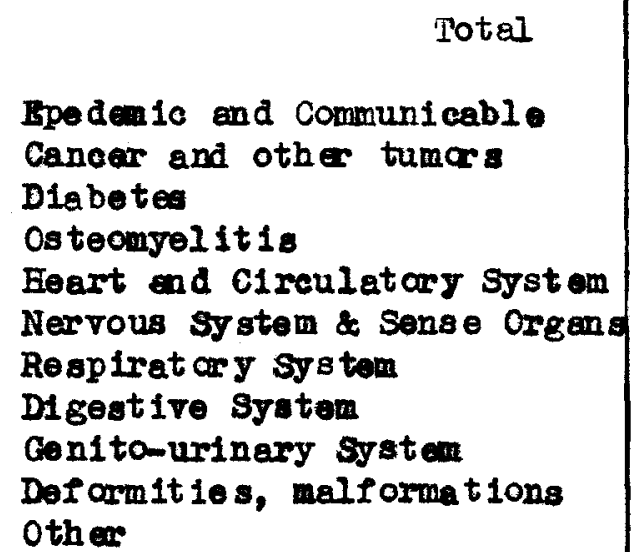 & $\begin{array}{r}55 \\
4 \\
5 \\
4 \\
4 \\
18 \\
6 \\
2 \\
3 \\
3 \\
4 \\
2\end{array}$ & $\begin{array}{r}70 \\
0 \\
13 \\
11 \\
11 \\
30 \\
5 \\
1 \\
3 \\
3 \\
2 \\
0\end{array}$ & $\begin{array}{l}28 \\
4 \\
1 \\
2 \\
0 \\
0 \\
4 \\
1 \\
1 \\
1 \\
3 \\
2\end{array}$ & $\begin{array}{l}12 \\
0 \\
2 \\
0 \\
1 \\
5 \\
1 \\
1 \\
1 \\
1 \\
0 \\
0\end{array}$ & $\begin{array}{l}0 \\
0 \\
0 \\
2 \\
0 \\
0 \\
0 \\
1 \\
1 \\
1 \\
0\end{array}$ & $\begin{array}{c}10 \\
0 \\
2 \\
2 \\
1 \\
1 \\
1 \\
0 \\
0 \\
0 \\
0 \\
0\end{array}$ \\
\hline
\end{tabular}

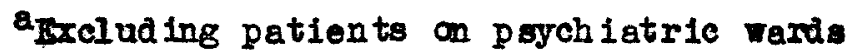

b For ame or allied diagnosis

Three patients each had elght previous admissions

years $\ldots$ Next in importance, but occurring only one-third es frequently as the heart and circulatory diseases were the diseases of the nerrous system and sense organs, incl uding epilepsy, tabes doralis, hemiplegia, loss of vision due to glaucona, and an illdefined neurological condition poss tbly caused by a spinal cord tumor.

Cancer was the third largest categary accounting for nine percent of all illness. Fidemd and communicable diseses, including pollomyelitis, pulmonary and non-pulmonary tuberculosis, and renereal disease, diabetes, os tecmyelitis, and deformit ies and malformations 
TABTE 11

CHIFE DISFASE GROUPS OF CHRONICALIY IIL PATIINTS ${ }^{\theta}$ ALUITTED TO LOUISVIIIS GRNERAL HOSPITAI FEBRUARY 5th THROOGH FEBRUARY 14th, 1946 BY DURATION OF IILNESS

\begin{tabular}{|c|c|c|c|c|}
\hline \multirow[b]{2}{*}{ Di sease Croupa } & \multirow[b]{2}{*}{ Total } & \multicolumn{3}{|c|}{ Duration of IIIness } \\
\hline & & $\begin{array}{l}\text { Under } 1 \\
\text { month }\end{array}$ & $\begin{array}{l}1 \text { Month } \\
\text { undex } \\
1 \text { year }\end{array}$ & $\begin{array}{l}1 \text { Jear } \\
\text { under } \\
5 \mathrm{Jr}\end{array}$ \\
\hline Total & 55 & 8 & 8 & 13 \\
\hline 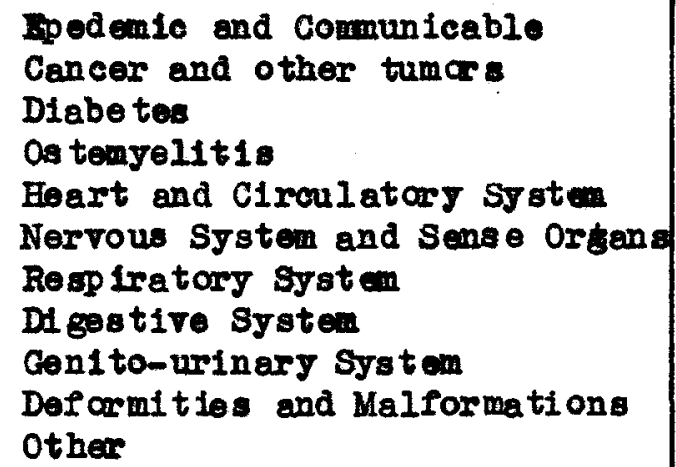 & $\begin{array}{r}4 \\
5 \\
4 \\
4 \\
18 \\
6 \\
2 \\
3 \\
3 \\
4 \\
2\end{array}$ & $\begin{array}{l}0 \\
0 \\
2 \\
0 \\
2 \\
2 \\
0 \\
0 \\
1 \\
0 \\
1\end{array}$ & $\begin{array}{l}0 \\
1 \\
0 \\
0 \\
3 \\
0 \\
0 \\
2 \\
1 \\
1 \\
0\end{array}$ & $\begin{array}{l}3 \\
2 \\
2 \\
0 \\
2 \\
3 \\
0 \\
1 \\
0 \\
0 \\
0\end{array}$ \\
\hline
\end{tabular}

arcluding patients on pychiatric rards 
EABT: 11-Continued

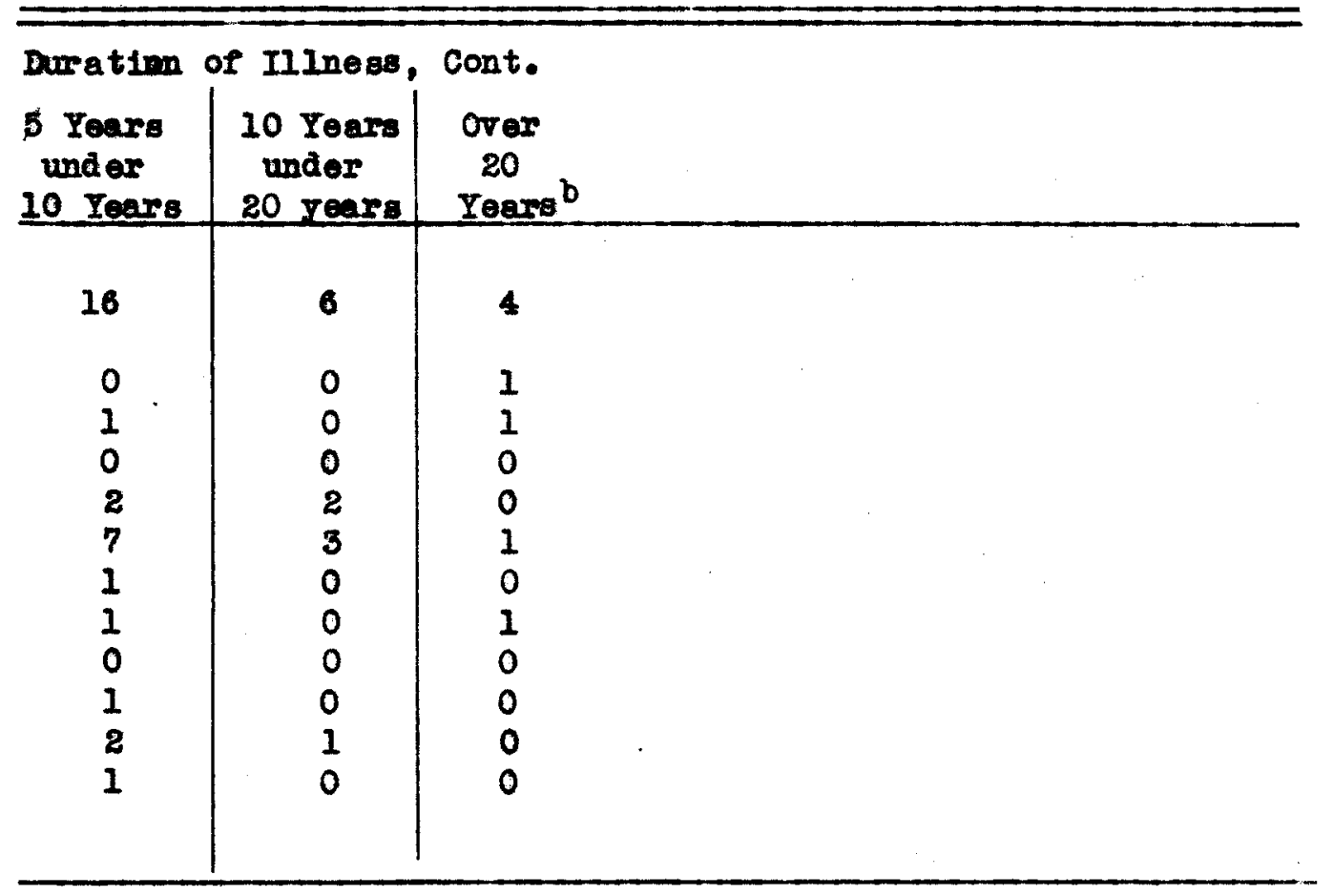

bone patient had been 111 for forty yeare.

were each responsible for seren percent of chronic 1liness. Six percent of chronic 11 inees wes due to digestive system and six percent to genitaurhary system disordera. Lsthma and chronic bronchitis, respiratory diseses accounted for four percent, chronic alcohollam and skin and cellular tisoue for one and one-half percent each. There rore no cases of arthrits and rhounatian in this atuig but the National Health Survey $s$ howed rhoumatism to be the most provalent disease, wi th heart disease rankin f first as a cause of death, and the nerrous and mental disesses causing the greatest di sabllity. 
The date in this study does not contain as complete a set of criterla for determining which di sease renks first in order of mortality and disability os might be desired, but it clearly shows that heart disease is the most prevelent. Five of the 55 patients died wh1le the study res in progress, three of cardiac conditions, one of cerebral accident, and one of cancer. In 1945 the leading causes of death in Loulspille and Jefferson county in order of importence were: diseases of the heart, cancer, cerebral hemorrhage, tuberculosis, chronic nephrit is, pneumonia, diseases of early infancy, arteriosclerosis, accident falls, and automobile accidents. It is important to note that of the first ten leading causes of death, six were chronic diseases. 1 The amount of disability caused by particular disease can be judged by rarious factors; duration of illness, condition (whether the patient is ambulatory, needs crutches or a cane in welking or is so disabled as to be confined indoors, uses a wheelchair, or is bodridden), and whether the individual is prevented from carrying on normel puraults. According to our definition, all chronic disease is of relatively long duration and interferes with one's occupation and normal physical and social life but there is a difference in the actual average duration of eech 11 iness and in the degree to which it interferes with narmal living. Patients with heart disease had the longest duration of 1llness, over one-third having been 111 for five to ten years. There were more bed ridien cardiacs then there were

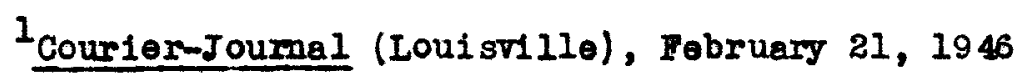


bedridden patients in $\mathrm{m}$ other disease grouping and this was also true of the partially ambulatory. Two thirds of all cardiacs were partially ambulatory and bedridden as shown in table 12. Among the nine individuals whose last gainful employment had been over five years before the present hospitalization, five were victims of heart and circulatory system diseases, two had diseases of the nervous system and sense organs, and two had cancer. It therefare appears thet heart disease caused more disability among the patients of this study, as measured by duration of illness, condition of patient, and interference with occupation than did any other disease. of the few known deaths, more were caused by cardiac conditions then by any other disease, and heart di sease was almost one half as prevalent as all others combined. In terms of prevalence, nortality, and disability, heart disease ranks first. Cancer ranks second as a calise of death, second as a cause of di sability, and third in prevalence. The nervous system diseases were second in prevalence, and shared second place with cancer to a cause of disability. The mortality rate for this group is not known but one can suspect that it is low.

Nearly one fourth of patients excluaing the psychiatric had two or nore chronic conditions simultaneously. The second condition might have been entirely unrelated to the first, but more usually it was a result or complication of the first condition, e.g. anemia resulting from the primary diagnosis, endometrial hyperplasia. The one causing the greatest disability or the more active, or the one that resulted in hosoltalization was 
TABLE 12

CHIBR DISFASE GROUPS OF GHRONICALTY

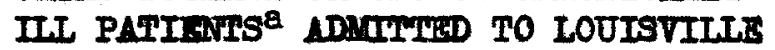

CEIERAI HOSPITNL FHBRUNRY 5th THROUCH

FBBRUARY 14th, 1946 BY CORDITION

\begin{tabular}{|c|c|c|c|}
\hline Disease Groups & Fotel & $\underset{\text { monom }}{\text { mom }}$ & $\begin{array}{l}\text { ition } \\
\text { Ambula- } \\
\text { tory }\end{array}$ \\
\hline 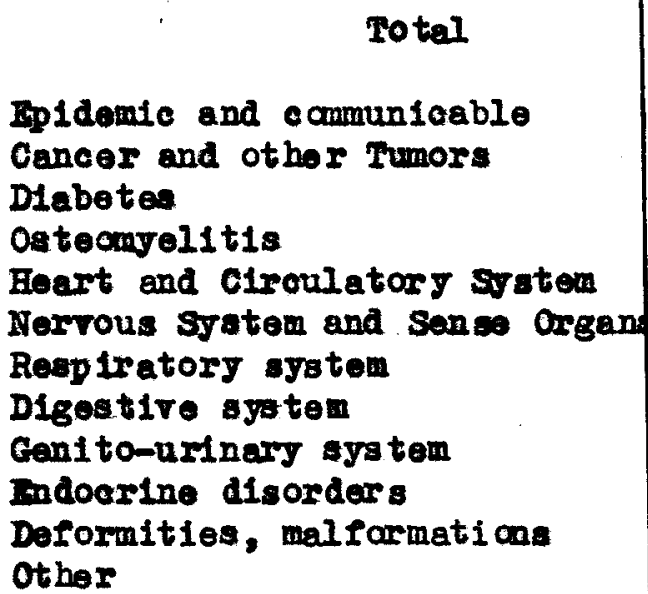 & \begin{tabular}{|r}
55 \\
4 \\
5 \\
4 \\
4 \\
18 \\
6 \\
2 \\
3 \\
3 \\
0 \\
4 \\
8
\end{tabular} & $\begin{array}{l}1 \\
0 \\
0 \\
0 \\
0 \\
1 \\
0 \\
0 \\
0 \\
0 \\
0 \\
0 \\
0\end{array}$ & $\begin{array}{l}28 \\
2 \\
2 \\
3 \\
2 \\
5 \\
4 \\
1 \\
3 \\
3 \\
0 \\
1 \\
2\end{array}$ \\
\hline
\end{tabular}

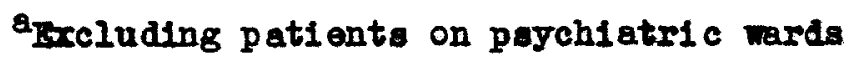




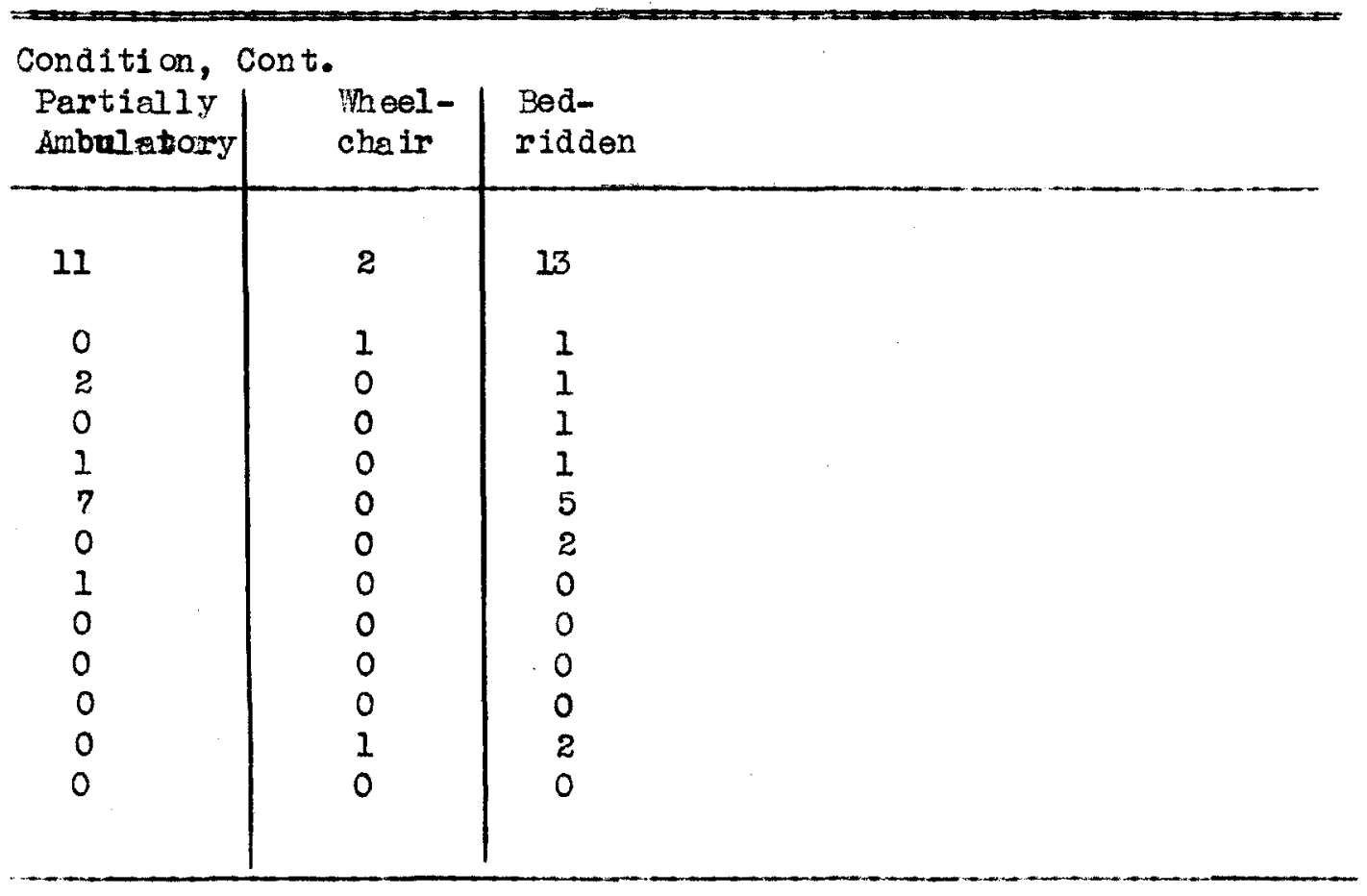

considered the primary diagnosis and the candition next in importance, the secondery diagnosis. Frequently the medical record contains what appears to be a secondary but is really intended to serve as additional explanation and clarification of the primary diagnosis, Q.g. chronic hepatitis--Iipoldosis of liver. Table 2 lists the secondary diagnosis but does not show their relationship to the primary diagnosis. Heart disease again heads the list of secondare diegnosis in terms of prevalence. CONDITION

A total of 28 patients, or one half excluding the nsychiatric 
as shown in table 12. The next largest group of patients, one fourth, were bedridden. One $f$ if th were partially ambulatory lusing cane, crutches or confined indoors), and a small number, about four percent were wheelcheir patients. As menti on ad above, more of the cardiac patients were bedridden and partially ambulatory than any other disease group. The cardiacs were one third of total patients, and two thirds of all cardiacs were partially ambulatory and bedridden. There were ambulatory patients in every disease grouping, partially ambulatory am ong the cancer, osteomyelitis, heart disease, and diseases of the respiratory system patients, wheelchair among the epidemic and communicable disease and deformity and nalformation patients, and bedridden anong the epidemic and communicable, cancer, diabetes, osteomyelitis, cardiac, nervous system, sense organ, and deformities and malf ormations patients.

\section{PROGNOSIS}

The prognosis was learned for the 30 patients exclusive of the psychiatric who were in the wards at the time of the study fron the doctor of each patient. The prognosis, or forecast of the course of the disease wes poor in almost half of the cases and very poor in five or one sixth. The prognosis was considered farr in only three cases and good in four. Combined, good and fair or favorable made up less than one fourth of total prognoses. The outlook for more than two thirds of patients was poor or very poor; unfavorable. Doctors would not venture an opinion on the prognosis of four patients. In several instances of very poor prognoses the doctors added rultinate death". It would appear, if these prognoses were correct, that there is little that can be accomplished in the way of rehabilitation for these patients. However, many factors play a part in deciding whether the 
patient will get well; including the patient's emotional adjus tment, whether he continues treetment upon leering the hospital, the kind of hame he returns to, and whether he is recelring the kind of care that his condition calls for. The conlition of the hemiplegla patient is often the most pitiful of all in the hospital. Heniplegia, usually the result of cerebral hemorrhage, embolism, or thrombos 1s, consists of paralysis of one side of the body and is usually accompanied by 10ss or speech and incontinence of bledder and bowel morement. ine patient's mind is alert, but unable to give volce to his thoughts, he nevertheless attempts to do so by emitting unnatural gutteral sounds. He is usually placed in a separate room off the ward raserved for the serlously ill and his bed is surrounded by boards to prevent him from felling out. 1 very poor prognosis may be pronounced and yot some of these patients leare the hospltal with speech and almost full motica restored. One such pationt, visited after his discharge fron the hospital, was found seated in the warm sun on the porch of his home, happily relating the miracle that had been wrought, When discharged he had been regaining the use of his extremities and he continued to feel improvement every day. It would be a long time however, if ever, before the patient could hope to return to his former employment as a laborer for a railroad. This patient 's improvement wald be reatly enhanced by the services of a skilled nurse or physiptherapist to administer massege to aid in mucular coordination, trengthening of the weak wocles and stretching of the stronger spastic ones.l Table 13 shons prognosis by various disease groups.

IErickson, Don J. And Krusen, Mrank J., "Physical Therapy Comes to the Ald of the Aged," The Modern EOspital. Vol.62. N0.5. ley, 1944, p. 90 . 
OHISF DISTASE GROUPS OF CHRONICALLY

III PATIENTSA ADMTTPED TO LOUISVIILI

GENERAL HOSPITAL FEEROLRY 5th FHROGH

FRBRUARY 14th, 1946, BY PROCMIOSIS OF PATIRANS

ON TARD AT TTME OF STUDY

\begin{tabular}{|c|c|c|c|}
\hline Dsease croups & rotal & $\begin{array}{l}\text { Un- Pro } \\
\text { knom }\end{array}$ & $\begin{array}{l}\text { ogis } \\
\text { pory } \\
\text { poor }\end{array}$ \\
\hline Total & 30 & 4 & 5 \\
\hline $\begin{array}{l}\text { Fidemic and communicable } \\
\text { Cancer and other lumors } \\
\text { Dabetes } \\
\text { Oateomyelitis } \\
\text { Heart and Cirevlatory system } \\
\text { Nerbous System and Sense orga } \\
\text { Respiratory sys tem } \\
\text { Digestive system } \\
\text { Genito-urinary aystem } \\
\text { Deformities, malformations }\end{array}$ & $\begin{array}{l}2 \\
2 \\
2 \\
3 \\
7 \\
n s \\
5 \\
1 \\
3 \\
0 \\
3\end{array}$ & $\begin{array}{l}0 \\
0 \\
0 \\
1 \\
0 \\
1 \\
0 \\
1 \\
0 \\
1\end{array}$ & $\begin{array}{l}0 \\
1 \\
0 \\
0 \\
3 \\
1 \\
0 \\
0 \\
0 \\
0\end{array}$ \\
\hline
\end{tabular}

apreluding patienta on psyehiatric wards 


\begin{tabular}{l|l|l}
\hline \multicolumn{2}{l}{ Prognosis, cont. } \\
Poor & rair & Good \\
& & \\
\hline & & \\
14 & 3 & 4 \\
2 & 0 & 0 \\
3 & 0 & 0 \\
0 & 0 & 2 \\
1 & 0 & 1 \\
4 & 0 & 0 \\
3 & 0 & 0 \\
1 & 0 & 0 \\
0 & 2 & 0 \\
0 & 0 & 0 \\
0 & 1 & 1 \\
& & \\
\hline
\end{tabular}

In the New York City study of chronlc patients in 1928 the outlook for recovery was farorable far only one tenth of the adul ts under sixty years of age, and for $25 \%$ of the chlldren which is a much lower percentage. of favorable prognoses than in the present study, but $70 \%$ of adult patients were ambulant, in comparis on $w$ th $50 \%$ of chronic patients at General Hospital in Louistille.

\section{DURATION OF IITNESS}

Duration of the illness was counted eran the time that the patient Iirst beome arare of the difficulty or when the diagnosis was confirmed by a physician. In not all cases was this Identical, as a condition may have existed but gone undisnosed and untreated for a perlod of years. However, the patient's clinical history would usually shor 
that the prosent and pest eomplaints were ralated to the same condition and the date whon the patient first felt the symptams of the disease (not the aeute symptans of the present attack) would be a reas onable measure of the onset of the 1liness. Phis method is not accurate in all situations, for example, among some of the gynecological diseases such as salpingitis, flbrold uterus, and cancer of the eervix, the patient is often unaware that the condition exists until a large mess is felt in the pelvis. One gmecology patient reported the onset of the condition (cmronle pelvic inflammatory diserse) to be two weaks prior to coning to the hospital, but the medical record showed an admission in 1939 for gonorrheal vaginitis. Theae complaints were definitely related, and the duration of the 11lness was therefore tabulated as seven years. Similarly, the other gynecology cases were reported to be of briof duration ranging from serer days for one, to under one year for another. Squamous cell oarcinome of the cervix had been diagnosed seren months previously but by this time it had metastasized. Whon the disease has progressed insidiously the date of onset is often difficult to determine. The median arerege duration of illness was four and one half years. In Nen York City the arerage period of disability was 5.8years. Amost one third of total patients excluding the psychiatric had been 111 between fire to ten years as a result or chonic illness. Table 11 shows the distribution with the next largest group of patients reporting the duration of their illness to be between one and two years. The duration of 11 lness ranged from less than one week to 40 years, with one patient at each extreme, the former having diabetes and the latter cancer. The diagnos 1s of diabetes was not made until the 
patient had attended bench clinic complaining of grnocological and eyo disorders and had been given a thorough work up. The patient was unaware of the condition until this time, and the approximate onset of the disease was fixed at under one woek, when in all probebility it was much before this. Meren of the 16 heart and circulatory system patients with kmown duration of illness were 111 betreen five to 20 yeara, ceren of these between fire to ten years. The diseases which eppeared to have the shortest duration, exclusive of diabetes and gynecological, were those of skin and cellular tissue, digestive system, and the epidemic and communicable. As the median average does not take the extreme figure into account, cancer also had a short duration of lllness, averaging only elght months. Diseases of long duration were chronic alcholism, osteomyelitis, deformitios and malformations, and cardiac conditions. HOSPIFaL AmISSIONS

The total days of hospital care and the total number of hospitel admissions at Louisville Coneral Hospital, per patient, not including the psychlatric, were calculated for all admissions for the same or alliod diagnosis, excluding the present. This is a revealing item because it gives some indication of the extent to which Ceneral Hospital is belng used as a center for chronic care for the city's indigent population. Only elght patienta of the entire 55 had erer been admitted to eny other hospital in the eity, and one to an instifution for ohronie care (Central State Ho sital for mental disease). Total adisistons to all other hospitals for the same or allied diagnos is were eleren, as shown in table 14, in comparison with a total of 79 admissions (not including the present) to Loulsville General Hospital. 


\section{TUBLE 14}

PREVIOUS ADMISSIONS TO OTHER HOSPITALS, NURS ING HOWES, AND INSTITUTIONS OF CFRONICALLY

III PLTIENTS" ADMTTITED TO LOUISVILLE GEHERAI

HOSPITAL FBBRUARY 5 th THROJGH FEBRUARY $14 \mathrm{th}, 1946$

\begin{tabular}{|c|c|}
\hline Prev1ous Admissions & Number \\
\hline $\begin{array}{l}\text { Hospitals } \\
\text { Hone } \\
\text { Red Cross } \\
\text { St. Joseph } \\
\text { st. Inthony } \\
\text { St. Nary and Hizabeth } \\
\text { Irny } \\
\text { Kosair } \\
\text { Deaooness } \\
\text { Childrens Free } \\
\text { Nursing Homes } \\
\text { None } \\
\text { Ins titutions } \\
\text { None } \\
\text { Ormsby Village } \\
\text { Lakeland }\end{array}$ & $\begin{array}{r}47 \\
3 \\
2 \\
1 \\
1 \\
1 \\
1 \\
1 \\
1 \\
55 \\
53 \\
1 \\
1\end{array}$ \\
\hline
\end{tabular}

aincluding patients on psychiatric wards

Howerer, as 28 patients had not had any previous adnission to

Ceneral Hoopitel, the median average of total previous admission per patient is only .8. The median average admission for only those patients who had had previous admiss ions 18 2.3 , and including the present admission, 3.3. Three pationte who had been discharged were readmitted during the course of the study. Cardiec patients accounted for 30 of the 79 previous admissions, cancer patients for about half of this number, and respiratory for only one previous admission. There rere no previous admissions for diseases of skin 
and cellular tissue. Previous edmissions for the secondary and other diagnoses were not recorded but add up to a sizeable number. Table 10 shows the previous admissions for each disease group.

The total number of hospital deys per petient, previous admissions, ranged from none to 204 days, 8.8 shown in table 15 , with the modian average days per patient, 5.8 days, not including the psychiatric.

\section{TABIR 15}

NUMBER OF PFEVIOUS ADMISSIONS

OF CHRONICAILY IIL PATIENISb AIMITTED TO LOUISVILIF

GHNERAL HOSPITAI FEBRDARY 5th THROUGr FEBRDARY 14th, 1946 BY TOTAL HOSPITAL DAYS PER PATIIENTC

\begin{tabular}{|c|c|c|c|c|c|}
\hline \multicolumn{2}{|c|}{$\begin{array}{l}\text { Namber of Preri ous } \\
\text { Admise1 ons } \\
\text { | Total }\end{array}$} & $\begin{array}{l}\text { Total } \\
\text { Under } 10\end{array}$ & $\begin{array}{c}\text { Tospital Da } \\
10 \text { Under } \\
50\end{array}$ & $\begin{array}{l}\text { Per Pats } \\
30 \text { Under } \\
90\end{array}$ & $\begin{array}{l}\text { nt } \\
\text { orer } 90 \text { d }\end{array}$ \\
\hline Total & 55 & 35 & 9 & 8 & 3 \\
\hline $\begin{array}{l}\text { None } \\
1 \\
2 \\
3 \text { or orer }\end{array}$ & $\begin{array}{r}28 \\
12 \\
5 \\
10\end{array}$ & $\begin{array}{r}28 \\
7 \\
0 \\
0\end{array}$ & $\begin{array}{l}0 \\
5 \\
2 \\
2\end{array}$ & $\begin{array}{l}0 \\
0 \\
3 \\
5\end{array}$ & $\begin{array}{l}0 \\
0 \\
0 \\
3\end{array}$ \\
\hline
\end{tabular}

aror some ox allied diagnosis

breluding patients on psychiatrie rards

CFelud ing present hopitalization

dwo patients each had over 200 hospital days

It was not possible to include the average days of the present hospitalization as more than one half the patients were still in the hospital at the time of the study. An estimate or the total day per pationt ineluding the present hospitalization oan be arrived 
at by taking the known median for previous admis 1 ons, 5.8, and adding to it the average number of days stay per patient including both acute and chronically 11l, 12 deys. This gives a total of about 18 days per patient, a figure wich would be even higher if the average days of previous admissions had been calculated for only those patients who had had previous admissions and had not included the 28 patients with no previous admissions. (on this basis the median patient days of previous admissions would be 20.2 doys plus 12 days).

COST OF CAET

To learn the cost of 18 drys care per patient, total hospital patient days $f$ or the year 1945 may be dividod into total hospital expenditures for ward patients for the same year, and the per diem cost thus arrived at, multiplied by 18. The hospitel is 1945 soent a total of $\$ 894,227.11$ in actual money received from city and county funds. No estimate ras made of the contributions from University of Louisville Medical School in services and salaries paid the medic al staff. The sedic 1 school pald part of the salaries of the interms and residents, and the entire salary of those of its faculty who are on the staff in the General ospital. Of the total money received from the city and county, it is estimated that about one fourth is used by the out-patient department, which leaves a balance of three fourths or $\$ 670,670.34$ for ward patients. There were a total of 101,720 clinic visits and 26,047 emergency room vi sits or 127,767 total out-petient department visits in 1945 , and 143,256 hospital days for ward patients. 143,856 divided into \$670,670.34 gives the per diem cost, 4.68 . The average cost to the city of caring for each chronically ill patient in this study, not including the 
poychiatric (per diem cost multiplied by 18 days per patient) was \$84.24. This a minimum cost, howerer, as it does not take into account the Medical school contribution, interest on investment, dopreciation of property, buildings, and equipment. The actual cost is therefore much higher. The total $5 b$ patients cost the city an average of \$483.20. The cast for one patient alone, a diabetic who in flre admissions spent 204 days in the hospital, was $\$ 954.72$ exclusive of clinic cost. By actual number of hospital days, 1,152, the total cost was $\$ 5391.36$. In the following chepter we shall consider what the estimated cost would be if these patients were accomodated in a chronic disease hospital. PATIENTS CONRRIBUTION TONARDS THE COST OF CARE

The above figures are based on the assumption that none of these patients were paying anything towards the cost of their care. The greatest number, 51, excluding the psychiatric, were receiving free care, one was paying part, and two were paying almost full cost. The pay status of one patient was unknom. The Kentucky Crippled Childreas Commisaion paid for the two full pay patients. The one part pay patient had an income of 148 fram his wife's earnings. None of the patients had hospitalization insurance.

All hospital patients, out-patient, and in-patient, are given a hospital elassification by the admissions department, based on thelr ability to pay. The classificationcs are "A", \$4 a day plus costs, "B", \$4 a day with no extra charge for x-rays, test, operating room and other expenses, and " ${ }^{n}$, free. A similar scele exists for clinic patients and sane patients are given one classification for clinic, a nother for ward. In the main, a patient with an income of $\$ 1500$ and no de- 
pendents is given an "A" classification. Insurance cases, those under the Bmergency Maternal and Infant care program, and those alded by agencies such as American Red Cross and Kentucky Crippled Childrens Commission are classified as "A" patients.

PABLE 16

HONTELY INCONE OF CHRONICAILY ILL PATIENTS ADWITTED TO LOUISVILLE GBNTRAL HOSPITAL FMBRUARY 5th THROUGH FHBRUARY 14th, 1846 BY WARD AND HOSPITAL CLASSIFICATION, $A, B, 0$ O

\begin{tabular}{|c|c|c|c|c|c|c|}
\hline Monthly & Incone & tal & Medical & $\begin{array}{l}\text { Fard } \\
\text { Surgi cal }\end{array}$ & Baby & Payohiatric \\
\hline $\begin{array}{l}\text { Unknown } \\
0-19.99 \\
20-39.99 \\
40-59.99 \\
60079.99 \\
80-99.99 \\
100-119.99 \\
120-139.99 \\
140-159.99 \\
160 \text { and over }\end{array}$ & Potal & $\begin{array}{r}76 \\
33 \\
12 \\
3 \\
4 \\
5 \\
6 \\
4 \\
4 \\
8 \\
3\end{array}$ & $\begin{array}{r}36 \\
15 \\
8 \\
2 \\
1 \\
3 \\
3 \\
1 \\
2 \\
1 \\
0\end{array}$ & $\begin{array}{r}17 \\
7 \\
4 \\
1 \\
2 \\
1 \\
2 \\
0 \\
0 \\
0 \\
0\end{array}$ & $\begin{array}{l}2 \\
1 \\
0 \\
0 \\
0 \\
0 \\
0 \\
1 \\
0 \\
0 \\
0\end{array}$ & $\begin{array}{r}21 \\
10 \\
0 \\
0 \\
1 \\
1 \\
1 \\
2 \\
2 \\
1 \\
3\end{array}$ \\
\hline
\end{tabular}

$a_{1}=$ rull pay patient; $\$ 4$ per das plus costs

$B$ - part pay patient; \$4 per day

0 eree patient 
TABIS 16-Gontinued

Hospital Classification

\begin{tabular}{l|l|l|l} 
Inknown & $\mathbf{1}$ & $\mathbf{B}$ & $\mathbf{C}$ \\
\hline & & \\
\hline & 2 & 2 & 61 \\
0 & 2 & 0 & 27 \\
0 & 1 & 0 & 11 \\
0 & 1 & 0 & 3 \\
0 & 1 & 0 & 3 \\
0 & 0 & 0 & 4 \\
0 & 0 & 0 & 4 \\
0 & 1 & 1 & 2 \\
0 & 1 & 1 & 0 \\
0 & 2 & 0 & 1 \\
\hline
\end{tabular}

Table 16 shows the ho epital classification of all 76 petients, ineluing the psychiatric, by amount of income and by ward to shor the elaseifieation of petients in the paratatric vards. There is no correl ation between the ward and hospital classification except in the case of the psychiatric patients. It is interesting that seren of the psychiatrie patients, ar one third, were "A" or full pay patients, while only two of the 55 pationts had "A" clessifications. one psychiatric patient had a "B" clessification, ten were "C", and 
classifications of three patients were unknom.

\section{TABLE 17}

SOURCE OF INCOME OF CHRONICALLY IIL PATIENTS

ADMTTITE TO LOUISVIILE GENERAL HOSPTIAL

FEBRUAFY 5 th THROUGH FEBRUARY 14th, 1946

BY AMOUNT (MONTELY)

\begin{tabular}{|c|c|c|c|c|}
\hline Souree of Incone & Total & $\begin{array}{l}\text { Amount } \\
\text { Onknown }\end{array}$ & $\begin{array}{l}\text { of Incone } \\
\text { Unter } 10\end{array}$ & $\begin{array}{l}10 \text { under } \\
29.99\end{array}$ \\
\hline $\begin{array}{l}\text { Total } \\
\text { Rarninge } \\
\text { Savinga } \\
\text { Insurance } \\
\text { Irmy-iavya } \\
\text { Soc1al agenegb } \\
\text { Pensi on } \\
\text { Relative } \\
\text { Inat1tution } \\
\text { Other, unknown }\end{array}$ & $\begin{array}{r}76 \\
28 \\
3 \\
2 \\
4 \\
14 \\
2 \\
12 \\
4 \\
7\end{array}$ & $\begin{array}{l}33 \\
9 \\
2 \\
2 \\
0 \\
5 \\
0 \\
9 \\
0 \\
6\end{array}$ & $\begin{array}{l}4 \\
0 \\
0 \\
0 \\
0 \\
0 \\
0 \\
0 \\
4 \\
0\end{array}$ & $\begin{array}{l}0 \\
0 \\
0 \\
0 \\
0 \\
9 \\
0 \\
0 \\
0 \\
0\end{array}$ \\
\hline
\end{tabular}

apay, allotment, pension 
TABIE 17--Gontinued

\begin{tabular}{c|c|c}
\hline \multicolumn{1}{|c|}{ Ant. of Inc., Cont. } \\
30 under & $\begin{array}{c}60 \text { under } \\
119.99\end{array}$ & $\begin{array}{c}120 \text { and } \\
\text { over }\end{array}$ \\
\hline 59.99 & & \\
\hline 6 & 15 & 9 \\
1 & 10 & 8 \\
1 & 0 & 0 \\
0 & 0 & 0 \\
3 & 1 & 0 \\
0 & 0 & 0 \\
1 & 1 & 0 \\
0 & 2 & 1 \\
0 & 0 & 0 \\
0 & 1 & 0 \\
\hline
\end{tabular}

bold ase assistance, Muncipal Bureau of Sccial Service,County Felfare Department, Other agencies Fere active, but not as a souree of income.

INCOME

The income of the poychlatric petients was considerably higher then the average income for all patients. The average income of the paychlatric patients (of el even known incomes) was \$l25. For all patients 1t was $\$ 64.50$. The eamings of on psychiatric patient, a chemist, were reported to be $\$ 500$ a month. The distribution is shown in table 17. There appears to be one point in the array at which a good many of the cases are ccneentrated; the income from 
$\$ 0$ to $\$ 20$. All of the $\$ 10$ to $\$ 30$ incomes were derived from a scelal ageney, seven from OId Age Assistance and two from lunicipal Bureau of Social Service. Half of the elght Old lge Assistance rocipients had an aditional source of incone, but the other halt lived entirely on the grant. There were five Municipal Bureau of Social Service clients in all and the anount recelved were unknown in three cases. Four of the five Munictpal Bureau of Social Service cltents lired entirely on the agency's assistance, and one was being helped by a relatire in addition. The County Wel fare department was active with one patient, amant of assistence unknown.

The average ineone of $\$ 4,50$ considers only the pritary soupce of the patients income, but 19 patient (including the psychiatric) had an aditional source to supplement the primary source. No attent was made to tabulate these, since the anounts were so raried in each case. Earnings, when the patient or a member of his family was employed, were elways considered as a primary source, and in fire cases carninga were supplemented by insurance, a pension, or relatives. All of the incomes exceeding $\$ 129$ were derived from earnings. Sarings constituted the major portion of the income in only three cases, but insurance supplemented sarlngs in only one case, and the other two patients Fere living entirely upon their savings. Insurance as a major part of the income occurred in only two casff as the emount of the claim was usually too small to meet all expenses and the number of benefit weaks was limited. Insurance did, however, form a supplementary part of the income in $s i x$ cases. The amount of insurance may in same cases exceed the public assistance grant, but It Is giren for a limited period while the latter may go on indefi- 
nitely. Pay, allotments, and pensions, are included in the eategory "army-navy" and were a major portion of income in four cuses and an addition to other income in one case. There were no petients receiving work or unemployment compensation. Social agencies supplied the major portion of the income in 14 cases, or half as many as lived on earnings. Distribution by agencies is stated above. Pensions vere a secondary source of income for three persons. Relatives helped almost as many patients as did social agencies. They were a primary source of income in 12 cases and the secondary source of income for six patients. Four patients lived in institutions, three at the Kings Daughters Home for Incurables, and one at the Home for the Aged and Infirm. There were seven patients $r$ eceiving incomes from sources not men tioned above. Two patients were receiving supplementel income from friends and from rent. This distribution is shown in table 18. Fable 17 shows the primary sources of income by anounts of incone. Table 18 al so shors the primary sources, whether they form the total income or are supplemented, what the supplementary sources of income are, and which primary source they are an addition to.

OCCLT:TION

The last knomn occupation of the 55 patients(excluding the psychiatric), as show in table 19, was cormiled by chief oc cupation groups and included own housework, school or institution, craftsmen and foremen, operatives end kindred, service workers, domestic workers, unskilled laborers and farmers. The re were no patients employed in tho professional or semi-pfofessional, proprietars, manufacturers, and oficials, or clerical and sales groups. The occupation of one patient was unknown, and five patients had no occupation. Unskilled laborers formed one fifth of the total occupations, with oneratives 
PRDMAFY SOURCE OP INCOME OF CHRONICAILY IIL PATIENTS AIMTTIED TO LOUISVILLE GENERAL HOSP ITAL FHBRUARY 5th THROUCH FEBRUARY 14th, 1946, BY ADDITIONAI SOURCE OF INCOME

\begin{tabular}{|c|c|c|c|c|}
\hline $\begin{array}{l}\text { Primary source of } \\
\text { Incoms }\end{array}$ & Total & $\begin{array}{l}\text { Addit } \\
\text { None }\end{array}$ & nal source & $\begin{array}{l}\text { of Income } \\
\text { Insurance }\end{array}$ \\
\hline $\begin{array}{l}\text { Harmings } \\
\text { Serings } \\
\text { Insurance } \\
\text { Arny-Navy } \\
\text { Social agencyb } \\
\text { Pens Ion } \\
\text { Relative } \\
\text { Institution } \\
\text { Other, Unknown }\end{array}$ & $\begin{array}{r}76 \\
28 \\
3 \\
2 \\
4 \\
14 \\
2 \\
12 \\
4 \\
7\end{array}$ & $\begin{array}{r}57 \\
23 \\
2 \\
1 \\
3 \\
9 \\
0 \\
9 \\
4 \\
6\end{array}$ & $\begin{array}{l}1 \\
0 \\
0 \\
0 \\
0 \\
0 \\
0 \\
1 \\
0 \\
0\end{array}$ & $\begin{array}{l}6 \\
1 \\
1 \\
0 \\
0 \\
1 \\
0 \\
2 \\
0 \\
1\end{array}$ \\
\hline
\end{tabular}

apay, allotment, pension 
HBIF 18-Con tinued

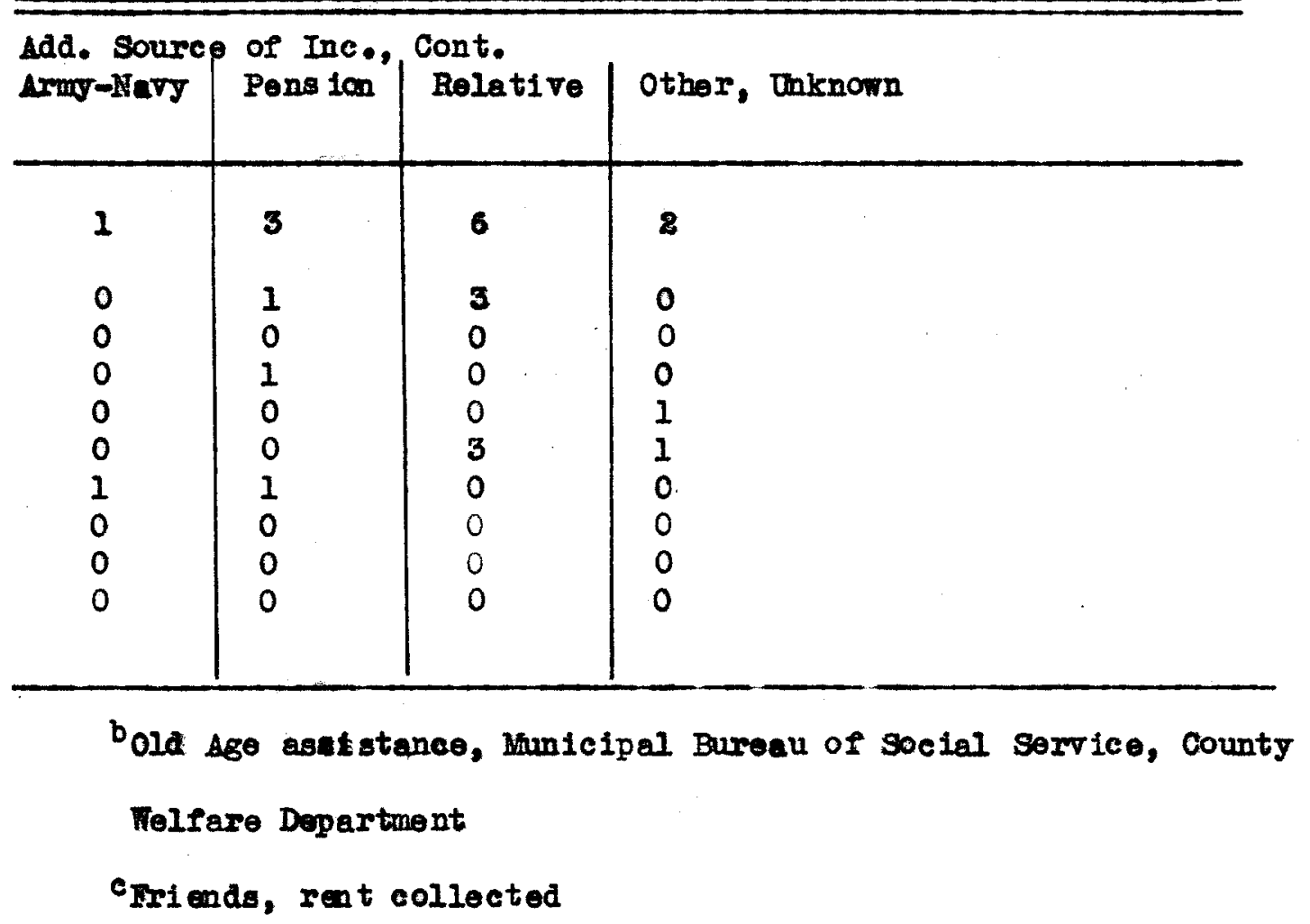


LAST KNOWN OCCUPATION OF CHRONICALLY IIL PATIENTS FHBRUARY 5th THROUGH FBBRUARY 14th, 1946 BY TIME OF IAST EMPLOYMERTI

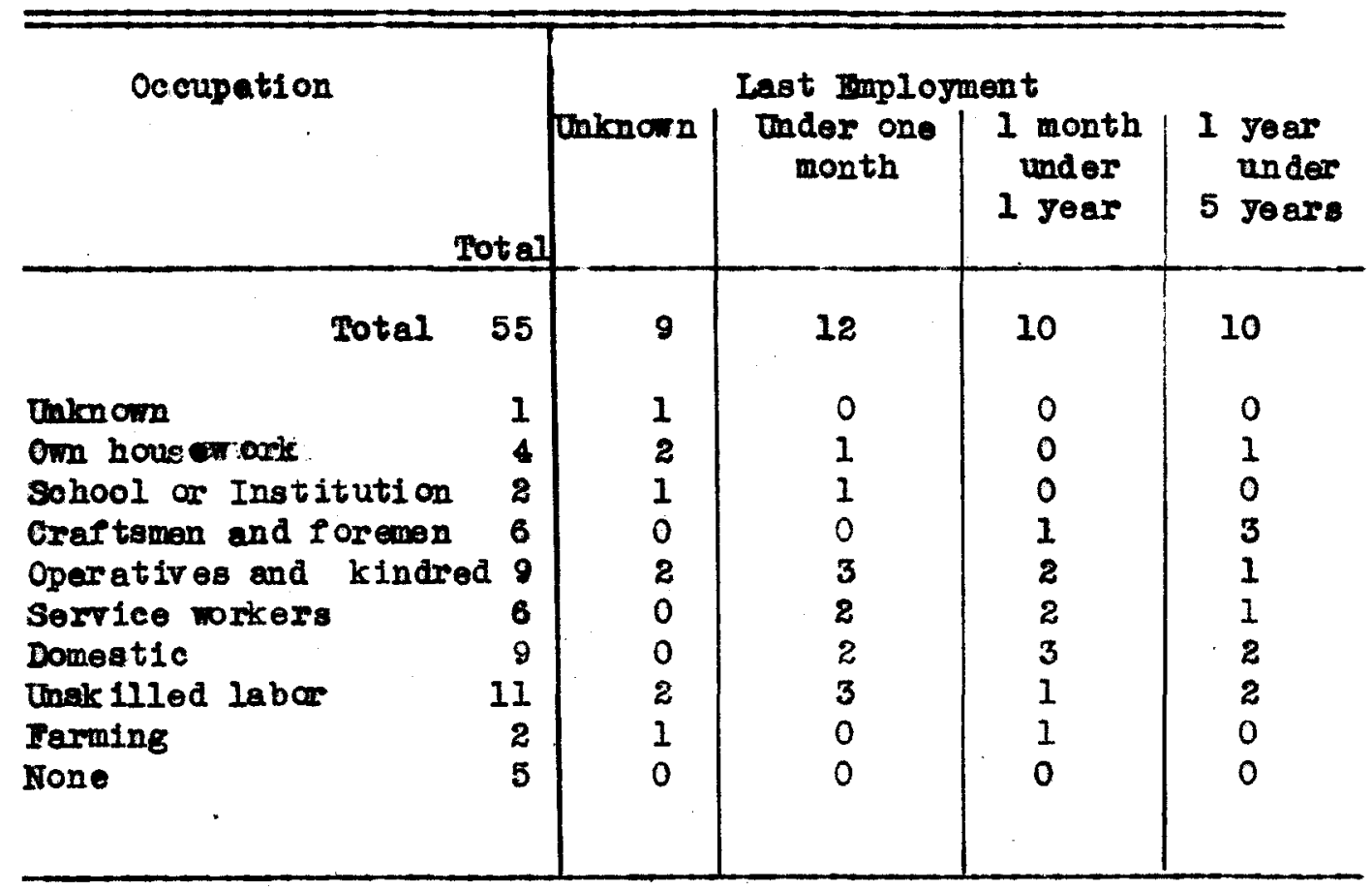

areluding patients on psychiatric wards. 
TABLE 19-Continued

\begin{tabular}{l|l|l} 
Last $\begin{array}{l}\text { Imployment, Cont. } \\
5 \text { jears } \\
\text { under } \\
10 \text { years }\end{array}$ & $\begin{array}{c}\text { orer } 10 \\
\text { jears }\end{array}$ & Never \\
\hline 5 & 4 & 5 \\
0 & 0 & 0 \\
0 & 0 & 0 \\
0 & 0 & 0 \\
2 & 0 & 0 \\
1 & 0 & 0 \\
0 & 1 & 0 \\
1 & 1 & 0 \\
1 & 2 & 0 \\
0 & 0 & 0 \\
0 & 0 & 5 \\
\hline
\end{tabular}


and kindred and domestic wakers follar ing close behind. There were more than twice as many domostic workers as there vere vomen doing housework in caly thelr own homes. There were the same number of craftemen and faremen as there were service workers. The amallest groups were camposed of farmers and those employed in schools and institutions (students and teachers).

Orer one fifth were at their jobs almost until they were admitted to the hospital (one month or less). One ninth rere last employed one and two years prior to this admission, and one sixth had not worked for flve years or longer before the present admission. In most cases this was directly attributable to the illness.

In stating their discharge plans, of patients in the wards at the $t$ ime of study, nine patients or almost one third said that they wanted to return to work. The last thine of employment for one of those patients was unkown, five had been employed fust before adission, but the remainding three had not been employed for a long time before. The prognos is for two of these three patients was poor, and for the third, good. The long time away from the job, coupled with the poor prognosis, makes it appear vers doubtful thet two patients in this group would return to work. In the group of five patients employed before admis sion, two had unfarorable prognoses. Therefore, out of aine petients who plenned to return to work upon discharge, about half would probebly not do so. This estimate of $50 \%$ ahould be regarded as being very liberal if the patients who had gone home and had a chence to work out their plans were any indication of what the patients still in the wards would be doing after their discharge..for only three of the total 25 discharged patients were known to heve returned to employment, or 
about one eighth.

HOUS ING

Bout four fifths of the patients, not including the psychiatrie, were living with relatives. Patients haring no homes formed a considerably smaller proportion than in the 1937 one der survey of General Hospital pationts. In that ourvey slightly orer 50\% of chronic and ineurable patienta had no homes. A hane, it will be recalled, was defined as "that residence either maintained by an indiridual, wfe, or husband, or own child". Using the same criterion, only one seventh or patients in the present study vere homeless, of more concem is the petient living alone, for although he has a home of his own in some cases bo may be receiting much poorer care than the institutional patient or the patient living with friends or boarding who has someone to look after him. As shom in table 8., a small number of patients were living alone, five of the total number.

The median number of people per household was 2.8 and the modien number of rooms, 2.4. Since in tabulating the number of rooms, the kitchen is usuelly included as a room, this woant thet 2.8 people were sleeping in one room. There were only .66 children Iiving in each household, As shown in table 8, about half of the patients hed a rocm to themselves and two thirds sleep al one.

of the totel 76 patients including the psychdatrie, 14 or one fifth were known to orn or be buying the1r home, 38 or exactly half were renting, four lired in institutions, and the housing of one fourth was unknown. The modian rent paid per month was 11.45 or orer one sixth of the median income, $\$ 4.50$. Table 20 shows rent 
TABLE 20

MONTHLY INCOMB OF CHRONICALLY IIL PATIENTS ADMITTED TO

LOUISVILLE GRNERAL HOSPITAL FRBRUARY 5 th THROUGH FEBRUARY 14th, 1946, BY MONTHLY RIHNT, OWN HOME ${ }^{2}$, OR IIVING IN INSTITUTION

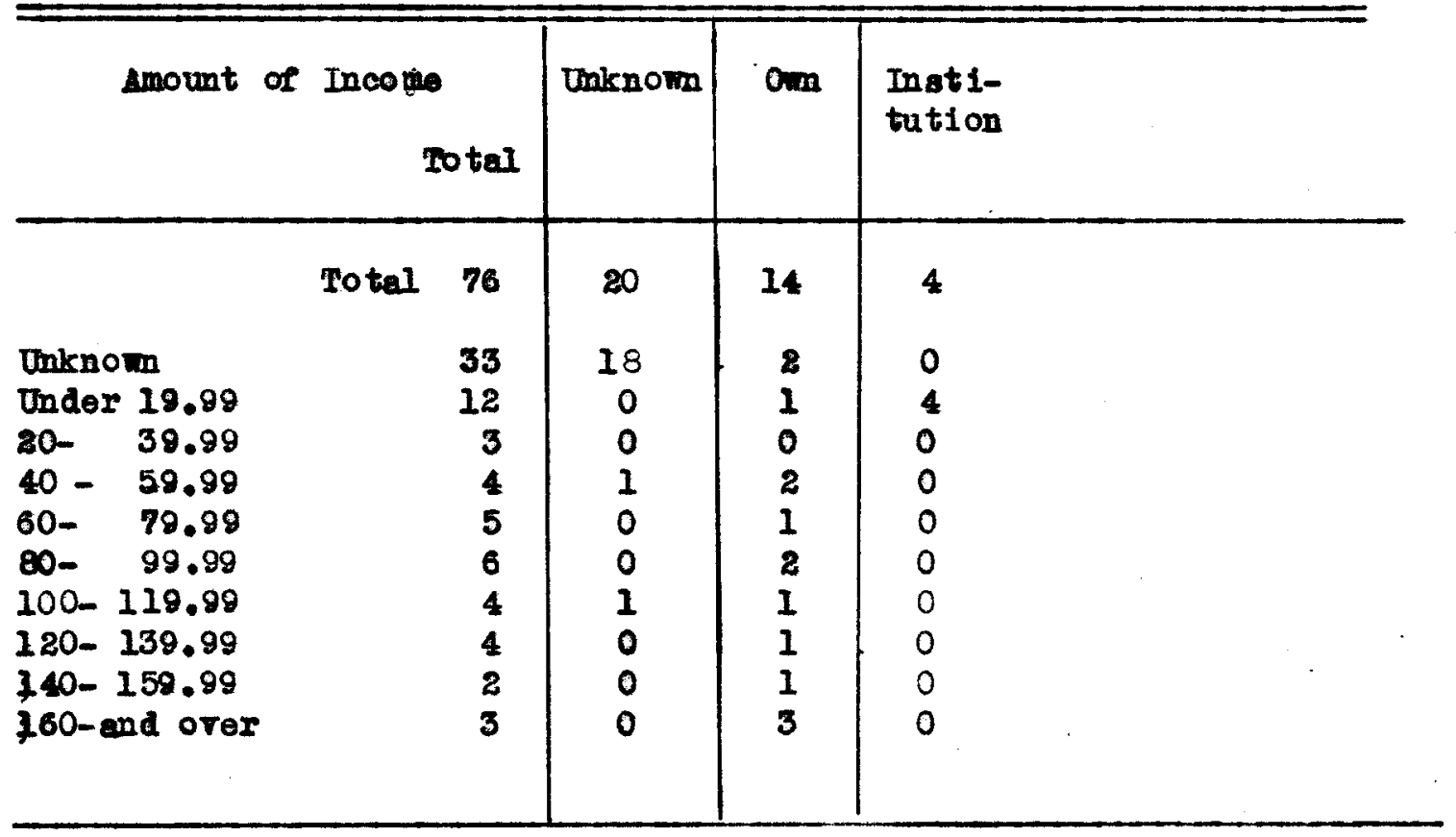

aom or buying home 
PABIS 80-Continued

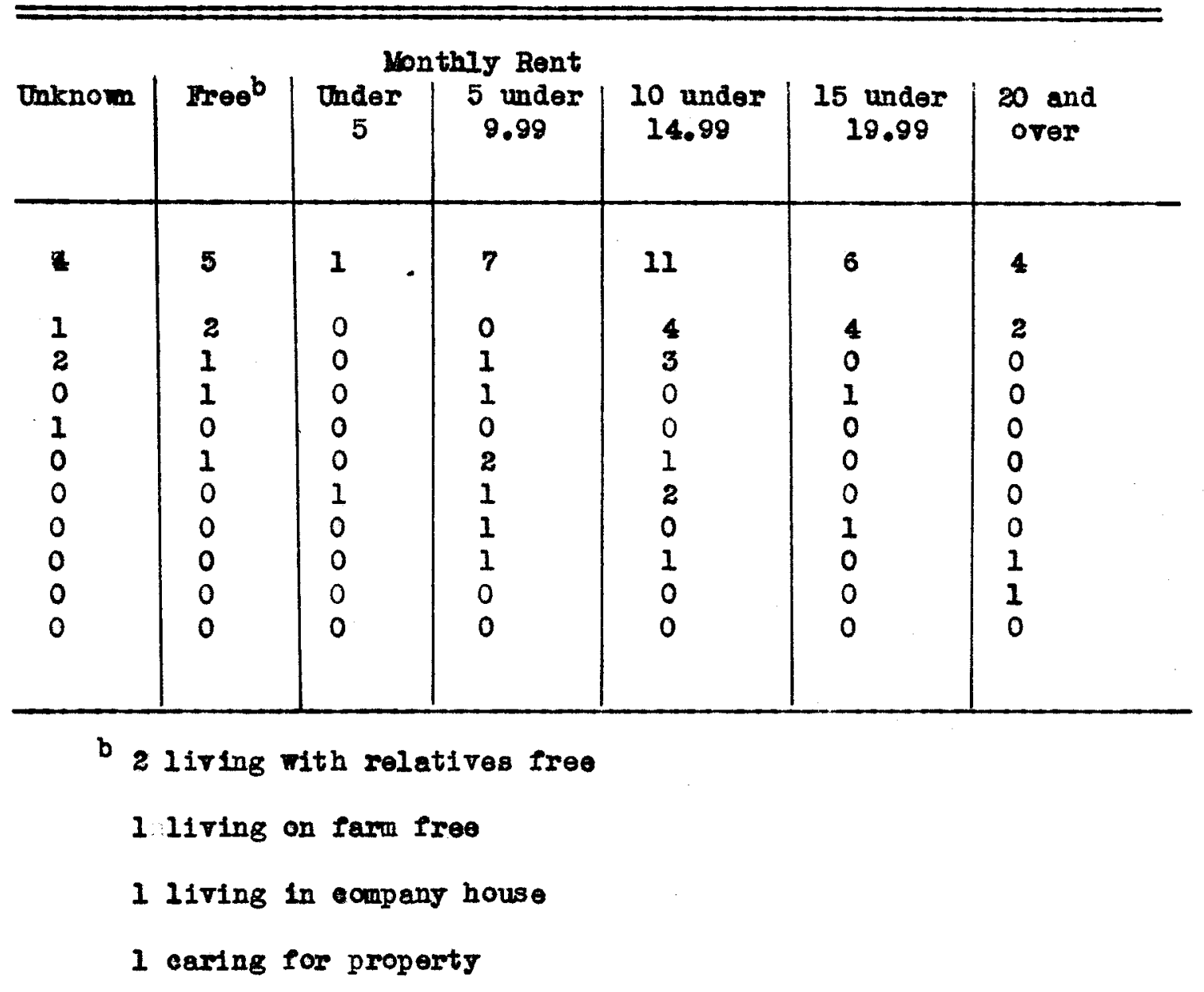

distribution by emount of income. Rentals ranged from $\$ 4$ to $\$ 39$. Five patients were living rent ree, two with relatives, one on a farm, one in a company house, and one caring for property in exchange for Eree rent. Somo of the low income patients were paying rentals very much out of proportion to their income. Three patienta with incomes of between $\$ 10$ to $\$ 20$ mere spending between 10 to \$5 for rent, or almost the ir entire incomes, while one patient 
earning $\$ 80$ pald $\$ 4$ for rent.

Some indieation of the physical condition of the home may be had Irom the mount of rent pald. Tro and 4 frooms renting for $\$ 11.45$, tho arerage, would in all probability contain fell if any modern conreniences and rould be a poor enviroment for the care of a chron1cally 111 person. Fousing has a great deal to do with maintenance of morale, health, and the hastening or retardation of an individual's rec orery.

Mary C. Jarrett used three oriteria in judging whether the home was sultable for the patients care: the physical condition of the home, Iamily attitudes (towards the patient and he torards the family), and the make up of the family (ability of the members to attend to the needs of the siek person). (y applying these stendards to the know data for each patient, not including the psychiatric, and making careful eraluation of each, eleven homes or one flfth vere found to be unsuitablo; 44 or four fifths, suitable. A home was not judged unsuitable unless at least two of the three fectors were unfavorable, except in a for outstanding instances, e.g. In one case the family attitudea and the make up of the family were satisfactory but there were eight people living in one roon, and the patient nelther had a room to himself nor slept al one. Physical condition of the home was judged by the number in the household, the number of rooms, rent, nelghborhood, whether patient had a roor to himsel $f$ and alept alone. Tamily attitudes is self explanatory, but this factor was more frequently unknown than eny of the others. Make up of the femily was judged to be favorable if there was someone to help out at home. 
The percentage of unsultable homes, one fifth, comperes farorably with that of the New York city findings in which one fourth of the patients had homes unsulted to thoir care. It is felt thet the possibility of satisfactory hawe care decreases in each succeeding age group. MEDICAL CARE IN THE HOSPITAI

All of the patients in the hospital were receiving 1 care; in other vards intensire medical study and treatment. There is noway to estimte with eny degree or accuracy the extent or intensity of treationt, but certain objective phases of, or tools used in treatment are of interest and $\mathbf{1 1 1}$ be mentioned here.

\section{TABLE 21}

TREATMENT RECEIVED BY CHRONICALLY ILL PATIENTS" ADUITTED TO LOUISVIILE GENIRAL HOSP ITAL FBBRUARY 5th THROUCH FEBRUARY 14th, 1946

\begin{tabular}{|c|c|}
\hline Treatment & Petients receiring \\
\hline $\begin{array}{l}\text { Special x-rayeb } \\
\text { Testa } \\
\text { lodicino } \\
\text { Diet } \\
\text { Sort } \\
\text { High caloric } \\
\text { Special } \\
\text { High protein } \\
\text { Diabetic } \\
\text { Cardiac } \\
\text { Liquid } \\
\text { Sinpy } \\
\text { Physlol therapy } \\
\text { Occupational therapy }\end{array}$ & $\begin{array}{ll}30 & \\
33 & \\
44 & \\
30 & \\
& 9 \\
& 2 \\
& 4 \\
& 4 \\
& 3 \\
& 5 \\
& 5 \\
& 1 \\
& 1 \\
& \\
0 & \\
0 & \end{array}$ \\
\hline
\end{tabular}

a beluding patients on psychiatric wards

bexclusive of routine chest x-ray 
Table 21 show the number of patients for whom special x-rays were taken (exclusire of routine chest plate far all patients in the hospltal), for whon various kinds of tests were made, who were getting medieaments and special diets, physical therapy and occupational therapy. Thirty patients out of 55 vere $x$-rayed, and 33 were given special tests including fluoroscope, electrocardiogram, electro-encephalogram, sedimentation tests, glucose tolerance, renal function, sternel puncture, and bone substence tests. A wide veriety of medicaments were administered to 44 pationts, Including digitalis $f$ or cardia conditions, insulin for diabetes, radium for cancer, penteillin $f$ or a variety of conditions, and adrenalin for asthma. Treatment was as varied as transfusions for enemia, therapeutic malaria $f$ cr tabes dorsalis, to mlllott treatment for chronic salpingitis. Thirty patients nere on special diets $f(x$ pert or all of their hospitalization, and these included sort, high caloric, high protein, diabetic, cardiac, and other kinds of diets.

A lerge number of operations were performed, among them: setting of a fracture, hysterectony, eystoscopy, pyelography, cervicectomy, sequestrectomy, incision and drainage (for osteonyelitis), perineal resection, bronchoscopy, dilation and curettage, remoral of carbuple, air encephalogram, exelsion of tumor, biopsy, and amputation of toe. This brief pleture of the variety of work done with a chronic patient should dispel any previousig held misconceptions that chronic disease is a non-changing, non-improring condition, upon wich anj active treatmot is rastod.

There was no record of either physical therapy or occupati onal therapy being used for any of the patients. There may have been 
faulure to record auch treatment in the medical chart, if it was given, but on the other hand, it appears that the possibilities for using physical and occupetionsl therapy with many different kinds of ailments, are being overl ooked.

\section{CIITIS}

General Tospital also cared for a good many of the city's chronically ill in the various clinics. These patients are also receiving A or intensive medic al care. Twenty-two of the 55 patients, not including the psychiatric, had attended one clinic, six petients had attended two clinics each, six had attended three clinics each, and two patients were in attendance at four and five clinics. Table 22 shors this distribution.

\section{TABLE 22}

LOUISVIILE GFNERAL HOSPITAL CL INICS ATTEIDT, RFGJAR OR OCCASIONALLY,

CTRONICALIV IIL PATIENTS ${ }^{b}$ NDIITTED TO LOTISTIILE GMTERLI TOSPITAI, FBRRUARV 5 th TIROUGH FEPRTARY 14th, 1946 (PRIOR TO FOSPITALIZATION)

\begin{tabular}{c|c|c|c}
\hline Clinics & & \\
Attended & Patients & Regular & Occasional \\
\hline Total & 25 & 15 & 23 \\
Unknorn & 2 & 0 & 0 \\
0 & 15 & 0 & 0 \\
1 & 22 & 8 & 14 \\
2 & 6 & 2 & 4 \\
3 & 6 & 3 & 3 \\
4 & 2 & 2 & 0 \\
5 & 2 & 0 & 2 \\
\hline
\end{tabular}

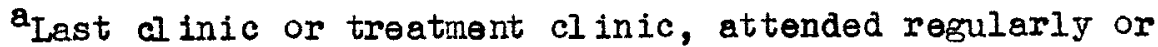
occasionally

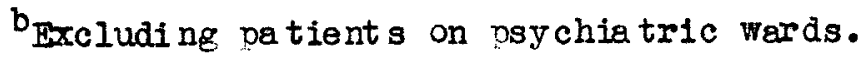


Ifteen of total patients had nerer attended any clinic, and had been admitted to the ward fram the emergeney from. Six pationts rore admitted fran bench clinic, which is the diagnostic clinic. MI new patients attend bench clinic fran where they are assigned to the varlous treatment or apecial clinics. In five cases, bench clinte was the only clinte the patient had erer attended. Fifteen petient: hed been in regilar attendance at the clinic or elinics, and 23 patients had attended occasicnaly. A patlent was said to be attending oecasionally if the frequency of attendance was unknown, If the last attendance took place a long time before the present hopitalization, or if the petient had only attended bench al Inic one time before being admitted to the ward.

It is interesting to note the correlation between ward admission and future clinic attendence. Among the 25 patients discharged to their hanes, one of the seren patients who had never attended clinic before started to attend regularly after discharge. Among the 17 petients who had attended clinic before, all but three returned, and these three had attended eccasi onally so there is the posalbility that they would return in the future. of the patients who returned, nine are in regular attendance, and five occasional. Three patients who attonded only occasionally befor $\theta$, began to attend clinic regularly after aischarge rrom the hopital. All of the patients who attended regularly before continued to do so with the exception of one patient who died.

In eveluating what happened to ward patients with regard to thoir future alinic attendance, it appears that a hospital admission had not discouraged patients fran continuing their medical treatment 
in the clinics. For the three patien ts who discontinued clinic visits, there were three patients who begen to atitend regularly. The hospital experience had had the effect of awakening one individual to the possibility of clinic treatment, but in the main, the clinics were attended by the same patients who had-visited them before.

MEDICAL CARE RECOMMENDED

The doctor of each chronically ill patient in the hospital at the time of the study, not including the psychiatric, was a sked to state his opinion about the type of future care that the patient would be needing, and where this care should be seclireì. He was also asked whether he would recommend a chronic hospital for the patient if there was one in Louisville. Exactly one half of the 30 patients were thought to need class A care or intensive medical care, only one patient needed class B care or skilled nursing care, and 14 petients were in need of custodial or attendant care. Six of the 15 class A patients should continue at ceneral or another hospital offering facilities for intensive medical care, and the remaining nine could return to their homes and attend Louisville General Josnital clinics. Care in a custodial institution was not recommended for any of the class A patients. It was thought that the one class $B$ patient should have intensive nursing care in his own hame. El even of the class $C$ patients should bj $j_{a}$ custodial institution, and the other three could receive clinic care while residing in their om hories.

Chronic hospital care was recommended in 17 cases or over half. It was not recommended for nine or less than one third of patients, and the doctors would not state an opinion in four cases. The fact that chronic hospital care was recommenoed in orer $50 \%$ or 
cases rould appear to be a good argument in faror of a hoepital in Louistille spocializing in the treatment of chronic diseases. Seren class 4 patients, one class B patient, and nine class C patients were said to need chronic hospital care, as shown in table 23. Such a hospital should therefore be planned in proportion to the tyes of care needed, having half of its beds reserved for clase or custodial patients, almast half for class $\Delta$, and a small number of bede for cless B. ilecommendations for psychiatric patients by type of care needed and place where this care should be secured are shown in table 24. PATIFNTS PLANS FOR MEDICAL CARE

The patients in the wards were asked what their probable discharge plans were, excluding the pogehiatric, and what plans they would prefer if conditions were such thet they could have a cholce of plans. In 25 out of 30 cases, probable plans and desired plans were the same. In nine cases the patients plans ineluded returm to work soon after discharge, but as pointed out in the preceeding. discusion on employment, not more than, and in all probability less than $50 \%$ of these patients would be returning to work. This estimate is based on the patients last period of employment, prognosis for recovery, and the very low proportion of patients already discharged who were known to have returned to work. It appears therefore that at least half of the patients who included employment under "probable plans" were really stating their "desired plans" and were not giving enough thought to the reality factors in the situation. Four petients stated that they preferred other plans to the ones they had been able to work out. All four desired in- 


\section{PABLE 23}

IYPE OF CARR RECORIENDED FOR CHRONICALIY

IIN PATIRNIS ADMITTED HO LOUISVILIT GENERAL HOSPITAL FEBRUARY 5th IFROUGH FEBRUARY 14th, 1946 BY WHETHER CHRONIC HOSPITAL IS INDICATED FOR THAIR CARE (PATIENTS ON NARD AT TINE OF STUDY)

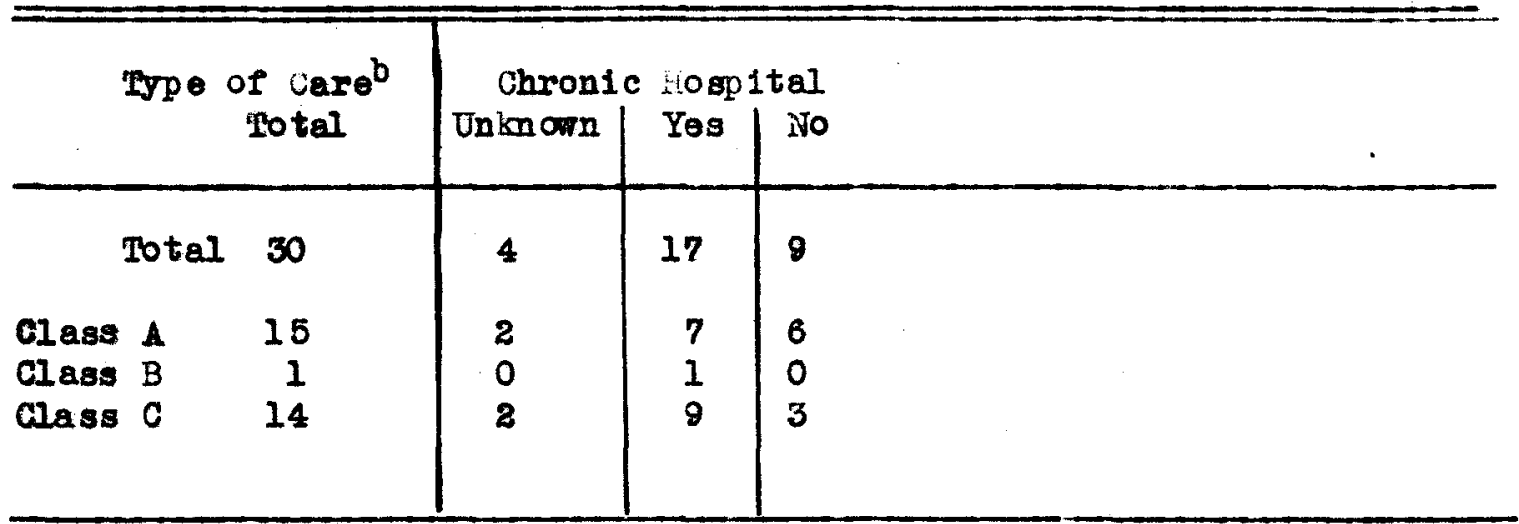

aproluding patients on psychiatric wards

bclass a care is intensive medicel study and treatment which may bo secured in a hospital, or at home by a private physician, city physicien, nursing service, or in a clinfe.

Q asa B care is skilled nursing care which may be secured in a hospltal or at home by a nursing service.

Class C care is custodial or attendant care which may be secured in a custodial institution or at home if home conditions are suitable. 


\section{TABI:E 24}

TYPE OP GART RECOMRENDED FOP PATIENTS ON THE

PSYCHIATRIC TARD. ADITTED FEBRUARY 5th

IHROUGH FFBRU, $3 Y$ 14th, 1946, TO

LOUISVIILE GENERAI HOSPITAL BY

PLACE WHERE THIS CARE SHOULD BE SECURED

\begin{tabular}{|c|c|c|c|c|c|c|}
\hline Type of & Care ${ }^{a}$ & $\begin{array}{l}\text { Continue at } \\
\text { LGr for in- } \\
\text { tensi ve medi- } \\
\text { cal care }\end{array}$ & $\begin{array}{l}\text { Hon } \\
\text { Little } \\
\text { Nursing }\end{array}$ & $\begin{array}{l}\text { Inten- } \\
\text { sive } \\
\text { Nursing }\end{array}$ & Clinie & $\begin{array}{l}\text { Custod- } \\
\text { Ial } \\
\text { Inst1- } \\
\text { tution }\end{array}$ \\
\hline To tal & 21 & 2 & 0 & 0 & 6 & 13 \\
\hline $\begin{array}{ll}\text { Glass } & A \\
\text { Class } & B \\
\text { Class } & C\end{array}$ & $\begin{array}{r}8 \\
2 \\
11\end{array}$ & $\begin{array}{l}2 \\
0 \\
0\end{array}$ & $\begin{array}{l}0 \\
0 \\
0\end{array}$ & $\begin{array}{l}0 \\
0 \\
0\end{array}$ & $\begin{array}{l}6 \\
0 \\
0\end{array}$ & $\begin{array}{r}0 \\
2 \\
11\end{array}$ \\
\hline
\end{tabular}

aclass a care is intensive medical study and treatment which may be secured in aihospltal, or at hame by a private physician, city physictan, nursing service, or in a clinic.

Class B care is skilled nursing care which may be secured in a hospital or at home by a nursing service.

Class C care is custodial or attendant care which may be secured in a custodial institution or at home if home conditions are suitable. 
TABIE 25

CHRONICAILY III PATIFNTS ${ }^{\circ}$ ADMITTHD TO LOUISVILCE

GHNERAL HOSP IEAE FIEBRUARY 5th THROUGH FEBRUARY 14th, 1946

ON TARD ATTDEE OF STUDY (PROBABLE DISCHARGE PLANS, DISSIRED DISCFARGR PLANS, WHETHIRR SOMEONE IS AT HOME TO HELP OUT)

\begin{tabular}{|c|c|}
\hline $\begin{array}{l}\text { Probable discharge plans Total } \\
\text { Unknown } \\
\text { Convalesee } \\
\text { Return home-not work } \\
\text { Return home, work } \\
\text { Othexe }\end{array}$ & $\begin{array}{r}30 \\
1 \\
3 \\
15 \\
9 \\
2\end{array}$ \\
\hline $\begin{array}{l}\text { What patient wo uld desire } \\
\text { Unknown } \\
\text { Same as probable } \\
\text { discherge plan } \\
\text { Different from pro- } \\
\text { bable discharge plan }\end{array}$ & $\begin{array}{l}1 \\
25 \\
4\end{array}$ \\
\hline $\begin{array}{l}\text { Someone to help out at home } \\
\text { Yes } \\
\text { No }\end{array}$ & $\begin{array}{r}26 \\
4\end{array}$ \\
\hline
\end{tabular}

areluding patients on ps jchlatrie wards

bInoludes two institutional cases

Evoterans hospital, Institution in Paducah

stitutional care in preference to returning to thatr an hames; a nura Ing bowe for con, Home for the Aged and Infirm $f$ or mother, and two, church homes (one specifled a catholic home). Two of the ward patients who came from institutions would return thore, and two others planned to enter institutions; one a Veteran's Hospital, the other an institution in Paducah (This patient had poliouyelitis). These are included under "probable plans" in table 25; the inst1tutional cases under "retum hone- not work", and the two planning to enter institutions under nothern. 
Three petiente stated that they mould convalesce for a wile, one in his onn hom, two at the home of relatives. It is signif1cant that the patient wo planned the fullest convalescence, two or three months, was the one wose income was considerably above the median; \$148.

Lmost all of the patients, 26 out of $30 \mathrm{stated}$ that they had someone at home to help out.

Trentyfire discharged patients, not including the psychiatric, were risited in their homes in en effort to learn what kind of adjustment they were making and whether they were still under supervision in the treatment of their chronle condition. only ono elehth or patients hed returned to work. It loast 15 patients were attending clinie, anong them one who had never attended clinic befar e. Three patients who had attended clinic prior to hospitelization did not retum. Only two patients were seeing a prirate physician. Only one petient was ut ilizing the services of a public health nurse fron Viaiting Nurse Assoclation. Two other patients received nursing care at the institutions of which they were inmates. One institutional case at Home for the Aged and Infirm for twelve jears was transferred to Faverly Hills Sentitorium, and plens were belng made to transfer the Kings Daughters patient, an inmate of this inst1tution for sixteen years, bedridden and suffering from anemia for twenty five years and spinal degeneration for seventeen years, to Central State Hospital. (She was noisy and offensive to the other inmates and had delusicas that she was Mrs. Booserelt.) Nineteen of the 25 patients had someone at home to help out, and eleven were taking medicaments. Institutional care had been con- 
sidered in only one case among the petients at home, but application had not been made. (As stated abore, two $p$ atients still in the wards planned to enter institutions). The above date is shown in table 26 .

\section{TABLE 26}

PLANS TO CONITINUE MEDICAL CARE OF CHRONICALLY IIL PATIENTS HOSPITAI FEBRUARY 5 th THROUGH FEBRUARY 14th, 1946 , DISCHARGED FRON HOSPITAL AT TIME OF STUDY

\begin{tabular}{|c|c|}
\hline 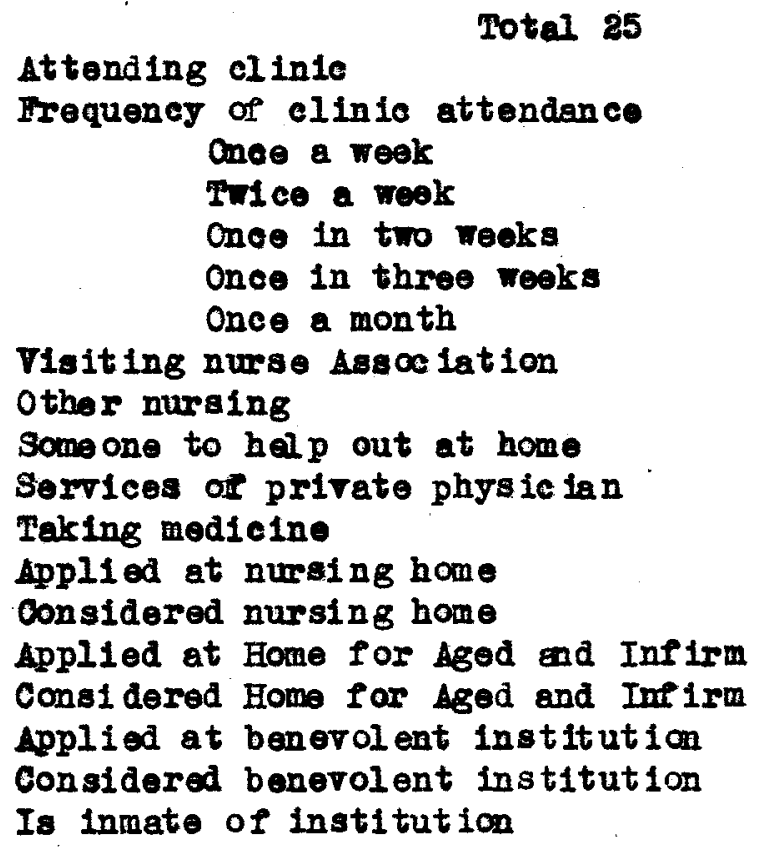 & $\begin{array}{c}15 \\
1 \\
1 \\
1 \\
4 \\
1 \\
2 \\
1 \\
2^{b} \\
18 \\
2 \\
11 \\
0 \\
0 \\
0 \\
1^{c} \\
0 \\
0 \\
2^{d}\end{array}$ \\
\hline
\end{tabular}

$a_{\text {preluding patients on psychiatric wards }}$

blursing at Home For Aged and Infirm and Home For Incurables

Cliade other plans

One of these patients returned to Home For Aged and Infirm and from there ves transferred to Wavery Hills 
Pable 9 show s the disposition of the psychiatric patients. Thirteen or loss than one half had returned to the ir homes, four had been discharged to Contral state Hospltal, two had ontered muraing homes, one a private andtorium, and one a Veteran's Hospital.

Table 27 is a summery of what the patients would desire in the way of facilities for chronic care, based on the assumption that these rescurces were available. Wre petients who ind icated a preference said that they would prefer better nursing in their own home to any other ahange in their present plan. Only three patients gave a chron 10 hospital as their 1 irst cholce. (sceording to the doctor's recomendations, ehronic hospital care would be beneficial to over $50 \%$ of patients).

\section{TABTE 27}

FACILITIFS FOR MEDICAL CARE PREFERRED TO PRESHIT ARRANGEMRNI (IF AVAILABLE) BY CHRONICALIY

IIL. PAPIENTSB ADMTTTED TO LOUISVILLE GEMERAL HOSPITAL FEBRUARY 5 th THROUGF FEBRCARY 14th, 1946

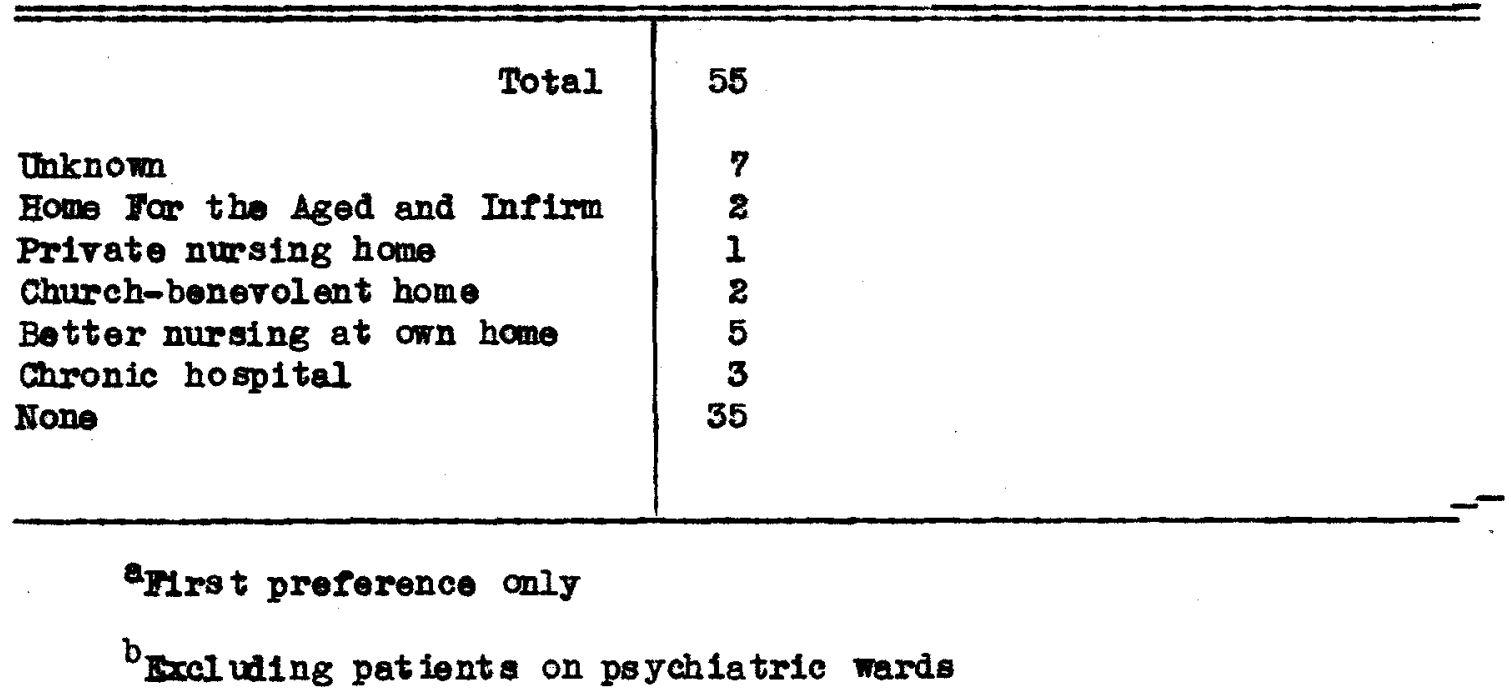


The pieture, then, is of the rast majority of medical and aurgieal chronle patients returning to their orn homes or plenning to do so, most of thom expressing satisfaction with these plans. Instituti onel care was considered in rery fer cases either because the petient was unaware that such resources existed, but more of ten because he desired to return to his own family group. Thirty elght pereent were maried. Ono diabetic patient who had had eight previous adnisaions illustrates this thinking very well. Sho stated, "I wovldn't break up housekeeping. I haven's got much, but what I hare is mine end is paid for". A fer patients associated institutional care with going mover the hill to the poor howe e". The petients who had considered instituticnal care had not seen these plans through because they had made other plans, or because they rere not eligible far care at these institutions. The patien om home was sultable for his care in 44 or four fifths of total cases. Two thirds of patients continued to receive some form of supervised modical care after leaving the hospital.

PATIENTS KNOWN TO SOCIAI SERVICE

In the Ner York City study about half of all the clmonic patients In hospitals were reported as known to a sociel worker but no attempt was made to classify the extent of service. Such a classification Is attempted here, but it must be emphasized that an entirely objective criterion to measure this intanglble does not exist. The method used comes as elose to being as exact measure of the nature and intensity of the service rendered the patient, as could be found, but another investigator might have classified the extent of service 
differently. In most social agencles a method of recording is ueed that gives some information on all people coming to the attention of the agency and records are classifled by mor service and minor eervice or by some other title to distinquish between cases that are intensive in nature and those which are short contact and involve little planning and treatment. The hospital scial service department has a somewhat different set up then the ot her agencies, es it is geared to function as part of the hosital organization and is not an aut onomous anit in 1tself. Intake or application work is not handled fran a central plece as in other agencles, but instead applications and referrals are me to the individual social workers assigned to the vartous services. The worker comes into contact with ment petients, end renders many services, but not all of these are carried and recorded as cases. The medical soe ial worker performs a variety of services ranging from a report to another interested agency on the patientig condition to intensive case work over a long perfod of time involving help to the indiridual in adjusting to $\mathrm{hls}$ iliness and in accepting the limitetions which his illness imposes. The medical social morker practices case work in a medical setting. Acting as the lialson betreen the hos pital and the comunity with the patient and his problems always as the focus, she helps the patient to discorer and utilize existing community resources.

As a general rule, cases involving intensive case work are carrled as "recorded". The rorker uses her orn jugement in determining wich cases shall be recarded and which ghell go unrecorded. Sometimes there is but a degree of difference between the 
two. Unrecorded cases in which there has been correspondence, 1.8.

a letter of referral to another agency, are filed as "correspondence". There are also those cases which are active with the worker and for wich recording is plenned but has not yet been started. These three categories, recorded or active, unrecorded (similar to the minor service of other egencies), and correspondence nere chosen as Indices of the degree of intensity ar extent of service rendered for the purpose of this study. By reading all of the recorded cases, all of the correspondence, and consulting with the workers in the rarious services about the unrecorded and active cases, it was learned thet 32 or about three fifths of the total 55 patients, excluding tho psychiatric, were known to a social worker. 4s shown in teble 28 ellmost one third of these were recorded or active, more then one third were unrecorded, and correspondenee composed the remeinder.

\section{PABLE 28}

EXTENT OF MEDICAL SOCIAL SERVICE TO CHRONICALLY

ILL PATIENTS ${ }^{2}$ ADMITTED TO LOEISVIILIE

GENERAL HOSPITAI FIBRUARY 5 th IPHOUGH FTBRUARY 14th, 1946, AS INDICATED BY FORM OF RECORDING

\begin{tabular}{l|c}
\hline \multicolumn{1}{c|}{ Torm of recording } & Number \\
\hline \multicolumn{1}{c|}{ Total } & 55 \\
Not known & 23 \\
Correspondence & 9 \\
Unrecorded & 13 \\
Recorded or active & 10 \\
& \\
\hline
\end{tabular}

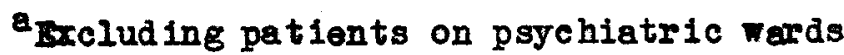


Four casesl are selected from among those wich were known to social service to translate sane of the statistics given in the body of this chapter into the problems of the individual patient, to point up the social components of the lliness, to show how the patient is effected by ohronic illness, and how he utilizes the services of the social worker. CAST NUMBER ONE

Miss $M$ is 73 years old, never married, with diagnosis of tracheobronchitis and possible tuberculosis. She complains of asthme of 21 years duration. Inis is her firds admission to the hospital although her sister Mary, age serenty-six with whom she Iites has been known to the ho 20 it al since 1928 and through the jears has been treated for upper respiratory infecticns, anxlety neurosis, chronic myocarditis, and cancer of the breast. The diagnosis of cancer was made in 1938 and an advised operation was refused by the patient.

Miss in and Mary cam from a family of ten children and were brought up on a farm. unly one of these children is still living, in another part of the state, besides Hiss and allery. When the parente died, Mary, who was elways the more aggressive of the two, sold the farm and found employment in Louisville as a seamstress. this was back in 1898 when Miss $M$ was twenty-fire jears old. Wary has always supported Hiss $\mathrm{ki}$ in exchange for which Miss Mi did all the housekeeping.

A number of years ago liary bought a four room cottage from her sevings and derived a little aditional income by renting rooms but stopped when we found that she was losing money from nonperment of rent. The sisters are stili living in this house which by now is badly neglected and mun down. The house has fow modern conveniences and toilet facilities are located in $\mathbf{a}$ out-house. Thr ough the years there has been a constent struggle to keep from losing the house. Going under the HOLC plan, they made 11.65 monthly payments until the flood of 1837 inen thoy became indebted. Also getting beh ind in eity and state teres, they were threatened with mortgage foreclosure.

Finencial assistance was secured Irom Family Service Organization, Municipal Bureau of Social Service, and St. Vincent de Paul soclety, at varlous times, and when Mary reached the age of aldy-fire, who made application for Old Age Assistance and recelved a grent of $\$ 10$ a month wich was supplemented by sewing and doing alterations on crothing. The size of the grant was changed several times, until at the present time both sistere

${ }^{1}$ all the nemes used in these cases are disguised so as not to reveal the identity of the individual. 
are receiving $\$ 10$ each. A nepher is helping by peying the expenses on the house.

Thon a young girl, Mis s M became mentally 111 and was sent to a hospital in Louls ville for treatmont. She relates indignantly that this occurred again 20 years ago wen Wary had her carnitted to Central State Hoppital for observation, but that there was nothing wrong with her. She shows s me ambivalent feelings towards her sister, on the cone hand seeming to be deroted to her, but yot making many complaints about the way Mary treats her. She projects hor sister's accusations right back to her by saying, far example, that it is Mary who is mentally unbalanced, not she. Sho was full of bitterness and hostllity as she told of Mary having her in court to pore that Misa $M$ hed tried to kill her with an ice plck. She is der initely nourotic and seoms to have some paranold trends, but is clear thinking and oriented.

The $s \propto 1$ al worker in the medicel service attempted to work out discharge plans with Miss $M$, and in conjunction with Miss M's old Ase Assistance worker. In this case we have a rery good illustration of a coperative relaticonshtp between agencies. Because the patient had made so many camplaints in the past about tho poor physical condition of the homs, and her sister's maltreatment of her, the Old Age sse I st ance worker had at three different times attempted to work out other plans with Miss M, but Miss if had not followed through on them. Arrangenents bad been made $f$ or Mis 8 to live in a nursing hame, but when she went there she left before the end of the first dev, oxpressing a good deel of dissatisfaction with the room they had given her which she describel as a "pig sty". She was then content to return to her hom with lary and her three cenaries wich she called her "bables". Anothor time Miss M was almast adnitted to the Little Sisters of the POOr, but this was held up because the pastor of her church would not recommend her, feeling that she would make trouble for the other inmates.

This time she pleaded with the worker to find her a place away from Mary, for sho was certain that if sho returned home, Mary would kill her. She preferred institutional oare, but as a secand cholee thought that she would like a room where she could "take care of children".

This patient presented a difficult planning problem. In view of her unnatural behavior patterns, neurotic trends, and general unwolesome attitudes, it is doubtful whether eny institution would accept her, or if accepting her, would keap bor for very long. She appears to be a borderline mental case, and the refore a mental institution rald probably be unsulted to her heeds. The dotor thought that a chronic hospital for treatmont of the tracheobronchitis candition wald be advisable, but after a period of hospitalization there, the ame problem of planning for the $f$ uture rould exist. Psychiatric treatment to gire the patient better ins ight into hor situation would in all probability have littlo chance for success, the pationt's age being what it is.

The social waker attempted to explare the possibilities for institutionalization more fully but had not as yet arrived at any plen that pleased the patient, when Miss $M$ suddenly left the hospital, L.0.A. (left own accord). Case work service was continued by the old age assistance worker. 
Ifis $A$ is a 18 year old, colored, unmarried female. Sho was admitted to the hospital after an aeute attack of chronic pelvic inflamatory disease after suffering pain of two weeks duration. Miss A has had two previous adnis sions, 38 days in 1939 for gonorrheal raginitis, and eight cays in 1945 for abdominal pain-undiagnosed. In the iterim she had attended pediatrie, ear, nose and throat, bench, yphilis, and gynecology alinics. She was first examined in the pediatric clinic in 1937 at the age of nine jears when the diagnosis of G.C. Taginitis and chronic tonsillitis was mado. Tho pationt continued to be followed in clinic and ras hospitalized for the raginitis condition two years later, when she was treated with sulfanllamide and improtement was notod. Treatmont was cont inued in weekly clinic visits. During the entire two years Hiss a was not attending school.

viss $A$ is one of seven children and was one of three living at home in 1939 when the case came to the attention of the social worker. Her parents had separated four years previously when she was seren years old, and a year later the mothor brought her seren children to Loutsilile. The mother had attemp ted to support the fanily through her earnings on WPA sewing project but overy 18 months when routinely laid off for two months, sh applied for assis tance rrom Family Service Organization. Several Pamlly service Applications were rejected because it was felt that much of the information supplied by Mrs A was false. When Mrs A was transferred from the sewing project to the Housekeeping Ald Division of WPA she was afraid that sho would be unable to find the homes to wieh she was sent, as she could neither read nor write.

The family in 1939 consisted of a marled daughter, fma, age twenty-four, who was separated from her husband and had been pregnent by another man in 1937. (The mother stated that $s$ he did not know how she was making her living), Richard, age twenty-one, who was not at hame and had no permanent address but wandered about from place to place, Irma, age twenty, married and out of the home, Henry, age serenteen, who lived part of the time with his paternal grendmother in another secti on of the state, Heanor, age sixteen, wo at the time of this cantact was in the surgieal ward after having an incomplete abortion, Doris, age fourteen, who attended Juntor Elgh School, and the patient, MLBs A, who was the youngest. The the youngest children, Eleanor, Doris, and Mis $s$, were living in the hom with their mother. Living conditions were extremely poor and the income, while adequate to met minimum needs, did not soem to be used to the best adrantage. They lived in one fumished room, sharing two beds. When Henry came home from his grandmother's, he us ed one bed, the mother and three daughters the other.

The mother admitted the patient's sexual irregularitios at the age of nine years. The elinic doctor thought that the patient might have become infected through the mothar, but Mrs $A$ stated that tho patient had had intercourse with a man when they first moved to Iouisfille. She did not apear to be especially coneerned about this. Sho had been working mast of the time and had to leave the children alone mast of the deg. 
The family became known to medic al soc ial service when the mother asked $f$ ar assi stance with fresh milk for the patient who was underweight. When the lacts of the situation rere revealed, the family wes referred to Family service Organlzation for super$\checkmark$ is ion in the home because of the poor moral tandards of the family. Family Servic $\theta$ Organization was active with the family from Novenber, $1939 t$ brough April, 1941 at which time the case was transferred to Iunicipal Bureau of social Service for financial assistance. Another epplication for assistance was made in 1944, at which time the mothor was in the hospital having had a stroke, Fleanor hed joined the $F_{A C}$, and the petient was doing domestic work.

This case is good illustration of how a broken hame, poor housing, inadequate income, and Inadequate parental supervision lead to promiscuity, martial unhappiness, economic dependency, with permanent physic al and moral demage to its mombere. The germ for Nises A's chronic candition started to incubate in 1935 with the separation of her parents. The pattern is consistent with that described for many of the gynecological conditions in the early part of this chapter; early sexual promis euity leading to gonorrheel infection eapocielly in young Negro momen in the low income groups. The disease process also seems to follow regilar pattern an early acute at tack going untreated, follared by another attack with fever that causes the rictim to seek medical adrice and treatment with the sulfa drugs. At the time the polvic examination fails to show up any abnormalities (note that the 1945 admission was $f$ or abdominal pain-undiagnced). From $s$ ix months to three years later there are definite strue tural changes folloned by frequent attacks. This stage occurred $\mathrm{s}$ ix months af ter the 1945 adnission for Miss A.

Fe cen predict, for Miss $A$, if the development of her disease continues to be in conformity with the pattern, additional attacks increasing in sererity until she is forced to give up her job and at which time surgery may be recommended. The adhesions will always remain and may be revived by such precipitating factors as childbirth and reinfection. At the present time, patient is in the period of lull before the storm breaks again, is employed, and hes no complaints.

\section{CASE NUMBER THRER}

Mr $K$ is sixty-five years of age, never marriod, with diagnco is of luetic heart disease, acrtic insufficiency, and conjeative inilure. The patient has had this condition for 17 years and has had six previous admissions to Loulsville Ceneral Hospital totalling 87 days. Including the present hospitalization, he has spent 97 days in this hospital. In the period between hospitalizations since 1940, he has attended medical elinic regularly.

During the petionts second hospitalization in $1942 \mathrm{Mr} \mathrm{K}^{\prime} \mathrm{s}$ is ter, Mrs. Young, consulted the social worker, appearing very upset as she stated that she could not give the petient a home, and sho did not know how he could manage. She operated a rooming house but did not have room for her brother. Wr Young was employed in a factory. 
No $K$ had been living alone in two rooms in the bank of a shoe repair shop sined the death of his mother a year befare. She hed received an old Age Assiatance grant and the patient had never married, stering at home to take care of her. Ho did occasionally share these room with a young man wo was away at work all day, but he ras al one most of the time. The patient had been employed as a craftsmen- a maker of bells, until the heart condition became incapacitating. A brother in Detroit sent money for food.

Two years later, in 1944 the patient aplled for sunicipal Bureau of Social Service aid, and in 1946 he became ellgible for ald Age Assistance. Mr K had four living sibl ings, Mrs Young, another sister in Louisville, and brother and sister in Detroit.

In 1842 plans were discussed with the petient but he thought that he could manage well at home, and although he had two interested sisters he stated that he did not wish to live with them.

Contact was intained with $\mathrm{Mr} K$ during his frequent admissions, one in January, 1943 and three in 1944. In 1943 ir K atated that he would like to make oplication $\mathrm{fa}$ the Home for the Aged and InIIrm but shortly af terwards his sister, Mrs Young, and ber husband came to Ilre with lif $K$ in tro rooms which had been opened into Mr $k^{\prime} s$ two rocms, making a four room apartment...and although the $s$ is ter was orippled from varicase velns, sho was able to do onough work to enable Mr $K$ to rema in in bed or sit in a chair most of the day. Nir $k$ therefore decided not to enter the Home for the Aged and Infirm at this time.

The following year the petients condition became more serious. He had three adnissions for decampensation. During the first of these admissions Mr $K$ had two heart attacks in the rard, and there was difficulty in getting his swelling down. When bo left the rard ho was adised to have very limited activity and to try to get someone to live with him. hr end hrs Young had left his home and he was staying by himself ond dolng his crin cooking. It was at this time thet referral to Municipal Bureau of Soc lal Service was made, as the patient had attempted to do a few odd jobs to supplement the help he was getting from Mrs Young and the brother in Detroit.

The petient continues to live alone, doing the housekeeping and preparing his own meals, following his cardiac diet strictly. The two rooms are kept spotlessly clean although the furniture is old and raded. His hands shake, he is becoming more and more foeble with time, and there will undoubtedly come a time when the petient will hare to plan for institutional care. During the present hospltalization it was noted that his stay was unerentful, his condition upon discherge somewhat improved. It is felt that with proper medication and sufficiont rest this man can get along fairly well. Ho will no doubt be reedmitted to the hospital at various times due to recurrent decompensation, and would be an excellent candidate for a chronle disease hospital, needing a (intensive modical) care and $C$ (custodial) care at different times.

CASE NOMBER FOUR

Misa $\mathrm{R}$ is a twenty-five year old colored female, with diagnos is of sickle cell anemla of nine years duration. She has had eight 
previous admissions, 88 hospital days, and two additional admission While this study was in progress, or a total of 112 Bospital days. Wis o $R$ merriod very yaung and has been separated from her husbend for ten years. Her father died when she was twelve years old, her mother whon she was $s$ ix years old. She was one of seren children. The petient's conditi on is such thet she must come to the hospital $f$ ar frequent transfusions and she is also being trested with liver injections and jeast capsules.

inls case was presented at a medical student conference in 1943 as an example of a situetion in thich a patient with a recurrent disease has learned to live wi th her disease, managing very well both from economic and $s \propto$ ial standpoint. At that time sho did not appear to be concerned about her condition and was taking fairly good care horself. She lived with a sister and worked when she was able as an elevator operatcr, coasionaliy doing domestic Fork. Because ber sister provided her with a home, Miss $R$ was able to go to bed whenerer ahe was not feeling well. The family had rover been known to any soclal agencyl As she appeared to be meking a good adjustment ot her illness, no services from sccial service were required.

The situation has changed 8 ince the patient was known in 1943. Miss $R$ is now living alone in room renting for $\$ 4$ month. Sho is employed as a scrubwom in a hotel when she is able to work, but more Irequently she is confined to her bed due to extreme weakness and severe eramping in her legs. When admitted to the hospital this time she was delirious and camplained of pains in her head and back. In the ward she cried most of the time and dis turbed the other patients. So great has been the change that it almost appears as though this were another petient and not the same one who in 1943 had no complaints and had learned to live with her disease. It is surprising that she has not had to seek public assi stance all this time. Chronic hospital care would be an excellent plan for this patient. 
CHAPTER III

COMMUNTTY RESOURCFS FOR MELTING TTE NGEDS OF TUE CTRONICAILY ILI. 
COAMUNTY RESOURCES FOR METTING THE NEEDS OF TEE CHRONICALLY ILL

"ihe outstending factor in the situation of the chronic sick is that wherever they are, they are almost always in the wrong place: ${ }^{I}$ Are Louistille's chronic sick "almost alvays in the wrong placen because the community has failed to provide the "right placen for them? In the foregoing chapter we sam what the probleme of the chronically ill are, and their needs in the way of medical care. He shall now consider how the community is prepared to meet these needs, what the facilities are, whether they are sufficient, and what the areas of unmet needs are.

For social, even more than for medical expediency, the patients own home is considered the best enviroment $f$ cr satisfying the needs of the individual petient, unless unsatisfactcry home surroundings or a serious medicel conditi on calling for hospital care dic tate otherwise. The Hew York City survey of 1928 found that one fourth of those living at home should have been in ingtitutions. ihe patient at hane must either be able to visit the clinles at the hospital or else have his medical care brought to him by a city visiting physician, since we are considering the medically indigent group who are unable to pay for a private physician.

CLINICS

Louisville has an excell ent out-patient department set up with special clinics for many of the chronic diseases, but unfortunately the physicienls indifference to the chronic diseases is often carried over into the clinics. From observation it would appear that this is more true of the generel diagnostic, medical, surgicel, and orthopedic olinics than it is of the other special chronic disease clinics 
wich are often staffed by doctors especially skilled in the treatment of these diseases. It was found in New York City that as many patients were attending clinies who needed C care, as were those in need of A care. If the sam thing is happening here, and it appears that it is, this might be one factor accounting for the doctor's lack of interest in the chronically 111 clinic patient. Clinics are intended to give intensive medical treatment as is the in-patient departont, with the exception that the patient does not need to go to bej. Because of the tremendous volume of work, only patients who are 111 and who can be treated are acceptea, theoretically. Clase C patients are those ho have reached a staticnary point in their 11lness and to nhom medical treatment can be of no benefit. It is therefore an abuse of clinic facilities when class $C$ patients continue to be treated at the various clinics. Each clinic has a quota, and for every person who is seen in clinic with out benefit, enother person may be turned away who could benefit.

Louisville General Hospital does not have a separate cancer clinic, but there is one located at St. J cseph's Infirmary where x-ray treatments are given. CITY PHYS ICIANS

C1ty physicians are provided for those patients who are unable to attend clinics but for whom hospital care is not indicated, on a prolonged basis as long as neoded for indigent patients, and only in case of energencies when a private doctor cannot be found

\footnotetext{
$1_{\text {Rosenfield, I. op.C1t., p.50 }}$
} 
for those patients who can afford to pay for the service. The city physicien set up follows one of two general outlines; they are either drawn from a panel and paid by the visit, or are engaged on all time or part time salaried basis. The chief defect of the panel system is the lack of supervision. The other system seems to be best, especially wen the city is divided into districts with one or more physictans responsible for each district. A plan of distriet physicians is in force in Louisville and suburban areas. The city and county is divided into five districts, three thite and two Colored, with a physician on a part time salaried basis assigned to each district. There is also a list of available physicians located in each district tho may be called when the regularly assigned physician is unable to make the call. ihe directar of the Bureau of Medical Care with offices in the city and county health department building also makes many visits himself. Wonthly reports on the calls made are sent to the director. There were 3,825 home cells in $1943,3,253$ in 1944, and 2,041 in 1945. The declining number of hane visits each year may be partially explained by increased ability of people to pay for private physician care. Requesta for the service are relayed from the hospital (General Hospital itself does not have a staff of visiting physicians), or come from the patients themselves. Meny illnesses are treated by the $\nabla$ isiting physiciens, and it is estimated that orer ten percent of tot al home visits are made to chronically ill patients. NURSING

Another Iopprtant phase of home care far the chronically ill is a nursing service. In almost all communities the nursing service 
consists of that operated under manicipal auspices and service bought from or contributed by the roluntary organizations already in the $\mathrm{fis}$ ld. In some cities where there are a number of roluntary organizations there is a good deal of duplication resulting in the fallure on the pert of the public to understand and utilize the service. A rather clear cut distinction exists in Louisville between the Public Heal th Nursing Association (Health Department) and the Visiting Nurse Association, with the functions of each service clearly defined and duplieation pretty well ruled out. Misunderstanding arises occesionally between the public health nurse the the $s \propto$ ial worker orer the division of responsibility but on the wole there is good cooperation. There also appears to be same friction between the hospital nurse and the public heal the nurse but it is not of such serlous nature as to affect the health of the patient.

There are three types of nursing service; the visiting nurse, the health department nurse, and the practical nurse tho is untrained and gives only bedside care. The visiting nurse, or public health nurse as she is properly called, is a graduate, registered nurse with additional public health training who gives coplete nursing service including bedside numing and a certain amount of educational work wi th the patients and their families. Visiting Nurse Association in Louisville is a communtty chost opported agency, but also derives a portion of its income from patients' fees and fram several Insurance compantes who pey far the nursing care of their industrial and group policy holders. One dollar and fifty cents is charged for a visit of an hour or 1ess, and $\$ 2.50$ for an 
appointment $\nabla$ isit when the patient can afford to pay, but there is a fee scale depending upon the patient's abllity to pay and many patlents are served free of charge. In 1943 it was estimated that chronic cases comprised two percent of total cases, and nine percent of totel visits for that year. Distribution by major disease groups, cases, and $v$ is its, was as follows:

TABLE 29

CERONIC PATIRNTS CARED FOR BY VISITING NURSE ASSOCTATION BY CASES AND VISITS, LOUISVIILE KENTUCKY, 1943

\begin{tabular}{l|c|c}
\hline \multicolumn{1}{c|}{ Pation ts } & Cases & Visits \\
\hline \multicolumn{1}{c|}{ Total } & 252 & 5,120 \\
Cancer & 72 & 3,600 \\
Pheumat1s and Arthritis & 50 & 300 \\
Anemia & 10 & 50 \\
Heart & 90 & 480 \\
Nempitis & 8 & 80 \\
Senality & 20 & 88 \\
Crinppedic-congenital malformations & 2 & 522 \\
& & \\
\hline
\end{tabular}

In adition, 750 visits were made to fracture cases. In January, 1945, Visiting Nurse sssociation s tated that while records are not kept to give a breakdown of information into chronic and acute cases, two percent of total patient load is a conservative figure for chronic cases. A yoar later, in March, 1946, 1t was estimat that about twalre percent of total viaits are to chronic patients. There is no Iimit to the number of visits that may be made to one patient. The nurse continues her wark until she is no longer needed, or untll she has taught the patient or a member of his family how to carry on. 
It is not necessary that the patient be under a doctor's care in ell cases, but for such things as bladder irrlgation, dressings, hyperdermic series, the nurse gets her orders directly from the doctor in charge of the patient. The vis iting physic ian service and sometimes the clinic service is more effective if nursing service is arailable at the same time. Unfortanately, there seems to be too little contact between the physician and nurse rorking with the same patient. They rarely see the natient at the same time and do not get the benefit of each other's observations.

New York City's Visiting Nurse Association in 1938 made the same percentage of home visits to chronic patients, about ten percent It wes felt that the number did not rep resent all of the chronically ill who needed nursing care, but rather that it $r$ epresent ed the total number that Visiting Nurse Association could acc codate. The pressure of acute work and health teaching kept the services of the Visit ing Nurse Association down to a minimum. Visiting Nurse Assocition in Loulsrille is fully staffed again after the war period and feels that it can serve as many patients as are referred to it. The Association is disturbed by the fact that so many ehronic cases are referred so late, when the condit ion bas become really serious. It would like to have the opportunity to do some of the preventive aspects of the work. Their foeling, backed by experience, is that if they do not get the chronic cases early, they will surely get them later on. Although it is felt that the edueational work of the Nursing Agency reduces the amount of time that can be given to the bedidie care of the chronically ill petient, it has a direct relation to the prevention and reduction of chronic illness and has 
more beneficial effects in terms of the future.

Apperently then, the need in Louisville is not for an expansi on of the Visiting Nurse service, but for better utilization of the existing one. Public education is probably the best way that this could be accomplished, and the Association foels that early repcrting of cases known to the rerious social agencies, as well as more referrals from General Ho spital would be an effective way to introduce the chronically ill person to a nursing resource. The health department nurse has little ta do directly with the care of the chronically ill person. She is primarily concerned with the promotion and protection of health, and kes routine home visits only in cases of communicable disease. A graduate, registereā nurse, some of her functions under the city- county health program are:

a. Home risitation of cases of acute communicable diseases for educational purposes.

b. Assi sting phys icians at tuberculos is, veneral diseases, - and pre-natal clinics, and home visitation for finding cases and for instruction of patients in the rome.

c. Assisting physician with organization of and teaching in infant and pre-school conferences.

d. Assisting with examination and supervision of school children and securing needed treatment and corrections for such children.

e. Promotion of group education through clesses in home care of sick child care,nutrition, Iirst aid, etc; trough informal talks with mothers, talks to groups, and through assisting 
with all projects for arousing public interest.1 HOUS BKCHAPING AIDIS

Clinics, city physiciens, nursing services, meet the medicel needs of the chronically ill patients living at home, but other things are needed to render the home a suitable place for the care of the chronic patient. For the women who is afflicted with chronie diserse there is a real need for a $f$ om of hassekerping service to rel leve her of the burden of cleaning her house, cooking, doing the leundry, and numerous other tesks so necessary to the maintenance of a hous ehold. The problem is espectally severe if she has no one at home to help out, and in the case of persons living alone.

In 1935 a housekeeping aid experiment was tried in New york City to explore the possibilities of home care for chronic patients, to gain experience in the use of housekeeping service for this purpase, and to determine its desirability as a permanent part of a public assistance program. ihe committee of chronic Illness of the Welfare council, in cooperation with the Henry street Nursing Service under the auspices of the Lepertment of HCBpitals sponsored a WPA project for a demonstration study of home care of chronic patients. Three years later, a similar WPA housekeeping project for home care of recipients of Old Age Assistance was merged with 1t. Patients were referred by 30 medicel and $s \propto$ ial agencies includ ing the Henry Street Nursing Service. To be eligible an individual had to be chronically ill, active with a social agency,

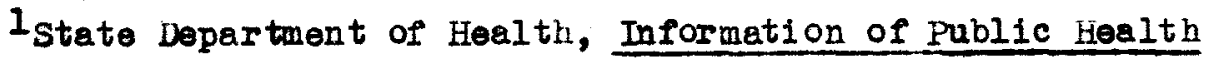
Nursing. Louisvill $\theta, 1944$ 
recelving medical care from a physician or clinic, and in the low income brackets. Preference was given to patients who were being kept in city hospitals because there was no way of caring for them at home, in an effort to learn whether suitable arrangements could be made for them with housekeeping service. It was demonstrated that many patients could be cared for at home in this way who otherwis $\theta$ would have to remain in an institution. Not only did the patient benefit from this service, but so did the entire household. There were 807 patients served in a two year period. Among the benefits oberved were improved home conditions, preservation or nomal relationships in family life, increased confort and contentment for the patient, and improvement in health. Serenty five parcent of the patients were living with their fanilies, ten percent Iived with relatives or Iriends, and $15 \%$ l1ved alone. The average hength of time the patients received housekeeping service was 7.4 months.

The housekeeping aides ware women referred by the Fome Relief Division of the WPA, who were given a preliminary instruction course before going into the homes of the patients. They were regarded as an "aide" and not a maid" and their function was to help the family to maintain normal home conditions but not to relieve the well members of the patient's famlly of their responsibilities. Duties of the housekeeping alde included cleaning, cooking, washing clothes and 1roning, and personal service. The service was given in half day units of three hours, and the average unit of service given per patient was 4.8 half deys or about two and one half days a week. Housekeping aides were paid 
prevalling WPA rate of about 4.46 m hour. Including supervision and administration, the service cost approximetely $\$ 3$ a day per housekeeper. The cost of service per petient, withour overhead expenses was an average of $\$ .92$ a day. To leern whether hame care for chronic patients under a housekeeping aide program was less expensive to the city than institutional care, the average daily expenditure per patient for medical care, \$.157, nursing care .016 , drugs and apliances .07, and housekeeping service .92 were added together, amiving at a total of \$1.16 a day, exclusive of overhead and administrative cherges. Institutional care would probably cast the city considerably more.1

This study is cited as an example of what can be accomplished In the way of housekeeping service to halp the chronic petient to Iive comfartably in his own home. The greatest impeliment to the establishment of such a service in Louisville at the present time is the current shortage of womanpower. Few women are willing to accept positions as housekeeping aldes so soon after the lucrative pasitions they held during the war years. The purpose of the program, which is to help the chronically ill to maintain thelr ofm homes, the close supervis ion, and strict eligibility for service, are same of the features that distinquish it from a domestic employnent service.

SOC IAI AGENCIES

Financial assistance by a relief agency is in a great many cases essential to the plan of home care for chronically ill people.

IJarrett, Mary C., Housekeeping Service for Home Care of Chronic Patients, Report of a WPA Project in New York City. New York, December, 1938. 
Poverty be a precipitating factor causing or promoting the devel opment of chronlc illness, but the carollary is more often true; economic dependency arising fron the chronic illness. In the New York City study almost half of the chronic cases were reported by non-institutional agencies, and about half of the families served by family agencies had a problem of chronic illness. The average period of care by one agency was two years and nine months. The cost of caring $f$ or those who became permanently disabled was enormous. Clients of an agency come to its attention usually because of finencial noed, but the responsibility of the family egency goes beyond in uncorering the causes that led to the need and in offering gidance and assistance to the Individual. Chronic patients often require social service more frequently then do others, and for longer periods of time, since they need to adjust themselves and their circumstances to the ir disability.

In this study over half of the patients recelving public assistance were elients of Old Age Assistance, the program of federel and state ald which came into existence with the social security act. We have seen that the size of the grant is in no way related to the noeds of the sick individual; nevertholess in half of these cases it was the individual's entire source of income. Municipel Bureau of Sociel Service, the public relief agency for residents of Louisville, was helping $f$ ive eights of Individuals receiving public assistance. The County Welfare department was active with one family wo, by residence, did not qualify for municipal Burrau of sociel Serrice aid. 
In the fiscal year 1939-1940 Huncipal Bureau of Social Service reported that $31 \%$ of the ent ire "singlen case load (which constituted $40 \%$ of the entire load) were chronically ill and in need of care not available to them in their own homes. An additional four percent of Individuals in the single case load were bedfast. Many cases required medical care, special diets, and bed rest, and arrnagements were made to care for the bed patients, the very feeble, and those requiring institutional care, at the Home for the Aged and Infirm.

In its report for the fiscal year 1943-1944, Muncipal Bureau of Social Service states that the chronically ill or incapacitated formed $88 \%$ of its relief loed. In the two previous years this Iigure was $87 \%$. The agency reported a smaller number of the aged and of families with dependent children wo would quality for the federal-state Ald to Dependent Children program in 1943-1944 than ever before. "The large majority of the chronically 111 remain year after year".1

social agencies also serve the chronically 111 by investisating cases that apply far care at some of the institutions. The county Wel fare department investigates all applications for the Jeffers on County Home for the Aged. The Hunicipal Bureau of Social service has had the ir function of investigating all applicants to the Home for the Aged and Infirm since 1931. Femily Service Organization

$1_{01}$ ty of Louisville, Annual Report of Department of Wel fare, for fiscal yoar ended June 30,1944 . Louisville, June, 1944, P.19. 
since February, 1946 has taken orer the function of investigation, temporarily or until a medical $s \propto$ iel worker cen be secured, for the Kings Daughters Fome for Incurables, investlgating all nem applicants and giving casework service to an occasional patient already in the hane when there is need $f$ ar a change of plan. INSURANCE

There are several different kinds of insurance that help the insured chronically 11 person by easing the financial burden imposed by prolonged illness. All forms of insurance rork on the principle of spreading the risk. None of the patients in this study had hospitalization insurance to meet part of the cost of the hospitalization. Fight individuels had a form of sickness and accident insurence, but in only two cases was this a major part of their income. Most policies include a maximum reeks of payment clause, and chronically ill people are usuelly 111 or inccapacttated for longer than this period. Another very common regulation is that the individual be a bed patient to qualify for benefits. Chronically ill clinic patients, although they may be bedfast or partially embulatory most of the time, are ineligible for payments. This form of insurance is therefore a resource for few people.

On a larger scale, and for people aged sixty-five and over who have been in "corered employment", ar their survivors, beneIi ts are avaliable under the old Age and survivors Insurance program of the social Security Act. Illness is not a requi site for

1Taylor, Esther. K1ngs Daughters Home for Incurables, Memo to executives of social Agencies. February, 1946 . 
this benefiti but of course, many of the people sixty-five years and over who qualify have sane farm of chronic disability. The plen was set up and differs from Old Age Assistance in that it makes possible a continueti on of income ofter retirement. Insurance is paid from a fund contributed by workers and employers and every individual sixty-five years and over who has been in corered employment and who is "fully insured" or "currently insured" according to the definition of the act is entitled to such benefits, the amount varying with total vages and number of dependents. Ass 1stance grants, on the other hand, are financed entirely out of tax revemues and are paid on an individual budget basis. The insurance program has benefited a smaller number of people than the assistance progrem bocause many people under the former have not as yet accumulated the necessary quarters of coverage to make them "fully insured" or "currently insured". There are many potential beneficiaries who will draw when the insurance program becomes inore fully matured.

It is not the purpose here to describe fully the various features of the OId Age and Survitors Ins urence progrem except as it rel ated to the chronically ill aged sixty five and over. Some provisions of the law are being studied by legislators and administrators in an effort to seek liberalization of provisions which currently exclude large groups of the population. Several proposals arising out of such study would have a direct effect upon the chronically ill, and include extended coverage, more adequate benefits, and $d$ is ability benefits payable to wage earners under sixty five. It is this last proposal that is of special 
interest to us here. Wany workers are forced to leave the labor market due to chronic illness before they reach the age of. sixty-five, and when they become slxty five have not accumulated anough quarters of coverage to make them eligible far benefits. "Permanent aisablement is more like old age returement. The permanently disabled worker leaves the labor market in the same sense as does the aged person; both of these classes of persons per manently cease to have earnings. The alsabled worker is generally younger than the retired worker and therefore more often has a dependent spouse and dependent children. Hence, assurance of some income is at least as urgent, socially, for the disabled as far the aged." One posible solution to the problem would be the reduction of the age of eligibility for those workers who becone disabled before the age of sixty five.

Another wey to meet this need is by expension of the present social security program to include new forms of social insurance; insurance against wage loss through temporary or permanent disability. Wore than one hundred bills were introduced in the present congress offering various schemes for the liberalization of benefits and the inclusion of new forms of insurance in the present social security set up. A compulsory health insurance program formed the major portion of these. Health insurance plans w111 be further a1scussed under the section rederal participation".

Unemployment compensation is another provision of the social security act which seeks to offset the effects of temporary unemployment. Intirely state administered, with amount of benefits and perlod of coverage varying from state to state, a common pro-

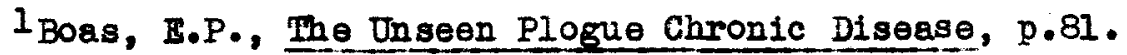


vision in all states is that the individual to qualify must be willing and able to work, but unable to find suitable work. A person unemployed $f$ ar reason of illness is autconatically disqualified. As the bill stands, people unemployed because of chronic illness are ineligible for benefits under this program. However, there is a bill before congress proposing addition of payments for temporary disability to the unebployment compensation system. Rhode Island is the only state who has such a provision now in effect. If pessed the "temporary disability" feature pould exclude a large number of chronicelly ill, but there would be some who might qualify. VOCAIIONAI RERABIIITATION

The feder'al-state social security program of vocational rehabllitation helps an individual with a physical or mental impairment constituting a vocational hendicap.through its rehabilitation services to be restored to productive capacity. Now under the Federal Security Agency and the state departments of vocational rehabilitation of the departments of education, the program got its start in 1920 with the passage of the rehabilitation act, "an act to provide for the promotion of vocationel rehabilitation of persong disabled in industry or otherwise and thoir return to civil employment.rl

The scope of the program was expanded with the rocational rehabilitation amendments of 1943. By 1944, fifty states and territories had made plans for vocational rehabilitation programs.

Isocial Seourity Board, Compllation of the Social Security Laws. Washington, D.C., 1941. p.35. 
Kentucky was ane of the flrst states to accept the federal provisions, and in July 1922, exactly two years after the beginning of the federal program, received its first federal appropriation.

To be eligible, a person must be of employable age, must have an employnent handic ap by reason of disability, the disability must be considered to be remediable (if it can be substantially reduced or eliminated within a reas on able period of time), the individual must be unable to pay far the services in whole or in part, and the individual must be rendered employable or more advantageously employable through $r$ ehabilitation services. A complete program of rehabilitation includes: finding the disabled, modical and rocational dlagnoses, advise and counseling in helping the individual to evaluate his assets and liabilities, causes of his present problems, and in taking steps necessary to correct these difficulties, physical restoration including all forms of prosthetic appliances, vocational training, maintenance and transportation for some individuals, placement in employment, and follow up.l

In 1934 in Louisville it was recommended that the Kings Daughters lome for Inc urables be converted into a vocational guidance institution for handicapped young people. SHELTERED WOKK

Some of the chronically ill are able, without rehabilitation services, to be employed but cannot face the open competition in the labor market. Sheltered workshops offer a solution to this

1 Federal Security Agency, Annual Report of the office of $50-$ cati onal Rehabilitation 1944. Government Printing Office, Wash ington, D.C., 1940. pp.1-11. 
problem by providing work on a non-competitive basis for the handicapped person. This is one of the functions of the sheltered workshop but not the most important when considered from the standpoint of the limited salaries offered. It also serves to rehabilitate persons not eligible under the federal-state program. The . sheltered workshop in Louisville, coodwill Industries, one of a number located in the various states, peys its trainees about $\$ 14$ a week end its workers starting at 16 a week, depending upon need. Marrled workers with dependents receive higher pay. Sheltered workshops therefore do not free the patient entirely.from the economic hardship brought on by the chronic disease. The other functions of the sheltered workshop, besides providing a work opportunity far thase who cannot compete in industry, include training for a job suited to tho individual 's handicap, and proHlaing industrial convalescence where the individual may learn to adjust at his own pace. Nore important than actual finchcial romuneration is the maintenance of morale and the feeling of confidence it gives to the patient.

Sheltered workshops are not the entire enswer to the problem. They are, as a rule, limited in the anaunt of ork they offer and the number of pobple they mploy. They rerely pey for themselves but must be hearily subsidized. It is difficult to remore the competitive element entirely ond there is a certain amount of presure felt by the patient as he attemp to to gear his output to that of the fellow working on the next bench. An effort is made to place the individual in the type of work that he will enjoy but this is not al ways successful. Job monotony is a frequent cam- 
plaint as so many of the jobs require piling and sorting and other routine tasks. It is necessary that the individual be made to feel that he is doing an important, worth while job, and that the job hate status. This is especially true if the individual's pattern has always been one of independence and assumption of responsibility. Heanor Cockerill points out that in terms of psychosomatic moening, s ane jobs offer few satisfactions to the individual and retard rather than promote his return to normal status. 1

Two groups of people are eligible for treining and employment with Louisville Goodwill Industries; the disabled who after a period of training will be capable of seeking employment in competitive industry, and those mose disabilities make it impossible $f$ ar them to meet the demands of competitive employment and who will remain in the shel tered wokshop. Facilities are limited and preference is given the first group. The agency uses the following guide in accepting clients: (In order to preference).

For Group 1:

1. Orthopedic disabities - age: 18 to 29 years

2. Visual or hearing disabilities - 890 : 18 to 29 years

3. Orthopedic disabilities - age: 30 to 39 years

4. Visual and hearing disabilities - age: 30 to 39 years

5. Cardiac and related circulatory disorders - age:18 to 39 years

6. Arrested tuberculosis and rel ated respiratory disorders age: 18 to 39 years

7. Ipileptic and rel ated nerrous conditions - age: 18 to 39 yers 8. Any of the abore specified disabilities - age: 40 to 64 years For Group 2:

1. Orthopedic dis abilities

1 Cockeri11, Heanor, Institute on Psychogomatile hedicine. Louisville, Ky., March 30, 1946 
2. Mpilepoy

3. Cardiac and related circulatory disorders

4. Visual and hearing disabilities

5. Neurotic and related nervous disorders

6. Arrested tuberculosis and related respiratory disorders

In the month of February, 1946, according to the service report of the executive secretary, 88 persons were employed. They

were classifled according to disabilities:

TABIE 30

DISABILITIES OF PERSONS MAPLOYED

AT GOODFILI INDUSTRIES, FEBRUARY, 1946

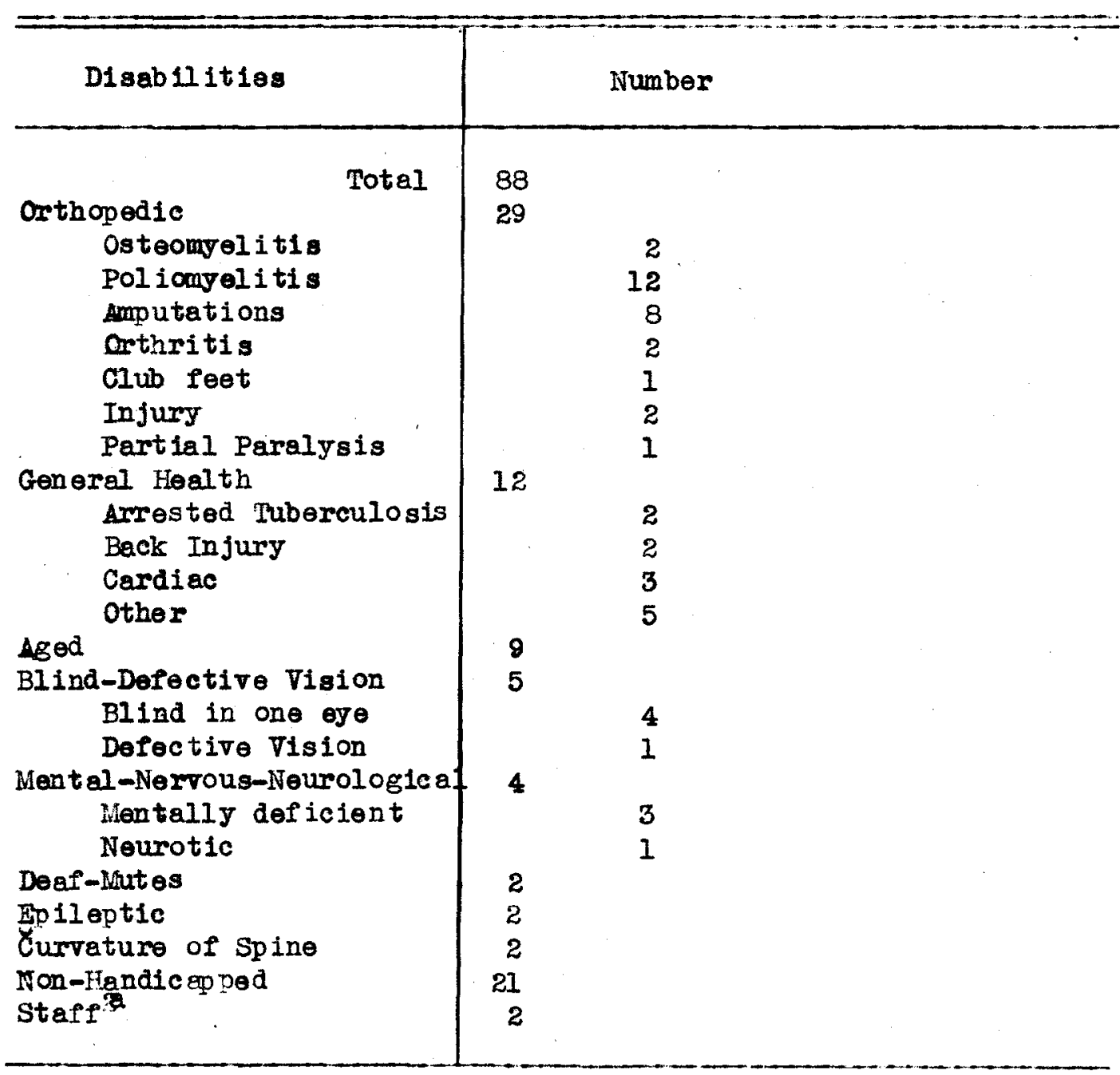

Awo other staff members are included in Hand ic apped persons. 
The work classification of these 88 persons Fere as follows:

TABLE 31

WORK CIASSIFICATION OF PERSONS WMPLOYED

AT GOODNIII INDUSTRIES, FEBRTISPY, 1946.

\begin{tabular}{l|c}
\hline Work Classification & Number \\
\hline \multicolumn{1}{|c|}{ Total } & 88 \\
Trainee & 15 \\
Shelt ered Work & 48 \\
Non-Fendic apped & 21 \\
Staff & 4 \\
\hline
\end{tabular}

The list of trainable trades and skills at Goodwill industries is

Impress 1ve:

Maintenence

Ironing, sewing, and talloring

Mill in $\theta$ IY

Doll rehabilitation

Cooking and kitchen management

Brush refinishing (painting, staining, rarnishing, shellacking, bleaching)

Spray painting

Food shop - gen eral

Clerical -- general office work

Stove repair and refinishing

Laundry

Dry cloaning

Steem press

Shoo repale

Upholstering

Store management

Genoral mechanical repeir (sewing machlne, vacumm sweeper, locksmithing, otc)

Gock and watch $r$ epair

Rad 10 repair

Cabinet shop - antique reproductions and $r e p a$ ir

Traffic control

Statistical

Inventory c ont rol

Switchboard

Graphotype

Addressograph

Nultilith

Mimeograph

Postage meter machine

Ediphone operation 
Telephone solicitation

glovator operation

Low pres sure $f$ ir emen

Appraisal and pricing

Toy repairing

Wany referrals come from the Office of Vocational Rehabilitation which uses Goodwill Industries a good deal for the vocational tratning phase of their work.

The materials used in the various trades are, in the main, sal vaged goods, and the finished product is distributed to the nine Goodwill stores throughout the city to. be sold at reduced price.

Louisville Goodwill In austries does not arrange transportation far 1 to employees, nor dos it have a program for home bounds (people confined to thoir homes), although it would like to develop this phese of the ir program as has been done in Dayton, Oh 10 with 47 home bounds. All work is done at the central plant loceted at South Elghth Street.

CRRONICAICY IIL CTIDREN IN TIEIR OTN HONGS

For chronically hendic apped children of school age the Board of Education has a division of special classes equippod to meet the raryine needs of the handic apped who cannot attend or would derive no benefit from regular classes. The re are seven sight saving classes for 112 children with impalred vis ion offering first grade through junior high work. The four classes for tho hard of hearing are graded by age, and accomodate $32 \operatorname{chlld}$ dren. One teacher is arailable for speech eorrection work with about 250 students. There is also one cach teacher who instructs groups of children who are normal mentally but rotarded in certain subjects. Three classes are held for orthopedic and cardiac cripples (in- 
- luding spastics). There are 65 students in these classes. One class is held for chlldren who are behavior problems, classified by age and range: There are 33 students in the 14 classes for the mentally retardod.

These children all live in the ir own homes, and carfare to the school is provided when the family cannot afford it. Orthopedic and cardiac cripples are taken to schools by taxi. There are also the children with disabilities including rhoumatic forer, nephritio, congenital deformities, poliomyelitis who cennot leave their homes wi thout denger to their health, and for whan home teachers are provided. The Boerd of Education has three full time and one part time teacher who give home instruction to 60 students, risiting each child about once a week.

Two teachers are assigned to Childrens Free Hosp1tal, Jewish Convalescent Home, and Koseir Crippled Chilarens Hospital, to work with the children, who, during the long perfod of hospitalization, have fallen beh ind in their school work.

The Boerd of Bducation's division of special classes gives at least 800 handicapped chlldren the opportunity to have as good an aducation as the healthy child, and in some cases makes it possible for children to remain in the ir own homes who might otherwise have to be in institutions. Institutional care for children is more common for social than for modical reasons. It is pretty generally accepted that hame care, even of infertor quality, is preferable to institutional care for the child who has living relatives. There are exceptions to this rule, of course, and it is these exceptions who fill the childrens institutions, aside from the orphened. 
Chronic illness among children besides bringlng unhappiness and suffering to the child, is of great concern to the community because thoir illness will be of longer duration than that of the adult population, and they are of potentially greater expense to sciety.

FOSTER HOMES

Foster home care for physically handicapped children as well as for the aged, then their own homes are unfit, is a plan that has been too little developed in Louisville. Substituting $f$ ar the patient's own hare, it offers the advantage of family life, and is a means of circumenting institutional care. "Fos ter home care for physically handicapped children is more expensive than fos ter home care for healthy children, but less expensive than institutional care for sick children." Th The use of foster homes Ix the care of these two groups has been successfully demonstrated in several cities, including Boston and Clevelanà. NURSIIG HOMES

Nursing or boerding homes do not properly belong under the title "institution"; actually they represent the intermediary plan, holf way between the home and the institution. A boarding or nursing home is a private home operated on a profit basis, 夜ich has been adapted to the care of aged, ill, convalescent, or homeless people. Rule 1, section 4 of the rules end regulations govern ing nursing homes in Loulsville, defines a nursing home, "incl udes homes, convalescent homes, homes $f$ ar the aged, and

IJarrett, Mary C., "The Care of the Chronically Ill", Hospital Survey of Nen York. Vol.II, Chap. XI, 1937. p. $67 \overline{9}$. 
similar institutions and establishments in which two or more persons are cared for with or without hire, gain or reward, such petients rechiving care beyond that which is usually given in hotels, lodging and boarding houses, wherein a meid, attendant or nursing service is required for the care of patients beyond and in addition to the usual teid service rendered by a hotel, lodging or normal boarding house, but not incluaing institutions listed by the American Medical Associati on as hospitals, and not including establistments caring only for patients related by blood or marriage to the operator or person in active charge of such home, home for the aged or similar establishmont. nl

The nursing home started out as a place for aged people who were not chronieally ill, but who were too old to take care of themselves. The increase in the number of aged in the population, and the fact that these aged people were often without family ties, had a direct bearing upon the development of the nursing home. The social security Act in 1935 gare some financial status to the aged, and comIng as it did during the depression, when many people were seaking by renting rooms and other means to supplement their meagre incomes, the aged were welcomed with open arms and the nursing homes began to flourish. (In contrast to the present day when Old Age Ass1stance recipients are turned aside in faror of the wealthier clientele) Wily rooming housekeepers evicted their unemployed to make room for the "pensi oner" tho could pay cash".2 In exchange for the old Age

${ }^{1}$ Louisfille and Jefferson County Board of Health, Rules and Regulations Coverning Nursing Homes. Louisville, $\overline{\mathrm{KJ}} \cdot, \mathrm{July}, 1944$.

2Wagner, Margaret, "Nursing Homes Care for Rigid Supervis ion", Hospitals. March, 1945. p.52-56. 
Assistance grent, the aged individial was given his meals and a room which he shared with several otherg. It was not reelized until later on that the aged person was very often a chronic dibease sufferer, and that he needed medical supervision as well as a roof over his head. Even now, the primary function of many nursing homes is to provide shelter rather than any form of medical care.

The next step in the development of nursing homes, in order to combat the evils of the early period, was the introduction of regulatary laws and licensing procedure. New York in 1909 was the first state to require licensing of nursing homes. By July, 1945, fourteen states had such a regulation. The licensing procedure and the controlling body varies with the state. In onestate it is done by the Board of Control, in another by the Public Welfare Council, and in another by the Board of Public Welfare, but in eleven states it is the responsibility of the state department of public or s $\alpha$ ial welfare, with controls varying from simple super$\nabla$ is ion and licensing to very elaborate requirements.

New Jersy, one of the early states to establish control of nursing homes by licenses (in 1927) has one of the most progressive 1ars. A graduate nurse in each home, and the regular attention of a physician are required. After the sys tem had been in operation for a little mile, New Jersey candidly surreyed the situation and found that with rising cost of living, and a greater number of individuals with incomes considerably higher than that of the old Age Assistance recipient, who could pay more for nursing home care, the Old Age Assistance recipient was being excluded from the 
nursing home, or else wes crowded into one room with several others to make it worthwile to keep $\mathrm{him}$. Most of the recipients were receiving the maximum amount of $\$ 40$ allowable under the social security program, (50\% federal, $50 \%$ state money), but this was not enough to buy decent care for them. It was felt that the federal maximum was tending to pull dow nursing home standards. New Jersey, a woal thy state, then decided to supplement the $\$ 40$ with money of its own (state and county), al though it would not bring an increase or federal money, and the grant, figured on a budget deficit basis, was raised, over a five year period, to $\$ 70$ for people living in nursing homes, pius additional emounts for clothing and personal expenses, drugs, unusual amounts of surgical dressings, etc. The accepted going rate for Old Age Assistance patients in nursing homes in New Jersy is $\$ 70$. Removal of the ceiling on Old Age Assistance grants has resulted in better nursing home care for Old Age Assistance clients. In 1944 approximately 410 persons or $1.6 \%$ of the old Age caseload received grants with wich to pay for care in licensed nursing hanes.

At the Baker Memorial in the Massachussetts Ceneral Hos pital the social worker assumes the responsibility for inspecting the nursing homes used by the hospital. Chlcego established a central service for the chronically ill under the auspices of the Institute of Medicine in 1943, with one of 1ts ma for functions the supervision and development of good nursing homes. The Benjamin Rose Institute In Cleveland has been responsible for the development of good nursing homes through supervision, and it has also establishod a small nursing home for the aged incapacitated by chronic disease. 
The Board of County Commissioners in Cuyahoga County, Oh10, sponsored its own nursing home as a division of the County Relief Bureau for its totally disabled relief clients.

Louisville did not adopt regulations gorerning the operation of nurs ing homes, or a system of licensing until July, 1944. Some of the abuses mentioned above, were common occurrence in this city and could not be corrected until the Health Depertment was given the power of closing hones which aid not conform to the standerds set up by the lam. Note that the responsibility for licensing, setting of standards, inspection, grading, and the imposing of penalties, rests With the Health Depertment, not with the Welfare Department as in most other states, with the exception of New York City where the Department of Eospitals does the inspecting and the licensing.

Whaler the present set up, all nurs ing homes in Louisville and Jefferson County must be licensed, (See appendix 4-application for permit to operate a nursing home) and the license must be reneved every year. A practical nurse is required in the home if there are bed patients or chronic invalids. Inspection of the homes is the full time responsibility of a health department employee. The law contains very specific sanitary requirements pertaining to buildings and premises; heating, lighting, ventilation, water supply, toilet and bath facilities, food, sleeping accomodetions, and dispos al of waste. A physicien's statement testifying to the individuals dyysical condition is required of all applicants at admission. The insene and drug addicts are prohibited from entering a nursing home, but mild mental cases are acceptable. Fach hame is graded in the following monner: by kind of nursing (homes with a registered nurse 
are Grade 1, homes with a practicel nurse are Grade 2, and all others are Grade 3), and the degree of conformity to the rules and regulations pertaining to nursing homes. Homes conforming to al I the rules and regulations are given a Grade $A$ rating, those which conform to all rules of sanitation but not to rules governing buildings and premises, heeting lighting, and ventilation (one or more of these), are rated Grade $B$, and thase not meeting the $B$ requirements are graded $C$. If two consecutive inspections find that recommended corrections have not been made, the rating is lowered one grade. The low contains certain penelties including the closing of a Grade $C$ home within 30 days after warming has been given if the nursing home operator has falled to bring her home up to standard. If after the license is revoked, the home is not closed, the operator is fined for each day that she fails to do so. The law states that the revoking of licenses would not begin until one year after passage of the 1 aw in July, 1944. In June, 1945, three homes were given warning that their homes would be closed in July if they still had their C rating. One of these homes has been a particular source of trouble and has been threatened with closure many times. It did finally manage to cone up to minimum requirements.

The gredes of twenty homes in January, 1946 were as follows:

1 A - 3 idotios

$2 A-15$ homes

2 C - 2 homes

only one home, therefore, had a registered nurse in attendance, while all the others had a practical nurse. Righteen hames were complying 
with all the rules and regulations and two were not meeting the sanitary, medical, and other standards contained in the rules and regulations. Tro of the $2 \mathrm{~A}$ homes had improved from $2 \mathrm{C}$ ratings in November, 1945. The number of patients accomodated ranged from three to 32 , the median average being seven patients per home. Only two of the hames were taking Old Age Assistance recipients, and these were the two most crowded homes, having 23 and 32 patients. Seventeen homes were for mite patients, three for Negro. Elght homes took both sexes, seven women only, and only one home was for men only (a Negro home). No information is on hand on the remaining four homes. Letitia Fairfield in describing nursing homes for the chronically ill in Iondon, Fingland points out that an equally inequitable distribution exists there, with too few nursing homes in general, and hardly any for men. 1 Five or one fourth of homes specify that they oan accommodate mild mental patients. One will take cancer patients. Twelve home take bed patients; the remainder do not take bed patients.

In june, 1945, a list of the nursing homes in Louisville and Jefferson County was complled, giving sex, race, diagnosis, duration of stay, source of income (whether ow or receiving public assistancel, and condition of each patient. The data is summarized in tables $32,33,34$, and 35. There were only 14 homes included in the census, with total population of 152. In November, 1945 revisions were made when five aditional nursing homes were added to the list, bringing the total nursing home population up to 235 . At this time

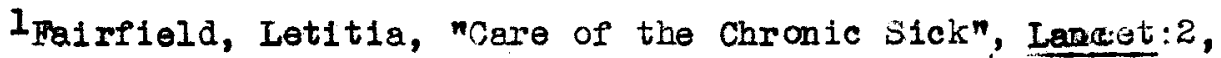
october $9,1943 . \mathrm{p} .456$. 
TABLF 32

UIAGNOSIS OF POPULATION OF NJRS ING

YOWRS IN LOUISVILLE AND

JEFTERSON COUNTY, JUNE 1945

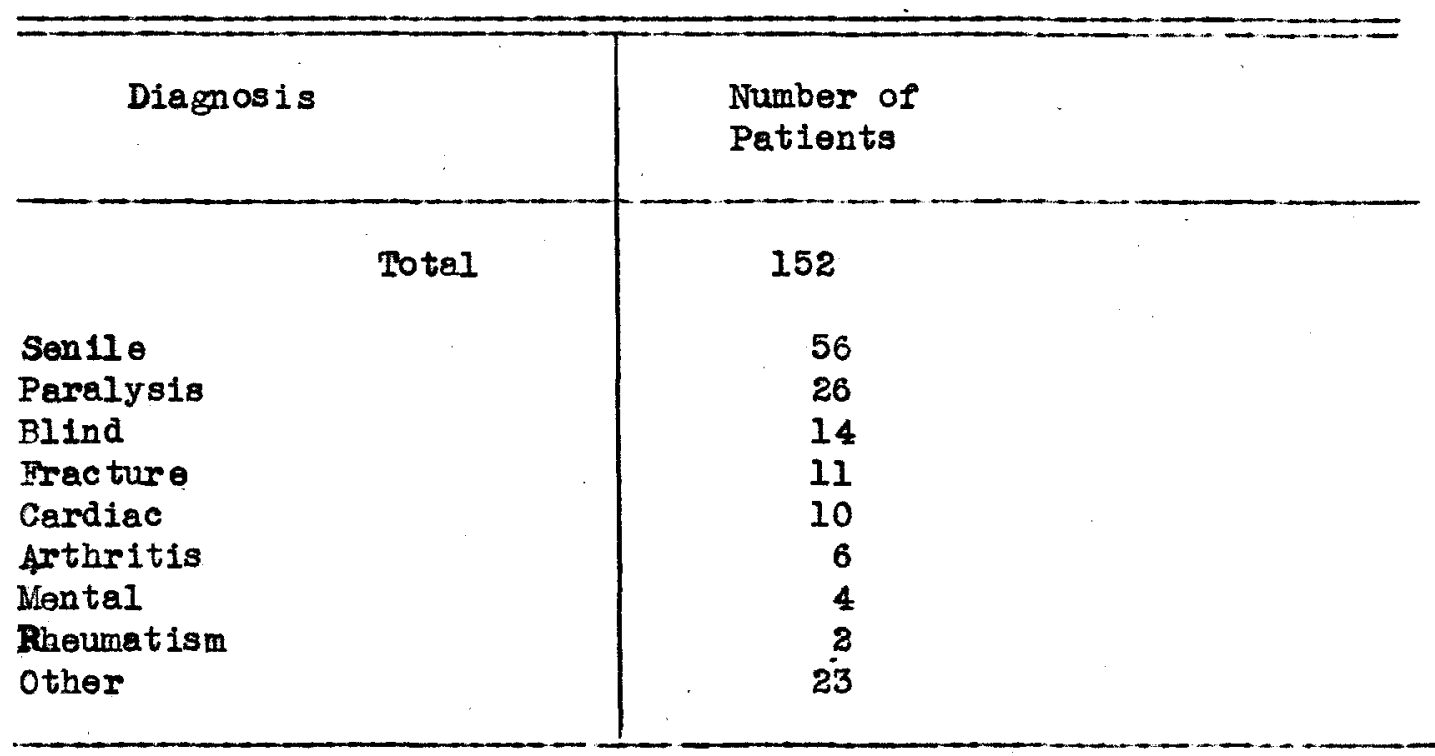

PABLE 33

DURATION OF STAY OF POPULATION OF

NURSING HOAES IN LCUISVILIE

AND J TRFBDSN COUNPY JUNE, 1945.

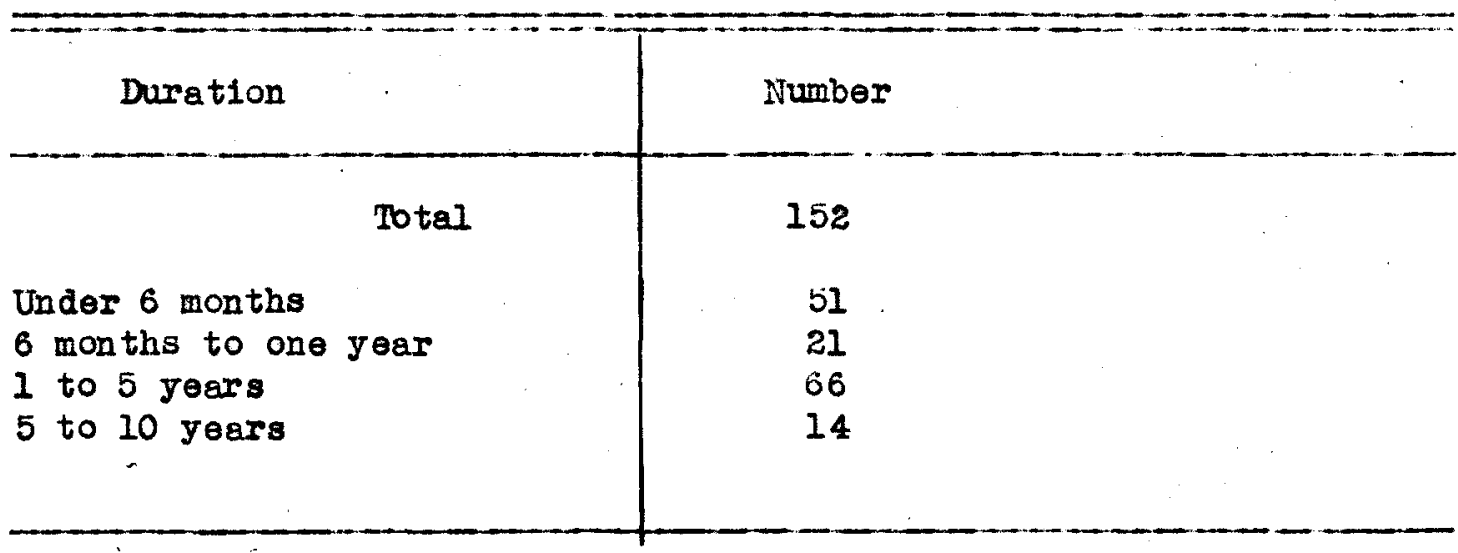




\section{TABLE 34}

SOURCE OF INCOME, ONN OR PURIC ASSISTANCE, OE POPULATION OF NURSING HONES IN LOUISUILIT AND JEFEYRSON COUNRY JUNE, 1945.

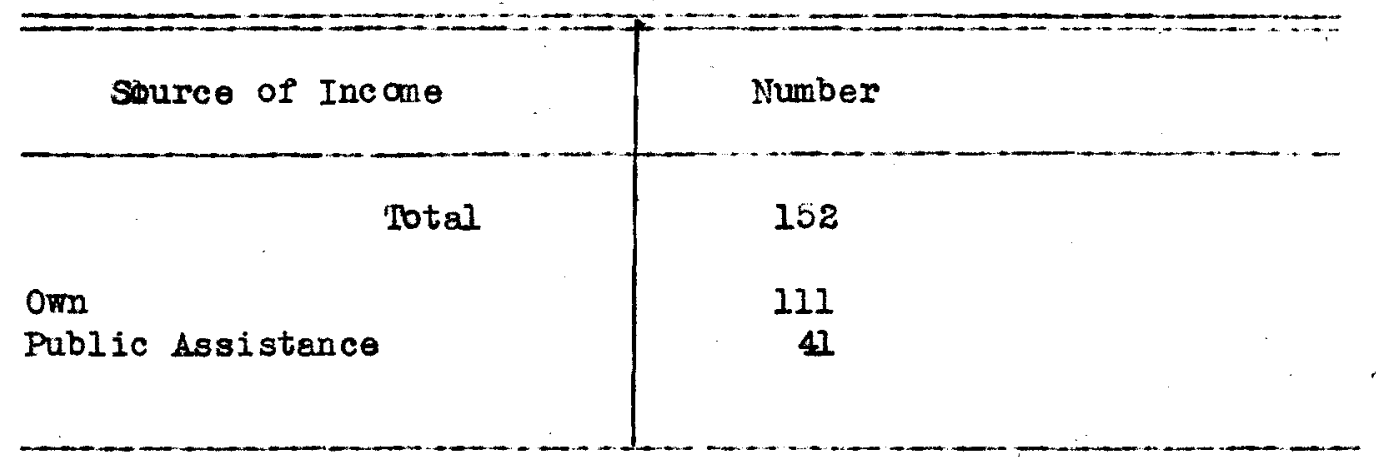

\section{TABLE 35}

CONDITION OF POPUL ATION OF NURS ING HOMPS IN LOUISVILLE AND JEFTERSON COUNTY JUNG, 1945

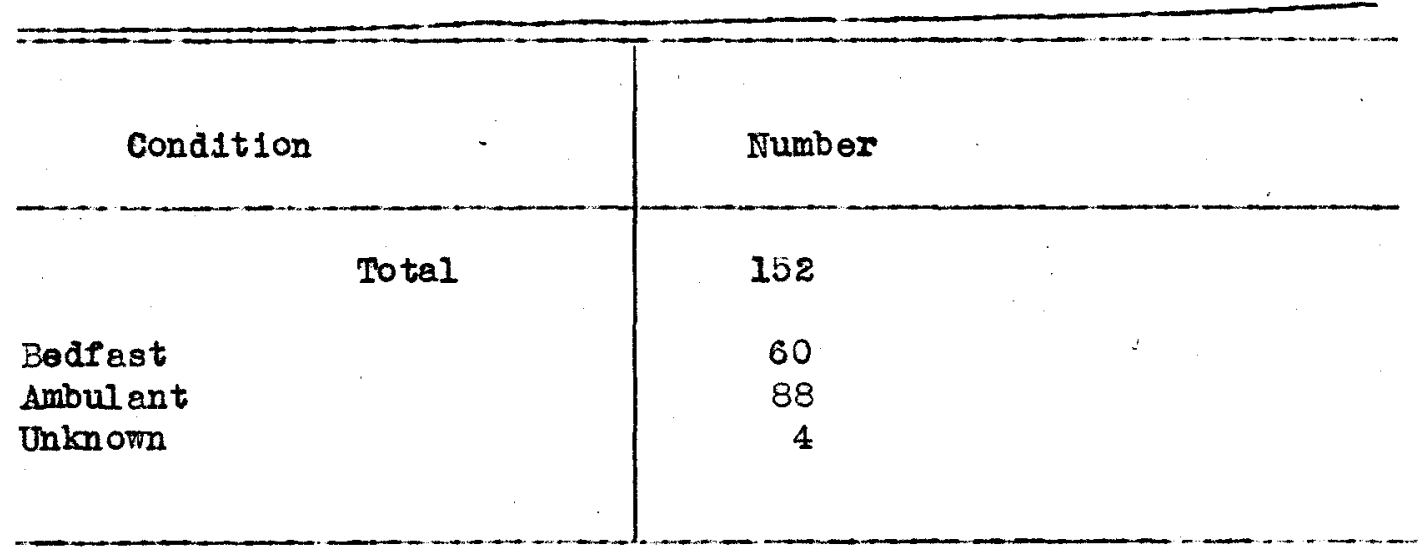


analysis was made of the types of care received, and whether the individual was a temporary or permenent resident. This data is shown in table 36. Sixteen of the total 235 were convalescents; about seven percent.

\section{TABLE 36}

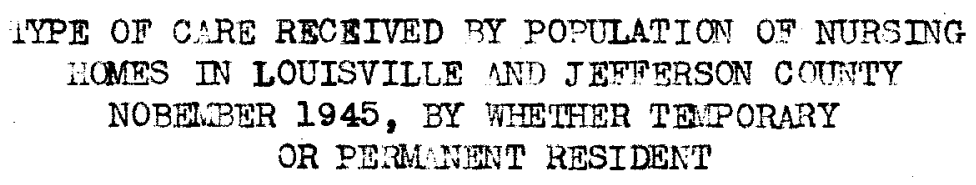

\begin{tabular}{|c|c|c|c|}
\hline \multicolumn{2}{|c|}{$\begin{array}{r}\text { Type of Care } \\
\text { Total }\end{array}$} & Temporary & Permenent \\
\hline Total & 235 & 21 & 214 \\
\hline Domiciliary & 88 & 3 & 85 \\
\hline Nursing & 53 & 1 & 52 \\
\hline Medical and Nursing & 94 & 17 & 77 \\
\hline
\end{tabular}

It can beseen that the majority of people are diegnosed as being senile; that most stay a long time, between one and five years. A great many people, admitted when they are old, remain until they die. ihe cost of nursing home care ranges from the small amount received by OId Age Assistance clients to about 125 a month. Phe average Old Age Assistance grant of $\$ 19$ a month is tumed over the nursing home operetor, and a small part of this, depending upon the size of the grant, is returned to the patient to be used for personal expenses such as tobacco: At one home only one dollar was refunded to almost all of the patients; in another the patients got to keep three dollars for themselves, one patient getting as 
much as six dollars. Hor the individual without financial resourees of his own, the nursing home might just as well not exist. The cost of nursing home care is prohibitive for most people. the quality of care given usually depends upon the number of people in the home; the sualler homes charging higher rates and giving better care. Louisville might do well to consider a plan of supplementation, with a basic fixed nursing home rate as was done in New Jersey. The only facility left for the patient who cannot be cared for in his own home, and who is not eligible for nursing home care, is the institution which is more expensive for the city. In spite of their many faults, the nursing homes care for many people who would otherwise have to be institutionalized. MUNICIPAL ITSTITUTIONS

According to the $1940 \mathrm{U}$.S. census there were 450,000 persons in institutions providing chronic hospital, custodial, domiciliary, and special care, not including the chronically ill in generel hospitals. Institutions can be classified under two main categaries: publically supported and operated, and the voluntary, endowed, benevolent, ar church supported and operated. The public institutions caring for the chronically ill are usually called homes $f$ or the aged but the assumption is that they are for the well aged. As is the case in Louisville, they are composed almost entirely of the chronically ill, and have some in the younger age groups. Wost of these institutions are equipped to give only custodial and not medical care, although the large institutions may have a separate hospital department or infirmary for the care of inmates who become ill. Serious illness cannot be treated here, however, and persons becoming serịously ill 
are transferred to a city hospital. This points up the advantage of having a custodial division of a chronic disease hospital in close proximity to the main hospital. Wo st municipal homes for the aged are survirors of the almshous $\theta$ and the poor farm and some have never had their names changed. The Louisville city almshouse became the Fome for the Aged and Infirm in 1895 but the sign at the entrance was not changed until 1935.1 The almshouse is the oldest and the most widespread method of providing institutional care at public expense. The history of the almshouse will not be gone into here except to point out that they were an of sshoot of the poor law principle of local responsibility and had their beginning as a "catch-all" institution for those for whom no other proviston could be made, including dependent children, Jagrants, alcholics, mentally deficlent, insane, and paupers; all housed together. "Its hlstoric function as the final refuge for human derelicts who can $f$ ind no other haven still moulds its policies. Medical care, not to say medical rehabilitation is not thought of. ${ }^{2}$ nover the hill to the poor house" is a descriptive lay expression in erequent use to express the feeling of the average citizen about almshouse care. The evils of the almshouse system, many of which still exist today, have attached a permanent stigma to the almshouse which makes it very difficult for many people to accept care there.

ILipetz, Irving, The Louisville Fome for the Aged and Infirm, a Study of an Institution in Transition. Unpublishod vasters The sis, Division of social Adrinistration, University of Louisville, 1942. p.51

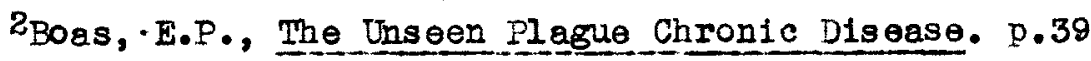


The development of the almshouse according to function can be divided into two main periods: the "catch-all" period, and the period towards conversion of almshouses into institutions for the chronically ill.

SOME FOR THE AGED AND INFIRM

The Loulsville Fome for the Aged and Infirm is a three story brick building erected in 1874 with maximum capacity of 250 . Almast all admissions to the Home have two factors in common; the lack of financial resources and the need for constant medical care. Since 1931 the Wunicipal Bureau of Social Service has had charge of admissions. Old Age Assistance also refers petients. The trend to wards increasing use of the Home for the chronically ill was recognized as early as 1930, and in the ensuing years has becone more pronounced. In $194128 \%$ of patients were bedridden as a result of chronic illness.1 An analys is of the March,1944 population showed that 192 of the population of 237 needed some kind of medical service, of these, 99 were chronic hospital patients (needing intensive medical care). Seventy four were bed patients and 25 ambulatory cases needing frequent medical attention. There were 124 custodial petients, with less serious chronic conditions. Seventy nine of these needed occasional medical attention and 45 little or no medical attentioh. The remaining 14 of the ill ponulation were convalescent cases referred fron Louisville General Hospital. All of the 120 admigsions to the Home for the Aged and Infirm during the fiscal year 1943-1944 were in need of medical care. liodical care that year amounted to $20.5 \%$ of total expenditures. 2

${ }^{7}$ Lipotz, I., op,cit., p.54.

2Annual Report of Department of Welfare op.cit., pp.4l-43. 
From May through September, 1945, a survey, including the one described above for nursing homes, was done of the public and endowed institutions in Louisville and Jefferson County. One hundred and four chronic patients were found in the Home for the Aged and Infirm. Of these 61 were male, 43 female; 65 white, 39 Negro. As in the patient study for Loulsville General Hospital, the outstanding diagnosis was cardiac disesse - Almost one fourth of the chronic population had thls diagnosis. Fractures were next in importance in order of prevalence. The medien age of the natients was 71.8 years, but there were several patients in the younger age groups, three under the age of thirty five. The oldest patient was ninety four years of age, suffering from arteriosclerosis and senility, and receiving nursing care. One of the youngest, in the age group twenty one tirough twenty five vas a colored male spastic paralytic. The great majority of patients were bedfast and had lived in the home between one and five years. About nine percent of the patients had been there over ten years. The inmate with the longest stay in the Home had entered in 1904. How aged sixty two, she was mentally deficient (moron), crippled, blind, and had hemorrholds. Another patient had entered the Home in 1909 with the diagnos is of mental deficiency. Elghty seven patients were permanent residents, 17 were temorary. Only four reauired domiciliary of custodial care, and 20 nursing, while 80 required medical and nursing are combined. Tables 37, 38, 39 and 40 shows the above data. Tables 41 and 42 are based on material derived from the survey in Novamber, 1945 which brought the early study up to date and secured additional information. 


\section{TABLE 37}

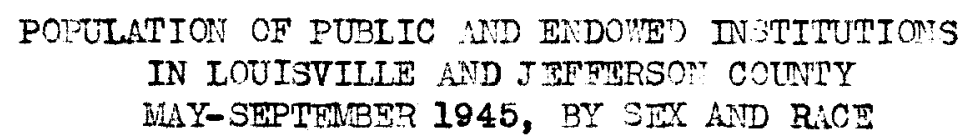

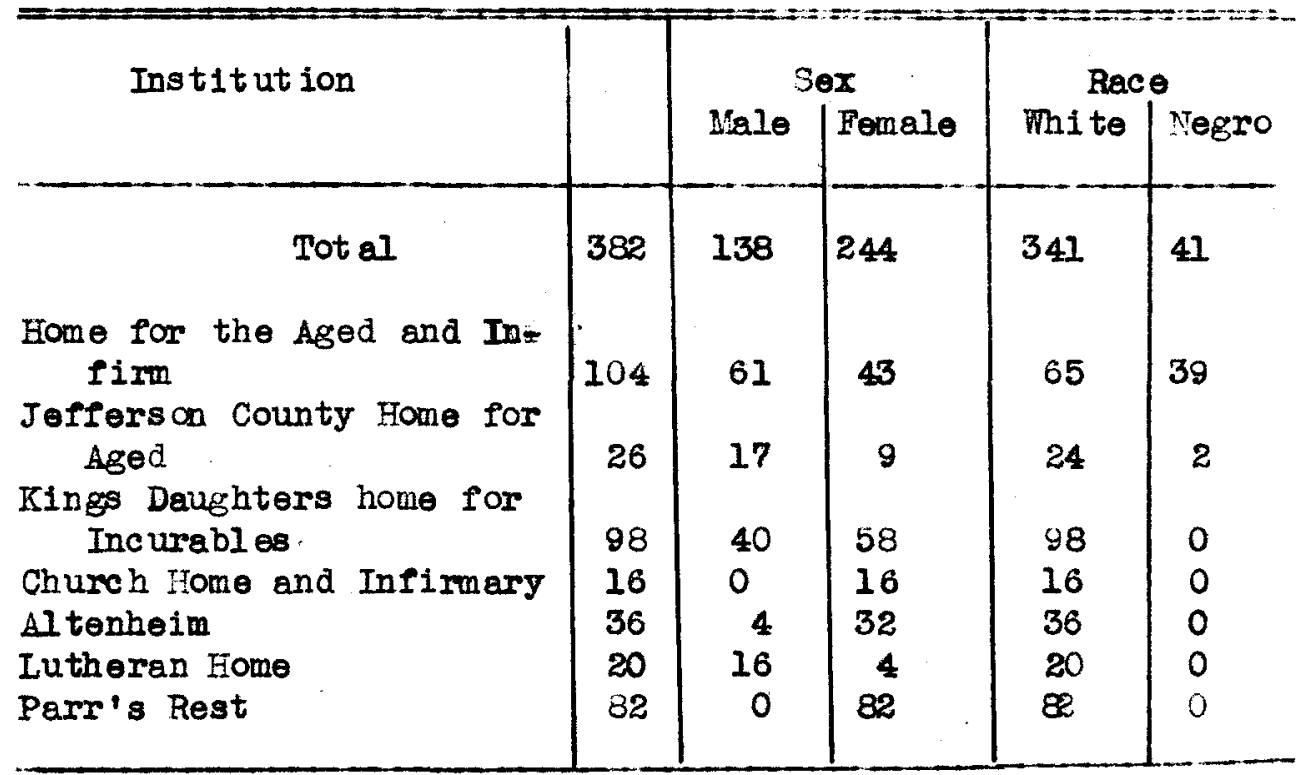

\section{TABLE 38}

POPULATION OF PUBLIC AND ENDOTED INSTITUTICNS

IN IOUISVILIE AND JTERERSON COUNTY

MAY-SEPTEIRER 1945, BY DURATICN OF STAY

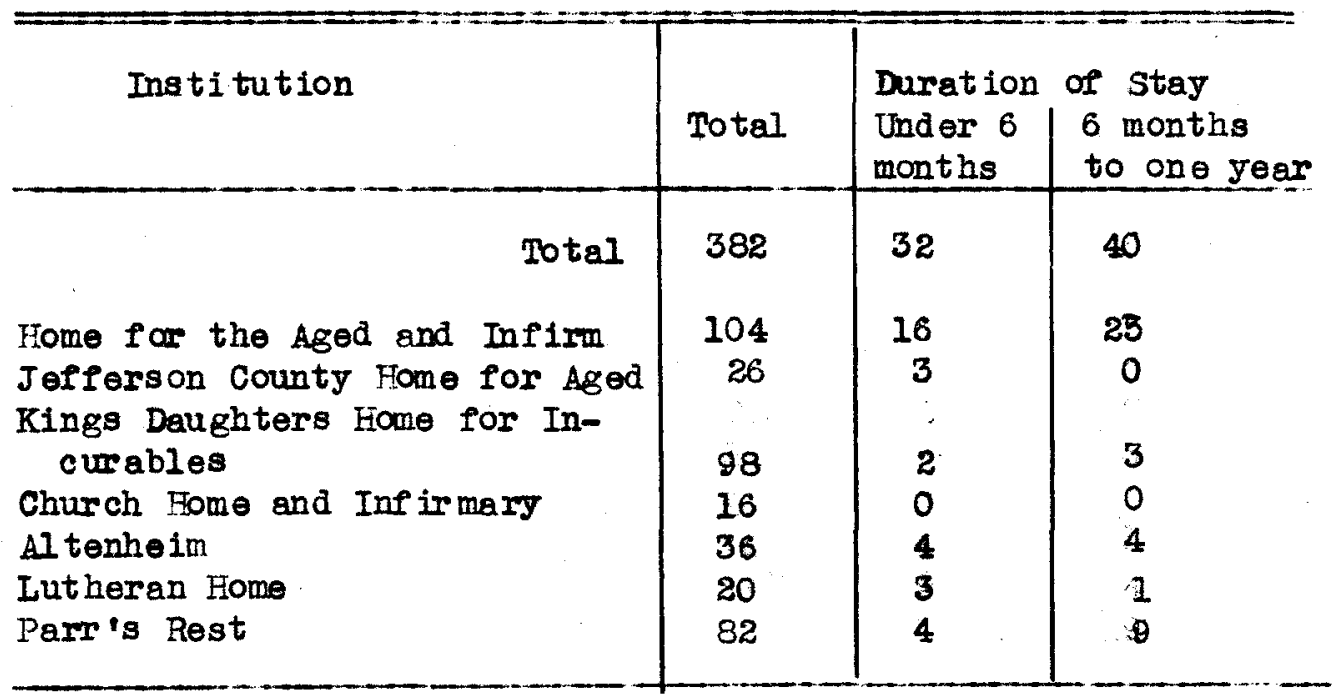


TARL 38-Continued

\begin{tabular}{c|c|c}
\hline $\begin{array}{c}\text { Duration of } \\
\text { one year to } \\
\text { five years }\end{array}$ & $\begin{array}{c}\text { five years to } \\
\text { ten years }\end{array}$ & $\begin{array}{c}\text { ten years } \\
\text { and over }\end{array}$ \\
\hline 146 & 81 & 83 \\
45 & & \\
9 & 11 & 9 \\
41 & 7 & 7 \\
8 & & 32 \\
14 & 20 & 7 \\
6 & 7 & 7 \\
23 & 4 & 15 \\
\hline
\end{tabular}


POPULATION OF PUELIC AND ENDO TED INSTITUTIONS IN LOUISVILIE AND JEFFEXSON COUNTY MAY-S STPENBRR 1945, BY DIAGNOSIS

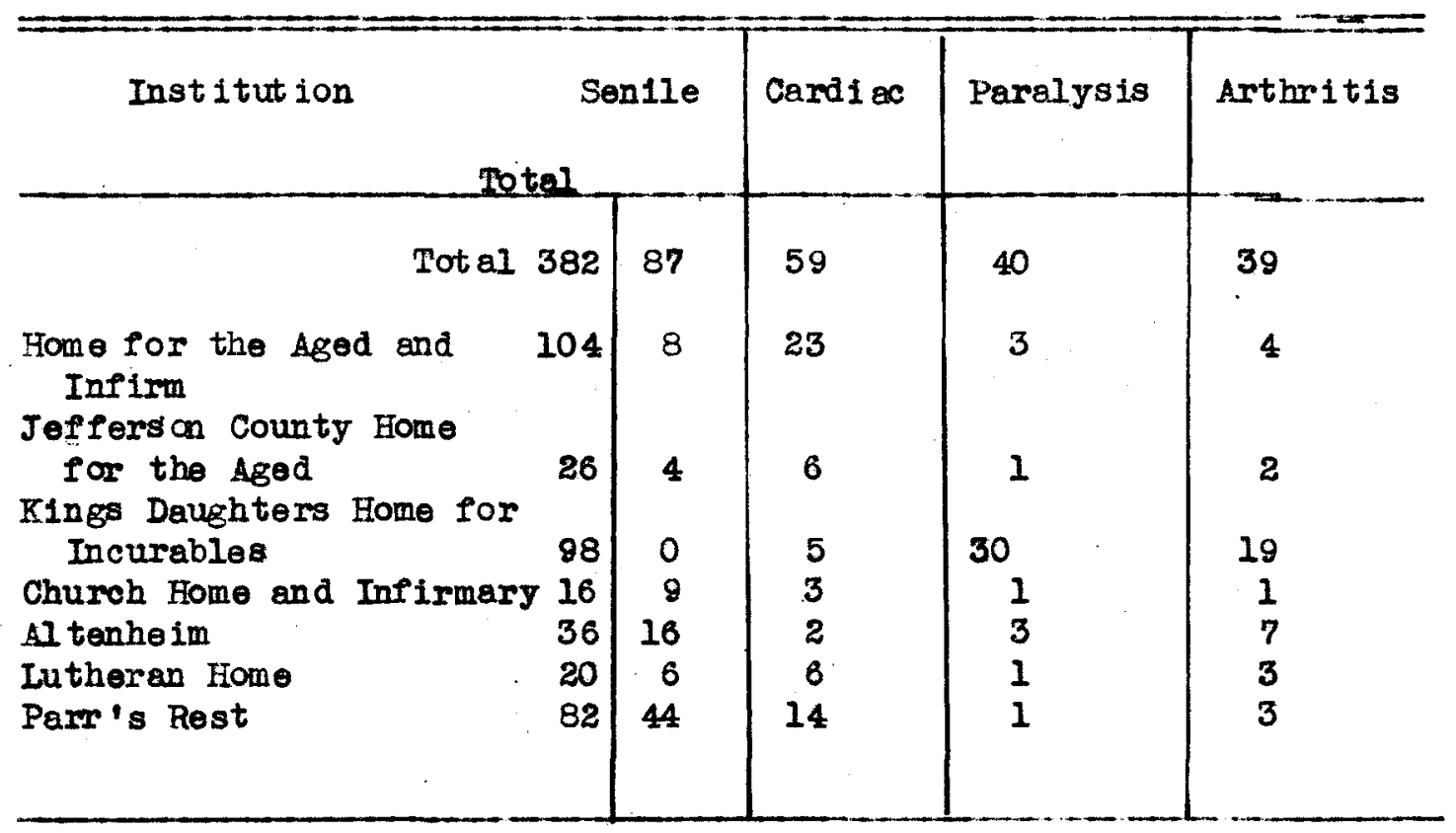


TABLE 39--Continued

\begin{tabular}{l|l|l|l|l|l|l|}
\hline $\begin{array}{l}\text { Frect- } \\
\text { ure }\end{array}$ & $\begin{array}{l}\text { Can- } \\
\text { cer }\end{array}$ & Luetic & Mental & $\begin{array}{l}\text { Cerebral } \\
\text { Accident }\end{array}$ & $\begin{array}{l}\text { Oateomyeli- } \\
\text { tis } \\
\text { litis }\end{array}$ \\
29 & 9 & 9 & 8 & 8 & 8 & 7 \\
21 & 3 & 8 & 2 & 8 & 1 & 0 \\
& & & & & & \\
0 & 2 & 0 & 2 & 0 & 0 & 0 \\
4 & 0 & 1 & 0 & 0 & 7 & 2 \\
0 & 0 & 0 & 0 & 0 & 0 & 0 \\
1 & 0 & 0 & 2 & 0 & 0 & 0 \\
0 & 0 & 0 & 0 & 0 & 0 & 0 \\
3 & 4 & 0 & 2 & 0 & 0 & \\
\hline
\end{tabular}


TABLE 39--Continued

\begin{tabular}{l|l|l|l|l|l}
\hline \multicolumn{1}{l}{$\begin{array}{l}\text { Diagnosis, Cont. } \\
\text { Amu- } \\
\text { tation }\end{array}$} & Blind & Anemia & $\begin{array}{c}\text { T. . of } \\
\text { bone }\end{array}$ & Diabetes & Other \\
\hline 6 & 5 & 4 & 2 & 1 & 61 \\
5 & 0 & 2 & 0 & 0 & 16 \\
& & & & & \\
0 & 2 & 0 & 2 & 0 & 7 \\
1 & 0 & 2 & 0 & 0 & 20 \\
0 & 1 & 0 & 0 & 0 & 1 \\
0 & 0 & 0 & 0 & 0 & 4 \\
0 & 0 & 0 & 0 & 0 & 4 \\
0 & 2 & 0 & 0 & 0 & 9 \\
\hline
\end{tabular}


POPULATION OF PUBLIC AND ENDOHED INSTITUTIONS IN LOUISVILLE AND JEFFERSON COUNTY MAY-SEPTEMBER 1945, BY CONDITION

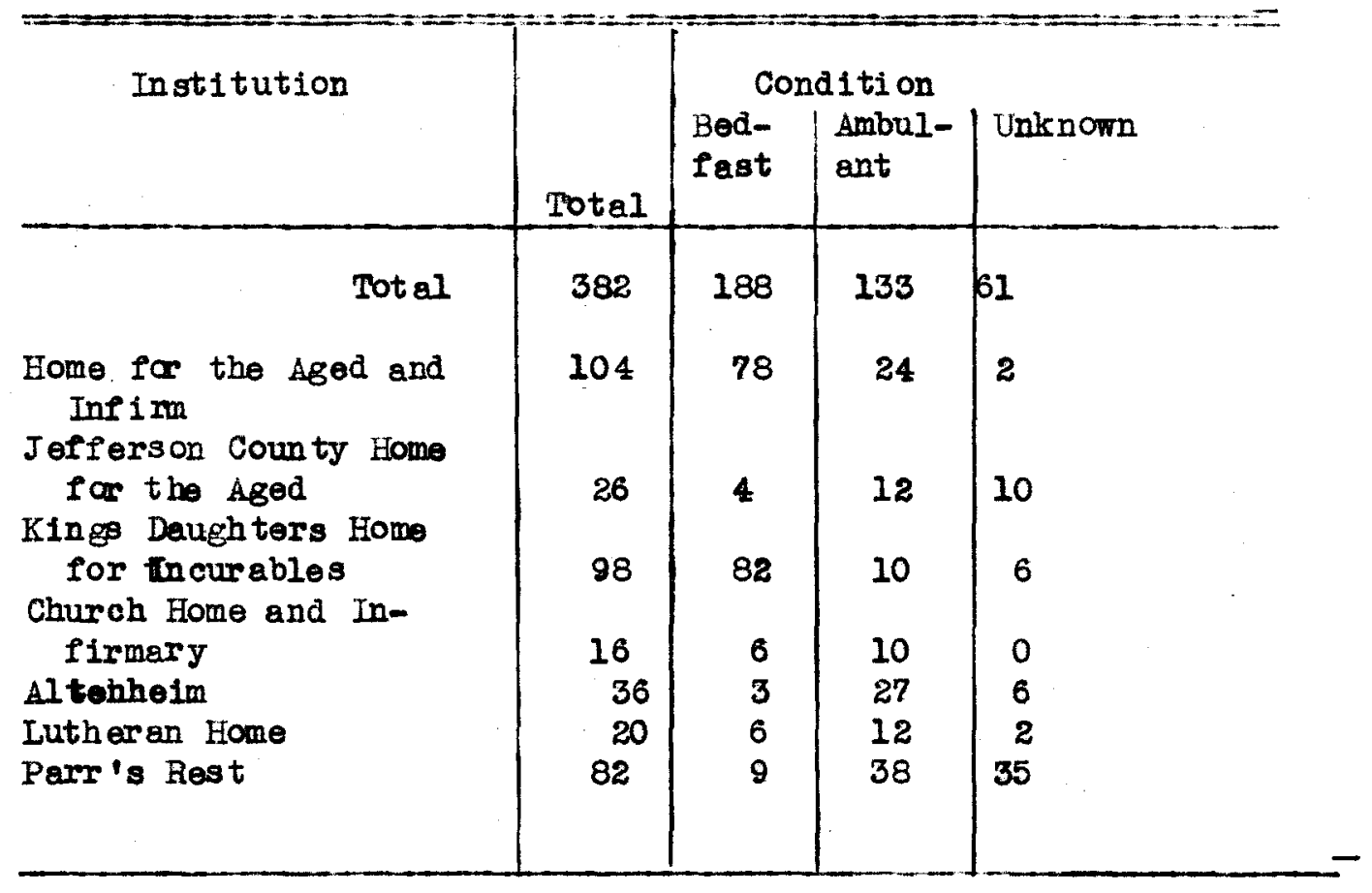

The Home for the Aged and Infirm provides about 105 hospital bods for 111 inmates. Modical care is secured through a physician, a supervis ory graduate nurse, two interns, and 13 practical nurses. Trenty bede are set aside far the use of patients referred by Louisville Caneral Hospital. This agreement was drawn up in 1931 botween the Depertment of Health, the Dean of the school of Hedicine, the Director of Welfare, and the superintendent of the Fome for the Aged and Infirm. 1 These beda are primarily intended $f \alpha$ use by convalescing patients, the purpose of the plen being to relleve congestion at General Hospital, but actually there is no separation of convalescent and chronic patients and in the main these beds are 
POPULATION OF PUBLIC AND IMDOHED TNSTITUTIONS IN LOTISVILLE AND JWTPERSON COUNTY NOVWMPBR 1945, BY TVPF OF $C \backsim R$ RECETVED AND RESIDENT STATUSA

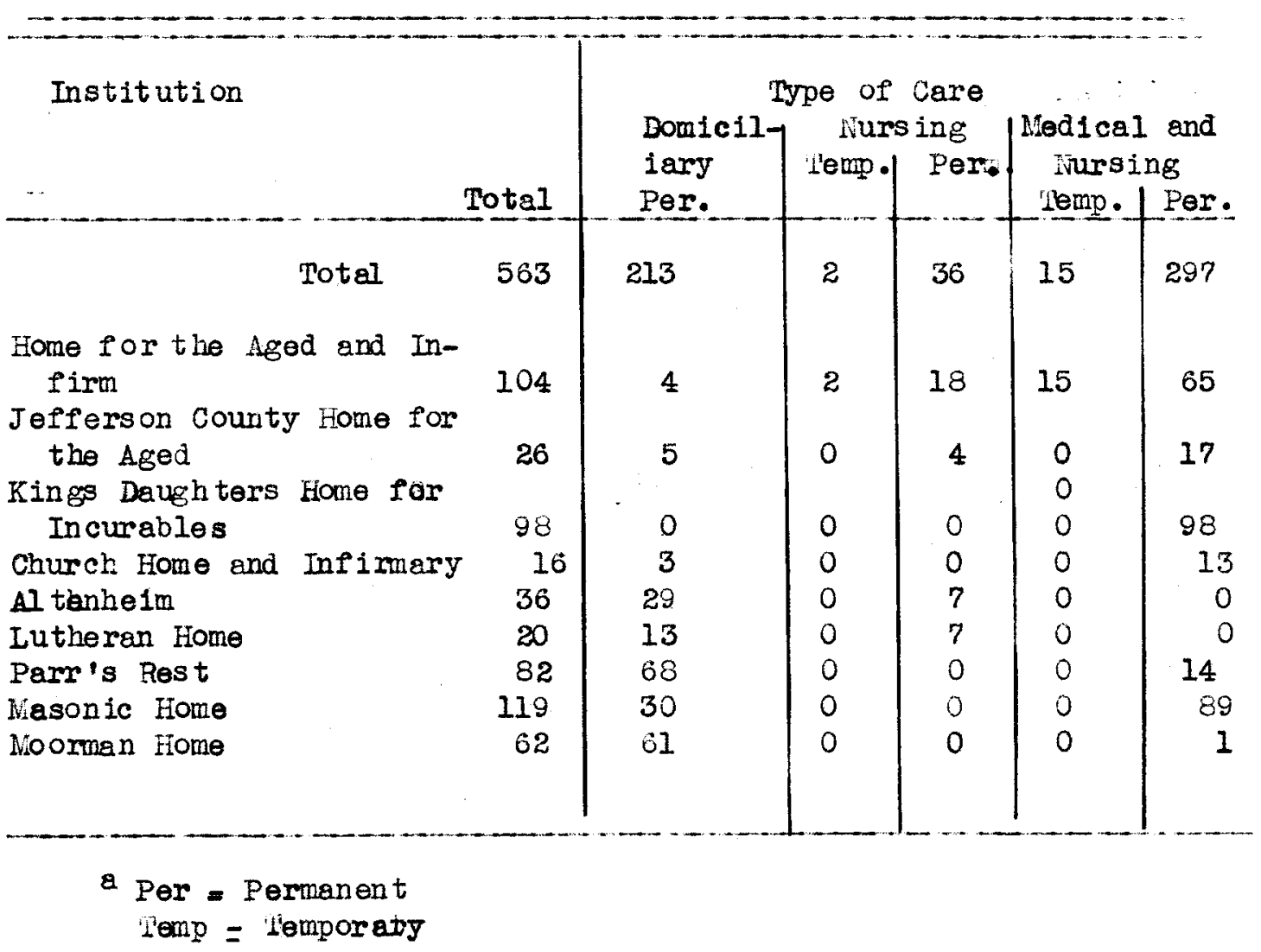


TABLE 42

POPULATIOS OF DUPLIC ND ENDO ED INSTITUTTONS IN LOUISVIIIE AND TEFETRSON COUNTY NOVWMER, 1945, BY ITPPORT

\begin{tabular}{|c|c|c|c|}
\hline Institution & Total & $\begin{array}{r}\text { Sup } \\
\text { Private }\end{array}$ & $\begin{array}{l}\text { port } \\
\text { Public } \\
\text { Assistance }\end{array}$ \\
\hline Tot al & 563 & 429 & 134 \\
\hline $\begin{array}{l}\text { Home for the Aged and Inf im } \\
\text { Jefferson County Home for the }\end{array}$ & 104 & 0 & 104 \\
\hline $\begin{array}{l}\text { Aged } \\
\text { King Daughters Home for In- } \\
\text { curables }\end{array}$ & 98 & 95 & 25 \\
\hline Church Home and Infirmary & 16 & 16 & 0 \\
\hline Althenheim & 36 & 34 & 2 \\
\hline Iutheran Elome & 20 & 20 & 0 \\
\hline Perr's Rest & 82 & 82 & 0 \\
\hline Masonic Home & 119 & 119 & 0 \\
\hline Moorman Home & 62 & 62 & 0 \\
\hline
\end{tabular}

a $_{\text {Supported by tine institution }}$

used for chronic patients. The plan has not resulted in the Immediate removal of many convalescent and chronic patients from Louisville ceneral Hospital because the re are few vacancies at the Home and patients remain at General Hospital for long Deriods of time until they can be admitted to the Home. A great amount of additional expense is incurred by this procedure, because per diem cost at the Fome for the Aged and Infirm is approximately $\$ 1.25$ as compared with $\$ 4.68$ at Louisville Ceneral Ho spital.

A trend towerds conversion of homes for the aged and almshouses into chronic hospitals has been in evidence throughout the country during the past decade. Passage of the social security Act oriding grents for the aged is believed to have been the 
precipitating factor, as many people upon establishing eligibility for Old Age Assistance (abso Aid to the Neody Blind) lert the institutions. "It is not known whether this move away from institutions reflected:

1. the possibility of the recipients living upon his payment.

2. that the payment was sufficient supplement to other resourses to permit maintenence out side an institution.

3. disatisfaction wi th institutional 1 ife.1

The matching of assistance grants to inmates of public institutions is prohibited by the Social Security Act. In some cases the departure of the aged resulted in pressure to abolish the almshouse, based on the theory that all of the inmates would be transferred to Old Age Assistance and the almshouse pepulation would be entirely depleted. The orer increasing number of chronically 111 was not reckone with. Instead, when the almshouses were emptied of their able bodied who were eligible for old Age Assistance, the chronically ill were left behind. The proportion of chronics in almshouses has steadily increased.

There has been considerable thought given to conversion of the Home for the Aged and Infirm in Louistile into a chronic hospital. Mr. Charles J. Rieger, Jr, past Director of Welfare is quoted as saying in his 1939-1940 annual, report: "I an confident that in the near future the Fome for the Aged and Infirm will become a chronic hospital for the aged. Out nlanning must cọtinue to be directed toward this development which perhaps will have to be tied in with

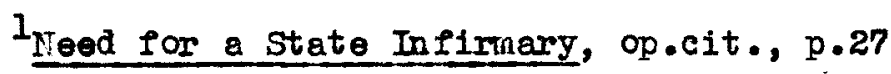


a general chronic hospltal. The need of such en institution has el ready been cited in detail by persons in close touch with the situation". I study of the Home for the Aged and Infirm, one purpose of which was to determine the feasibility of conterston, reached the following conclusion: standards in the fome compared favarably with the standards set up by the Joint Committee of the American Ito spitel Association and the American Fublic Velfare Association with a few exceptions, and that such conversion would be feasible if the following improvements' were made: an elevator instelled, better fire escapes, physiotherapy instituted, additionel wheel chairs secured, additional bathing and tollet fac1lities installed, the hiring of a dietician and at least one more social worker, a number of practicel nurses secured, and a program of Occupational Therapy started.2

The installation of elevator has been requeated by the department of Welfare (which operates the Home for the Aged and Infirm) for a number of yoars, to no avail. It has been estimated that about 30 additional patients could be cared for on the second floor if there were an elevator. The cost of the elevator and of its installation, also the cost of the additional beds is figured at about $\$ 8000$.

Capital Outlay Expense for Accommodations for 30 Additional Chronic Iospital Patients Jome for the Aged and Infirm. April 11, 19453

I. Installation of key-operated, self-leveling aut omatic elevator first to third floors. Hevator equipment proper 5 feet wide by 6 feet 6 . Inches front to back, by 7 feet high. (In-

IIIpets, I., op.cit., p.108.

2 In1d...,

3 Information sedured from Miss Louise Diecks, Director of Welfare, Louisville, Ky. 
cluding cantrol mach inery, car, rails, etc) 3,500

CCar gate

250

Outside doors

700

Labor on installation

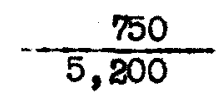

Labor on bullding shafts

500

Motor

$\$ 5,950$

2. Hospital equipment and supplies

30 hospital beds 25.20 each

30 mattresses 7.60 each

30 bedside table 9.75 each

15 bed pans 2.00 each

sheets, p1llow cases, pillows, spreads dishes

30 trays 2.00 each

1 rood carrier

1 dressing cart

1 whe el stretcher

2 laundry hanpers 17.75 each

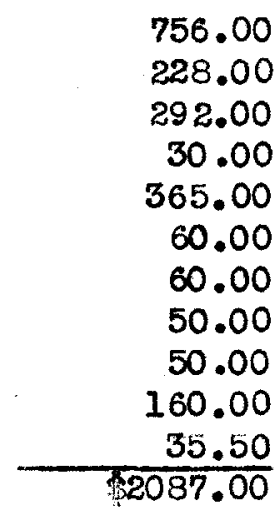

Total Capital outlay

$\$ 8037$

Not all of the opinion is in favor of conversion of the almshouse into a chronic hospital. The physical plant is often in such poor condition that it does not seem justifiable to expend the large sum that would be necessary to make the change. The bulldings are usually old and in need of expensive repairs, and nthe care given the patient corresponds with the character of the physical plant. 1 Class A and Class B patients should be cared for in a modern chronic di sease hospital and not in a converted almshouse. Class $C$ patients could receive suitable care in a

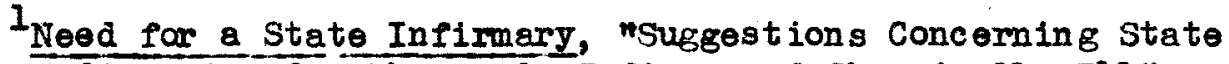
Infirmaries for the Aged, Infirm, and Chronically Ill", op. cit., $\mathrm{p} .6$
} 
home for the aged if facilities are provided in addition to thase which now exist. Other reasons why converted almshouses rarely moke satisfactory hospitals are:

1. Tradition surrounding the almshouso

2. Its place in the policital scheme of things

3. Its geogrephical isolation

4. Its reputation as a pauper asylum

5. Its antiquated bulldings and small size.1

There is also an important financial consideration, aside from tho actual cast of conversion. Chronic hospitals are, of course, in the institutional category, and patients in those hospitals would IOse their al igibility for the social security benefits, old Age Assistance, Ald to the Needy Blind, and Ald to Dependent Children, because the states would discontinue these programs, having lost the federel governments matching funds. Section 205.020 of the Kentucky Rerised Statutes reads: nold Age Assistance shall be grented to any needy person who is not at the time of receiving Old Age Assistance an inmate of any public or private institution except for temporary medical or surgical care in a hospital." This would mean that the local community would bear the entire cost of chronic hospitalization itself.

A special joint subcommittee of the Welfare Policy Committee and the ifedical Care Committee of the American Public Welfare Assoclation undertook to study this problem in 1945 in relation to tho granting of public assistance to inmates of public institutions

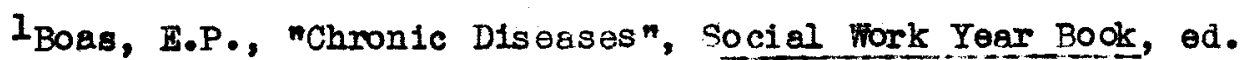
F.S. Hall, Russell Bage Foundation, New, York, $1933 ; \mathrm{p} .80$. 
(excluding patients of correctional or mental instutions and general hospitals). The subcomittee reported that the local governments in mast states bear almost the whole cost of hospital care for the chronically ill, a practice that would be increased should almshouses be converted in to chronic hospitals. The local units of government (usually the county) bear a share of the cost of institutional care, public assistance, and health and welfare services entirely disproportionate to the size of their incomes. 1

PABLF 43

DISTRIBUTION OF COST OF INSTITUTIONAL CARE, PUBLIC ASSTSTANCB, AND HEALTH AND WELARE SHRVICES BY LOCAL, STATE, AND FEDERI, GOVTRNMENTS

\begin{tabular}{l|r|r|r}
\hline \multicolumn{1}{|c|}{ Service } & Local & Sit of Gor erment \\
& & & \\
\hline $\begin{array}{l}\text { Institutional care } \\
\text { (some states) }\end{array}$ & $90 \%$ & $10 \%$ & $1 \%$ \\
Public agsistance & $12.9 \%$ & $41.7 \%$ & $45.4 \%$ \\
$\begin{array}{l}\text { All health and wel fare } \\
\text { services (1940 in } 34 \\
\text { urban areas) }\end{array}$ & $29 \%$ & $120.7 \%$ & $68.6 \%$ \\
\hline
\end{tabular}

The total tax yield of the United States in 1944 was 43.6 b1llion dollars; the federel gorernment receiving $82 \%$, the stetes eight percent, and the local units of government ten percent. It is estimated that if the cost of chronic hospital care is to be borne entirely by the countries it would absorb more then one fourth

I Brans, Louis, "Providing Institutional Care for Repiplents of Public Assistancen, Public Helfare, vol.3. No.11, Hovember, 1945, p.252. 
of their total tax revenues. The subcomittee concludes that the county is the governmental unit least able to carry the cost, and that the federel provisions should be revised so that public assistance may be granted to inmates of public institutions. Other solutions that have been worked out in some instances have been the states sharing of the entire cost with the local units, (IIlinois in 1945 authorized Old Age Assistance and Aid to the Needy Blind grants to inmates of county institutions, financed entirely from state and local funds) and the leasing of a almshouses to private operators in order that inmates might become el1gible $f a$ public assistance grants.

To substantiate the recommendation that the federal government expand its public assistance progrem to include inmetes of public institutions, the subcomittee repudiates the idea that the public assistance rolls would be swelled by enormous numbers of institutIonal cases by stating that the total maximum number of persons who would become eligible would be less than two percent of the present number receiving Uld Age Assistance and Ald to the Needy Blind. Probably between 30,000 to 40,000 of persons now in institutions would be otherwise eligible and would cost the feateral government ten to twelve millions or less then two percent of present expenditure. The same percentage, about two percent present numbers would become eligible for Ald to bependent Children. ${ }^{1}$ JEFFERSON COUNTY HOHE TOK IHE AGED

The Jefferson County Home is the public institution wich serves residents of the county, as does Home for the Aged and In-

1 Ibid., pp.250-253. 
Iirm, the city. Admissions to the home are the through the Jefferson County Welfare Department. Theoretically, the institution was set up as a hane for the indigent aged and is not supposed to accomodate people needing medical or nursing care, but like the Home far the Aged and Infirm, a large proportion of its population suffers same form of chronic disease. It is estimeted that "practically all 26 of the population at some time during the month are needing medical care". 1

The population of the Home is small, averaging 26 at any given time. Seventeen of these in September, 1945 were male, nine Were fenale; 24 were White, two Negro. All of the residents were permanent. Only three patients had been in the home for less than one year,; the others having lived there from one to over ten years. Seventeen inmates required modical and nursing care, four nursing care only, and five domielliary or custodial care. Almost one fourth of the population had a cardiac condition. Three timas as many were ambulatory as were bearidden. Only one of the inmates hed a private source of income. The above data is shown in tables 37 through 42 .

There is no medical staff in the home and the Welfare Department pays $f \alpha r$ is its by a private outside physician. The institution is currently under study for the purpase of determining whether it should be placed under the direction of the Board of Health. It is currently under the supervision of the County Commissioners.

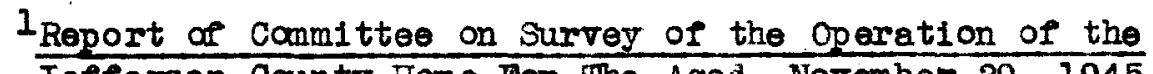
Jefferson County Home For The Aged, November 29, 1945. 


\section{BENSVOLDIT INSTITUTIONS}

The benerolent homs far the eged are end owed by church groups, fraternal orders, and others, and usually limit admission to people belonging to these various affiliations. A pretty mide spread practice is the guarantes of 11 fe care within the institution if the individual turns over all or part of his recources to the institution. Other institutions charge a rather high admission foe, and a larger one to people not affiliated with the organization sponsoring the institution, in return for which they too receive Ife care. A fow charge a monthly rate wich is lower than actual cost of care. Some institutions specify that the individual bo in good health upon admission, but they do take care of him if he becomes ill while in the home. Many have residence requirements.

Five benerolent institutions were surveyed in the above mentioned study by the Heal th Department, and in Novenber when the data was brought up to date, two more homes were added, as shown in tables 37 tmough 42. There are several additional institutions not covered by the study, including the cook Benevolent Institution, the Little Sisters of the Poor, the Secred Heart Home, Saint James Old Folks Home, and the Chris tian Church Fidows Home. The Church Home and Infirmary is non-sectarian. Cook Benevolent Home, non-sectarian has a five years residence requirement and specifies that the individual must have no relatives upon whom he can depend. If the individual has an insurance policy it is assigned to the institution for burial purposes. The Moorman Home has sifillar requirements. The mintmum age $f$ or entrance 
into the IIttie Sisters of the Poor which is al so non-sectarian, is sixty. It houses about 247 people, mostly men, and hes a 70 bed infirmary. The Loulgollie Protestant Altenheim has a minimum age of sixty five and a five years county residence requirement. Part of the individuals income must be tumed over to the Home. If there is no income a two thirds vote of the Board is required before the admission can be approred. The Masonic Home accepts widowg of Masons who are old and indigent. Parrs Rest is for Baptists and other protestants sixty years of age, ambulatary, with no income. St. James Old Folks Home is $f$ or Negro men and women, old and ind igent. Secred Heart Home is almost entirely limited to catholic women, al though non-catholics are admitted. There is no minimum age but applicants must be elderly, and have no chronic allment. They must be "respectable and deserving", and may pey boerd if they are able. The Christain Church Widows Home accepts people who are members of the Christian chruch far ten years and residents of Kentucky for five years. The Lutheran Home in Jefferscontown asks $\$ 500$ adnission charge and $\$ 1500$ of non-lutherans. Fifty eight years is the minimum age and residence of one year in mandatary.

Summarizing 8 ame of the above data, we see that senility was the major diagnceis for most of the patients in the nursing homes and benevolent institutions but heart disease wes more prevalent in the two city institutions; there were more ambulatory patients in nursing homes than in the public and endored institutions; in all three the residents were almost all permanent, and had an average duration of stay of from one to five years, although patients remained in public and endored institutions longer than the $y$ did 
in the nursing homes; there were more people requiring medic al and nursing care in the public institutions than in the end owed and nursing homes. Three eightto of people in all three kinds of institutions required custodial or domiciliary care, about one ninth medical care only, and almost one half medical and nursing care. Almost all of the institutional cases were supported by the institution (the Felfare Depertment in the two city homes), and elmcet all of the nursing home patients were paying the ir own way. There were many more femoles accommodated than males, and a preponderance of White over Negro. It was estimated thet there were 16 conveleswents in the nursing homes and 17 in the publ ic institutions. The studies also included $62 \mathrm{cr}$ onic patients known to be in their own homes and noeding chronic hospital care.

\section{LABLE 44}

CERONICALLY ILL PATIENTS IN EIDOWID AND

PUBLIC IVSIIUTIONS, PRIVATE NURSING HONES, AND

ONN HOMES, LOUISVILCE, KY. NOVEMBEP, 1945

\begin{tabular}{l|c|}
\hline & \multicolumn{1}{c}{ Total } \\
\hline & 860 \\
Patients in 7 endowed instutions & 433 \\
Patients in 2 public institutions & 130 \\
Patients in 19 private nursing homes & 235 \\
Patients in own homes. & 62 \\
\end{tabular}


HABLE 45

SUPPORT OF CERONICALIY IIL PATIENTS IN TNDOWTE VD

PUBLIC INSTITUTIONS, PRIVATE NURSING FOMES,

ANB IN OMN HOMAS, LOUISVIILE, KY., NOBEUBER, 1945

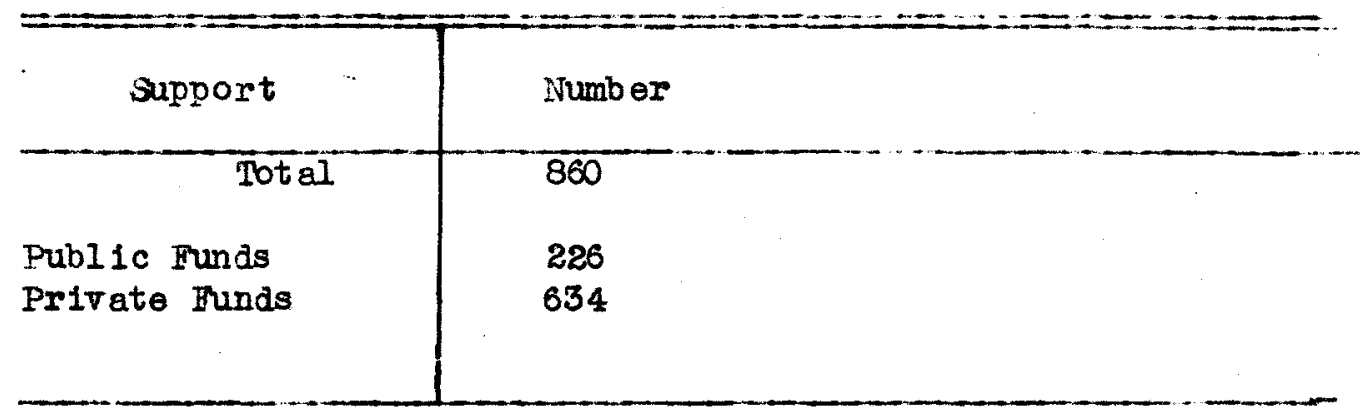

TABIE 46

TYPE OF CARE REQUIRED BY CFRONICAILY ILI

PATIENTS IN NDDO:E NDD PUBLIC

INSTITUTIONS, PRIVATE NURSING

HOMES, AND IN OWI HOME, LOUISVILLF, KY. NOVEMBIR, 1945

\begin{tabular}{l|r}
\hline Type of Care & Number \\
\hline & 860 \\
\hline & 331 \\
Domiciliary care & 91 \\
Nursing care & 438 \\
Medic al and Nursing care & \\
\end{tabular}




\section{HOSPITAIS}

Louisvilie's hospitals, voluntary as Well. as the General Hospital are taking care of the chronically 111 to greater or lesser degree. Some of these hospitals are:

\section{TARLE 47}

HOSPITHSS IN LOUISVILIE, KY. BY BED CAP ACITY

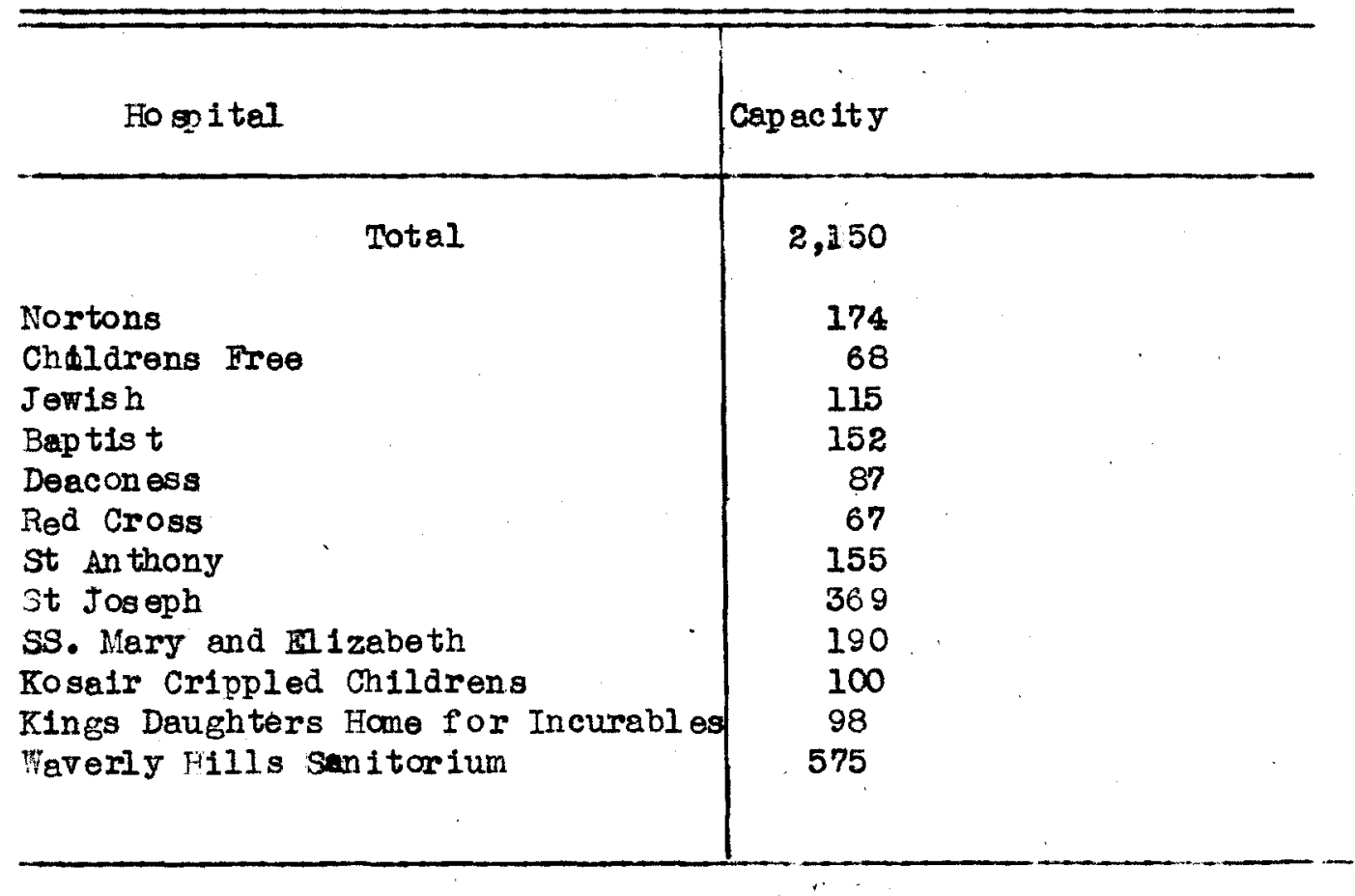

Planning for the mentally ill is not the responsibility of the munccipal government because the state has assumed this function. The report of the Committee for Kentucky states thet our mental haspitals are overcrowded, of ten with patients wo do not properly belong there and who constitute a "dead weight load", such as old age patients suffering cerebral arteriosclerosis. About one out of eight patients in our mental hospitals is not mentally ill, but is old, or pppled, or unable to care for himself. At least 3,000 
mentally deficient people in the state need institutionel care which is not arailable to them, the feeble minded institute having room for only 750.1

Several private santtoria are available far the treatment of the alcoholic, charging very high rates, such as the stokes Santorium.

The tuberculous are cared $f$ or in the 575 bed Taverly Hills Sanitorium. At a meeting of the Louisville and Jefferson Count $y$ Board of Health in March, 1946, a resolution was passed providing for sane liberalization of the admissions policy. Rules are now fexible enough so that the adnittance comittee composed of the Director of Health, the Controller and Assistance Controller, and the sociel investigetor of the Tuberculosis clinic, will have same discretion in hendling doubtful cases. KINGS DAUGUTERS YOTE FOR TNCURABLES

The KIngs Daughters Home for Incurables was included in the Heal th Department study of nursing homes and institutions caring for the chronically ill, but it is by actual definition, a hospltal. It is the only stitution in Louisville bearing the fearprovoking title "incurable". By estimate, more than one fourth of the population at Kings Daughters can be rehabilitated.2 In 1927 program of vocational rohabilitation was begun with the cooperation of the State Department of Education, which provided training in shoe repair and anto mechanics to a fer patients. The proposal in 1937 to convert the Home into a vocational guidance institution for handicapped young people has never been acted TCourier-J oumel (Loulsvilld November 18,1945 , section $3, \mathrm{pl}$, column 5 .

2Statement by Dr. John D. Trawick, isset.Director of. Health, Louisville and Jefferson County, Personal interview, February $12,1846$. 
upon.

The use of the term "incurable" is indicative of the fatalistic, defeatist thinking of so many about the chronic diseases. Starting with a bed capacity of about 40, the capacity of the Fome has more than doubled in the ensuing years. Patients are accepted from all over the state but an effort is made to keep the population in proportion to the Louisville population. The Home is atate and Community Chest supported and also derives part of its income from pay and part pay patients. Mentally ill, cancer, and tuberculous patients are not adnitted. Only White petients are admitted whose incapacity is of a permanent nature.

Family Service Orgenization has recently taken orer the function of investifsating new applicants; this being a temporary plan until a medical social warker can be secured. The Board of the Kings Daughters has the regponsibility for final decisions on admissions, and for all policies of the home. An attempt is mede to fill vacancies in the order in which applieations are made, but this is not always feasible as the next vacancy may, . for example, call far an ambulatory patient who may be far from the top of the waiting list. There are usually not more than 15 vacancies throughout the entire year. Family Service Crgenization is attempting to clear the waiting list of those people for whom other plans had in the meantime been made. ${ }^{1}$.

1 Taylor, E. op, cit. 


\section{CRIPPLED CTIIDREN}

The primary source of help for Kentucky's crippled children comes from the Kentucky Crippled Childrens Commisaton, a public agency receiving part of its money from the federal government under Section 512, Title V, as the amended sociel Security Act. State funds, in addition to the federal contribution, are supplemented by the Kentucky Society for Corippled Children, a private state-wide organization, the Kentucky chapter of the Netional Foundation far Infantile Paralysis, and from payments and donations. During the fiscal year July 1943 through July $1945,3,590$ Kentucky children were treated under the auspices of the Commiss10h. The average amount spent per patient was $\$ 185.59$ but this did not include the érvices contributed by many other comminity egencies including rallroeds; bus lines, and cab companies who gave passes and reduction in ticket rates, the county Health Depertment staffs, Travelers Aid Society, American Red Cross, and the local chapters of the Kentucky Society for Crippled Children. Saving is also effected through unif $\mathbf{r m}$ payment rates for hospitalization ich does not sppoximate the actual cost of such hospitalization.

The Commigsion provides free treatment for thite and Negro orthopedic cripples under the age of twenty one (this was an amendment to the original act which did not go past the age of eighteen, of sound mentality, whose parents are financially unable to pay for the child's treatment. Persons over twenty one years of age are referred to the Office of tocational Rehabilitation. Meny types of crippling conditions are represented in the Com- 
mission's patient load including: pollomyelitis, congenital defects, osteconyelitis, tuberculosis of the bone, injuries, spastic paralysis, eto. Functions include diagnosis, remedial care by hospitalization or appliance, preventive care, follow up, and referral to other agencies.

The Commission does not operate its own hospital but buys care far its patients at the existing hospitals. All applications for Kosair Crippled Childrens Hospital are cleared through the Commission. Kosair, in existence since 1926, is orned by the Kosair Charit ies Committee but is not one of the National Shrine Hospitals. It is operated by 1ts own Board of Governors. The Commission pays two thirds of the cost for each patient and the hospital raises the balance through its endowment thand and special fund raising activities. The hospitals original bed capacity has been increased from 50 to 100 beds. During the polionyelitis epidemic in 1944 the entire bed capacity was deroted to the treatment of polionyelitis cases.

Louisville Ceneral Hospital and St. Joseph's are also used by the Commission, the latter primerily for neurological cases. A physical therapy out-patient clinic is also located at Louisville ceneral, opened in Jenuary 1945 to provide follow up treatment far poliomyelitis patients of the 1944 epidemic. Occasionally a child is sent to Childrens Free Fospltal but this is mostly for medical care, and the commission does not pay for their treatment. 1

lKentucky Crippled children Lommission, Blennal Keport,1945. pp.4-24. Courier-Journel (Loui sville), November 11, 1945. Section 3, p.3, Column 1-4. 
It is estimated that there are some 2,500 to 3,000 cases of cerebral palsy (spastic paralysis) in the state of Kentucky (803 are known to the Commission) and surveys to determine the exact number are being cerriod on by the Louisville Lions Club and the Americ an Legion. Two bills are before congress providing for federal aid for spastics. The Pepper B1ll would distribute 75 million dollars to the states on a proportional matching basis. The other bill would increase the amount now provided under the Sociel Security Act for spastics by 50 million dollars. In April, 1946 the Kentucky Crippled Childrens Cormission and the Kentucky Society for Crippled Chlldren sent a committee to Baltimore and New York where a study of the facilities for treating spastic cases was being made, in an effort to learn how a special proFam involving modical treatment and educational training should be set up in the state. OTILDREN VITM REITUMTIC FEVER

Phaumatic fever is another serious chronic disease affecting, according to a study of Louisville Children attending public and parochial schools from 1936 to $1939,52 \%$ of school children. This figure includes both rheanatic heart injuries and heart injuries dating from birth. Rheumatic heart disease occurred in $33 \%$ of the White and $35 \%$ of the Negro pupils, and heart disease dating fran birth in $18 \%$ of the White and five percent of the Negroes. Louisville could secure money from the Federal Childrens Bureau (under Social Security provisions) for a program of care and treatment for rheumatic fever patients if it could establish eligibility through meeting the following requirements: by showIng a demonstrated need, by having an approved state agency to 
administer the program, and by having adequate facilitios where such care could be given. Louisville qualifies under the first two provisions, but does not have adequate hospitelization facilities. A program was prepared calling for an annual budget of 18,300 with which three centers could be established, one in Loulsvilie, for clinics and consultations under the joint direction of a heart specialist and a podiatricien. The plan is being held in readiness until such time when Louistille will become eligible for federal money to put it in to effect. Oklahoma had a rheumatic fever program approved in 1940 and there are now 18 states and the District of Columbia with approved programs. I Convalescent facilities for children with rheamatic fever are especially important. There are no such facilities in Louisville for Negro children except through the medium of foster homes. IOUISVIIIE GRNIRAL TOSPITAL

The Loulsville General Hospital has a bed capacity of 577 beds and 60 bassinets. The primary responsibility of the hospital is for the acutely ill patient but wi th much of its effort directed towards the chronically ill whose duration of stay is long and wo have frequent admissions, the hospitel is under great pressure is discharging the duty it owes to the acutely ill. The hospital has a public responsibility to care for the sick, but actually it is a moral obligation not enforceable by a court of law and General Hospital could therefore prohibit the admission of patients who were not in need of acute or emergency treatment if it chose to 
do so. Patients frequently "shop" for hospital care, and rejected by the private hospitals in the city, apply for admis sion to the public hospital. Louisville General Hospital has a liberal admissions policy and does not distinquish between the acute and the chronic if the individual appears to be in distress, althoueh the purpose of the Ceneral Hospital is usually conceived of as the care of the acutely ill in need of immediate medical diagnosis or treatment. Louisville General Hospital could take one of several courses of action: it could admit by the first oome, first serve" principle, thereby depriving many acutely ill patients of noeded haspitalization; it could take more than its quota of patients, thereby crowding the hospital and giving less service to the patients it accommodates; or it could refuse chronic patients not in need of emergeney treatment. It has chosen to compromise Fith emphasis upon the second plon, resulting in crowding and less service per patient. Some of the crowing is of course due to the nature of the hospital arganization itself. Medical beds may be in great demand one woek; surgical beds the next. One ward may be tremendously overcrowded, overflowing into the halls; another helf empty, but this cannot be altered as the hospitel is divided in to services.

Dr. Bachmeyer found that on an average day $15 \%$ of patients in the hospital are the obronically ill who need prolonged institutional care. The three weeks surrey in 1927 found about eight percent of patients who could be cared for in a chronic institution, and the one day survey in that year, $13.1 \%$ of total hospital popu- 
lation. The cost to the city of the care of the chronic patients in Louisville Generel Hospital for the year september 1925 through September 1926 at peralen cost of $\$ 3.16$ was $\$ 354,331.70^{1}$ Number of patient days . 112,153

Expenditures $\$ 35433.75$

Paid. by the Board of Sefety $\$ 314,331.75$

Contributed by mediaal school $\$ 40,000.00$ in services and money

The patients in the present study cost the city an average of \$84.24. The situation is not peculiar to Louisville General Ho spital. In New York City in 1928 one fifth of beds in general hospitals were occupied by patients with chronic disease. Nineteen percent of total facilities of Bellevue Hospital, the city's foremost general hospital, were given up to the care of chronic patients. It is estimeted that probably four percent of the ward beds of general hospitals may be oc cupied by chronic patients at any one time for a legitimate reason. 2 a survey in 1940 found that $27 \%$ of dismissed patients from Louisville General Hospital were readmitted within one month; 39\% from within two months to one year. Fifty two percent of all such patients were readmitted th the same diagnosis.

In 1944 the average length of stay per patient in a voluntary hospital in the United States was ten days. The camparable figure

1 Health and Family and Child Nelfare Council of the Community Chest, Study of the Provision for Chronic and Incurable Patients, Louisville, Ky., 1927.

2Jarrett, M.C., Chronic Illness in New York City. v01.1.p.51 
In New York City in 1940 was 12.3 days for voluntary hospltals and 15.8 days in municipal hospitals. Compared with total hospital days per pationt in a chronic hospital (133.2 days in a voluntery hospital and 172.9 in a municipel) it was estimated thet one chronic patient occupying a general hospital bed deprives 12 acutely ill patients of the use of that bed.l

The average length of stay per patient, in Louisville General Iospitel is twelve days, but we do not know what the average would be if chronic patients were not included in this figure. In the present study the average length of stay of previous admissions ras 5.8 days. This figure is low because it includes patients $f$ or whom the re were no previous admissions. Being a median averace, it also fails to take into account patients who spont as many as 204 previous days in the hospital.

Chronic patients remain in the hospital for long periods of time not only because of the nature of the ir condition and treatment given, but bocause it is particularly difficult to make discharge plans for them and they remain in the wards until satisfactory (under the circumstances) plans can be worked out, sometimes waiting for an expected vacancy in a nursing home, benevolent instituti on or the hospitel division of an Home for the sged and Infirm. During the month of January, 1945, about 41 patients (in-patients and outpatients) who required chronic care came to the attention of the

1 Rosenfield,I., op.cit., p.51-52 
In 1944 the average length of stay per patient in a roluntary hospital in the United States was ten days. The camparable figure in New York City in 1940 was 12.3 deys for voluntary hoppitals, and 15.8 days in municipal hospitals. Compared with total hospital days per patient in a chronic hospital (133.2 days in a voluntary hospltal and 172.9 in a municipal) it was estamated that one chronic patient occupying a general hospital bed donrives 12 acutely ill patients of the use of that bed.1

The average length of atay ner patient, in Louisville General Hospital is twelve days, but we do not know the average would be if chronic patients were not included in this figure. In the present study the average length of stay of previous admissions was 5.8 days. This $f$ igure is low because it includes patients $f$ or wh an there was no previous admission. Being a median average, it also fails to take in to account patients who spent as many as 204 previous days in the hospital.

Chronic petients remein in the hospital for long periods of time not mly because of the neture of their condition and treatment given, but because it is particularly difficult to make discharge plans for them and they remain in the wards until satisfactory (under the circumstances) plans can be worked out, sometimes, weiting for an expected vacancy in a nursing hone, benevolent institution or the hospital division of en Fome for the Agen and Infirm. During the month of Junary, 1945, about 41 patients (in-petients and outpatientst who required chronic cere came to the attention of the

\footnotetext{
${ }^{1}$ Rosenfield, I., op.cit., p.51-52
} 
socirl service depertment. Dr. Bachmejer notes that the voluntary non-profit hospitals in Louisville frequently are compelled to retain patients because more suitable facilities are not available..$^{1}$

\section{CERO-TS: FOSPITAIS}

A chronic hospital would seem to offer the best solution to the problem, not only as a means of saving money for the city, but more important because it would offer the chronic patient the most integrated plan of medical care. Patients suited to chronic hospital care are those whose homes are unsuitable, those who would not be receiving the proper modicel care at a nursing home, public or endored institution, those who are not eligible for cere at $a$ nursing home, public or endowed institution by reason of inadequate finances (or too adequate finances for the public institution) age, sex, color, residence, type of illness, etc., those who would otherWise be eligible but for whon no vacancy exists, and those for vihom no proper resource exists. In the 1927 chronic disease study it was pointed out that the city and county hames for the aged as well as the benevolent institution were not poviding adoquate medical and nursing service, that there was no provision for the care of cancer patients except in the hospitals for acute cases, that there Was no provision for crippled chiluren from 16-18 years of age nor for adult cripples, that there was no provision for colored chronic patients, and that rehabilitation service was inadequate; $50 \%$ of the chronic patients at Louisville General Hospital at the time of

\footnotetext{
$1_{\text {Bachmezer, A.C., op.cit. }}$
} 
that study were under 40 years of age, and over $75 \%$ were males, many of them fit candidates for a program or rehabilitation. Some of these defects have been remedied, but today, nearly twenty years later, many still exist. The institutions are still offering inadequate medical care, are careless about the diagnosis attached to the patients condition, are more crowded, the physical plants have become more rundown and neglected; but they have come to recognize the orerwhelming problem of chronic illness the they are faced with which may lead them to attempt to do something about it.

There is still no provision for cancer patients who usually require skilled nursing care, and would be proper candidates for a chronic disease hospital. Only one nursing home accepts them willing 1y, a few oancer patients are located in the two city and in one end owed institution.

The age for help to crippled children has been extended to age twenty one, following a Federel Childrens Bureau recommendation, and the program is adequate except for a few groups such as the spastics. Facilities are also lacking for rheumatic fover patients and no federal money can be gotten until such facilities are available.

There is a crying need $f(r$ planning resources $f$ or adutt cripples, the polio melitis victim, the arthritic, and the orthepedic cripple, among others, over the age of twenty one who are not eligible for the services under the Crippled Childrens Commission and wo do not $f$ it in to the Vocational Rehabilitation program by virtue of their unemployability. When their incapacity becomes 
great the only resource open to these patients is to seek admission to Louisvilie General ilospital, of ten ocupying a bed for months at a time. If they are discharged after a brief period, they of ten have to be readmitted within a short tim. A chronis hospital would be ideal for these patients, offering as long a period of hospitilization as is necessary for treatment and transfer to the custodial section of the hospital if the condition has becoke stationery and cannot be benifitted by medical and nursing care.

Negro chronic disease sufferers have little choice of facility. They can be admitted to the city institutions, or to the one benerolent institution for Negroes, or to three nursing homes, all of which had a 3C rating until November 1945. Negroes comprised $50 \%$ of chronic patients in this study but considerably less than $50 \%$ of resources are available to them. Convalescent care for Negro children is limited to whatever foster homes ari available.

Rehabilitation services were expanded with the vocational rehebilitation amendments in 1943 and are probably adequate to meet the need of those who qualify.

There has been considerable thaught given to buildine a chronic disease hospital in Louisville, as recomronded in the 1927 and 1937 community chest studies. The 1927 study recommended the such a hos pital be en extension of Louisville General Hospital as expert medical and nursing supervisi on is needed; that it provide pay, part pay, end free care; also that the existing institutions develop more adequate facilities; and that care in the patient's own home be cont inued whenever possible. ${ }^{1}$

${ }^{I_{\text {Study }}}$ of the Provisi on for Chronic and Incurable Patients, op.cit. 
The 1937 survey stated that such a hospital would: provide adequate medicel care for meny patients now suffering in their own homes; permit admission of more acute cases to Louisville General Hospital following the release of chronic disease patients; and reduce the per diem cost of care of chronic disease petients needing medical caro in an institution. It was estimated that a 555 bed hospital would be needed; 176 beds for the mentally abnormal "; 379 beds for modical, or thopedic, and tuberculosis cases. The inclusion of the mentally ill and the tuberculous in a chronic hospital is a proision open to much question. Nore adequate planning has been done for these two groups than for the medical, orthopedic, and surgical potients, and the latter groups would require a large hospital by themselves.

Dr. Bnerson in December, 1944 indicated that 20 chronic beds and 60 convalescent beds per 10,000 population is a fair estimate of need. According to this schedule, Louisville would need 760 chronic beds and 2160 convalescent beds.

The standard advanced by the Interdepartmental committee to coordinate Health and Welfare activities is 4.5 hospital beds per 1000 population but this is for generel hospitals, including chronic beds. In a Clevelend survey a conservative estimato was 3.3 beds per thousand population.

A preliminary report of a comittee on chronic and convales cent haspital care noted that there were 548 persons known to be needing medical or hospital care because of chronic illness in Louis-11le in January, 1945.1 In the report on the preliminary Lou isville

\footnotetext{
$I_{\text {Bachmezer, A.C., op.cit. }}$
} 
area hospital survey made in 1945 the author states; "certainly 400 chronic beds for the Louisville area would be a reasonable estimate of the needs of the community. nl public hoalth administrators in Louisville are of the opinion, however, that a much larger hoapital would be needed if the city is to begin to meet the needs of its chronically ill. One estimate is as high as $800-1000$ beds.

Dx. Bachmeyer stated in his report that at least 100 beds could be used for Class A care, but if patients whose disabilities are of permanent nature but who require medical and nursing care are included, several hundred additional beds would be needed. 2 Estimates of the size of the hospital therefore range anywhere from 400 to 1000 beds. Obviously, fur ther study is indicated befare any further planning can be done. No estimate is evailable from the above sources, of the number and proportion in each of the three categories; $A$, intensive medical care, $B$, skilled nursing care only, and $c$, custodial or attendant care, but in general it is believed that the re should be three custodial beds for every hospital bed. In lew York City in 1928 this division was as follows: over four fifths, c care, a very small number, B care, and one seventh, A care. At Montefiore Ho spital in 1927 the distribution was: $38 \%$ group $\mathrm{A}, 18 \%$ group $\mathrm{B}$, and $44 \%$ group $\mathrm{C}$. In the present study of Louisville Ceneral Hospital chronic patients, chronic hospital care was recommended for over one half; $50 \%$ of these were recommended for $\mathrm{i}$ care, only one patient for $B$ care, and almost half for C care.

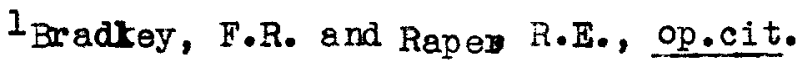

2Bachmeyer, A.C., op.cil.
} 
The most talked of plan for a chronic hospital is trre one that would involve converting Louisville General Faspitel into $a$ chronic hospital and building a new one for acutely ill patients, the scheme advanced by Dr. A. S. Bachmeyer who, at the request of the Louisville Area Development Association's Mospital Comittee, made a survey in February 1945 of the Ceneral Hospital, to develop future plans. Recommendations incluae the erection of a 600 bed hospital for the acutely ill and the conversion of at least two wings and the present nurses howe $f$ or the chronic patients. Convalsecent natients would have the use of at least one wing of the hospital and the present Psychopathic unit. Estimated cost of additional land, construction of new buildings, and conversion or remodeling of present buildings is five million dollars. Another plan is to build another wing adjointing the clinic building, to be used in addition to the clinic building for chronic patients. No plan has as yet been adranced, to our knowledge, to construct an entirely new building for a chronic hospital. Although it may not be applicable here, Boas" advice "The idea that buildings unsuited to the acute will provide satisfactory accomodations for the chronic sick, is wrong", ${ }^{l}$ should be heeded. It almost seems as though the chronically ill are being treated as step-children recelving hand-tro-downs from their older siblings. The new building, like the new dress, is being given the oldest and favorite child, although the younger child, chronically ill, will wear the eress for a longer time and actually should have the better one.

IBoss, E.P., "A Community Program for the care of the Chronic Sickn, reprinted from Hospttals, February, 1936. 
If a chronic hospital is build, existing facilities for caring for the chonically ill will not be discarded. The nursing homes and the city and benevolent institutions would still continue to satisfy the need of some patients more than a chronic hospital would. Bachmeyer states that the Home for the Aged and Infirm will continue to serve some of the chronically ill, as will nursing homes of proper standard. The important thing is thet the vardous levels of care be well coordinated, far mowever excellent the separate services if thoir effors are not coordinated, the individual falls into the gap and suffers. STANDARDS OF C RONIC HOSPITI CLAE

"The happy conception of a hospital with every modern appliance for the treatment of the chronic sick in a homelike atmosphere began to crystalize at the opening of this centuryn.2 Two principles of good chronic care are embodied here; first, that the hospital should have all of the facilities of the modem hospital for the treatment of disease, and second, that the chronic hospital should be planned to promote the corfort and happiness of the petient, especially because he will spend so much time here. Boas outhlines in some detail how a chronic hospital should be planned, from selecting a site to the amount of space alloted to whelchair storage. These specifications are intended, of course, for new construction, but certain of the principles may be adepted to a building already in existence. The highlights of Boas' plans are: 3

${ }^{1}$ Jarrett, H.C., Chronic Diseases in New York City, vol.1,p.49

$2_{\text {Bogs,E.P., The Unseon Plague Chronic Disease. }} .92$

${ }^{3}$ Ibid., pp.92-1,j 
1. Location in an outlying section of a city, beyond the turmoil of the city proper yet easily accessible by convient transportation routes.

2. Ample grounds, landscaped.

3. Five essential sections must be provided in the buildings: adminis tration, service, employees, medical, and custodial. In addition, a research unit and a nurses training school are highly desirable. Services are separated into nourological, general medic ine, surgical including orthopedic, and cancer; with corresnoiding wards.

4. Administrative unit should contain, among other things, a library, auditorium for religious services, general recreation room for moving pictures and concerts.

5. Pavilion type of construction to relieve elevators of wheelchair congestion. All doors, corridors, elevators, lavatories, recreation rooms, telephone booths, and porches large enough to permit free passage of wheelchairs.

6. Smal I wards or rooms with two to six beds in each. Ample room $f$ or personal possessions.

7. At least one sun porch on each floor.

8. Centrel dining room for custodial section(not practical for other patients) is economical and creates spirit of congenielity. Round tables 52 inches in diameter to accomodate four wheelchairs or six ambulatory.

9. Custodial unit close to the in hospital and connected with it by a corered pessageway.

10. Separate unit for children.

11. Tailor and barber shops and patients cooperative store.

12. Reception ward and examining rooms near ambulance entrince.

13. Dental service, physical therapy department, andorkshops of Occupational therapy department, within easy eeach of patients.

14. Follow up clinic for discharged patients.

The nature of Louisville General Hos pitals physical plant is such that it could meet many of the above standerds, if converted into a chronic hospital. It mould not meet the first standard, 
choice of site, of course, as it is located in the heart of the city. Al though not offering the advantages of ample grounds at minimum cost, this location does provide greater convenience of transportetion and saves the expense of constructing and maintaining employees quarters. The nurses building could easily be converted into the custodial section, and fits the above standards exactly as it is separated from, but within easy access of the main building. Whis leaves the problem of or oviding new quarters for the nurses, unless they could be housed with the nurses of the main hospital. The present emergency section could be used for recention and examining rooms (as they are now) and is located near the abulance entrance. Only four essential sections would be needed, as few employees would have to live in the hospital. The administrative section could remain where it is now, on the first and fifth floors. A more ample library than now exists, would have to be provided for patients. The medical library for the stafi could remain where it is, but the patients' own library should have more than just a 1 ew shelves for books; it should include an attractive reading room. A general recreation room is al so lacking under the present set up and an auditorium which might be located where the ampitheatre now stands. Sinoe the clinic bullding would no longer be in use for that purpose, except for a small follow up clinic, it could be used for tailor and barber shops and patients cooperative store, as well as for a recreation center. Louisville General Fospital does not have a parilion type of construction, being one large continuous unit; but its corridors are ample to accomodate whelchair traffic. The 
elevators in the main building are large enough to accomodete several wheelchairs at one time. Almost all the wards heve a closed sun porch, which due to crowding, is used as an extension of the werd; but in a chronic hospitel may be used as orieinally intended. Iderlly, there should be several open norches where the patients may have the advantage of fresh air and sunshine. General Fospital offers little opportunity for getting the patients out of doors. This is a serious lack. The wards as they are now constructed, are much too large and should be partitIoned of into six bed wards. Division into services rould, of course, be left to the medic al staff.

To meke the hospital as homelike as possible, and to relieve the monotony, it is important thet a variety of color be used. This would help to reduce the present drab appearance of the hospital. An example of this type of planning which has been put to good practicable use is the new hospital for chronic diseases on Welfare Island in New York. Bvery effort was made to make the interior of the buildings durable but also cheerful and colorfur. The wards are finished in peach tint, with the metal pertitions and radiators of a darker shate. Ward floors are gray and maroon, and the corridar floors blue and gray. Bxteriors of the buildings are greyish buff brick.

Chronic hospitels in general, have two goals: to give the best possible cere to those who need chronic care, and to return as many as possible to their homes. There should be proper sorting of patients, as the time to arrange for home care is before the patient becomes institutionelized. Patients accepted for chronic 
hospital care should be given a preliminary period of study before assignment is made to the appropriate section of the chronic disease hos pital. As has been mentioned, transfer from one section to another may be anticipated as the patients condition changes. The average length of stay at Nonetfiore Hospital in 1940 was six months. Hospitalization for chronics is a particulerly difficult problem becus se each patient $\propto$ cupies a bed $f$ or a long period of tine, and beceuse he can selaom pay for hospital care. In 1940 Nontefiore patients paid only $4.7 \%$ of the cost of care. (not including indirect costs such as interest on investments and depreciation of property and equipment). One partial solution to the former problem is a rehabilitation program. By training the patient to do useful work, he will in the future be less of a charge on the community. Such training also improves the patients morale and helps him to get better faster. Margolis suggests that patients be hospitalized for a preliminary neriod during which time the foundation for an entire course of treatment be laid. After he has made a start toward recovery, feels confidence in the program of treatment, and is given simple instructions, the patient is returned home where he continues care and treatment with the aid of relatives who have also been instructed, or a nurse.l This would often mork successfully, when the treatment is a form of phsiotherapy, when home conditions are suitable, when relatives can help, etc.

Patients pay little or nothing towards their care, but they

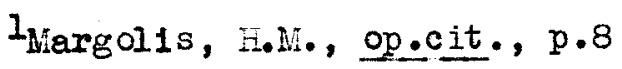


do not pay much more in an acute hospital either. (except in the voluntery hospitals). One argument almost always advanced in favor of a chronic hospital is that cast of caring for a chronic patient in a cronic hospital is much less expensive than the cost of maintaining this patient in a hospital for the acutely ill. The equipment in a chronic hospital is much the same, if not superior to that in an acute general hospital as it includes more elaborate physical and occupational therapy facilities; the dietary budget is higher as many patients require special diets; but the smaller turnover in a chronic hospital is one factor that reduces the cost. Personnel cost is also lower. in a chronic hospital. If custaifiol section is inclluded in chronfc hospital, the per capita cost is much lower than in a general hospital. The average per capita cat in Montefiore is \$4.14. Fifty seven percent ar this goes ffor wages and salaries; $22 \%$ for food supplies; seven percent for medical expenses; sever percent for plant maintenance and operation expenses. Montefiore estimates that the cost per day of maintainin a chronic patient in a hospital is about two thirds of the cost of maintaining an acutely ill person, but the period of stay is considerably longer for the chronic. The acute patient is more expensive to maintain in a hospital within a shorter period of tire, wille the chronic patient is more of a drain on the community, in the Ionf run, because of the prolonged character of his illness and the correspondingly reduced chances of any kind of return on his part for his care". 1

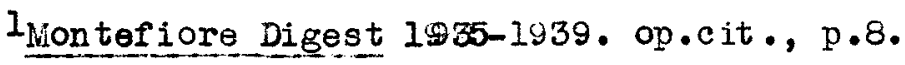


Since Montafiore lospital's standards are so excellent they should serve as a guide to what is desirable for public care. The 4.14 average per capita cost is probably higher than average cost elsewhere because so much research is done. Operating costs for other New York City municipal hospitals in 1940 were: ${ }^{1}$

general hospitals $\$ 5.19$

Goldwater Memorial Hœpital 2.93

(class A chronic disease hospital on Felfare Island)

Custodial chronic hospitals \$l.50

In 1943 custodial care in Monteflore Home in Clevel and, Ohio was \$2.33 per day. Distribution of cost was as follows:

$\begin{array}{lr}\text { Administration } & 10 \% \\ \text { Labor } & 27 \% \\ \text { Food } & 27 \% \\ \text { Medicel fees } & 2 \% \\ \text { Medical supplies } & 10 \% \\ \text { Nurses salary } & 5 \% \\ \text { Buildings end main- } & \\ \text { tainance }\end{array}$

Office, farm and other general expenses $20 \%$

The per cepita cost in Louisville's custodial institutions is cansiderable lomer but this probably reflects inadequate care given. The cost of chronic care the refore varies from 1.50 in a custodial institution to $\$ 4.00$ in a chronic hosoital offering custaial as well as medical and nursing care. The Tagner-

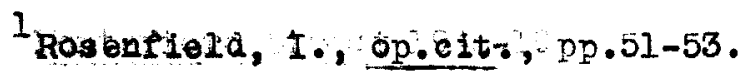


Murray-Dingall B1ll provides that payment for each day of hospitalization in a chronic institution shall be not less than 1.50 andnot more than $\$ 3.50$. The very much lower cost in a custodial insti tution as compared with a chronic hospital offering this care in combination with the two other types, $A$ and $B$, might be construed as a posible argument in favor of maintaining chronic patients in a custodial institution, but we know that these institutions are not equipped to give adequate medical care and that the burden would continue to be borne by the general acute hospitals.

Construction casts of chronic hospitals are estimated at anywhere between $\$ 1000$ and $\$ 7000$ ner bed, with operating costs depending upon whether the hospital is to house $A$ and $B$ pr custodial patients. The clronic disease unit of the Fairmont Fiospital in San Leandro, Celifornia was oxetod at a cost of \$1250 per bed.1 A 300 bed ward built at Wester State Hos pital, Washington for the aged mentally 111 cost $\$ 300,000$ or only $\$ 1000$ a bea. Dr. Peiser's estimate of the cost of constructing a state infirmary for Connecticut was $\$ 1000$ to $\$ 1200$ per bed. 3 A nerihospital wing added to the Home for the Aged and Infirn Hebrews in New York City cost $\$ 360,000$ or about $\$ 7000$ per bed; however this included an out patient department and extensive physical and occupational therapy facilities.4 The Goldwater Nemar ial Hospi-

IJensen, Andrew C., "Chronic Disease Patients, Housing them Smell Scale," Moderm Hospital, vol.54, No. 1, January 1940 $\mathrm{pp} \cdot 74-75$

$2 \operatorname{Cov} \theta$, George, "A constructive contribution to the comfort of the Agedn, reprinted from lioderm Hospital, Septenber, 1945

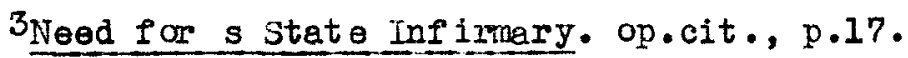

4 Butler, Charles, and Golub, J.J., Home for Aged and Infirm Hobrews. New Hoppital Wing" Hospitals, December, 1942. Np.49-54 
tal, a class A chronic hospital cost $\$ 4,630$ per bed to construct. The comparable cost of a grade B or grade C chronic diseases hospital is estimated to cost about $\$ 2,600$ per bed. The average construction cost per bed of an. acute general hospital including power plant, garage, nurses residence and training school, and out patient department is $\$ 8000.1$

NTRSING

The nursing staff in a hospital for the chronically ill may be, and usually is of two types; the greduate, registered nurse, and the practical nurse or attendant. Although the chronic hospital does not $r$ equire as many nurses as the general acute hospital, the quality of nursing care given must be the equal of that in the general hospital. Chronic patients $m$ be vary try ing, as they make a good many demands, end are general ly unpleasant to work with. The is little variety; the nurse sees the same patients week after week and month after month. In general, nurses dislike the chr anic service for the same reasons the doctors dislike it. The nurse in a clmonic hospital must have a $\varepsilon \infty 0$ deal of patience, tact, and firmness. They must be nintelligent observers- able to distinquish between real and fancied ills, trained in the psychology of the sick, anpreciate the value of and cooperate with the medical soial worker, occupation al therapist, librarian, daplain, in helping to maintain the patients morale, have an unlimited capacity for friendliness and kindness".2

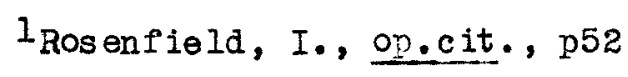

2Jensen. A.C., "Sufficient Nursing of cironic Illness", Modern Hospital, vol.63, No. I, July, 1944. pp.57-59 
The practical nurse is not equipped to give this type of service, and in the long run it is more expensive to have a majority of practical nurses; few graduate nurses. The chronic service should not be overlooked for the training of specialized, skilled nurses. It is estinated that two hours per patient per 24 hours of nursing are (including student nurses, attendents, and orderlies) is necessary for the satisfactory care of a patient in a chronic disease hospital, in comparison to thee to three and one nalf hours in a eeneral hospitel. 1 one nurse to every two or three natients in a general hospital; one nurse to three and one half patients in the hospital section of a chronic hoguital; and on nurse to $s i x$ and ons half patients (including graduate and student nurses, attendants, and orderlies) in tho custodial section of a chronic disease hospital is a desirable standard. 2

OCCUPATIONAL TEERAPY

Two of the "theraples" that are so necessary in chronic treatment are occupational therapy and physical therapy. Others. include radio therapy ( $x-$ ray and radium) and ps ychotherapy. Occupational the rapy is $\mathrm{m}$ important phase of treatment in a chronic disease hospital. "It may consist of any activity, mental ar physical, that relieves a natient temporary, or cantributes to

\footnotetext{
${ }^{1}$ Clay, Charles L., Mreeping Them Contented. Chronic Disease Petients," Modem Hos pital, vol.54, No. 1, Jantury, 1940. op.77-79.

2Jensen, A.C., "Effic ient Nursing of Chronic Iliness". pp.57-59
} 
recovery. The objectives sought are to arouse interest, courage, and confidence, to exercise mind and body in healthy activity, to overcome disability, and to re-establish, capacity for industrial and social usefulness. Like other forms of remedial treatment it should be prescribed and adninistered under medical advice and correlated with other treatment of the Patient".1 There is nothing quite so depressing to the patient as having to sit around idly, waiting for the next meal. Occupetional therapy in the form of simple crafts such as sewing, knitting, crocheting, weaving, woodwork, jewelry making, games and other group activities, give a tremendous boost to the patient's morale. None of the patients in this study were reported to be utilizing the service of the ccupetional therapist, and several of the patients, especially in the younger age groups, expressed a desire to occupy themselves in some way other than by looking at the ceiling, or conversing with the other natients.

PTYSICAL TIEPPY

Physical therapy, the treatment of disease by physical and mechanical means, has special application in the treatment of the chronic patient. It includes such forms as electro-therapy, hydrotherapy, thermo-therapy, helio-therapy, and mechanotherapy. Physical the rapy is ap 1 jed with the two fold purpose of preserving and strengthening bodily functions as well as counteracting the processes of disease. Tree conditions which in many cases can be especially benefitted by physical therapy are arthritis, cardio-rascular disease, and hemiplegia. In arthritis general

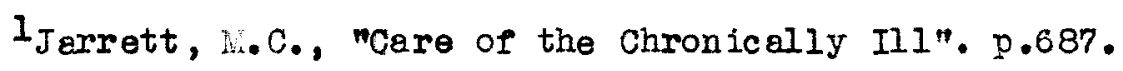


measures are used to increase circulation and metabolism. During the acute stages of the diserse, rest and applications of heat; dry, wet(contrast baths) or with diathermy, message, and the exercise of involved joints to prevent the formation of adhesions or atrophy of surrounding muscles is helpful.

The decompensated cardiac patient is helped by rest and message to improve the blood circulation. Clasely supervised postural exercise is helpful for the petientconfined to bed. Then nervous tensine exists baths and local heat may be given to advan tage.

The contribution of physical therapy to the hemiplegia patient, previously mentioned, consists of improving muscular coordination, strengthening of weak muscles and stretching of the stronger spastic ones, through mild heat, light setive message, and exercise, first mild then more active as muscular power returns.1 MEEICLI SOCII SBRTICE

The medical social worker has an important role in the chronic disease hospital. No plan of medical treatment is effective without c onsideration of the social problems that are inherent in each individuals situation. Every petient caning to the hospital is both a miedical problem and social being and planning for the individuel must take this in to account. A modical plan without considerat ion for the sociel factors; the frustration produced by enforced idleness, conflict between feel ings od depencience and independence, rearrangement of the ole life pattern, home conditions and family attitudes promoting or hindering the getting well process, has

IErickson, D.J. and Krusen, H'.J., op.cit., pp.80-92. 
little chance for being carried to a successful conclusion. The social plen must be a practicable application of the doctors recommendations to the patients soial situation. The social worker may have to halp the patient to accept the limitations imposed by the illness by finding the strengths within the individual and by making known certain community resourees. The petient may reject the illness, refuse medical care or accept. only those recommendations to his liking. At this point, the social worker, knowing what the medical implicationa are, helps the petient to see the need for medical treatment by showing acceptance of the patients feel ings and by encouraging him to express his conflicts. The skilled worker is able to distinquish real ity factors fron psychological; the $f$ amer consisting of such things as lack of knowleage of existing medical facilities, home responsibilities, inadequate finances, ete; the latter being deep rooted fears based upon feel ings of insecurity, fear of losing whatever satisfaction the illness holds, etc. The social worker's function then, is to evaluate the situation in the light of what a particular experience means to a particular individual. "Fach petient is unique in the problems he brings and the help he desiresn.1

To establish a helpful relationship with the patient, the social worker has to know what her ow feelings are. If she views cancer with dread, she may mever be able to face the reality of this diagnosis witi the patient; may never learn what meaning

${ }^{1}$ Cockerill, Heanor, "The social Worker Looks at Cencer", Family, vol.xvii, no. 10. February, 1937. p.327 
It has for the patient, with the result that the petient becomes more and more fearful and less able to take the steps necessary to getting well. With the arthritis patient this pent up feeling is expressed through painful immobilization of the joints; the joints getting the excess of feeling that should have been released through the medium of the social worker. "It is important that they have an opportunity to drain off this feeling for otherwise it can be as much a deterrent in the ir improvement as undrained round. nt

More and more, $s \propto i a l$ workers and doctors al ike are coming to recognize the effect of the enotions upon the petients physical condition, a phenomenon which has been given the name "psychosomatic medicine*. This relationship is especially apparent if we observe the patients adjustment to a prolonged disease. There are few people who can experience such a change in the ir life without some discomfort, some unhappiness, and some adjustment in the ir living pattern. Some people become tense and worried and withdrawn; they may be irritable and resentful. Bodily expression is given to these emotions in the $f$ orm of an exacerbation of their 1Ilness. It has also been shown that the etiology as well as the recurrence of the illness is conditioned by the individuals psychic make up. Every disease has its psychic as well as its somatic aspects. 'ihe social worker uses this concept by evaluating in each situation the degree of physical and the degree of emotional involvement, never putting so much stress on one as to exclude

1 Biddle, Comelia irowlridge, "The Individual in Relation to a kedical Care rrogram", Family, vol. XXV, No. 4, June, 1941 p. 110. 
the other.

'The petients problems are presented to the social worker in one of three ways: as a need for securing medical care, as problems of the erviroment, or as deen emotional problems. Often the first and secand are stressed by the patient, but it is in the area of emotions that the patient is real ly needing help. Sometimes the three are integrated as in the case of a patient who does not know the hospital and clinic set up and is assisted in getting to the doctor in the appropriate clinic and in stating her compleints to him. The worker y share her observations with the doctor based on the patient's behavior, and helps the doctor to achieve a satisfattory plan by discussing conditions in the home ich will directly affect the health of the patient. Carrying this example through furtiner, the patient may then be admitted to the ward and ile there tells the worker that she is worried about the children at home, about the family's inadequate income, about her need to have continued nursing care for a long period. The worker may then in the early stage of the disease, help the patient to achieve a mode of life that $w$ ill contribute to her eventual recovery by arranging for the petient to be admitted to a nursing hone, by arranging temporary foster home care for the children, and by helping the patient to file an application for Aid to Department Children to bacome effective en the patient returms to her own hame. All of this planning is done "with" and not "for" the patient, in response to her Eishes and neods. Soon afterwards the patient may begin to show signs of conflict over being in this dopendent position in the hospital. Everyone has a 
wish to be cared for, which is related to complete dependence upon parents in early childhood. This patient is experlencing the same thing in the hospital environment, with the doctor projected In the role of a rewarding or a punitive father (rewarding when he shows her special attention; punitive when he withholds her medicine or puts her on a liquid diet). As soon as the patient begins to improve she wgnts to leave the hospital; her core mature and natural feelings having returned to her. The doctor sagrs she is not reedy discharge, and she develops a sense of Irustration ove: the enforced idleness, a sense of gillt, believing herself responsible for her illness and conflict between wishes for dependence and independence. I The accial worker at this point by identifying with the patient, and riving her aceoptance, encourages the patient to release her feelings without increasing her feelings of guilt. She helps the patient to view the situation more ob jectively, point ing out the medical reasons why the patient must remin in the ward, and helping her to look forward hopefully to the day when she will be reestablished in her own home.

Medical social wark in a chronic hospital differs from that in a generel hospital in that cases may be more intensive and of much longer duration. It is estimeted that a ratio of one social to 500 admissions in a chronic disease hospital is necessary for adequate service. ${ }^{2}$

1 Gordon, Eckka, mreatment of Problems of Dependency Related to IIlness", Fam1ly, vo. XXIII, No. 6, June, 1943. p.211

2 Jarrett, M.C. "Care of the Chronically Ill". p.686. 


\section{PRIVINTIOIN}

The problem of prevention of chronic disease is mare a medical problem than a social or ecmomic but it includes such things as housing, sanitation, and recreation, which are the concern of the public health officers, social workers, publ is administrators, as well as doctors and everyone interested in maintaining and preserving the health of the community. There is no longer a clear cut distinction between prevention and cure; except for the saving in money and human suffering which Is effected when a disease is prevented and does not develop in to a full blown condition requiring treatment. All the health services of fered by the community are direct and indirect means of preventing chronic disease. Heal th education in the schools and follow up of children with health defects until correction is me, child heal th conferences, the Tuberculosis clinic., Nen tal: Hyglene clinic, Venereal Disease clinic, the six health centers, dental work with school children, compulsory health examinations for children of school age applying $f \sigma^{*}$ work permits, the educational work of the Health Department and public health nurses, the pasteurization of milk, the food handlers classes, the publicity put out by the Central Dairy Council, the immunfzation program, and the classes at Loulsti lle Coneral Fospital for expectant mothers, are just a few of the many services offered the community as a means of preventing chronic diseases. In 1944 the Heal th Department reported 11,560 complete physical exaninations done on school children, in $44.5 \%$ with parents present. Poor posture was the most cormon defect 
found, with poor teeth next. Seven thousand and fifteen school children had sonf form of dental work tone at the schools and in two of the health centers. The preventive clinic gave small pox vaccinations and other immunizations to 2.071 children as well as 1,746 complete examinations for milk handlers, civil service employees, etc. It was felt, however, that a great deal more could have been accomplished in these three areas, if it had not been for the shor tage of personel.1 In all of the preventive divisions of the Heal th Department (including Administrative, Communicable disease, Preventive medicine, Fealth centers and home care, Red Cross Hospital, Laboratory and Food and Sanitation) a total of $\$ 265,915.89$ was spent in $1944 .^{2}$ One hun ored thousand dollars, about $40 \%$ of this came from the federal gorernment. The Feal th Department is in danger of losing the federal contribution if Louisville gives up its civil service law, which is proposed. It is required that the funds be administered by the local units operating under the merit system.

Community education is probably the most productive method in the field of preventive medicine. The voluntary national health agencies are spending huge sums of money for research and education but a good deal of the effort and money is being used on the diseases which are relatively well under control, and are not so prevalent or disabling as others, which receive little attention. If cantrol of some of these chronic diseases such as diabetes and heart disease were ttacked with as much vigor as has characterized the $i$ ht against infantile paralysis and

$I_{\text {Louisville and Jefferson County Health Department, Annual }}$ Report 1944 pp.52-53.

${ }^{2}$ Toid., pp.110-111 
tuberculosis, "it should be possible to reduce the aiabetic death rate by $20 \%$ within the next five years", 1 and to do at least as well for cardiac conditions. "There are 100,000 free bed provided for tuberculosis patients in the United States and $100,000,000$, is spent annually to care for patients with this disease. Yet arthritis. hes only $\$ 200,000$ to cover research and treatment. Al though not communicable, it produces more irral ids than does tuberculosis. "the voluntary health agencies spend $\$ 4$ per case annually for poliomyelitis, \$22 for tuberculosis, $\$ 8$ per case of cancer, and only .05 per case for diabetes, and .03 fer heart di sease. Yet there are 660,000 cases of diabetes, $3,700,000$ cases of heart disease, and only 550,000 cases of cancer, 680,000 cases of tuberculosis, and 175,000 cases of crippled persons. A national hoelth fund is suggested as a means for overcoming these inequalit ies. ${ }^{3}$

Research to discover the causes of the chronic diseases, many of wich are unknown, is another important aspect of prevention. A good deal of this reseerch would be done right in the enrunic tosoital.. War from being an undesirable residue discarded by the mill of the generel hospital the long term petient is precious clinical material for the men of science. He is under control over comparatively long periods of time and deductions mede

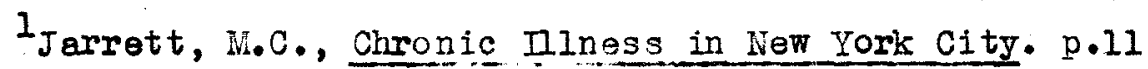

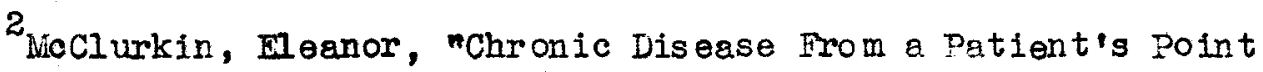
of viewn, Modem Hospital, vol. 65, No. 5, Notember, 1945. P. 79 .

${ }^{3}$ Buell, Bradley, "From Yestoday to tomorrow", Survey Midmonthly, rol. 1xxxi, No. 10, October, 1945, p.252. 
from the treatment of his condition are therefore more likely to be reliable."l

A three point program is advanced to encourage research in the chronic field:

1. Create adequetely neid positions for physicians in this branch of medicine.

2. Establish research funds and grents to enable physicians and medical soientists to pursue such work.

3. Create greater emphsis in the medical schools upon the chronic aspects of disease. 2

\section{FEDEAI PARTICIPATION}

Federal participation in programs of rehabilitation, services to crippled children, and public assistance as they effect the chronic ally ill, heve already been mentioned.

Federal programs of aid which would directly affect the health and welfare of the chronically ill and are in their planning stages include:

1. Exten sion to social security benefits to inc lude those living in institutions who would otherwise qualify for the public assistance programs.

2. Revision of the Old Age and Survivors features of the Social Security pragram to inc rease coverage and to include insur ance age inst wage loss through temporary or permenent disebility.

3. A program of federal grents in aid to the states to expend

${ }^{1}$ Bluest one, E.M., "Administrative Axioms", Modem Fospitel, vol. 65 , No. 5, November, 1945. p.77.

ENeed for a state Inf immary, op.cit., p.42. 
their existing hospitals or to provide new construction.

4. A nationel health program which would in reality be an extension of the Social security program.

The first and second plans have been discussed in the body of this paper. The program of aid for hospital expension was recommen ded as early as 1938 wen the Interdepartmental Committeo to Coordinate Health and Wel fare Activities met in washington. It was pointed out in a report by the rechnical Committee on Medical Care nThe long duration of the average case of chronic disease and the specialized requirements for dirgnosis and treatment combine to make illness of this type expensive to persons in low and dependent income groups. The assumption of such costs presents a serious burden without such aid from public funds as hes been rrovided for the treatment of the tuberculous and the mentelly diseased". 1 It was recomended that federal grants be computed on a basis of $\$ 300$ pe $r$ bed per annum for general and tuberculosis hospitals and 150 for mental institutions, not to exceed $50 \%$ of the actual patient day costs. The grant was to last only during the first years of the ir operation. ${ }^{2}$

A bill protiding for about three billion dollars of federal money to be spent on a hospital construction program is in congress now. The IIll-Burton Senate Bill 191 reads, "To amend the

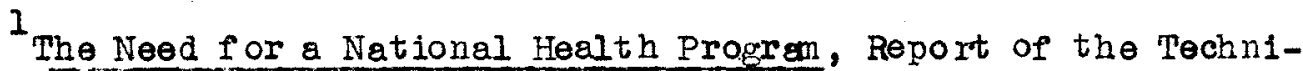
cal commit ter on ifedical care, Interdepartmental committee to Coordinate Health and Nelfare activities. Tash ington, D.C. JuIy, 1938.

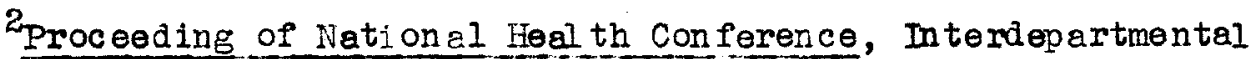
Committee to coordinate Health and Welfare activisies, Washington, D.C., July, 1938. p.47. 
Public Health Service Act to authorize grents to the states for surveying their hospital and public health centers and for planning constmaction of auditional facilities, and to authorize grants to assist in such construction". The aim of the bill is three fold, then:

1. To inventory existing facilities.

2. To develop prograns which $w$ ill insure the neceasary physical facilities for fronishing adequate hospital, clinic, and similar services to all of the people"

3. To aid, through federal grants, the construction of such physical facilities as mey be necessary to develon such a program.

The Surgeon General of the United States Public Health Service would administer the plan, with guidance from a federal advisory c ouncil. Payments would be made to the states after submission of an approved plan, but provisions are also made for direct payment to hospitals such as the private hospitals, if under the law the state is not authorized to make payments to these hospitals. The bill has, in general, received witde support from hospitals, health, and medical authorities, and has been endorsed by s me of the national health agencies. I If the measure goes through, it might well provide the assistance necessary to start a chronic disease hospltal in Louisville. There is some question, however, about whether Louisville would meet the standards set by the bill. The fact that Louisville has no licensing law for hospitals might

1

"The Hill-Burton Bill", American Journal of Public Health, vol. 35, No. 4, April, 1945. p.380. 
disqualify it for federal assistance. As though in anticipation of Louisville's not qual ifying for federal money, Dr. Bachmeyer "emphasi zed---thet local resources were sufficient in 1913 to build the Ceneral. Hospital and should be sufficient to provide the modern facilities so urgently needed now ${ }^{n}$ I The Wagner-Murray-Dingell Bill has been called "America's greatest health opportunity".l There are 235 prepaid medical care plans in operation in thirty eight states, covering an estimated six million persons. The Wagner-Hurray-Dingall bill would increase the scope of modical services to include almost every person in the United States. The bill plans "to provide for the national security, heal th, and public welfare" by expanding medical and research facilities to include ordinary medical care and hospitalization, by broadening public assistance to the aged, blind, dependent children and unemployebles, by expanding the coverage of the present Social Security low, and by increasing unemploynent peyments to cover temporary or permanent disability, retirement pay, and survivors benefits. ithe Surgeon General of the United States Public Health Service would administer the law. It is expected that the program would be financed through additional social security taxes, not te exceod $4 \%$ of earnings. Universal modical care through health insurance, provided for in this bill, is probably the most effective method at our command for combatting the chronic diseases.

$I_{\text {Louisville Area Development Ass } \propto \text { iation, Planning for }}$ the Louis ville area, No. 5, march, 1945.

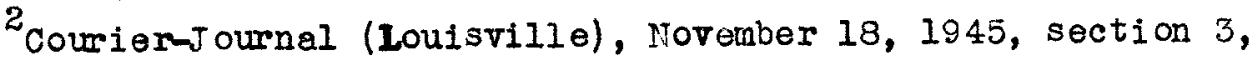
p. 2, colum 5-6. 
Before federal aid can be used to greatest advantage, indeed, befor a community can qualify for federal aid, it must have worked out a good program of its own. In the Louisville area it is suggested that the Council of Social Agencies lay the foundation by sponsor in studies and creating public interest, and in general acting as a coordinating body. The essentials of a good community program as advanced by hary $C$ Jarrett are:

1. Lo create public recognition that chronic disease constitute the next great field of public health work to be un dertaken.

2. ito break up the whole problem of chronic illness into its natural parts, that is, the problems peculiar to different forms of chronic disease requiring special measures $f$ or the ir prevention and treatment; and to differentiate the particular physical, mental, and social problens of child hood and youth, middle age, anci old age for each disease.

3. To outline a program for each division in then the type of disease and the age of the patients present special problems.

4. lo consider how available funds for research in to the causes and prevention of chronic physical disability may be allocated to obtain the greatest benefits to the health and welfare of the community.

5. To provide for the integration of mental heal th services with medical services in the study and treatment of chronic diseases.

6. To study the extent to wich social and economic factors contribute to clronic illness caused by different forms, of disease and the possiblitites of preventing disability through social services.

7. To demonstrate the feasibility and economy of various forms of care for different types of chronically ill persons.

8. To promote public responsibility for the care of the chronic sick.

9. To establish a municipal chronic hospital administered and equipped as a modern medicel institution with a custodial department for the permanently disabled whom hospital care can no longer benefit and wo cannot 
be cared for at hone.

10. To reconstrux the city homes for the aged and infirm.

11. To determine what policy the city should adopt in regard to home care for the chronically ill. Home care is more economical, and a much happler solution for many.

12. 'To determine the function of the Department of Health in a program for the control of chronic diseases.

13. To define the policies of the different types of private agency that assum responsibility for the care of the chronically ill and to formulate standards for the discharge of this responsibility.

14. To form a central planning committee equipped to attempt such an organization of the community's resources as has been suggested and to initiate the development of add1t on al facilities.1

A community with a high proportion of chronleally 1 ill has lost some of its vitelity and productiveness. The few must carry the burden of the many. A good part of its income must be spent in providing medical facilities and public ass istance for chronic disease sufferers, especially for those who become permanently disabled. The cost of chronic illness, direct and indirect, is high and is paid for by the individual, his faily, and the community.

${ }^{1}$ Jarrett, H.C., Chronic IlIness in New York C1ty. 
CONCLUSION AND RECONMENDATIONS 


\section{CONCLTSIONS AND RECOMRTDITIONS}

This study was attmepted as a statistical demonstration of the extent and nature chronic illness among patients of Louisville General Hospital admitted during an average ten day period.

I. Analysis of the case records yielded 76 cases of chronic illness, or one sixth of total patients admitted. More than one fourth of these were petients admitted to the psychiatric wards. Previous studies have shown a higher proportion of chronic illness among Louisville General Hospital patients.

2. The average chronic patient studied was male, white, 43.5 years of age, married, with no children at home. He lived with relatives in a household of 2.8 poople and paid 11.45 monthly rent 2.4 rooms. He did not pay anything towards his care in the hospital and had an income of $\$ 4.50$ a month, derived from earnings as en unskilled laborer.

3. The average patient had a heart disease of five to ten years duration with poor prognosis. He had spent 5.8 days in the hospital before the present admission. Including the present hospitalization he cost the city $\$ 84.24$ at $\$ 4.68$ per diem. In a chronic disease hospital his care would have cost anywere from $\$ 1.50$ to $\$ 4.00$ per diem, depending upon the kind of care he would be receiving.

4. Patients may receive either intensive modical care including mursing, or chiefly skilled nursing care, ar custodial-attendant care. The patients in the study were all receiving intensive medical eare and a large number had attended clinics prior to hospitalization and continued to do so after discharge. Two thirds of patients con-

tinued toreceive some form of supervised medical care after leaving the hospite 
5. One half of patients would need to continue to receive intensive medic al care in a hospital or clinic, one patient would require skilled nursing, the remainder needed custodial care in an instituticn or hospital end a fer in their own homes, according to doctor's recconmendations.

6. Chronic hospital care fas recommended for over one half of patients; less than half in the secti on of the hospital offering intensive medical care, a rery mall percentage in the section offering only skilled nursing, and orer one half in the custodial seeti on of the chronic disease hospital.

7. Mast of the patients expresses satisfaction with their discharge plans but were not facing the reality of their aituations. A plan that may have been considered foasible in the hospital often did not wark out at home. One third planned to return to work but only a few were able to do so. A very few had thought of utilizing community resources other than the hospital and the relief agencies either because of lack of knowledge about these resourees, unwillingness to leare the family setting, or because of the stigna attached to some of these facilities, particularly the public Institutions. Patients who hed considered institutional care had not followed through bebecause they had either made other plans or because they were not eligible for such cere. Twelve percent of patients (not including the paychiatrie) made some adjustment in the form of plans to drop all activities and convalesce at home, enter an institution, or trensfer from one institution to gnother.

8. The patientes own home is the mast desirable resource if the home, physically and otherwise is suited to meet the needs of the sick individual. The patients own home was considered suitable for his 
cere in four fifths of cases. The community can help to render the patient's home more suitable by providing elinle, visiting physic ian, nursing, and housekeoping alde services, and through adequate public assistance. Vocational rehabilitation and seltered workshops help the person to meintain his independence by offering job training and placement in work suited to the person's physical limitations. Foster hanes are a desirable substitute for the patient's own home. Louisville offers adequate medical services: clinics, visiting physleians, and nursing. Three of the above mentioned programs have, however, not been dereloped or are inadequate to meet the need: Houseke日ping aides, public assistance, and fos ter home placement. oultable foster homes have been difficult to find for well children, let alone sick children and the aged.

9. The re are some 23 privately operated nursing homes in Louisville, ell licensed under the law which went into erfect in July, 1944. Great strides have been made in improving the standards of the homes but they still are not the best plan for the chronically 1ll. Overcromded, they give inadequate medical attention, and are too expensive for the everage individual especially the chronic who has had his resources depleted by his illness. Subsidized nursing homes, in inincreased numbers, to accomodate the public ass istance client, will sare the community the high cost of institutional care in some cases. 10. The two city-county institutions are being used almost exclusirely for the chronically ill, with the Home for the Aged and Infirm offering en entirely different type of medical care than the Jefferson County Home for the Aged. There has been so much reluctance about providing the Home for the Aged and Infprm with a much needed elevator and ot her improrements that it seems improbable that the Home would 
over meet the stondarde necessary to becoming a chronic hospital. Converted amshouses are never suited to giving class $A$ and $B$ medical care, and the only possible use recommended far the Home for the Aged and Infirm is as the custodial section the chronic dis ease hospital.

11. The benerolent homes serre aseful function, but too, are limited in scope. There are walt ing lists of several hundred names at some of these homes. There are several additional hundreds who would like to enter but tho are not el igible.

12. Kings Daughters Home for Incurabl es would render a service to the community by striking out the letter half of its name.

13. The crippled childrens program 1 s providing necessary treatment, appliances, hospitalization, but facilit les for two large groups are still lacking; spastics and rheumatic fever patients. Great efforta should be expended to provide the minimum facilities require in order to qualify far foderal aid for the operation of such programs.

14. Facilities are badly needed for adult cripples who are by passed by both Vocational Rehabiliation and the Crippled Childrens Commission programs. Long term hospitalization is often of benefit and should not be denied these patients. A proposed chronic hospital would provide the environment, technicel equipment, and the skilled speetalists to halp these patients.

15. The problem of Negroes affected by chrontc disease is serious. Mifty percent of cases chonic illness were anong Negroes, yet they form only $15 \%$ of the Louisville population, and have even a analler share of community resources devoted to meeting their needs. 
Negro chilaren have no place to convalesce if the ir own homes are unsultable, except poss 1ble foster homes. A much larger proportion of Negro than White petients hed cardiac and gnocological conditions, and were unskilled and domestic laborers.

16. A chronic disease hospital in Louisville would offer the best solution to the problem of orercrowing in Louisville Ceneral Hosp1tal and the expensive cost of maintaining a chronic patient in a hospital for the acutely ill, as well as offering the best plen of medical care for the chronically ill. In the chronic hospital all level s of treatment should be integrated for the most efficient operation and far the benefit of thepetient by cansidering his needs at rarious points in his 1llness.

17. Chronic hospital care is indicated for those patients who cannot be properly cared for in their own homes, those who do not benefit by clinic visits for one reason or another, those who cannot receive proper medical care at a nursing home, city, or endowed institution, as for example, the cancer petient, those wo are not eligible for nursing home or institutional care or who would ot herwise be eligible but for whom no vacancy exists, and those for whon no proper resource exists.

18. Louisville hes for meny years considered adding a chronic hospital to the present hospital set up, with most of the thinking centered about the idee of converting Louisville Ceneral Hospital into a chronic hospital and erecting a new hospital to accomodate the acuteIy sick and injured. sstimates of needed capacity range from 400 to 1000 beds.

19. A good chronic hos pital should contain all of the modern facilitiea 
of the general hospital, in addition to various conveniences and conforts in a homelike atmosphere to moke the patient's long stay as pleasant as possible. Adequate nursing staff, programs of physical therapy and occupational therapy, and mical social service should be provided. The petients in the present study were apparently not utilizing physical therapy and occupational therapy facilities, but three fifths of the patients were known to a social worker tho was helping them to moke oconomic, social, and physical adjustments to their handicaps.

20. A progrem of prevention for wich the community takes primary responsibility, affects a great saving in money and human suffering. Public expenditures for improving public heal th results in ultimate public serings. Chronic illness is a drain upon an individual's morale, vitality, and productireness, and upon comnunity resources. 21. The federal government enters the picture through its social Security programs, and proposed measures of grants for hospital construction, expansion of social security benefits to inmated of public institutions and to proride disability insurance, and through a plan of national health insurance. 
BIELIOGRAPHY 


\section{BOOKS}

Bachmey er, Arthur $C_{\text {. }}$ and Hartman, Gerhard. (ed.). The Hospital In Modern Soclety. The Commonwealt h Fund, New York; 1944

Boas, Hest P. The Uns een Plague Chronic Disease. J.J. Augus tine Publisher, Ner York; 1940.

Hall, Fred S. and Ellis, Mabel B. (ed.). Soc lal Work Year Book. Ruasell Sage Foundati on, New York; 1929, 1933, 1935, 1941.

Jarret, Mary C. Chronic Dllness in Ner York City. 2 vols. Columbia Uni vers it $\bar{y}$ Press, 1933.

Margolis, H.M. Diagnosis And Treatment of Arthritis and Allied DisDederg. Peul B. Hoeber, Inc., New York; 1941.

\section{PUBLIC DOCUNEWTSS}

Compilation of the soc ial Security Laws. Social Security Board. Washington, D.C.; 1941

Interdep artmentel Committee to Coordinate Health and Welfere Activities. The Nation's Heal th. Nashington, D.C.; 1939.

Interdepartmental Comittee To Coordinate Health and Welfare Activities. Proceedinge National Health Conference. Washington, D.C.;1938.

Louisville And Jeffers on County Board of Health. Rules And Regulations coverning Nursing Homes. Loulsville; July, 1944.

\section{REPORTS}

Bradley, F.R. and Raper, R.E. Prel Iminery Loulsville Area Hospital SurTey Made For Loutsजille Area Deralopment Association. St. Iouis; November, 1945.

Britten, R.H., Collins, S.D., and Fitzgerald, J.S. The National Falth Survey: some general findings as to Disease, Accidents and Impalrments in Urban Areas. Vol.55, No.11. Govermment Printing office, Weshington, D.C.; 1940.

City of Louisville. Annual Report of Department of Welfare; for Fical Year ended June 30, 1944. Loulsville; June, 1944.

Counctl of Social Agencies of the Louisville Community Chest. Bulletin . 
No.14. Oetober 23, 1937.

Federal Security Agency. Annual Report of the Office of Jocational Rehabilitation 1944 Government Printing Office, Nashington, D.C. ; 1844.

Jarret, Mery C. Housekeeping Service For Home Care or Chronic Pet ient s: Report of a FPA Project in New York City. NeT York; December, 1938.

Karplnas, Bermard D. The Phyeically Handicapped. Vol.58, No.43. Gor ermment Printing offie $\theta$, Washington, D.C.; 1943.

Kentucky Crippled Children Comission. Blennial Reports: For 1939, 1941, 1943, 1945. Loulaville.

Louisville And Jefferson County Health Departmont. Annual Report 1944 . Loulsville; 1944.

Loulsville Area Development Association. Planning $f a$ the Louispille Area. No.5 Louisville; March 1945.

Montefiore Digeat, Annual Report for 1935-1939, 1940, 1941. New York.

State Department of Health. Information on Publ ic Health Nursing. Lou1sville; 1944.

State Department of Health. Vital Statisties Report 1944. Vol.xvii, No.2, Louisville; 1944 .

Perrot, G.S., Tibbits, C. and Britten, R.H. The Nati onal Hoelth Surrey: Scope and hiethod of the Nationwide Canrass of Sickness in relation to it's Social and Economic Setting, Vol.54, No.37, Government Printing office, Washington, D.C.; 1939.

Public Welfare Council. Need For a State Inf irmary For The Care And Preatment of Aged, Inf irm And Chronically IIl Persons. Hartford; 1944.

\section{ARTICLES}

Barker, Lerrellyn F. "Onthe Care or The Aged", Canadian Hospital, Way, 1941, pp.31-38.

Bartlett, Harriet $\mathrm{k}_{0}$ "motional Hements In Illness: Responsibilities of The social Worker," Femily, Vol.5xi, No.2, April, 1940, pp.39-47.

Bidile, Cornelius i. Whe Individual In Relation To A Medical Care Program, NPenily, Vol..xxv, No.4, June, 1941, pp.104-111. 
Boas, Ernest P. "The Care Of The Chronically Ill, "Reprinted From The Proeedings of Nati onal conference uf social Workere, Columbia University Prees, NeT York; 1939.

2"The Chrontcally Sick, "Amerte an Joumal of Nursing, Vol. Ixxvii, Ho.2, Pobruary, 1937.

¿. "A Commity Program For The Care or The Chronie Sick," reprinted fram Eospitals, Februery, 1936.

- "Convalesecence And Chronic Ilness," Reprinted Irom Proceedings of the Conference Held Under the Aupices of The Committee on Publ ic Hoalt h hoports of Nor York Academy of Hedic ine Ner York; Nor enber, 1939.

et al Wursing Service in Hos pitals For Chronic il sease, Mhodern Hospitala, Vol.2xi, No.2, August, 1925, p.IA5.

-ot al "Present Institutional Pacilities for care of Chronic Disease," Modem Hoopitals, Vol.2xxi, No.1, July, 1923, p.I.

Mluestone, B.M. "Adminstrative Axioms," Modom Hospltals, Vol.1rv, No.5, November, 1945, p.77.

- "The Fmergence of The Chronic Patient," Journal American Modical Association, Vol.cxn111, No.6, Netober, 1943, p.374.

- "Chronic Disease Patients, Planning For The ir Care, "Modern Hogpital, Vol.11v, No. I, January, 1940, p.66.

Buell, Bradley. "From Yesterday To Tomorrow, "Survey Midmonthly, Vol. Inxxi, No. 10, Ootober, 1945, pp.253, 254.

Butler, Charles am Franklin, I.M. "Chronic Disease Patients, Fousing Then Large Scale," Modern Hospital, Vol.11v, No.1, January, $1940, \mathrm{pp} \cdot 67-73$.

Butler, Charles and Golub, J.J. "Home For Aged And Infirm Hebrew, New Hospital Wing," Hospitals, Decenber, 1942,pp.49-54.

Clay, Charlea L. "Keoping Them Contented," Modern Hos pital Vol, IIV, No.1, Jamary, 1940, pp.77-79.

cookerill, Heanor. "The Soc ial Worker Looks At Cancer," Family, Vol.svi1, No.10, February, 1937, pp.326-329.

Daxter, 且izabeth H. NNew Concepts In Case Work Practise With the Aged," Framily, Vol.xx. No.6, 1939, pp.171-176.

Domes, Jean, "Chronic Disease Among Mtdale And Old Age Persons," Reprinted From The Millibank Fund Quarterly, Vol.xix, No.1, January, 1941 .

Erickson, Don J. and Krusen, Frank J. "Physical Therapy Comes To The 
11d of The Aged," Moderm Haspital, Vol. 1x11, No.5, May, 1944, pp. 88-92.

Fairfleld, Letit 1a" "Care of The Chronic Sick," Lencet, October, 1943, pp.455-457.

Frans, Louis, "Prov iding Institutionel Care For Recipients of Public Assis tence," Public Felfare, Vol.111, No. 11, Norember, 1945, Dp. 248-253.

F1tzetumons, Margeret, "Treatment of Problems of Dependency Related To Permen ent Physical Hendicap, "Frmily, Volxxili, No.9, Septamber, $1943, \mathrm{pp} .329-336$.

Gordon, Irckka. "Treatment of Problems of Dependency Related To Illness," Ianily, Vol.xxi11, No.6, June, 1943, pp.210-218.

Gere, George. "A Constructive Contribution To the Comfort of The Aged," Reprinted From kodern Ho spital, September, 1945.

Hamilton, Gardon. "Case Work In Old Aged Assistance," Family, Vol.xvi il No.10, February, 1938,pp.327-333.

Helser, Karl F. "The Problem of Chronic Illness In Connecticut," Connecticut State Medical Journal, February, 1944,pp.79-82.

"How Should Private Nursing Homes Far Aged Be Regulated, "Hospital lenagement, July, 1945, pp.69-70.

"The Hill-Burt on B1Il," Amexican Journal of Public Health, Vol.xxxr, No.4, April, 1945, p.380.

Goldwater, S.D. "The Hoopitalization of The Chronleally IIl," Printed By Committee On Ohronic InIness of Welfare Council of Ner York C1ty, April, 1935 .

Jarret Mary C. "The Care of the Chronically IIl," Hos pital Survey of New York, Vol,11, Chop.xi, 1937, pp.642-700.

Jensen, Andeen C. "Chronic Disease Patients Hous ing Them Small Scale," Modern Hospital, Vol.11v, No. 1, Jenuary, 1940, pp.74-75. " "seficlent Nursing of Chronic Illness," Modern Hospital, Vol. 1xi11, No. 1, July, 1944, pp.57-59.

Wisel,albert Q. Wrgently Needed A National Health Fund," Mocall's, February, 1946, pp.133-138.

Marsh, Edith L. "The Care of The Chronically Inl At The Cuyahoga County Nursing Home," American Journal of Nursing, Vol.41, No.2, Fobruary, 1941, pp.161-166.

Mas on Clifford V. "Iet's Keep the old Gray Mare In Harness, Modem 
Fosp1tal, Vol,1xi1, No.2, February, 1944, pp.82-84.

Meclurk in, Heanor. "Chronic Disease From the Patients Point of Vier," Modern Hospital, Vol.1xv, No.5, November, 1945,pp.78 $-79$.

Potter, Mlen C. "Joint Federal-State Aid For Chrinics Held Essent1el," Modical Economi cs, Decomber, 1940, pp.87-88.

- In Future Plang Chronic Disease Hust Have A Place; Ner Jersey Starts," Hosp1tals, May, 1944,pp.33-36.

- et al." "gtater Face New Problems In Increasea Demands of Chronic Care," Hos pit als, Warch, 1945, pp.45-48.

Rasenfleld, Isadore. "The Fruit of Reasearch," Modern Hospital, Vol.48, No.3. March, $1937, \mathrm{pp} .58-64$.

- "Care of The Chronie Sick," Bospitals, Norember, 1944,pp.5053.

Seogal, Darid. "The Problem of Chronic Disease, "Hosp 1tals, March, 1938,pp.32-34.

Stowell, Kenneth $\mathrm{K}$. "Publ ic Health-Your Opportunity," Architectural Record, Vol.97, No.4, Way, 1945, p.69.

Hagner, Margaret. "Mhrsing Hames Call For Rigid supervision," Hospitals, Warch, 1945, pp.52-56.

Walker, Bugene and Dixon, Jennie. "Chron ic Disease Ward 10 yYears After," Modern Howital, Vol.64, No.6, pp.55-62.

Warren Marjory W. "Care of Chronic Sict, "British Medical Jourmal, Dec ember, 1943, pp.822-823.

Weil, Julius. "The Aged III Need A Specialized Staff," Hospitals, March, 1945.

\section{UNPUBLISHEW MATERIAL}

Bechmejer, Arthur C. "Confidential Report Preliminary Draft To Dr. John phair, Commissioner of Health," January, 1946.

Caswell, Crace B. "Convalescent Care In Loulsville, Kentueky," Unpublished Masters thesis, Divis ion of social Adminis$t$ ion, Universi ty of Loulgville, Oetober, 1943.

Chendler, Doris. "Notes On Chronic Disease," Council of Social Agencies, April, 1944. 
Haines, Anna J. "Chronic humeraticn," Lou is ville Heal th Council, 1937.

Health and Fenily and Child Felfare Councils of the Community Chest, "Study of The Provision For Chronic And Incurable Petients," Iouisville, 1927.

Iipetz, Irving. "The Louisville Home For The Aged And Infirm, A Study Of An Institution In Transition, WOnpublished Master's Thesis, Division of Social Idministration, University of Louisville, 19

Phelps, Evelyn. Memorandum To Mr. Falton on Need For More Beds For Chronie And Convalescent Patients," Jume, 1945.

Report of conmittee on Survey of the Operation of The Jefferson County Howe For The Aged," November, 1845.

Tyylor, Esther." Nemo To Bxecutives of Social Agencies On Kings Deughters Home For Incurables," February, 1946.

Tilliamson, Mary T. "A His tory of The Council of Social Agencies of Louisville, Kentuc ky," Unpubl is hod Masters Thesis, firision of Social Administration, University of Louisville, November, 1943.

\section{NEWSPAPER ARTICLES}

Courd er Journal:

Norember 11, 1945

Novenber 18,1945

Jemuary 20,1946

Fobruary 21, 1946

April 5, 1946

Apr11 7, 1946

April 12, 1846

April 14, 1946

Louisville TImes :

January 18, 1946

February 5, 1946

April 10, 1946

April 16, 1846 
APPENDIX I 
Na in household: EOUSING: Alone Chil dren :

WI th relatires ' W1 th friends Boarding

OCOUPATION:

INCOME: Earnings

Serings

Insurance

Army-Navy (pay allotment)

Compensation

Social Agency

Other

Onknown

Date of adnission:

On Ward at Present?

Prori ous Admis sions
Dete of Di scharge:

Datos of Discharge:

Other Hospltals:

Nursing Homes:

Institutions :

Darati on of Iliness (Date first became 11l)

Diagnosis: 1 . Prot si onal?

2. Confirmed?
Last imployed:

No. of $100 \mathrm{~ms}$

Roon to salf?

Sleep alone?

CONDITION: Ambulatory

Partially Ambulatory (crutches, cane, confined indoors)

Theelchair

Bedridden

Prognos is (if kmown)

Treatment: Special X-rays Operations :

Tests (not routine blood)

Medicine

Special Diet

Physiotherapy

Ocoupational Therapy

CLINICS ATPENDED:

Last clinic attended Regular Occasi onal

Recommendations (chart \& Interviens with Modical Staff)

) 1. Putient requires medical care far diagnos is \& treatment.

(2. Pationt requires chlefly silled nursing care.

) 3. Patient requires only custodial care.

( I. Patient needs to continue at I duisvillo General Hospital for medical \& nursing care. Approximate period 
(2. Patlent may be cared for at hone

) Littlo nursing care

( Intensive nursing care

)) Clinie

( 3 . Patient needs custodial care (general nursing care and supervistion

In your opinion if Louisville had a chronic hcopital would that be desirable for patient?

RNOWN TO SOCIAL SERVICB:

PATIENTS IN HOSP ITAL:

Plans up on Discharge

Probablo

What pationt would desire

If home - anyone to help out?

PATIENTS AT HONE:

Attending clinic? Frequency?

V.N.A.

other nursing?

Soneone to help out?

Private physician

Take medieine

Has patient ap plied considered__nurelng hame, Home for Aged and Infirm, Cutreh home?

If gplied thy didn't go?

If available would patient prefer any of the following to present arrangement?

Home for Aged and Infirm

Private nursing hane

Church - benerol ent hane

Better nursing at home

Chronic Ho spital

Any other

COMARENS: 
APPENDIX II 
MONTEFIORE HOSPIT:I AND RLE CTRONIC DISTASE

HOSPITAL NELFARE ISLNDD

MONPEFINRE HOSPITAI

Fifteen percent of the petients in wontefiore Hospital are custodial patients housed in the schiff pavilion. In adaition to the city institution, Nontefiore Hos pital operates a country santtorium of 230 beds for tuberculos is at Bedford Hills, New York, thirty miles from the main hospital, and the Wack Nemorial, a summer vacation home for cardiac clinic children. The liack liemorial is Ossining, New York, overlooking the Fudson River, acconodates 110 children during fifteen weeks fram June through September. Montefiore also has a clinic for the follow up of discharged patients, The twelve mein buildings of the hospitel occupy seven squarebloks. In spite of a very high occupancy rate of about 99 percent throughout the year, the hospital has a list of waiting patients wich everages 200 names.

Montefiore Hospitel for Chronic Diseases in New York is the best representative of good chronic planning in the voluntary field. It has a total bed capacity of 944 beds including the separate custodial section and Tuberculosis Sanitarium. To provide a well rounded service $f \boldsymbol{x}$ petients, fontefiore hospltal has its orn school for 30 children petients, central radio system which provides radio facilities for all of the patients, a 22,000 volume library, flower gardens, and printing shop, sewing and weaving rooms, and carpenters shop as part of the rehabilitation program aimed at training chronic patients to be at least partially self supporting when they leave the hosp 1tal. Noving pictures are shown bi-weekly.

Beginning as a custodial institution in 1884, Montefiore Hospital has developed into on outstanding center for research. It has 
four large clinical divisions; the surgical division the medical division, the neurological division, and the division of pulmonary diseases. There is also a laboratory division, and in addition each of the four main divisions has its own laboratory for research. About twelve percent of ell beds are used for private patients, and four and one half percent of all beds are occupled by children.l

THE TOSPITAL FOR C RON IS DISELSE ON WELPARE ISLAND

Agitation for planning chronic facilities began in April, 1935 when Dr. Coldwater, Commissioner of the Department of Fुospitals, sponsored an auxiliary which came to be known as the Research Council of the Department of Hospitals. This Council, functioning through a scientific committee representing five medical schools and the Department of Hospitals, had for its aims the fostering of medical research in the Department of Hospitals and the promotion of a clinical division to be known as the Research Division of Chronic Diseases. In May 1936 a building cansisting of a sixty bed hospital and associated research laborataries was dedicated as temporary headquarters for the work of the Research Division. It was planned thet permanent quarters would be located in the new welfare hospital to be ready for occupancy' in 1939.

The chronic disease hospital acturlly came about as a result of the work of mony indiraduals and agencies under the leadership of the Committee on Chronic Illness of the Welfare Council of New York city, wich was established following the publication of the findings of the 1928 survey. This body has a its objectives:

$1_{\text {Montefiore Digest. Five year report-1935-1939; annual report }}$ for 1940 . 
1-The creation of new attitudes toward chronic lliness through public education.

2-Fixing of responsibility for the care of the dependent chronically ill upon the city government.

3-Seeking of a definition of policies and responsibilities in regard to the chronic sick by the voluntary agencies with a view to more effective use and development of their facilities.

4-The bringing about in certain fields of chronic disease that are not already organized, more adequate coordination and development ment of services for prevention and care of chronic illness.

5-Offering of consultation service on problems connected with the prevention and care of chronic illness.

This committee pioneered in directing public welfare opinion to the need for mobilizing its resources against the destructive forces of chronic dis ease.

Welfare Island (the once not orious Blackwell 's Isl and) was the slte of the 1000 bed hospital. Welfare Isl and, hitherto shared by the Department of Hospital $s$ and the Department of Corrections, becane total hospital territory. This haspital is unique in its general plan, which is strictly functional. Built on a section of the island 500 feet in width, the hospital site is nearly 1200 feet long and consists of four ward buildings, each four stories high, an administrative and treatment building also four stories, and a three story laboratory building, all of these connected by a two story corridar running north and south. Corridors are twelve feet wide so that they may be used for additional sun porches, and the roofs at the third floor level are used as terraces. Five foot 
balconies are carried acros the south front of all wards, and eleven foot balconies extend acros $\mathrm{s}$ the end of the 24 bed wards. On the first floor a terrace 20 feet wide extends across the en tire south front of each pavilion with easy ramps dom to the scound. There is a 24 bed ward and an 18 bed ward in addition to four isolation rooms on every floor, but these are divided into smaller units by partitions. The 24 bed ward is divided into six units of four beds each, and the 18 bed ward in to three units of six beds each.1

All sorts of minor conveniences for the patients were thought of such as special light ing for reading in bed. The problems of cisculation, control, orientation, view, and amole ground snace, were given careful consideration. To achieve the maximum sun exposure, best $v i e w$, and best utilization of narrọ space, the hospital departed from the traditional experience that has influenced the design of most hospitals, and constructed ward buildings of chevron shape. It is functional planning at its best. This is one of three chronic hospitals located on Welfare Island. The others are coldwater Nemorial, of 1800 beds offering class A care, and City Hone, offering C care. The Chronic Di sease llos pital of fers type B care. New York $c$ it $y$ in 1944 offered $s$ ome 3550 municipal beds for the chronically ill. It was expected that when the entire program of construction for the chronic sick was carried out, voluntary beis as Well as municipelly provided New York city would offer 10,000

IButler, Charles, and Franklin, L.M., "Chronic Disease Patients Housing them, Large scale", lodern Hospital, vol.54, No.1, Jonuary, 1940. pp.67-73 
Name

Goldwater Memorial Hospital

Kings County Hospital-

Chronic Disease Pavilion

Chronic Dis ease Hospital

\#elfare Island

City Home-Welfare Island

Farm Colony-Staten Island
No. of beds

1800

750

1000

2000

3000
Kind of care

$\Delta$

$A$ and $B$ combined

B

C

C

Tot al

8550

to 10,500 beds for chronics, or about 1.4 beds per thousand population. It was estimated that this would be less than one half of actual need. In a Cleveland survey a conservative estimate was 3.3 beds needed per thousand population, and that the number that should be provided for in class A hospitals should be from one third to one fourth of the total beds. 1

1 Rosenfield, Isadore, Ib1d. pp.52-53. 
APPENDIX IIII 


\section{Dear}

I am doing a study of some of the people who were patients at Louisville Ceneral Hos pital during the month of Fobruary 1946, to determine the kind of care that these petients received, and what sort of plans they made after returning to their homes. I understand that jou were at the hoppital during this time. I would greatly appreciate it if you would answer the following questions for me by putting a check next to the epproporlate answer, by filling in the desired information, or by miting a brief explanation when you feel it is necessary.

Number of people living in your house-hold wi th you

Number of living children

\section{Their Ages}

Do you live

Alone
With relatives
Wi th friends
Board

How many rooms do you occupy?

Do you have a room to yoursele?

Do you eleep al one?

That is your occupation?

When were you last emplayed?

What is the source of your incane

rarnings

Sarings

Insurance

Army-Nary

Compensation

Pension

Tol fare agency

Which one

other

Were you ever at any other hospital?

Were you everrat any Mursting Home?

Were you ever at eny other Institution? 
What is your condition--do you walk about without help?

Use crutches or a cane or a wheelchalr?

Are you confined to your bed?

Do you attend any clinies at Louistille General Hospital?

Which one? How of ten?

Doep a nurse from Vis 1ting Nurse Assoclation or other nursing agency visit you?

Do you have someone at home to halp out?

Are you being treated by a private physician?

Do you take medicine?

Have you ever pplied or considered going to

a private nursing home?

Home for the aged and infirm?

Church home?

If you did spply why didn't you go?

If any of the following were arailable would you prefer any of the following to your present arrangement, (Please check the one that you Tould prefer, if any)

Home far the Aged and Infirm

A private nurs ing home

Church Home

Better nursing at home

Housekeeping help

A chronic hospital

Any other

I enclosing a stamped addressed envelop for your convenience in mailing this questionnatre back to me, and would appreclate if you would return it as soon as possible. I hope that you will feel free to reply as honestly as possible because your answers will be tabulated along with many others, and no names will be used in the $f$ in is hed study.

Thanking you far your cooperation, I am,

Sincerely yours, 


\section{APPENDIX IV}

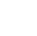


LOUISVIIIE AND JEFFERSON COUNTY HEALTE DEPARTMENT

\author{
LOUISVILLE, KENTUCKY \\ APPLICATION FOR PERUIT TO OPERATE \\ A NURSING HONE
}

The undersigned hereby makes application for a permit to operate a nursing hone for patients to be issued to address sub ject to the rules and regulation governing Nuraing Home, adopted July 20 th, 1944.

The maxium number of patient $s$ to be cared for will not exceed - Ages between - Sex - Color - List number of patients now being cared for

Have you read the rules and regulation governing Nursing Home?

Does your home, in your opinion, meet all the requirments outIined in the rules and regulations? - Ana do you have a person in charge with some hospital training or satisfactory experience as a practical nurse? - If not, explain

If so, give dates and detalls

List neme and address of three refrences on opposite side of form. A fee of two dollers must accompany this application to partially cover the expense of lssuing permit. Checks should be made payable to Lou is ville and Jefferson County Health Department.

\title{
Approved
}

Disapproved

By

Slgnature of Applicant.

Date 